The Russian Second

Generation in Tallinn

and Kohtla-Järve

The TIES Study in Estonia

RAIVO VETIK \& JELENA HELEMÄE (EDS.)

$T$ I $E$ 
The Russian Second Generation in Tallinn and Kohtla-Järve 


\section{IMISCOE \\ International Migration, Integration and Social Cohesion in Europe}

The IMISCOE Research Network unites researchers from, at present, 28 institutes specialising in studies of international migration, integration and social cohesion in Europe. What began in 2004 as a Network of Excellence sponsored by the Sixth Framework Programme of the European Commission has become, as of April 2009, an independent self-funding endeavour open to qualified researchers and research institutes worldwide. From the start, IMISCOE has promoted integrated, multidisciplinary and globally comparative research led by scholars from various branches of the economic and social sciences, the humanities and law. The Network furthers existing studies and pioneers new scholarship on migration and migrant integration. Encouraging innovative lines of inquiry key to European policymaking and governance is also a priority.

The IMISCOE-Amsterdam University Press Series makes the Network's findings and results available to researchers, policymakers and practitioners, the media and other interested stakeholders. High-quality manuscripts authored by Network members and cooperating partners are evaluated by external peer reviews and the IMISCOE Editorial Committee. The Committee comprises the following members:

Tiziana Caponio, Department of Political Studies, University of Turin / Forum for International and European Research on Immigration (FIERI), Turin, Italy

Michael Collyer, Sussex Centre for Migration Research (SCMR), University of Sussex, United Kingdom

Agata Górny, Centre of Migration Research (CMR) / Faculty of Economic Sciences, University of Warsaw, Poland

Rosita Fibbi, Swiss Forum for Migration and Population Studies (SFM), University of Neuchâtel / Institute of Social Sciences, University of Lausanne, Switzerland

Albert Kraler, International Centre for Migration Policy Development (ICMPD), Vienna, Austria

Leo Lucassen, Institute of History, Leiden University, The Netherlands

Jorge Malheiros, Centre of Geographical Studies (CEG), University of Lisbon, Portugal

Marco Martiniello, National Fund for Scientific Research (FNRS), Brussels / Center for Ethnic and Migration Studies (CEDEM), University of Liège, Belgium

Patrick Simon, National Demographic Institute (INED), Paris, France

Miri Song, School of Social Policy and Sociology, University of Kent, United Kingdom

More information and how to join the Network can be found at www.imiscoe.org. 


\title{
The Russian Second Generation in Tallinn and Kohtla-Järve
}

\author{
The TIES Study in Estonia
}

edited by Raivo Vetik and Jelena Helemäe

IMISCOE Reports

AMSTERDAM UNiversity PRESS 
TIES: The Integration of the European Second Generation

TIES is a collaborative and comparative research project on the descendants of immigrants from Turkey, the former Yugoslavia and Morocco who live across eight European countries: Austria, Belgium, France, Germany, the Netherlands, Spain, Sweden and Switzerland. This book is a research report on the associated TIES project in Estonia, which investigates the position of second-generation Russians. Reports on the other participating countries will follow.

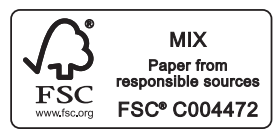

Cover design: Studio Jan de Boer BNo, Amsterdam Layout: The DocWorkers, Almere

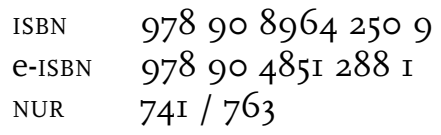

(C) Raivo Vetik and Jelena Helemäe / Amsterdam University Press, Amsterdam 20II

All rights reserved. Without limiting the rights under copyright reserved above, no part of this book may be reproduced, stored in or introduced into a retrieval system, or transmitted, in any form or by any means (electronic, mechanical, photocopying, recording or otherwise) without the written permission of both the copyright owners and the authors of the book. 


\section{Table of contents}

$\begin{array}{ll}\text { Preface } & 7\end{array}$

List of tables, figures and chapter appendices 9

$\begin{array}{ll}\text { I Introduction } & 13\end{array}$

Raivo Vetik and Jelena Helemäe

Nastja Sokolova

3 Integration policies

Raivo Vetik

4 Ethnic inequalities in education

59

Kristina Lindemann and Ellu Saar

5 Explaining different returns from human capital in the labour market

Kristina Lindemann

6 Income inequality

Rein Vöörmann and Jelena Helemäe

$7 \quad$ Housing conditions and

neighbourhood satisfaction

Liis Ojamäe and Katrin Paadam

8 Contact and crisis in interethnic relations

Jennie Schulze

Leeni Hansson

IO Sense of belonging to Estonia

Gerli Nimmerfeldt 
II Conclusions

Raivo Vetik and Jelena Helemäe

Appendix

List of contributors 


\section{Preface}

The integration of the Russian-speaking minority in Estonia has been on the research agenda as a case study as well as an issue worthy of comparison since Estonia regained independence in I99I. There are numerous books and articles devoted to the subject, discussing various aspects of integration processes in the society as well as integration policies carried out by the authorities. However, so far there have been very few studies on the integration of second-generation Russians in Estonia. Our purpose here is to fill this gap in the field - or at least to start doing so.

The data for this volume come mostly from research undertaken as a part of the international comparative project The Integration of the European Second Generation (TIES), led by Maurice Crul and Jens Schneider at the University of Amsterdam. The Estonian team joined TIES as an affiliated partner in 2006 by contributing to the formulation of several sections of the TIES survey and by proposing another perspective: comparison of the Russian second generation to the other immigrant groups already included in the project. The Estonian case study presented in this report followed the theoretical lines of the general TIES project, utilising principal features of the research design, including concepts and their definitions as well as the indicators for those concepts.

Our research team consisted of scholars and students at the Institute of International and Social Studies at Tallinn University in Tallinn, Estonia. Represented are three different departments at the institute: the department of social stratification, the department of lifestyles research and the department of ethnosociology. As coordinator of the project, I would like to thank all the team members for the time and effort they devoted to the project and for their excellent contribution to this volume.

I am grateful for the opportunity the Estonian team had to cooperate with colleagues from the eight European countries that are also part of TIES. We gained a lot from participating in various TIES conferences and workshops during the project, which also proved very helpful in preparing this report. Our hope is that in the future it will be possible to enrich the case study we carried out with studies comparing 
Russians in Estonia and the other migrant groups represented in TIES. We would hope such comparisons would prove useful for both the sake of theoretical advancement and policymaking.

The Estonian TIES project and subsequent preparation of this publication were supported by a number of institutions in Estonia and abroad. Our fieldwork in Tallinn and Kohtla-Järve and Jõhvi was carried out by the polling company Faktum \& Ariko and financed by a grant from the Research Fund of Tallinn University. In different stages of the project, we were supported by several grants from the Bureau of the Ministry of Population of Estonia. Completion of the report was supported by grant number 7720 from the Estonian Science Foundation.

I would like to thank all our collaborators and sponsors for their help and kindness along the way. I am grateful to our TIES colleagues across Europe for their constant support and great work, all done in the spirit of cooperation. Special thanks goes to Maurice Crul and Jens Schneider for inviting the Estonian team into the TIES network and for their friendly but firm leadership throughout the project. Last, but not least, I would like to thank Tiia Falk for English language editing of the chapters in this volume and Christine Waslander and Karina Hof for helping prepare the manuscript for publication.

We would like this volume on the integration of second-generation Russians in Estonia to reach out not only to scholars in other countries, but also to the general public, policymakers and relevant actors in the field in Estonia. It is our hope that the findings of this report will generate not only academic debates, but also encourage Estonian stakeholders to take concrete steps to make our country a better place to live.

Raivo Vetik

Coordinator of the TIES project in Estonia 


\section{List of tables, figures and chapter appendices}

\section{Tables}

Table 2.I Change in population in Estonia during the Soviet period by ethnic group

Table 2.2 Share of Russians in population (in \%) 33

Table 2.3 Place of birth and parents' place of birth (in \%) 34

Table 2.4 Distribution of citizenship (in \%) 34

Table 2.5 Gender distribution by city of residence and ethnic group in TIES project (in \%) 35

Table 2.6 Parents' country of birth in TIES project (in \%) 36

Table 2.7 Distribution of citizenship by city of residence among Russians in TIES project (in \%) 36

Table 2.8 Responses to question concerning parents' citizenship in TIES project (in \%)

Table 4.I Educational level of different ethnic groups in I989 and 2000 (in \%)

Table 4.2 Proportion of studying youth according to age group and ethnic group in Tallinn and in Estonia (in \%)

Table 4.3 Educational composition of parental and second generation (in \%)

Table 4.4 Transition to general secondary education (versus other types of secondary education): Logistic regression models

Table 4.5 Transition to higher education and finishing studies (versus not continuing studies in higher education after attainment of secondary education or entering to higher education, but not finishing studies): Logistic regression models

Table 5.I Occupational status of Estonians and non-Estonians in 1989 , I994 and 2008 (in \%)

Table 5.2 Occupational status of employed persons in Tallinn and towns of Ida-Virumaa County (in \%)

Table 5.3 Estonian language writing skills by other type of country-specific human capital (in \%) 
Table 5.4 Access to managerial, professional and specialist positions, logistic regression model, $\mathrm{N}=646$

Table 5.5 Second-generation Russians' access to managerial, professional and specialist positions, logistic regression model, $\mathrm{N}=294$

Table 5.6 Odds of Estonians and Russians with different language skills and studies achieving managerial, professional and specialist positions, logistic regression models

Table 6.I Employment and studies by parents' employment, ethnicity and age (in \%)

Table 6.2 Non-studying respondents' employment, benefits and parental support as sources of income by living arrangement and ethnicity (in \%)

Table 6.3 Monthly income of non-studying youth by ethnic group and gender (in \%)

Table 6.4 Belonging to the highly paid segment of working youth, odd ratios, logistic regression model, $\mathrm{N}=462$

Table 6.5 Country-specific human capital as a factor of belonging to highly paid employed: Gross and net effects

Table 7.I Dwelling types of respondents residing on their own or in parental households (in \%)

Table 7.2 Tenure status of respondents residing on their own and in parental households (in \%)

Table 7.3 Ratio of the number of household members to the number of rooms in a dwelling

Table 7.4 Access to spaciousness in households residing on their own: Logistic regression models

Table 7.5 Access to spaciousness in parental households: Logistic regression models

Table 7.6 Estimations on the ethnic composition of the neighbourhood (in \%)

Table 7.7 Neighbourhood satisfaction (own households): Logistic regression models

Table 8.I Multinomial logistic regression model I

Table 8.2 Multinomial logistic regression model 2

Table 8.3 Multinomial logistic regression model 3

Table 8.4 Multinomial logistic regression model 4

Table 9.I Agreement with statements concerning women's roles in the public sphere (in \%)

Table 9.2 Actual division of household tasks in two types of households (in \%) 
Table 9.3 Attitudes towards the division of household tasks in imaginary families with children, support of the traditional division of tasks (in \%)

Table 9.4 Summary of GLM results on two attitude scales, F-value and significance

Table 9.5 Determinants of attitudes towards gender roles in the public and private sphere by ethnicity, F-values and significance

Table i2.I Description of sample

\section{Figures}

Figure 2.I Map of Estonia $\quad 27$

Figure 2.2 Share of Estonians in population, I January $2008 \quad 30$

$\begin{array}{lll}\text { Figure 2.3 Map of Tallinn } & 32\end{array}$

Figure 2.4 Map of Ida-Virumaa $\quad 32$

Figure 2.5 Age distribution of the TIES project respondants 36

Figure 3.I The Estonian model of multiculturalism 52

Figure 4.I The Estonian educational system 62

Figure 4.2 The changing share of students studying in a language other than Estonian in basic and general secondary schools (only daytime studies) (in \%)

Figure 4.3a Gross and net ethnic educational disadvantage: Odds of transition to general secondary school (versus other type of secondary education)

Figure $4.3 \mathrm{~b}$ Gross and net ethnic educational disadvantage: Odds of transition to, and completion of, higher education (versus not continuing studies in higher education after attainment of secondary education or not finishing these studies)

Figure 4.4 Probabilities of transition to general secondary school by ethnicity and social origin

Figure 4.5 Probabilities of transition to and completion of higher education by ethnicity and social origin

Figure 5.I Estonians and Russians employed in the primary, secondary and tertiary sectors in I989, I994 and 2008 (in \%)

Figure 5.2 The occupational status of Estonians and secondgeneration Russians in Tallinn and Kohtla-Järve (in \%) 
Figure 5.3 Predicted probabilities for Russians and Estonians with different educational levels to attain a managerial, professional or specialist position (other independent variables are set to mean)

Figure 6.I Employment and unemployment rates of Estonians and non-Estonians, I997-2008 (in \%)

Figure 6.2 Population according to employment status, by gender and age group, 2006 (in \%)

Figure 6.3 Gross and unexplained wage differential in favour of ethnic Russians compared with Estonians (in \%)

Figure 6.4 Distribution of Estonian and non-Estonian population by income quintiles, 2006 (in \%)

Figure 6.5 Current employment status by ethnicity and age (in \%)

Figure 6.6 Structure of income sources of respondents' own household by ethnicity (in \%)

\section{Chapter appendices}

Appendix 4.I Stepwise logistic regressions: Model fit

Appendix 5.I Access to managerial, professional and specialist positions, separate logistic regression models for Estonians and Russians

Appendix IO.I Sense of belonging to Estonia strongly or very strongly, odd ratios (Exp (bi)), logistic regression models 


\title{
1 Introduction
}

\author{
Raivo Vetik and Jelena Helemäe
}

\subsection{The integration issue in Estonia}

Interethnic relations in Estonia present a puzzle for studies of immigrant integration. One trend in the literature argues that the historical need to define the position of the Estonian nation vis-à-vis the position of the new Russian minority in the country has accelerated the transformation of Estonia from an ethnic nation to a modern civic nation (Lauristin \& Heidmets 2002). The other much more critical trend in the literature maintains that the influence of the legal-restorationist concept, adopted by ethnic Estonian elites at the beginning of the I990s, continuously reinforces interethnic alienation in Estonia (Brosig 2008). This trend is bolstered by regular integration monitoring carried out in Estonia since the year 2000, as well as a number of political events in the last few years. Of particular note is the Bronze Soldier crisis in April 2007 , which led to the arrest of more than a thousand young Russians who protested against the removal of the Soviet era war memorial from downtown Tallinn (Ehala 2009).

The recent increase in tensions related to second-generation immigrants is not a unique phenomenon in a broader European context. However, the reasons behind this development are very specific in Estonia. These tensions have been shaped by social and political processes from both the Soviet period (since 1945) and the post-independence period (since I99I). The first major peculiarity of the Estonian integration issue, as compared to most other European countries facing the challenge of integrating the second generation, is that as many as one third of the current Estonian population is of immigrant origin. Ethnic Russians form the biggest minority group, comprising about 26 per cent of the total population, and altogether there are representatives of more than a hundred different ethnic groups. According to the census of 1934, before the Soviet occupation of 1940 Estonians comprised 88 per cent, Russians 8 per cent and other nationalities 4 per cent of the population of Estonia. Russians in Estonia lived mainly in the border regions of Narva, Peipsi and Petseri. In I945, the Soviet authorities redrew the border between Estonia and the Russian Federation and, as a result, Estonia lost the border regions inhabited by native Russians. 
This left Estonia as a very homogeneous country where ethnic Estonians formed 97.3 per cent of the population.

However, in the period I945-1989, the percentage of Russian speakers in Estonia grew from 26,000 to 602,000 (Vetik 1993). Such a dramatic demographic shift is the result of the policies of the Soviet Union after World War II, which aimed to reconstruct Estonia - both economically and socially - as an integral part of the Soviet Union (Mettam \& Williams 200I). Soviet policies should be seen in a broader historical context as well; Estonia was part of the Russian Empire from I72I until I9I8. In February I9I8, local Estonian elites took advantage of the military weakness of both Germany and Russia and declared Estonia's independence. The Tartu Peace Treaty, in which Russia renounced future claims on Estonian territory, was signed between Estonia and Soviet Russia in February 1920. During subsequent decades, Estonia engaged in a full-scale nation-building project, achieving remarkable success both in the economic and cultural realms and developing into a modern nation state. However, in September 1939, under threat of military intervention, the Estonian government accepted a pact of defence and mutual assistance with the USSR. This led to the establishment of a puppet government, backed by Moscow, in Tallinn in June I940. During World War II, after the German occupation of I94I-I944, the Soviet regime was re-established in Estonia and endured for the next half a century.

Thus, parents of second-generation Russians arrived in Estonia as citizens of the Soviet Union. The relationship between Estonia and Russia during the Soviet period can be conceptualised in terms of colonialism (Kuzio 2002), which means that the current integration context has certain features of the post-colonial condition. While the post-colonial condition is not unique in the European context, a major difference between the cases of Estonia and a number of other Western European countries with imperial legacies is that in the latter cases immigrants have arrived in the imperial centre from ex-colonies. In Estonia, the direction of movement has been reversed and included a remarkably high proportion of well-educated migrants. The specificity of the current integration issue in Estonia is shaped by the fact that during the Soviet period the official policies and institutions strongly supported the structural integration of Russian immigrants in Estonia. For example, a number of economic spheres and political institutions operated only in Russian and the migrants working mostly in all-Union enterprises had privileges in getting housing, and benefited from the establishment of a separate Russian language education system. Such policies, coupled with the territorial concentration of Russians in the north-east of Estonia and Tallinn (see Sokolova in this volume), the socio-economic segregation of the Estonian housing sector (see Ojamäe \& Paadam in 
this volume) and the comparatively smooth structural integration of Russians into Estonia in the Soviet period, were accompanied by high ethnic segmentation within Estonian society as a whole. This must also be seen in the context of bureaucratic divisions between all-Union enterprises - which mainly employed Russians - and local enterprises where the workforce was mainly Estonian (see Lindemann in this volume), as well as parallel educational systems, which divided the population on the basis of the language of instruction (see Saar \& Lindemann in this volume).

In addition, Russian language migrants remained culturally divorced from Estonian society, representing a category of so-called 'Soviet people' with no urgent need to learn the Estonian language or engage with local people (Raun I99I). The response of ethnic Estonians to these policies of Russification and the social changes that occurred during the Soviet period manifested itself in various individual-level cultural resistance movements. For example, in comparison to other national republics of the Soviet Union, knowledge of the Russian language by ethnic Estonians was particularly low (Hogan-Brun, Ozolins \& Ramoniene 2007). This can be regarded as a conscious attempt to reproduce the parallel existence of the two communities and, in this way, to resist Soviet rule.

The main features of the Soviet heritage, to be taken into account in analysing the current integration issue in Estonia, are the existence of two parallel societies with minimal interaction both in the structural and cultural domains, as well as the agencies of the 'threatened majority' and the formerly 'privileged minority'. However, the integration issue in Estonia must also be viewed in the context of the fundamental social and political changes that resulted from the country regaining independence in I99I. These changes are related to the establishment of a number of new institutions aiming to continue the nation-building processes along the lines of pre-Soviet time. For example, in I992, the Estonia Parliament adopted the citizenship law, which establishes legal continuity with the Estonian Republic of I918-1940. The law is exclusive in the sense that citizenship is granted only to those residents and their descendants who were citizens of Estonia before Soviet occupation. The law requires two years' residency before a person is entitled to apply for citizenship, and a further one-year waiting period before the applicant can be naturalised. The law also includes a loyalty oath and restricts certain categories of people from gaining citizenship (Soviet military officers, foreign intelligence, etc.). In addition, the law requires knowledge of the Estonian language, which has effectively resulted in the majority of Russians currently living in Estonia becoming stateless (Vetik \& Kionka I996). 
The issue of parallel societies deriving from the Soviet period, then, has also expanded into the legal domain. From a legal standpoint, the Russian language population - already culturally separated from ethnic Estonians - became immigrants. In structural terms, the two communities have been deeply segregated. The I992 citizenship law, as well as other similar measures undertaken by the Estonian political elite at that time, should be seen in the context of high levels of threat perceptions and distrust between the Estonian majority and Russian minority at the beginning of the I990s. This is illustrated by the I99I referendum, in which only 25 per cent of the Russian population voted in favour of Estonian independence, compared to the majority of ethnic Estonians who were pro-independence (Vetik I993). Thus, only six months prior to the regaining of independence, Estonian society was fundamentally polarised by one of the most existential political issues, inevitably evoking strong mutual fears regarding the future. In addition, the impact of regular interstate tensions between Estonia and Russia has been strengthening threat perceptions among Estonians, becoming one of the most important features of the current integration issue in Estonia (Vetik 2009). This leads us to another major difference between Estonia and most West European societies facing the integration challenge - Estonia's majority native group is much more consolidated compared to the country's migrant minorities, which have remained remarkably fragmented, both socially and politically, throughout the postindependence period.

Following the introduction of market reforms at the beginning of the I990s, economic well-being became highly problematic for most people in Estonia, irrespective of their ethnic background or citizenship status. A particularly deep recession hit certain branches of the country's economy, including the oil shale industry in north-east Estonia, which has traditionally had strong links to the Soviet economy and whose workforce is generally Russian-speaking. In fact, the structural logic of market reforms has tended to move the minority group into inferior positions in several segments of the Estonian labour market. Unemployment has also tended to be higher among Russian speakers, compared to Estonians, during the last two decades. This overrepresentation of minorities among the ranks of the unemployed can be seen especially among people with advanced levels of education (Helemäe 2008). Previous research indicates that the emergence of ethnic inequality in the labour market is a consequence of several factors, including the lack of Estonian citizenship and insufficient proficiency in Estonian language among Russians (ibid.).

In this context, however, it is important to note that a number of policies have been adopted by the Estonian government that aim to integrate the Russian population into Estonian society. First, equal social 
protection is granted to all legal residents regardless of their citizenship status. Second, residents with undetermined citizenship have been given the right to vote in local elections, offering them an important channel to influence the political system in Estonia. Furthermore, a number of measures to improve the position of the Russian language youth have been launched in the field of education recently. Since the start of the 2007 academic year, for example, all Russian language secondary schools are undergoing a transition to make Estonian one of the languages of instruction. The idea behind this reform is that after a transition period of five years, 60 per cent of all instruction in these schools will be carried out in Estonian, helping the young Russian second generation to achieve parity with their Estonian counterparts as they enter the labour market. However, as the results of this volume indicate, many members of the Russian minority perceive this policy as an attempt at 'assimilation'.

\subsection{Conceptual background}

The following chapters discuss the results of a research project in two Estonian cities - Tallinn and Kohtla-Järve - which forms part of a larger comparative project 'The Integration of the European Second Generation' (TIES). Conceptually, the TIES project is based on the central importance of the integration context for outcomes of integration processes, something that has been rather marginal in previous research. Most previous studies on the integration of the second generation have been limited to one country and the local and national integration contexts have been taken for granted, which presumes that the focus of the analyses has been on the migrant groups themselves. In contrast, the TIES project focuses on the importance of the local and national contexts by comparing the same ethnic groups, with the same starting position, across different cities and countries.

The TIES project understands integration as the process of inclusion of immigrants in the core institutions, relations and statuses of the receiving society. Four dimensions of integration can be differentiated for analytical purposes: structural, cultural, social and identification integration (Bosswick \& Heckmann 2006: Io). Structural integration has to do with equal access to education, the labour market and other institutions by all groups in the society, regardless of their ethnic background. Cultural integration amounts to immigrants developing competence in the language and culture of the receiving society. Social integration is related to the issues of ethnic segmentation and intermixing between a receiving society and immigrant groups. Identificational integration 
includes feelings of belonging to, and identification with, groups on ethnic, national and other levels (Schulze 2006).

However, the TIES project also problematises the concept of integration. In the public debate in Europe, the term integration is often used as a synonym for classical linear assimilation - full integration of immigrant minorities in all domains, defined normatively from the position of 'core values' of the majority group. Such an approach, however, fails to tackle the questions related to contextual factors, such as: integration into what? The TIES project posits that the second generation has not arrived in a society new to them, rather, it makes much more sense to look at their integration into specific integration domains, such as school, work or the neighbourhood. In this way, the presumption that national integration models have an overall positive or negative effect on all domains of integration is not taken for granted. Such an approach presumes that all groups in a society need to be integrated, not only minorities.

The TIES sub-project in Estonia is based, largely, on these general theoretical presumptions. In particular, the concept of integration is understood in this volume as a process during which distinctions along ethnic, cultural and social lines are becoming less relevant in public and social settings (Thomson \& Crul 2007). Thus, integration is not defined in the project along the linear model, which would presume the existence of the 'Estonian core', into which the minorities need to be immersed in order to become fully integrated. Instead, integration is understood as the 'decline of an ethnic distinction and its corollary cultural and social differences' (Alba \& Nee 2003) along the conceptual model of boundary construction and in the sense of a process of the 'blurring' of boundaries that used to be 'bright' (Alba 2005). Thus, integration within this conceptual model is understood as a two-way process, which can never be 'fully finished', in the same way that boundary construction in intergroup relations is, by definition, a process combining the elements of both social inclusion and social closure (Weber I968). The process of integration is considered to be shaped both by the agency of immigrants (and their communities) and natives, as well as by the integration context, including major social institutions, public policy and community responses to immigration, which form the opportunity structure for migrant integration.

Within the conceptual model described above, the opportunity structure for integration in Estonia can be characterised by the existence of two very specific agents operating in a very specific integration context, as compared to other integration countries in Europe. On the one hand, second-generation Russians represent an atypical category of 'semi-immigrants', who can be regarded as immigrants in Estonia in some respects, but non-immigrants in others. They have acquired this in- 
between status involuntarily as a result of the drawing of new state boundaries between Estonia and Russia when Estonia regained independence in I99I, and by the nationalising policies redrawing previous social and political boundaries within Estonia since then. Both the nationalising policies and new boundaries tend to construct Russians as 'immigrants' in Estonia, and the majority of Russians perceive both as discriminatory (Kruusvall 2000). On the other hand, due to the described Soviet policies, ethnic Estonians represent an atypical category of a 'threatened majority'. Threat perceptions regarding immigrants are found in other European countries as well, but the Estonian case is specific due to the fact that post-communist Russia is still trying to maintain control over the so-called 'near abroad' (Trenin 2005). Estonia is responding by drawing particularly strong boundaries between the two countries, along the lines of the ideology of 'clashing civilisations' (Saar I998). The perception of a particularly strong mutual threat by both the minority and the majority group is one of the most important elements in the integration issue in Estonia, forming a fertile ground for reactive processes and potential conflict along ethnic lines (Vetik 2007).

Within the described conceptual framework, a number of research questions have been formulated and discussed in this volume. Our general research question can be formulated as: what is the impact of the described opportunity structure on the integration processes of secondgeneration Russians both in terms of the parity of the ethnic groups as well as the social cohesion of Estonian society as a whole? Within this general framework, we are interested in, among other things, the changing ethnic inequalities in terms of both educational attainment and the labour market situation: how great are the ethnic disparities between the Russian second generation and their Estonian counterparts compared to their parents' generation during the Soviet period? We have also asked about the reaction of the Russian second generation to the policies they perceive as discriminating and how this reaction impacts the relationship between instrumental and emotional aspects of their integration processes. Finally, we are also interested in the conflict potential of the current integration issue in Estonia, particularly in the context of diverse collective memories and different identities stemming both from the Soviet era and from the current nationalising state. In this context, we pose the question, what is the potential for the ethnic mobilisation of young Russians in Estonia?

Most of the empirical data presented in the current volume is based on the TIES survey in Estonia. However, other research data has been utilised in the following chapters in order to give a fuller account of the integration issue in Estonia. The main source of this additional information is the Statistics Estonia database. The Estonian project has followed both the conceptual framework and research methodology of the 
general TIES questionnaire as closely as possible, while a number of new elements were added to the instrument in order to take into account specific features of the Estonian case.

In line with the general TIES project, which is based on an international standardised survey of second-generation immigrants and a comparison group of 'natives' between the age of I8-35 years, second-generation Russians and a comparison group of Estonians, within the abovementioned age range, were surveyed in the period from January 2007 to March 2008. The second-generation Russians were defined as those who a) consider themselves to be Russians (when asked the question 'What is your ethnicity?' they responded, 'Russian'); b) were born in Estonia; and c) had at least one parent who was born in Russia or another former Soviet Republic (but not in Estonia). In line with the general TIES project, I,000 face-to-face interviews (488 with Estonian youth and 5 I2 with Russian youth) were conducted in Tallinn and in two locations in Ida-Virumaa: Kohtla-Järve and Jõhvi. These two cities were chosen in order to contrast two different local contexts of integration in Estonia. Tallinn is the capital city and the ethnic composition of Estonians and non-Estonians (the majority of whom are Russian) is almost fifty-fifty (see Sokolova in this volume). Tallinn has the highest concentration of resources and opportunities for getting ahead, but the highest levels of competition too. Kohtla-Järve and Jõhvi (which was part of Kohtla-Järve during Soviet times) are cities in Ida-Virumaa where, by the end of the Soviet period, Russians had become a majority and their concentration even increased following the restoration of independence (Sokolova in this volume). Compared to the capital city, the opportunities for the residents of these two Ida-Virumaa cities to get ahead are rather scarce and the risk of unemployment is one of the highest in Estonia.

\subsection{Chapter contents}

The present volume will study simultaneous processes of overcoming the barriers to the integration of second-generation Russians in different dimensions of social life in Estonia, as well as the continuous reproduction of ethnic segmentation and disparity between natives and immigrants. We will analyse these phenomena within a framework of both the agencies and context of integration. We seek to understand the impact of specific factors on integration outcomes, as well as the socio-cultural resources of adaptation used by the Russian second generation across different dimensions of integration.

In the chapter Migration patterns, Nastja Sokolova provides the reader with an understanding of why immigration and integration issues are 
of such high importance for Estonia. An historical overview of immigration describes the general demographic situation in Estonia, explains the centrality of the demographic issue in the post-Soviet nation-building process and reveals the sources and peculiarities of migration flows to Estonia. A description of the demographic situation in the surveyed cities is also offered. The second section of the chapter is based on data from the TIES project and focuses on the general statistics of the respondents (age, gender, citizenship) and the background of their parents.

Raivo Vetik's chapter, Integration policies, is divided into four sections. The introductory section sketches the main lines of debates on Estonian integration policies in the literature available. The second section specifies the main challenges of the generic integration policy in Estonia, as compared to other integration countries in Europe. The third section is devoted to conceptualising the Estonian integration model. It locates it within the context of debates relating to the relationship between individual and group rights in liberal social theory. The fourth section takes the theoretical perspective of the previous sections and analyses the primary documents of the integration strategy adopted by the Estonian government in the period I998-2008. The aim of this chapter is not to provide a detailed description of the concrete integration measures implemented by the government agencies, but rather to conceptualise these measures within broader historical and theoretical contexts. This approach connects this chapter to others in the volume in order to elucidate the social processes scrutinised within them.

Subsequent chapters are devoted to the analysis of the position of the Russian second generation in Estonia. Like the general TIES survey, the current study explores both structural and cultural integration, but gives a special focus to structural integration and in particular the educational system and the labour market. The chapters in this section address structural integration in terms of educational careers; the position of, and income returns from, human capital in the Estonian labour market and housing conditions.

In the chapter Ethnic inequalities in education, Ellu Saar and Kristina Lindemann examine ethnic stratification in the Estonian school system, focusing on the different tracks chosen in secondary education and on the transition to higher education. They investigate whether differences in parents' class and educational experience have any bearing on the educational transitions of the second generation. They specifically look for answers to these questions: I) Does the effect of social background vary between second-generation Russians and Estonians? 2) To what extent does the country-specific capital of the parental generation influence the educational transitions of second-generation Russians? In order to give an overview of the changes over immigrant generations, they 
compare the educational attainment of Estonians and Russians with that of their parents.

In the chapter Explaining different returns from human capital in the labour market, Kristina Lindemann returns to research second-generation Russians' access to higher occupational positions in the Estonian labour market. Her study examines to what extent differences between natives and the second generation in terms of access to higher positions are explained by human capital. The central question is whether, and why, labour market returns from education differ for second-generation Russians and young Estonians? The chapter attempts to explain how second-generation labour market disadvantage is related to countryspecific human capital, parental resources and social networks. The impact of structural conditions and labour market segmentation is also addressed.

Rein Vöörmann and Jelena Helemäe's chapter, Income inequality, is focused on the outcomes of the labour market integration of secondgeneration Russians compared to their Estonian counterparts. The problems Russians experience integrating into the labour market raises the question of the relative importance of income from employment compared to state and parental support. As in the preceding chapter, the relative probability of Russians attaining a high labour market position (this time in terms of income) compared with Estonians is addressed, and the importance of both general and country-specific capital is highlighted.

Housing conditions and neighbourhood satisfaction are addressed in Liis Ojamäe and Katrin Paadam's same-named chapter. The authors focus on the specific context for the formation of modern ethnic distinctions in the Estonian housing field. This is done with reference to two deeply interrelated historical transformations that have profoundly changed the relations in the field and in Estonian society at large. The article explores linkages between the socio-structural context characteristic of the previous Soviet socialist system, which irreversibly affected the housing structures and contemporary differences in the housing behaviour patterns of Estonians and Russians, as well as their urban residential and regional segregation. It is argued that, in view of future residential prospects, it is viable to enquire whether ethnic distinctions in residential behaviour persist, as well as whether they continue to influence ethnic segregation and neighbourhood satisfaction.

Subsequent chapters are devoted to different aspects of social, cultural and identificational integration. Jennie Schulze's chapter, Contact and crisis in interethnic relations, sheds light on attitudes towards interethnic relations among second-generation Russians and young Estonians by drawing on classic studies of interethnic relations. Following independence, relations between ethnic Estonians and ethnic Russians were 
remarkably peaceful. The Bronze Soldier crisis of April 2007, however, created a new situation. Surveys conducted after the spring of 2007 have shown that the April crisis had a greater impact on the attitudes of the youngest generation from both ethnic groups. Through an analysis of the TIES survey data, this chapter contributes to micro-level theories of interethnic relations by evaluating the comparative impact of the Bronze Soldier crisis, interethnic contact and experiences of discrimination on four different measures of interethnic relations in Estonia. Rather than building a general model to explain interethnic attitudes among respondents, this chapter examines whether these variables matter at all for interethnic relations among Russian and Estonian youth.

The chapter Gender role attitudes, contributed by Leeni Hansson, provides an overview of the attitudes of second-generation Russians and young Estonians towards gender roles in the public and private spheres. The study reveals that although we can speak of a certain equalisation of attitudes among young people with different ethnic backgrounds in the public sphere, there are noticeable differences in attitudes concerning gender roles in the domestic sphere. Young Russians, and young Russian men particularly, support a more traditional division of tasks and responsibilities in the family than young Estonians. The author finds some similarities in the familial attitudes of young Russians and in the attitudes of native Estonians in the early I990s. Whereas in the I990 the signs of re-traditionalisation were explained as a reaction to the former Soviet gender contract, today the support of traditional family values and family roles characteristic of second-generation Russians could be related to their relatively more disadvantaged position in the labour market.

In the chapter Sense of belonging to Estonia, Gerli Nimmerfeldt examines the integration processes of second-generation Russians at the identity level - often referred to as identificational integration. The chapter is based on the assumption that identification with one's ethnic group and identification with the host society and country complement each other. It endorses the observation that identificational integration therefore involves not only the decline or retention of ethnic identity and identification with the majority group, but also the formation of a sense of belonging to the country and society where second-generation Russians are born and grow up. In order to explore the sense of belonging to the host society and country, a novel operationalisation is proposed. It is based on the expression of feelings of being at home in the country of residency and feelings of being accepted by, and being a part of, that society. The analysis explores the formation of such a sense of belonging based on the connection and emotional attachment to the country and feeling of being part of the society. The impact of several objective and subjective level factors on the sense of belonging to 
Estonia are analysed, including formal and legal membership through citizenship, experienced and perceived discrimination, close relations with Estonians, transnational ties and activities and perceived threat to cultural identity. Furthermore, the impact of parental background and country-specific human capital, as well as personal socio-demographical characteristics and indicators of the level of structural integration and acculturation on the sense of belonging, are controlled.

\section{References}

Alba, R. (2005), 'Bright vs. blurred boundaries: Second-generation assimilation and exclusion in France, Germany and the United States', Ethnic and Racial Studies 28 (I): 2049.

Alba, R. \& V. Nee (2003), Remaking the American mainstream: Assimilation and contemporary immigration. Cambridge: Harvard University Press.

Bosswick, W. \& F. Heckmann (2006), Integration of migrants: Contribution on local and regional authorities. Dublin: European Foundation for the Improvement of Living and Working Conditions.

Brosig, M. (2008), 'A plan for the future? The Estonian state integration programme on national minorities 2000-2007', Journal on Ethnopolitics and Migration Issues in Europe 7 (2): I-I9.

Ehala, M. (2009), 'The Bronze Soldier: Identity threat and maintenance in Estonia', Journal of Baltic Studies 40 (I): I39-I58.

Helemäe, J. (2008), 'Tööalane eneseteostus ja selle võimaluste tajumine (Self-realisation at work and perceived opportunities for it)', Aruanne (Integration of Estonian Society, Monitoring 2008. Report). Tallinn. www.rahvastikuminister.ee/?id=I205I. Accessed I5 January 2009.

Hogan-Brun, G., U. Ozolins \& M. Ramoniene (2007), 'Language politics and practices in the Baltic states', Current Issues in Language Planning 8 (4): 469-63I.

Kruusvall, J. (2000), 'Understanding integration in Estonian society', in M. Lauristin \& R. Vetik (eds.), Integration in Estonian Society: Montoring 2000, I4-22.Tallinn: MEIS.

Kuzio, T. (2002), 'History, memory and nation building in the post-Soviet colonial space', Nationalities Papers 30 (2): 24I-264.

Lauristin, M. \& M. Heidmets (eds.) (2002), 'Introduction: The Russian minority in Estonia as a theoretical and political issue', in M. Lauristin \& M. Heidmets (eds.) The challenge of the Russian minority, I9-30. Tartu: Tartu University Press.

Mettam, C.W. \& S.W. Williams (200I), 'A colonial perspective on population migration in Soviet Estonia', Journal of Ethnic and Migration Studies 27 (I): 133-I50.

Saar, J. (I998), 'Tsivilisatsioonide kokkupõrke teooria retseptsioonist Eestis (About the reception of the clash of the civilizations theory in Estonia)', Akadeemia 7: I5I2-I5I9.

Schulze, J. (2006) 'After conditionality. minority integration in Estonia, Latvia, and Slovakia', PhD proposal at GWU.

Thomson, M. \& M. Crul (2007), 'The second generation in Europe and the United States: How is the transatlantic debate relevant for further research on the European second generation?', Journal of Ethnic and Migration Studies 33 (7): IO25-I04I.

Trenin, D. (2005). Russia, the EU and the common neighbourhood. Moscow: Carnegie Moscow Centre. www.carnegie.ru/en/pubs/media/732I2.htm. Accessed I5 January 2009 . 
Vetik, R. (1993), 'Ethnic conflict and accommodation in post-communist Estonia', Journal of Peace Research 30 (3): 27I-280.

Vetik, R. (2007), 'Suur ühiskond (Great society)', in R. Vetik (ed.), Kahe vabaduse piiril (On the border of two freedoms), 73-90. Tallinn: K Print.

Vetik, R. (2009), 'The cognitive mechanisms of reproducing confrontation in EstoniaRussia relationship'. Manuscript submitted for publication.

Vetik R. \& R. Kionka (1996), 'Estonia and Estonians', in G. Smith (ed.), The nationalities question in the post-Soviet states, I29-I46. London: Longman.

Weber, M. (1963), The sociology of religion. Boston: Beacon Press. 



\title{
2 Migration patterns
}

\author{
Nastja Sokolova
}

\subsection{Introduction}

Russians form the largest minority group in Estonia, constituting 26 per cent of the total population. Although some Russians have lived in the territory for centuries, the majority of today's Russian population came to Estonia during the last 60 years. The current chapter seeks to describe Russian migration patterns to and within Estonia during this period. It also summarises the 2000 population census statistics with regard to several key measures relevant in the context of this volume, as well as offering an overview of the TIES project data basic descriptive statistics.

Figure 2.1 Map of Estonia

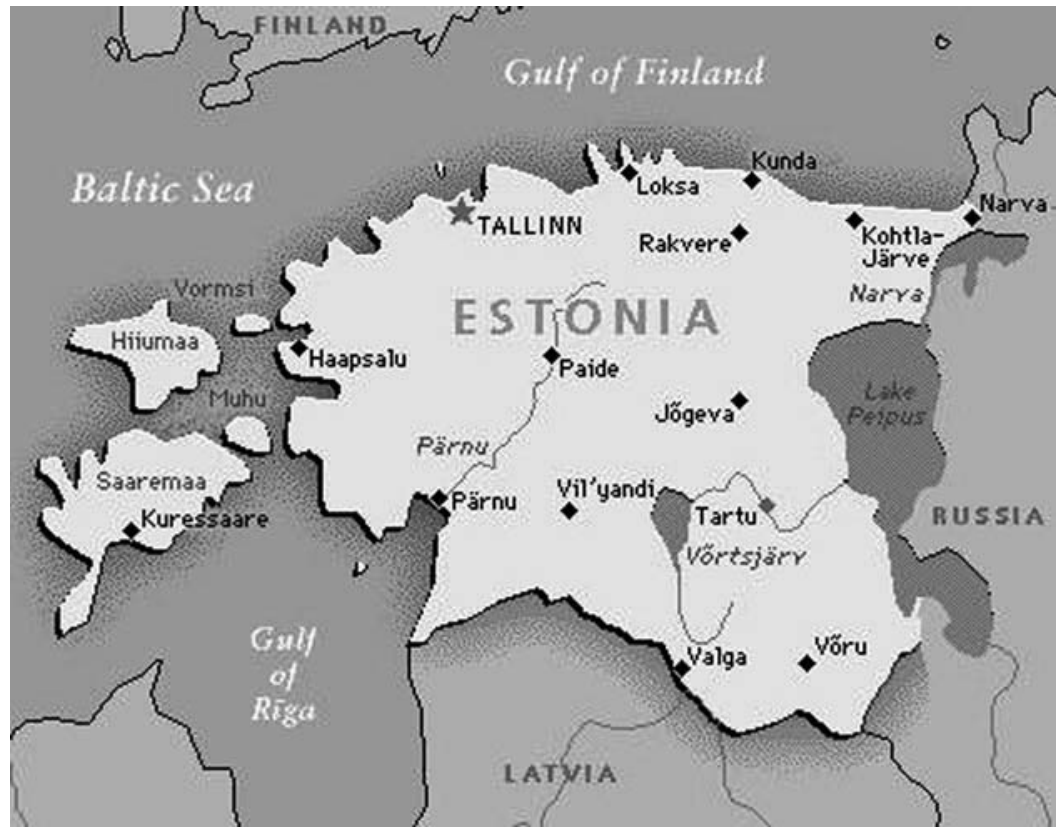

Source: wwp.greenwichmeantime.com/images/europe/estonia.jpg 


\subsection{Migration patterns}

During the first independence period (I9I8-I940), Estonia was a rather ethnically homogeneous country. Estonians constituted about 90 per cent of the population. Among other ethnic groups, the country was home to Russians, Baltic Germans and Swedes. Just before the end of World War II, there was a short period where the proportion of Estonians reached 97 per cent (with other minorities constituting around 3 per cent) (Kulu I998: 2). Soviet repression, war losses and emigration reduced the Estonian population by a fifth in the I940s (Hallik I998: I4). Almost immediately after the occupation of Estonia by Soviet forces in I944, people of other ethnicities started arriving in the country in large numbers. Immigration was one of the main factors for a growth in the population from 854,000 in 1945 to almost twice that number $(1,565,662)$ in I989 (Kulu 2001: 2388).

The first years after the end of World War II saw the biggest inflows of immigrants to Estonia - up to 45,000 people a year (ibid.). In the I950s, the numbers dropped to 35,000-40,000 people a year. By the I980s, this had diminished by half. Out of the little over one million people who arrived in Estonia between I946 and I991, about one third (around 350,000 people) decided to stay (Sakkeus I99I). Russians were the largest ethnic group among immigrants and they still form a substantial minority. In I959, they already constituted 20.I per cent of the population, a sharp increase from their share in I945. By I989, the percentage grew even further to the point that almost a third of the Estonian population were Russians (SOE I995). Other noteworthy ethnic groups that became a fixture in the country's population during the same period are Ukrainians (3.I per cent) and Byelorussians (I.8 per cent). Despite different ethnic backgrounds, more than half of the nonRussian immigrants arriving in Estonia spoke Russian as their mother tongue (Katus, Puur \& Põldma 2005: L).

One of the reasons behind the initial waves of immigration to Estonia immediately after the end of World War II was the reconstruction that followed the destruction of the war. The majority of newcomers had

Table 2.1 Change in population in Estonia during the Soviet period by ethnic group

\begin{tabular}{lccccc}
\hline Census years & Estonians & Russians & Ukrainians & Byelorussians & Population in total \\
\hline 1959 & 892,653 & 240,227 & 15,769 & 10,930 & $1,196,791$ \\
1970 & 925,157 & 334,620 & 28,086 & 18,732 & $1,356,079$ \\
1979 & 947,812 & 408,778 & 36,044 & 23,461 & $1,464,476$ \\
1989 & 963,281 & 474,836 & 48,271 & 27,711 & $1,565,662$ \\
\hline
\end{tabular}

Source: Population of Estonia by population census, Statistical Office of Estonia 1995 
only elementary or basic education (Kulu 200I), although a substantial number of newly arrived had high levels of education and qualifications enabling them to fill administrative positions in the local Communist party hierarchy and strategically important enterprises (Sakkeus I999). As the general level of education improved, and as the need for unskilled labour diminished, the educational background of immigrants changed. Among the immigrants who came to Estonia in the I96os, those who had completed high school education prevailed; and starting from the I970s, the share of newcomers with a university diploma or its equivalent eventually exceeded the 20 per cent mark (Kulu 200I: 2385). It is worth noting that in the period 1959-1989 the share of Estonians and minorities with university and high school level education increased substantially, while the share of those with only elementary level education decreased almost by half (ESO I995).

During the Soviet period, Estonia experienced rapid urbanisation. As a result, the 1989 census revealed that more than 90 per cent of those who arrived in the republic after World War II, and their children, lived in urban areas (Katus \& Sakkeus I993). A number of Russians who originally came to work in Ida-Virumaa later moved to Tallinn due to the increased opportunities - job and otherwise - that the capital city offered (Marksoo 2005).

During the first decades after the end of World War II, immigration resulted in the patterns of distribution of Russian inhabitants (as well as representatives of other ethnicities) that are very much visible today. The vast majority of newcomers settled in Tallinn, the capital of Estonia and in the north-east of the country, mostly in Ida-Virumaa County (see Figure 2.2). This was due to the rapid industrialisation of the capital and Ida-Virumaa, and the strategy of establishing a firmer hold on the territory by having more non-local specialists in the administrative and high-level positions in strategically important industries, such as the mining and energy sectors (Kulu I998; Sakkeus 1999). Starting from I96os, immigration became less centralised and was organised mostly via local enterprises and personal ties, which resulted in an even higher concentration of immigrants in the same regions. Towards the end of the Soviet period, Russians became a majority in many Ida-Virumaa cities (Narva, Kohtla-Järve, Sillamäe and Jõhvi) and almost tipped the balance in Tallinn (Sokolova 2008). In I989, Estonians constituted a mere 47.4 per cent of the capital's population.

After I99I, Tallinn and urban Ida-Virumaa witnessed positive net migration (Sjöberg \& Tammaru I999). However, while people arrived in Tallinn from other parts of Estonia, Ida-Virumaa witnessed mostly local migration. Furthermore, while Russian inhabitants preferred to stay in the north-east, Estonians were more likely to move from there to other regions. Thus, the immigration patterns that occurred in the I990s 
Figure 2.2 Share of Estonians in population, 1 January 2008

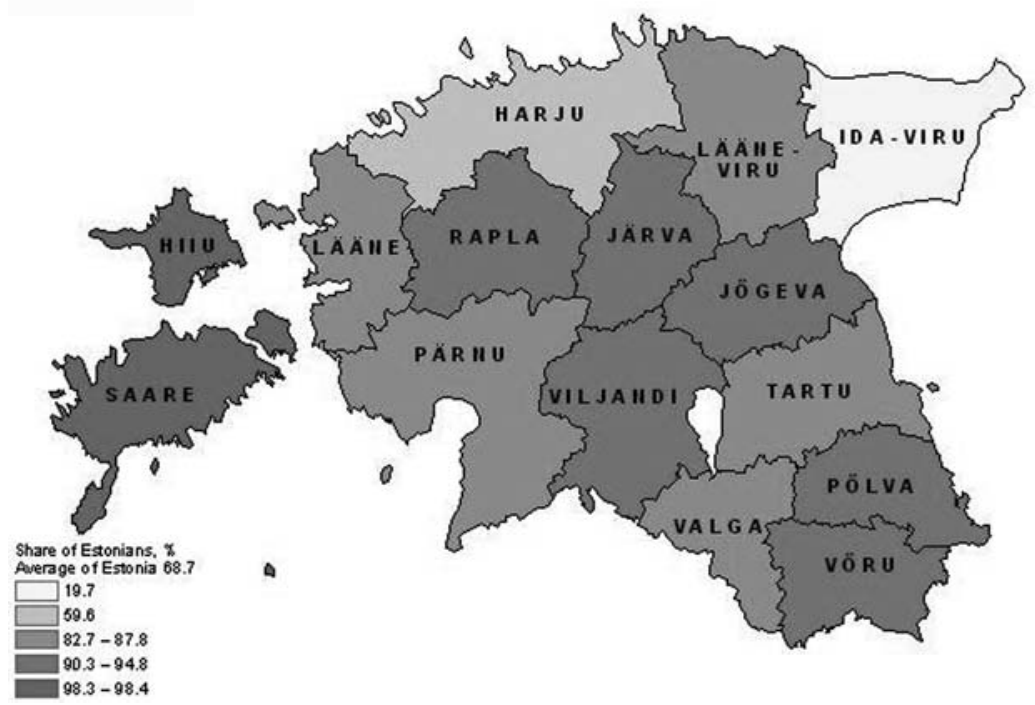

Source: Statistical Office of Estonia

produced mixed results. On the one hand, Tallinn remained an attractive destination for both Estonians and Russians, becoming a place where representatives of different ethnic groups had a better opportunity to interact. On the other hand, ethnic segmentation in Ida-Virumaa increased further after the restoration of independence (ibid.; Kulu \& Billari 2004).

With internal migration becoming easier, external immigration was curbed drastically. Currently, Estonian migration policy is rather restrictive, evolving in the direction of 'selective limitation of immigration' (OMPEA 2009). Although there are no limits set for European Union citizens, the annual quota for immigrants from third countries, excluding the United States and Japan, is set at 0. or per cent of the population (around I,340 people). The policy clearly states a preference for the return of people of Estonian origin and highly skilled professionals. As of the beginning of 2009 , there were less than $\mathrm{I}, 000$ residents holding the permanent and temporary residence permits granted to people from third countries (excluding former Soviet republics, Japan and the US) and only 23 people received asylum and other protection (CMB 2009). 
Tallinn is the capital of Estonia and the administrative centre of Harju County, which is in the north-west of the country. During the Soviet occupation, Tallinn played a very important role due in part to Moscow's central policy of developing local capitals, and in part because it is an industrial town with a good geographical position (Marksoo 2005).

During much of the Soviet period, the city remained an attractive destination both for internal and external migration flows. Sometimes, a shortage of accommodation meant that the flow of migrants had to be curbed. However, despite the limitations on arriving workers that were put into place by the city administration in the middle of I950s, the population continued to increase. In fact, the restrictions were abolished rather quickly thanks to the construction of new apartment blocks. From the Ig6os, Tallinn was attracting more migrants (mostly Russians) than any other region or town in Estonia. Between I965 and I974, the city's population grew by 39 per cent and in the subsequent decade this percentage rose to 53 (Marksoo 2005: 67). The changes that followed independence in I99I (i.e. the emigration of many ethnic minority representatives to Russia and other former Soviet republics) reversed this trend. In 2008, Tallinn had 40I,372 inhabitants, 52.3 per cent of whom were Estonians (TCG 2008). The city is home to 42.I per cent of all Russians living in the country (SOE 2009).

Tallinn is divided into eight districts (see Figure 2.3) and the percentages of Estonians and Russians in those districts differ. Lasnamäe, the most populated district (where a quarter of Tallinn residents live) has only 28.6 per cent of Estonians. The other district where Estonians constitute a minority is Põhja-Tallinn (4I.9 per cent). Although Estonians in Haabersti make up just 48.8 per cent, they are the largest group in the district (Russians constitute 4I per cent of Haabersti's population). In three districts - Kesklinn, Kristiine and Mustamäe - Estonians account for between 55 and 75 per cent of all residents. Nõmme (83.8 per cent) and Pirita (8I.6 per cent) are almost entirely populated by Estonians (TCG 2008).

Kohtla-Järve is an industrial town in the north-east with 45,093 inhabitants (SOE 2009). Some of the TIES project respondents, mostly Estonians, are also from Jõhvi, the industrial town near Kohtla-Järve with a population of II,549 (JMC 2009). Kohtla-Järve is one of the biggest cities in Ida-Virumaa County and Jõhvi is the administrative centre of the unit (see Figure 2.4). The combined Russian population of both cities accounts for about $\mathrm{I} 6$ per cent of the entire Russian minority in Estonia (SOE 2000).

The changes in Ida-Virumaa County were much more drastic than in Tallinn. Due to the vast amount of oil shale in the region, the Soviet government poured plenty of resources into the local economy. Kohtla- 
Figure 2.3 Map of Tallinn

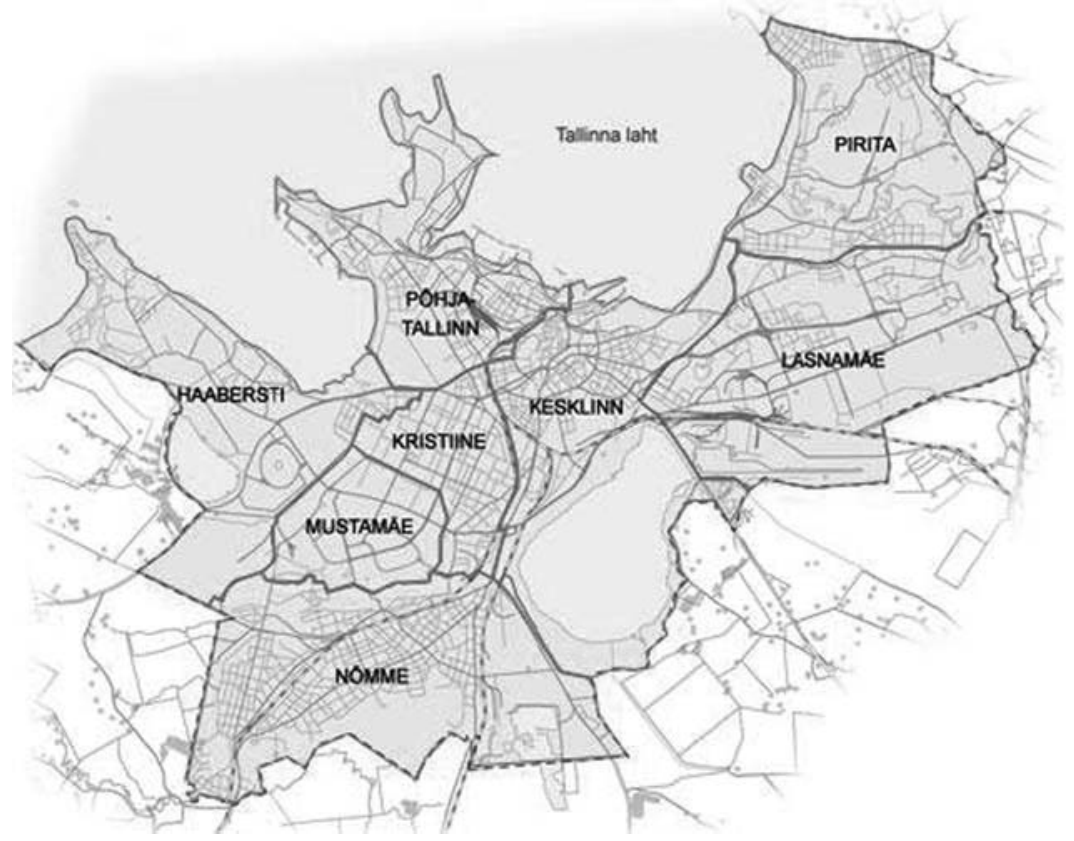

Source: www.tallinn.ee

Figure 2.4 Map of Ida-Virumaa

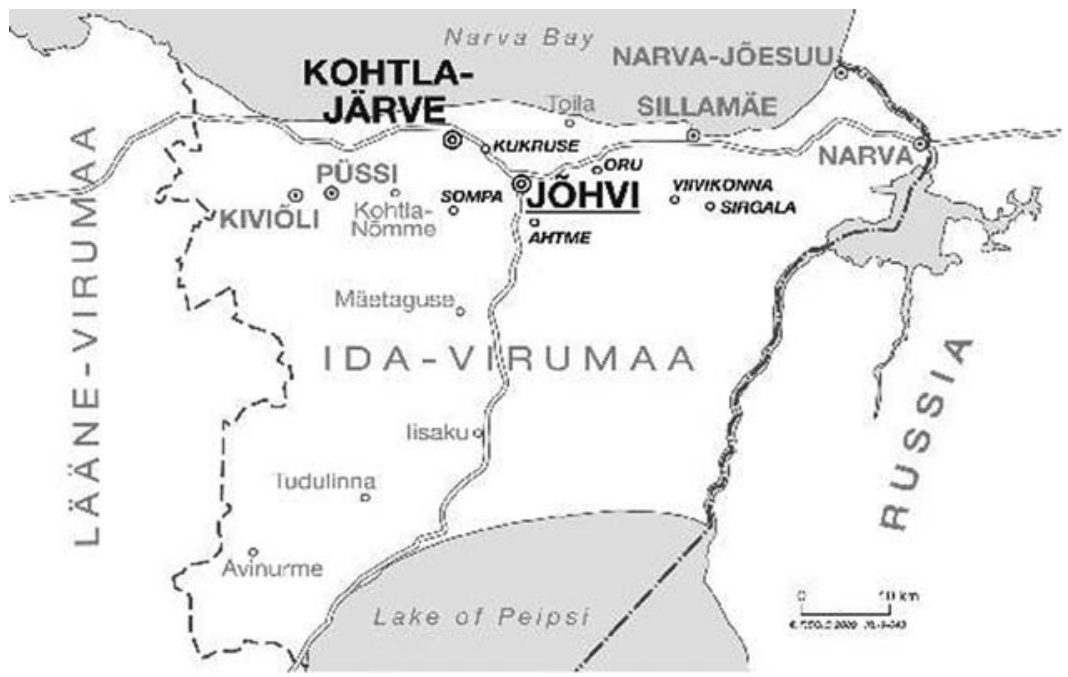

Source: AS Regio 
Järve was built during this period to accommodate the growing mining industry. The first migrant workers came to Ida-Virumaa right after the end of World War II and continued pouring in during the entire Soviet period. The urban population of the region grew considerably more than the average across the country. Although many people stayed, still more chose to move to other large cities. Among the reasons were the lack of employment possibilities outside the industrial sector and the worsening environmental conditions (Marksoo 2005). As a result of Soviet policies and increased mobility, the population of Kohtla-Järve reached 62,100 in I989. In Jõhvi there were 15,600 inhabitants in this year. In both towns, Russians outnumbered Estonians.

The loss of resources from Moscow and the subsequent collapse of big industries hit Ida-Virumaa County especially hard. Many residents moved to other parts of Estonia or left the country. In just twenty years, Kohtla-Järve lost 17,000 people or almost 30 per cent of its population, while Jõhvi decreased by 4,000 inhabitants or 26 per cent. The share of Estonians in Ida-Virumaa County remained low, at about 20 per cent (SOE 2009). Neither Kohtla-Järve nor Jõhvi display visible patterns of the possible segregation of Estonians and Russians according to where they live.

\subsection{Overview of the 2000 population census statistics'}

In 2000, Russians constituted 25.6 per cent of the country's population. In Tallinn, they made up 36.5 per cent; in Jõhvi, 53.5 per cent; and in Kohtla-Järve, 68.9 per cent. A little more than half of all Russians (58 per cent) were born on the territory of Estonia. In Tallinn those born in Estonia were 40.5 per cent, while in Ida-Virumaa the share was around 20 per cent (see Table 2.2). Naturally, there are fewer people born in Estonia among the older generation of Russians (Sokolova 2008). There are not only more Russians in the country's north-eastern region, but there are substantially more there who were born outside of Estonia.

About three quarters of all those non-Estonians ${ }^{2}$ born in the republic had at least one parent whose country of birth was not Estonia. About half of all non-Estonians stated that both of their parents were not born

Table 2.2 Share of Russians in population (in \%)

\begin{tabular}{lccc}
\hline & Population in general & Tallinn & Kohtla-Järve/Jöhvi \\
\hline Share of Russians & 25.6 & 36.5 & $68.9 / 53.5$ \\
$\begin{aligned} \text { Share of Russians } \\
\text { born in Estonia }\end{aligned}$ & 58 & 40.5 & 20 \\
\hline
\end{tabular}

Source: 2000 population and housing census, Statistical Office of Estonia 
in the republic (see Table 2.3). The vast majority (92 per cent) of other respondents, who were born outside Estonia, claimed that both their mother and father were not from Estonia. As of 2000, about half of all non-Estonians were first-generation immigrants; while the vast majority of the remaining half could be regarded as second generation (about one third of the group could be counted as third generation or descendants of the national minorities that lived in Estonia during the first independence).

Due to the citizenship law that established the predominance of the principle of jus sanguinis over jus soli, the majority of Russian inhabitants had to go through a naturalisation process in order to get Estonian citizenship. For a variety of reasons, many people decided not to do that, instead choosing one of the other available options - citizenship of the Russian Federation or undetermined citizenship. Consequently, about 40 per cent of Russians hold Estonian citizenship, 38 per cent have undetermined citizenship and about 2I per cent have Russian citizenship (for a more detailed explanation and more current statistics see Vetik in this volume). A breakdown of the cities produces the following results: about 7I.I per cent of Tallinn residents are Estonian citizens, while only 4I.8 per cent of those living in KohtlaJärve and 54.7 per cent in Jõhvi have Estonian citizenship (see Table 2.4). Of the other options available, both Tallinn and Ida-Virumaa inhabitants tend to choose undetermined citizenship over becoming Russian. So, for example, while 8.7 per cent of Tallinn residents were Russian citizens, I8 per cent had undetermined citizenship. In KohtlaJärve, the respective numbers were 13.4 per cent and 42.7 per cent; in Jõhvi, I3.3 per cent were Russian citizens and 30.I per cent of residents chose for undetermined citizenship.

Table 2.3 Place of birth and parents' place of birth (in \%)

\begin{tabular}{lcccc}
\hline & Estonia & Tallinn & Jöhvi & Kohtla-järve \\
\hline Census respondents born in Estonia & 49 & 50 & 48 & 54 \\
- at least one parent born outside Estonia & 76 & 78 & 75 & 73 \\
- both parents born outside Estonia & 47 & 49 & 49 & 46 \\
\hline
\end{tabular}

Source: 2000 population and housing census, Statistical Office of Estonia

Table 2.4 Distribution of citizenship (in \%)

\begin{tabular}{lccc}
\hline & Russians in Estonia & $\begin{array}{l}\text { Tallinn inhabitants } \\
\text { (mixed) }\end{array}$ & $\begin{array}{c}\text { Kohtla-Järve/Jõhvi } \\
\text { inhabitants (mixed) }\end{array}$ \\
\hline Estonian citizenship & 40 & 71.1 & $41.8 / 54.7$ \\
Russian citizenship & 21 & 8.7 & $13.4 / 13.3$ \\
Undetermined citizenship & 38 & 18 & $42.7 / 30.1$ \\
\hline
\end{tabular}

Source: 2000 population and housing census, Statistical Office of Estonia 


\subsection{Overview of the statistics on second-generation Russians in the TIES project data}

The TIES project data on the second-generation Russian immigrants in Estonia mostly parallels the general statistics (for more detailed information see the country report on the TIES survey in Estonia). However, there are some anomalies, largely due to the difficulties of recruiting respondents for the survey. Although the 2000 census puts the number of women as higher than the number of men (7 per cent for Estonians and II per cent for Russians), the percentage gap between genders for TIES respondents is much wider. Women accounted for almost three quarters of the Kohtla-Järve participants (see Table 2.5).

Although age distribution is more balanced compared to gender distribution, some younger Russian groups (those aged I9, 20 and 2I) are overrepresented in comparison to older groups of respondents aged 29, 30, 3I and 35 (see Figure 2.5).

About 28 per cent of the second-generation Russians' parents were born on the territory of Russia (see Table 2.6). Around 43 per cent of respondents indicated that neither of their parents was born in Estonia. The majority came from Russia. Of them, I6.6 per cent of mothers and I8.2 per cent of fathers were born neither on the territory of Estonia nor Russia, but rather in other former Soviet Union republics. Of them, 7.4 per cent of fathers and 5.7 of mothers originated from the Ukraine and around 5 per cent of parents came from Byelorussia.

The distribution of citizenship can be seen in Table 2.7. Tallinn residents are more likely to have Estonian citizenship and less likely to hold undetermined citizenship than inhabitants of Kohtla-Järve and Jõhvi. The percentage of Russian citizenship holders is almost equal in all three places of residence. The breakdown according to gender shows that females are about 5 per cent more likely to hold Estonian or Russian citizenship, while the same percentage of males is more likely to have undetermined citizenship.

Table 2.5 Gender distribution by city of residence and ethnic group in TIES project (in \%)

\begin{tabular}{llccc}
\hline City of residence & Gender & \multicolumn{2}{c}{ Ethnicity } & Total N \\
\cline { 3 - 4 } & & Russian & Estonian & \\
\hline Tallinn & Male & 37.7 & 31.1 & 158 \\
& Female & 62.3 & 68.9 & 306 \\
Ida-Virumaa & Male & 27.5 & 36.8 & 169 \\
(Kohtla-Järve and Jöhvi) & Female & 72.5 & 63.2 & 367 \\
\hline
\end{tabular}

Source: Country report on TIES survey in Estonia 
Figure 2.5 Age distribution of the TIES project respondents

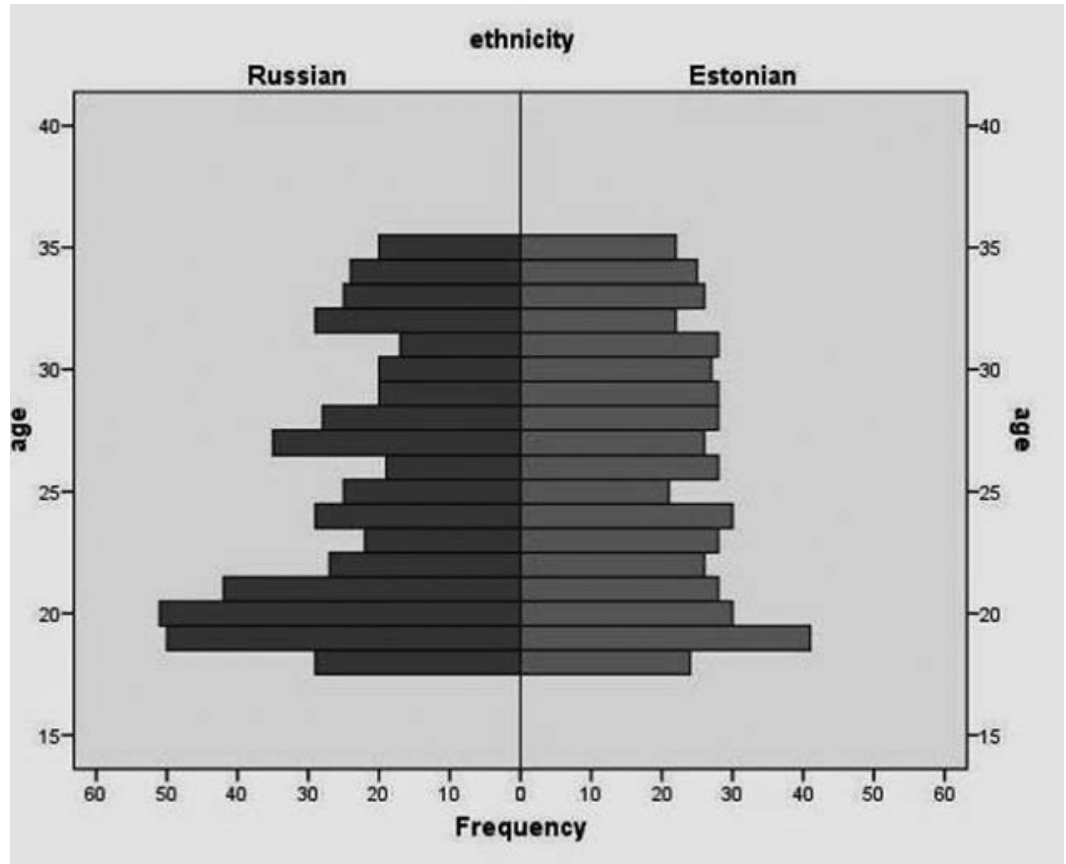

Source: Country report on the TIES survey in Estonia

Table 2.6 Parents' country of birth in TIES project (in \%)

\begin{tabular}{llccccc}
\hline & & \multicolumn{3}{c}{ Mother } & Total \% & Total N \\
\cline { 3 - 5 } & & Estonia & Russia & Other & & \\
\hline Father & Estonia & NA & 19.9 & 8.2 & 28.3 & 145 \\
& Russia & 21.1 & 27.5 & 4.1 & 52.7 & 270 \\
& Other & 6.8 & 7 & 4.3 & 18.2 & 93 \\
Total \% & & 27.9 & 54.4 & 16.6 & 99.2 & \\
\hline
\end{tabular}

Source: Country report on TIES survey in Estonia

Table 2.7 Distribution of citizenship by city of residence among Russians in TIES project (in \%)

\begin{tabular}{lrccr}
\hline Citizenship & \multicolumn{2}{c}{ City of residence } & Total \% & Total N \\
\cline { 2 - 3 } & Tallinn & Kohtla-Järve and Jõhvi & & \\
\hline Estonian & 68.4 & 50.5 & 57.8 & 294 \\
Undetermined citizenship & 20.9 & 35.6 & 29.7 & 152 \\
Russian & 9.2 & 10.6 & 10 & 51 \\
Other & 1.5 & 3.3 & 2.5 & 12 \\
\hline
\end{tabular}

Source: Country report on TIES survey in Estonia 
Table 2.8 Responses to question concerning parents' citizenship in TIES project (in \%)

\begin{tabular}{|c|c|c|c|c|c|c|}
\hline \multirow{2}{*}{\multicolumn{2}{|c|}{$\begin{array}{l}\text { ‘Does your father/mother } \\
\text { have Estonian citizenship?' }\end{array}$}} & \multicolumn{3}{|c|}{ Mother } & \multirow[t]{2}{*}{ Total \% } & \multirow[t]{2}{*}{ Total N } \\
\hline & & Yes & No & Don't know & & \\
\hline \multirow[t]{3}{*}{ Father } & Yes & 19.7 & 5.1 & 0.2 & 25 & 128 \\
\hline & No & 18.6 & 45.5 & 1.4 & 65.4 & 335 \\
\hline & Don't know & 3.9 & 4.3 & 1.2 & 9.4 & 48 \\
\hline \multicolumn{2}{|l|}{ Total \% } & 42.2 & 54.9 & 2.7 & 100 & 511 \\
\hline
\end{tabular}

Source: Country report on TIES survey in Estonia

The TIES project respondents are more likely to be Estonian citizens and much less likely to be Russian citizens compared to their parents. When it comes to a more detailed observation of parents' citizenship, mothers are more likely to have Estonian citizenship than fathers (see Table 2.8). About one fifth of TIES respondents have two parents with Estonian citizenship. Among the couples that have just one Estonian citizen, it is more likely to be the mother than the father. Both mothers and fathers without Estonian citizenship are more likely to live in IdaVirumaa than in Tallinn. One possible explanation for why a larger percentage of women hold Estonian citizenship compared to males is the knowledge of Estonian language: 52.8 per cent of mothers who are Estonian citizens speak Estonian very well, well or satisfactorily. The percentage for fathers is 44.4 per cent.

The question about Estonian language skills in both the census questionnaire and in the TIES project presupposed self-evaluation. Although the percentage of those that claim to have very good Estonian language skills is higher among Tallinn Russians, Ida-Virumaa inhabitants claim more frequently than their counterparts in the capital to have a good knowledge of the language. Russians from Kohtla-Järve and Jõhvi tend to categorise themselves as having a moderate or poor command of Estonian more often than Tallinn inhabitants. Unfortunately, differences in the questions do not allow for a comparison of the language skills statistics and the census data.

\section{Notes}

I All the information in this section, unless specified otherwise, is derived from the census available on the website of Estonian Statistical Office (http://pub.stat.ee/pxweb.200I/Database/Rahvaloendus/databasetree.asp).

2 Available data on the country of birth of respondents' parents only offers a distinction between Estonians and non-Estonians, with no specification of particular ethnic groups. 


\section{References}

CMB (Citizenship and Migration Board) (2009), Statistics. www.mig.ee/index.php/mg/ eng/statistics. Accessed I November 2009.

ESO (Estonian Statistical Office) (2009), Statistics. www.stat.ee. Accessed 25 September 2009.

Hallik, K. (I998), 'Eestimaa muulased: Ajalooline ja demograafiline taust', Vene küsimus ja Eesti valikud. Tallinn: TPÜ RASI, TPÜ kirjastus.

JMC (Jõhvi Municipal Council) (2009), Statistics. www.johvi.ee/sites/default/files/failid/ statistika/statistika_2009_07_oI.pdf. Accessed 2 January 20 Iо.

Katus, K. \& L. Sakkeus (I993), Foreign-born population in Estonia. RU Series B, No. I9. Tallinn: EKDK.

Katus, K., A. Puur \& A. Põldma (2005), Rahvastiku ühtlusarvutatud sündmus- ja loendusstatistika. RU Series C, No. 25. Tallinn: EKDK.

Kulu, H. (I998), Eesti välissündinud rahvastiku kujunemine ja rändelugu. RU Series B, No. 38. Tallinn: EKDK.

Kulu, H. (200I). 'Sõjajärgne sisseränne Eestisse võrdlevas perspektiivis', Akadeemia II (I52): 2379-2395.

Kulu, H. \& F.C. Billari (2004), 'Multilevel analysis of internal migration in a transitional country: The case of Estonia'. Regional Studies 38 (6): 679-696.

Marksoo, A. (2005), 'Linnastumine ja ränne nõukogude perioodil', in H. Kulu \& T. Tammaru (eds.), Asutus ja ränne Eestis. Uurimusi Ann Marksoo 75. Sünnipäevaks, 59-8I. Tartu: Tartu Ülikooli Kirjastus.

OMPEA (Office of the Minister for Population and Ethnic Affairs) (2009), Main principles of population policy. www.rahvastikuminister.ee/? $\mathrm{id}=\mathrm{I} 2392$. Accessed I3 October 2009.

Sakkeus, L. (I99I), Post-war migration trends in Estonia. RU Series B, No. I5. Tallinn: EKDK.

Sakkeus, L. (I999), 'Migratsioon ja selle mõju Eesti demograafilisele arengule', in J. Viikberg (ed.), Eesti rahvaste raamat, 310-325. Tallinn: Eesti Entsüklopeedia Kirjastus.

Sjöberg, O. \& T. Tammaru (I999), 'Transitional statistics: Internal migration and urban growth in post-Soviet Estonia', Europe-Asia Studies 5I (5): 82I-842.

SOE (Statistical Office of Estonia) (1995), Population of Estonia by population censuses. www. stat.ee/20408. Accessed io July 2009.

SOE (Statistical Office of Estonia) (2000), 2000 Population and housing census. pub.stat.ee/ px-web.200I/Database/Rahvaloendus/databasetree.asp. Accessed 5 July 2009.

Sokolova, N. (2008), 'Demography', in Integration of second-generation Russians in Estonia. Country report on TIES survey in Estonia, 8-2I. Tallinn: Institute of International and Social Studies, Tallinn University.

TCG (Tallinn City Government) (2008), Tallinn arvudes 2007: Statistical Yearbook of Tallinn 2007. Tallinn: Tallinna Linnavalitsus (Tallinn City Government). 


\title{
3 Integration policies
}

\author{
Raivo Vetik
}

\subsection{Introduction}

This chapter discusses integration policies in Estonia. The introduction outlines the main lines of the debate on Estonian integration policies in academic literature. The second section specifies the main challenges of generic integration policy in Estonia, as compared to other integration policies in countries in Europe countries facing similar issues. The third section is devoted to conceptualising the Estonian integration model by locating it within the context of debates regarding the relationship between individual and group rights in liberal social theory. The fourth section analyses the primary documents of the integration strategy, adopted by the Estonian government in the period I998-2008, in the theoretical perspective of the previous sections. The aim of this chapter is not to provide a detailed description of the concrete integration measures implemented by government agencies but rather, to conceptualise these measures within broader historical and theoretical contexts. Such an approach connects this chapter to others in the volume in order to elucidate the social processes scrutinised within them.

Two different trends can be identified in the academic literature on Estonian integration policy. One trend is based, largely, on the theoretical presumptions of procedural liberalism; the other is based on the concept of nation building. A good example of the latter is the approach taken by Estonian scholars Marju Lauristin and Mati Heidmets in their edited volume The challenge of the Russian minority. The authors claim:

Majority-minority relations are inevitably elements in the broader process of development and change of the whole society. In Estonia, this means that inter-ethnic relations should be seen as a part of the post-Communist transformation, including many dimensions: privatisation, creating a new legal system, introduction of market relations, etc. Establishing a new pattern in the interethnic field is inseparable from other dimensions of transformation, and sometimes it is quite complicated to differentiate the purely inter-ethnic aspects and issues from other aspects of social transformation. (Lauristin \& Heidmets 2002: 24) 
The authors' position regarding the progress made in the Estonian integration policy is expressed in their assumption that:

the historical need to define the position of the Estonian nation concerning the position and future of the new Russian minority in the country has accelerated the transformation of Estonia from an ethnic nation (characterised by the historically dominant position of defensive nationalism) to a modern civic nation. (ibid.: 20)

However, such optimism is not shared in mainstream literature on Estonian ethnopolicy, which is rather critical. The critical trend is represented, for example, by the work of such authors as Malte Brosig (2008), Gregory Feldman (2003a, b, 2005a, b, 2008), David Laitin (2003) and Vello Pettai and Klara Hallik (2002). Brosig (2008) has offered a thorough overview of the formation of Estonian integration policy following the restoration of independence. He holds that:

although its theoretical basis is well grounded, the programme does not account for minority integration needs systematically. Instead, it follows a unidirectional action-plan, targeting Russian speakers without a prior needs-assessment at grass-root level and insufficient minority participation during the drafting and implementation period. (ibid.: I)

In addition, Brosig highlights 'the influence the legal-restorationist concept maintains on the implementation of the State Integration Programme, which partly has the effect of re-enforcing inter-ethnic alienation'.

Feldman regards ethnopolicy in Estonia during the period after regaining independence mostly as a power strategy of ethnic Estonians. He locates the State Integration Programme within the broader context of international affairs, demonstrating how the invocation of national security concerns justified the denial of citizenship to Soviet era Russian speakers and incorporating the concept of the 'Estonian cultural domain' into the integration programme (Feldman 2005a: 676). Laitin's broader and more balanced account of ethnopolicy in Estonia regards the State Integration Programme as an outcome of four different factors: the domestic political reality of party competition; the need to satisfy Europe in the process of EU accession; an economic need for trade relations with Russia; and the desire of the Estonian political class to provide a public good (Laitin 2003).

Estonian scholars Pettai and Hallik also represent the critical trend and summarise their understanding of ethnopolicy in Estonia as follows: 
We argue first that Estonian moves to restrict automatic citizenship after I99I to only pre-I940 citizens in I940 and their descendants represented an essential opening step toward segmentation of the non-Estonian minority. Secondly, economic changes in the country as a result of market transition altered considerably the economic resource base of both the Estonian and the non-Estonian communities. Here the net effect was a considerable increase in the dependence of the latter on the former. Lastly, we examine the extent to which the Estonian political elite has practiced a policy of co-optation among key non-Estonian leaders. For example, during I992-I993 some of these efforts were especially transparent. However, even in the more recent case of the Estonian government's 'State Integration Programme', we argue that the aim is still to help non-Estonians join an Estoniandefined nation-state. (Pettai \& Hallik 2002: 506)

Although the authors acknowledge that 'to call this programme "co-optation" may seem excessive' (ibid.: 520), they argue that the emphasis on the Estonian language as the key to integration is a confirmation of an ethnic control approach to integration (ibid.: 524).

\subsection{The challenges of a generic integration policy in Estonia}

Integration, by nature, is a contradictory process that includes the shared component of those integrating on the one hand, and their differences on the other. Thus, one of the central conceptual challenges in defining meaningful integration policy is finding a way to combine various aspects of unity and difference in society. This combination varies in different integration ideologies, depending on historical, economical and cultural factors, as well as everyday politics in the respective country. The uniqueness of the Estonian situation, in comparison with most other European countries facing the integration issue, stems from the formation of two parallel societies - Estonian and Russian - during the Soviet era, which were comparable in size. Many Estonians perceived the Russian population as the dominant ethnic group in the Soviet Union, and as being more affiliated to the power structures and having certain privileges, compared to other ethnic groups. Russians in Estonia, on the other hand, perceived themselves as not being part of the local society, into which they should integrate, but rather, the Soviet Union as a whole. From the Russians' perspective, the burden of integration was on the side of the Estonians. Such a state of affairs has led to deep ethnic segmentation of the two groups, even within those social institutions that traditionally unify society in modern nation states. 
Thus, the main challenge of the Estonian integration policy after regaining independence has been finding a new equilibrium between national unity and difference in the context of deeply segregated society.

Achieving such equilibrium presumes implementation of generic integration policies, which would lead to the formation of a common public sphere in Estonia, accepted by all members of society, regardless of ethnicity. However, the two language communities possess very different views on the unity of the public sphere in Estonia. The Russianspeaking community tends to understand the state policies undertaken after regaining independence as attempts to assimilate minorities, rather than providing equal opportunities for the both groups. Many Estonians, on the other hand, tend to consider the policies as a rejection of nation-state ideals (Vetik 2007). Both positions stem from a deeply rooted sense of threat (see Lake \& Rothchild 1998), which results from the policies carried out in the Soviet period on the one hand, as well as in the newly independent Estonian Republic, on the other. What makes the Estonian case specific is the fact that threat perception is widespread, not only among minorities but also among the titular group, which results from both the Soviet past and regular conflicts in the current Estonian-Russian relationship.

Generally, there are four types of conflicting understandings of generic integration policies in Estonia. The first type relates to the issue of citizenship: Estonia's independence was restored according to the principle of legal continuity, and therefore only pre-Soviet era citizens and their descendants were offered automatic citizenship. People that migrated to Estonia during the Soviet era had to go through a naturalisation process, one element of which involved demonstrating knowledge of the Estonian language. A large proportion of the Russian population did not have this proficiency at the time the citizenship law was passed, and for several reasons did not acquire it later. Consequently, they either remained without citizenship or became citizens of Russia. The Citizenship Act passed in 1992 and the subsequent Aliens Act of I993, both based on this model, clearly strengthened Estonians' sense of security towards their future. However, these laws also created a feeling of injustice among the Russian community. Currently, only about a half of Russians have Estonian citizenship, and about the same proportion have either undetermined citizenship or are citizens of Russia. Regular integration monitoring, carried out since the year 2000, confirms that the attitudes of the Estonian and Russian communities differ in terms of finding a solution to the citizenship problem. The majority of Estonians, for example, approve of the current citizenship policy, whereas most Russians regard it as discriminatory (Nimmerfeldt 2008). 
The second source of conflicting framings relates to the Estonian language. Defining Estonian as the country's only official language, and broadening its scope of application both geographically and professionally, has been a primary goal of the generic integration policy of the Estonian state since regaining independence. However, because Russian was the language of communication between different ethnicities during the Soviet period, many Russians regard the issuing of special rights to the Estonian language as a limitation of their own rights, as well as a threat to the survival of the Russian language in Estonia. In addition, in the many areas of Ida-Virumaa that are mostly inhabited by the Russian-speaking population, acquisition of the Estonian language at a sufficient level remains unrealistic, as many people lack the vital need or desire to learn it, and the language environment is not conducive to sustaining knowledge of Estonian. As a result, many Russians consider Estonia's language policy not in the framework of integration but rather, as administrative pressure from above. Moreover, the imposition of the Estonian language through such policies escalates their sense of threat and evokes a reactive identity, which is expressed through opposition towards any kind of policies, even those targeted towards improving the opportunities of the Russian language minority (Vetik 2007).

The third type of conflict stems from the need to reform several social institutions after the restoration of independence and, inevitably, to dismantle the old ones. The foundation of a unitary education system, for example, presupposes the abolition of the parallel school systems established during the Soviet era. From the standpoint of the Estonian state, a unified education system would provide more equal career opportunities to the entire youth, regardless of their ethnicity. In all European nation-states, standardised schooling has historically been the main instrument for forming a unified 'demos' and for promoting equal opportunities among different social groups. However, as a result of the separate school systems established in Estonia during the Soviet time, the ongoing school reform is not viewed as a compromise towards unifying the two systems but rather, as an attempt at assimilation and the establishment of an ethnic nation-state. Consequently, many Russians possess an a priori negative attitude towards the reform (Saar 2008).

Finally, the Estonian population is also split by the different attitudes regarding policies towards several external actors, particularly Russia. For many Estonians, Russia not only embodies the injustice of the past but also a continuous security threat. By contrast, most Russian speakers regard Russia as a source of their traditions and culture, as well as an information space, framing their daily life (Vihalemm 2008). This phenomenon reproduces a fragmentation of the public sphere of 
Estonian society daily. The escalation of the confrontation in the Estonian-Russian relationship in the course of recent years, and particularly the April 2007 crisis related to the removal of the Bronze Soldier from downtown Tallinn, reveals the external security threats of such a cleavage. Sadly, this split has become an essential feature of the internal power politics in Estonia and is exploited for electoral gain, further amplifying the fragmentation in the public sphere (Ehala in press).

The described conflicts and threat perceptions reveal that not only the problems of the present need to be addressed in current Estonian integration policy but also the problems of the past, which carry a tinge of a post-colonial connotation (Kuzio 2002). To recapitulate, the main features of the context of integration policy in Estonia are: the formation of two parallel societies, comparable in size, during the Soviet period; the partial parallelism in the legal statuses of the two communities, which formed after the restoration of Estonia's independence; minority reactivity towards the formation of a unified public sphere in Estonia through language and education policies; and the complex relations with neighbouring Russia, the cultural and informational space which, in many ways, the Russian community still inhabits. As a result, issues related to collective memory and the relationship between ethnic and national identity take on a considerably larger, and a much more important, role in shaping understanding of the public sphere and the integration issue in Estonia, than in most other European states facing the integration issue. According to Milton Gordon's classical scheme, identificational assimilation represents the last stage of migrants' adaptation, following on from structural and societal integration (Gordon I964). However, in the Estonian case, identity is, from early on, a central realm of integration, influencing all other integration areas. In other words, the most problematic issues of national integration in Estonia are not so much in the structural but in the cultural domain, embodied by the notion of mutual insecurity and the cultural threat.

This is not to suggest that structural integration is not a problem in Estonia. On the contrary, the data suggests that if the socio-economic positions of the Estonian and Russian communities were equal when independence was restored, then disparity has been growing exponentially ever since and in the case of salaries, reaching the level of 20 per cent by 2007 (Leping \& Toomet 2008). Integration as a socio-economic issue has only emerged in the course of the past few decades. Therefore, it can be claimed that both the starting positions, as well as latter dynamics of cultural and structural integration processes, are rather different in Estonia compared to most other European states. 


\subsection{Conceptualising the Estonian integration issue}

The elaboration of the national integration strategy, launched by the Estonian government in the second half of the I990s, also dwelled on the central role of cultural adaptation by immigrants. In preparing the integration strategy, it was assumed that Estonia is undergoing two phases of modernisation simultaneously (Vetik \& Ruutsoo I999). On the one hand, a nation-building process, halted during the Soviet period, was to continue, with the goal of creating and reinforcing a unified public sphere that is characteristic to modern society. On the other hand, Estonia has become a part of the postmodernising world, which would presume formation of new mechanisms to achieve national unity, such as a higher level of tolerance towards the cultural diversity needed for the existence of a common public sphere in the context of growing multiculturalism (Castells I997).

In the literature, there are two opposing assessments of modernisation, which emphasise either national unity or cultural diversity. The first trend regards the homogenising tendencies of nation-building policies as essential in modern condition and presumes that homogenisation should also touch the ethnic make-up of society, along with other social structures. This theoretical perspective views the dissolution of ethnic minorities into the dominant group not only as historically inevitable but also as beneficial - not least for minorities. Karl Deutsch, a classical proponent of this position, argued that the purpose of nation building is to merge culturally and linguistically different social groups into a congruent whole, by developing new loyalties and identities at the national level. Deutsch saw successful homogenisation and 'nationalisation' of society as a precondition for economic and societal development in any successful modernising state (Deutsch I963).

The opposite trend in literature advocates the preservation of ethnic and cultural differences in the modern world. For example, a leading opponent of the homogenisation model, Walker Connor, argues strongly against eradicating cultural differences by force in the process of national integration. According to Connor, advanced means of communication and transportation increase the cultural awareness of minorities and develop their self-consciousness. Consequently, attempts to force minority assimilation will inevitably bring about increased social conflict and separatist tendencies. He concludes that a balance between homogenisation and differentiation processes is necessary in modern nation-states (Connor 1972).

As a result of the two simultaneous macro-historical processes described above, the Estonian integration policy needs to meet the aims of different historical epochs. However, such internal controversy characterises not only Estonia but also most other European states, as the core 
political structures of current nation-states were established in an historical condition remarkably different from the one of today. Democracy and nationalism, despite their conceptually different underpinnings were, initially, not competitive but rather complementary ideologies, opposing the social hierarchies of the preceding historical epoch (Smith I99I). However, the rapid globalisation of the past few decades has put pressure on nation-states to redefine the relationship between political institutions and nationalism, as their societies have become considerably more multicultural compared with previous times (Kymlicka 1995).

In other words, Western states are based on democratic principles, but explosive growth of cultural heterogeneity in their societies during the past several decades has created problems for the traditional liberal democratic model. In literature, these issues are usually discussed in terms of the relationship between individual and group rights. Procedural and substantive forms of liberalism have been differentiated in this regard (Dworkin I977; see also Taylor 1994). The procedural approach is founded on Kant's principle of autonomy, according to which each individual has the right to define for oneself the concept of good. As this differs from person to person, then, deriving from the autonomy principle, the state should not formulate substantive positions for individuals to follow. Such an individualistic moral philosophy is based on Kantian epistemology, which aims to achieve in the social sciences the same kind of scientific truthfulness found in the natural sciences. As substantive claims about human and social affairs cannot be universal, the only option for achieving scientific truthfulness is a formalistic approach. The formalistic approach is based on the abstract notions of the individual, as well as society, such as the 'subject' and the 'universal state' of Kant. The coexistence of different cultures in the state is problematic in such a theoretical framework. The famous statement by John Stuart Mill that 'democracy is close to impossible in societies where there are different ethnic groups and divisions' illustrates this well.

The substantive form of liberalism, on the other hand, is founded not on the abstract notions of the individual or the universal state but on the ideas of historical societies and their group rights. Such an approach grew out of opposition to the inability of traditional liberalism to conceptualise majority and minority relations adequately in the context of the rapid expansion of multiculturalism during the past decades. The substantive model does not deny individual rights as a conceptual basis for liberalism; however, it attempts to link these with group rights, by recognising the possibility of essential ties between culture, language and territory. This link, and the idea of group-specific rights deriving from it, tends to become topical in conditions where a group perceives its cultural survival as threatened. For example, the attenuation of one's 
language space could decrease the respective group members' possibilities for success in society. Avoiding this could be, also from the standpoint of liberalism, one of the substantive goals a group is entitled to strive for (Kymlicka I995).

Quebec is an example of the substantive model. It is a society with both strong collective goals and liberal values. According to Charles Taylor (I994: 39), 'it is axiomatic for Quebec governments that the survival and flourishing of French culture in Quebec is a good'. On the other hand, Quebec has also established adequate safeguards for the fundamental rights of liberal ideology. It is clear that pursuing individualist and collectivist objectives simultaneously brings tensions and difficulties, but 'such a pursuit is not impossible, and the problems are not in principle greater than those encountered by any liberal society that has to combine, for example, liberty and equality, or prosperity and justice' (ibid.). Like Quebec, close connections between culture and territory are deeply rooted in the Estonian ethnic identity as well (Tamm 2008). The smallness of the Estonian nation, along with its geopolitical location and tragic historical experience, are usually noted as the main factors for Estonia's vulnerability and the threat to its long-term survival (Hiio 2007). This is the dominant discourse behind the fact that the I992 Constitution defines the Estonian language and culture as something the state should stand for.

The same kind of reasoning was applied when incorporating the concept of group-specific rights of ethnic Estonians into the integration strategy (Vetik 200I). There is, however, another aspect to the recognition of group rights, which has to do with minorities: should minorities be acknowledged as a cultural subject, or as a political group with specific rights? The literature on Estonia reveals two opposing approaches in this respect, both based on the acknowledgement of the existence of threats to the minority or majority group, as well as the need to deal with these threats. Juan Linz and Alfred Stepan support the political group rights model, which acknowledges the endangered status of minorities, as well as the possibility to manage this through certain political institutions. These authors believe that the solution to the Estonian integration issue is in declaring minorities as political groups with collective rights, such as the possibility to establish territorial autonomy and a bilingual public sphere (Linz \& Stepan I996). Heidmets and Lauristin oppose this approach, however, perceiving the ethnic Estonian group as threatened. Consequently, they offer the model of immigrants' individual cultural identification as a possible solution to the integration issue in Estonia. They argue that the population that migrated to Estonia from other republics of the Soviet Union under the Soviet occupation does not form a national minority, but represents an immigrant group, whose members should be assured equal 
opportunities in society, as well as possibilities to preserve their cultural heritage. Such a model does not acknowledge the collective political rights of minorities, but cultural pluralism in the framework of common societal cultural space (Heidmets \& Lauristin I998).

This concept originates from Will Kymlicka, who differentiates between two types of minority groups, immigrants and national minorities, and respective group rights (Kymlicka I995). The national minorities form a fully fledged society in their historical homeland before they are united with the larger nation-state during the modernisation process. Examples include Native Americans or Finnish Sami. Immigrants, on the other hand, are those groups who have migrated to another state either for economic or political motives, such as the Turks in Germany or the Pakistanis in Norway. According to Kymlicka, national minorities are entitled to the same group rights as the titular nation. This includes political rights. The rights of immigrant groups, however, should be restricted to maintaining their language and culture. Even though Estonia represents an intermediate case in the framework of this model, as Russian language minorities represent neither a pure immigrant group nor a complete national minority, Kymlicka recommends that Estonia apply the immigrant group model in its integration policies (Kymlicka 2000).

\subsection{The main integration policy documents}

The two national institutions responsible for the coordination of the integration policy in Estonia are the Minister of Population Affairs and the Integration Foundation, founded in 1997 and I998, respectively. ${ }^{\mathrm{I}}$ This section will analyse the key documents of the Estonian integration policy, drafted by these institutions, in the context of the theoretical issues outlined above. ${ }^{2}$ The development of the integration policy is represented in the following governmental policy documents: The Action Plan for Integration of Non-Estonians into Estonian Society (Ministry of Population and Ethnic Affairs (MPEA) I999), The State Programme: Integration in Estonian Society 2000-2007 (MPEA 2000) and The Estonian Integration Strategy 2008-2013 (2008). The focus of this section will be on the integration programme of 2000-2007, in which the conceptual issues of the relationship between national unity and cultural difference have been elaborated most thoroughly (Vetik 200I). In the integration strategy of 2008-20I3, the previous conceptual approach remained unchanged.

The action plan, adopted in March 1998, represented an important step in Estonian integration policies. There were both external and internal factors behind this step, including the need to conform to the 
European standards in the process of EU accession, and an emerging understanding among Estonia's political and academic elite about the counterproductive consequences of the exclusive approach adopted to that point. Thus, whereas during the previous period the dominant belief was that the restoration of the Estonian nation-state presumes the return of Russians to their historical homeland, this strategy declared a new orientation towards the integration of Russians into Estonian society. This included a significant reduction in the number of people with undetermined citizenship, a substantial breakthrough in teaching the Estonian language and the active participation of Russians in Estonian society. In addition, the strategy aimed at changing the attitudes among Estonians, i.e. the replacement of the concept of Russians as a 'problem' with the concept of Russians as a 'resource'. The strategy placed an emphasis on children and youth, making the Estonian education system the central integration agent. Likewise, the strategy aimed at reducing the regional isolation of Russians and removing the barriers hindering Russian competitiveness in the labour market and public life (MPEA I999).

Thus, the action plan of 1998 marks a remarkable discursive shift from an ethnocentric to a more balanced approach towards ethnic diversity in Estonia. However, the plan includes a number of conceptual problems. For example, the strategy introduces the concept of the Estonian version of a multicultural society, which includes three elements: centrality of the individual, a strong common ground in the public sphere, and the dominance of Estonian culture. The notions of the centrality of the individual and Estonian cultural dominance derive from different conceptual paradigms, as described above. The principle of centrality of the individual, as it is defined in the strategy, denies the concept of group rights for minorities, while the principle of Estonian cultural dominance explicitly recognises the group rights of the majority. Thus, the element of the model describing the position of minorities is based on the procedural, while the element describing the position of the majority is based on the substantive model of liberal society. This and several other contradictions in the strategy have resulted in it being strongly criticised in academic literature. For example, Hanne-Margret Birckenbach (I998) states that:

The concept launched by the Estonian government prolongs the ethnic orientation of Estonian nation-building. It is based on ethnic priorities rather than on republican considerations. It aims at defending the ethnic dominance against international demands for equality. 
However, her conclusion has an important qualification - the very process of launching the integration strategy and exposing it to criticism facilitates the integration of Estonian society.

In this context, the adoption of the state programme Integration of Estonian Society 2000-2007 in March 2000, which was accompanied by a detailed action plan, represents an important new step in Estonian ethnopolitical thinking. Already, the name of the programme refers to an essential conceptual change. Whereas the integration strategy of I99 8 uses the notion of integration of Russians into Estonian society, the integration programme $2000-2007$ recognises integration as a twoway process, which presumes a role for both Russians and Estonians. In the new programme, integration is defined as a contradictory process designed to find a proper balance between national unity and difference. This definition originates from the conceptual debates, described above, about individual and group rights in multicultural societies, as well as the need to overcome the mutual sense of threat.

The essence of Estonian society's integration is shaped by two processes: the societal unification on the one hand, and the preservation of ethnic difference through recognizing the cultural rights of ethnic minorities, on the other. The unification of Estonian society, therewith, is a two-way process - the integration of Estonians as well as Russians around a strong common ground within society. (MPEA 2000)

The aims of integration with regard to different target groups have been phrased differently in the programme. Integration is understood as a two-way process, presupposing an effort also on behalf of the majority group:

In case of the Russian target group, integration is expressed in the gradual decrease of barriers which at the moment hinder many Russians' competitiveness in Estonian labour market as well as their participation in local education possibilities, involvement in local cultural and political life. Those barriers are mainly related to fears and prejudices connected to the levels of the skills of Estonian language or acquaintance with the local culture, their legal status as well as rapid changes in the society. Regarding the Estonian target group, integration manifests itself through an attitude change with an aim to establish an open and socializing environment. (MPEA 2000)

This definition of integration gives an idea of the relationship between national unity and cultural difference on a general conceptual level. 
Translation of the conceptual model into concrete integration policies presumes, however, describing the desirable relationship between unity and difference within specific integration domains as well. This translation has been undertaken in two analytically different steps in the integration programme. The first step has been taken along the lines of John Rex's multiculturalism theory, which is based on a differentiation between the public and private spheres (Vetik 200I). According to Rex, in order to understand multiculturalism as a form of social order, it is important to explore how unitary or different the main ethnic groups are in the two spheres, as well as what kind of policies the state is practicing within each of them. By intersecting the two dimensions analytically, four logical possibilities emerge: a) a society that is unitary in the public sphere but tolerant to difference in the private sphere; b) a society that is unitary in the public sphere and promotes unity in the public sphere as well; c) a society that enhances difference and different rights in the public, as well as in the private sphere; d) a society that promotes difference and different rights in the public sphere, but similarity in the private sphere. According to Rex (I996), variant a represents the model of multiculturalism, $\mathrm{b}$ is the assimilation model typical of France, $\mathrm{c}$ is typical for colonialism and d describes the US southern states before the civil rights movement.

The described model presumes that in a multicultural society, the private sphere should be organised according to the principle of difference, while the public sphere should be based on the principle of unity. However, Rex also shows that some social phenomena exist in both spheres at the same time. Education, for example, gives people instrumental competence important in the labour market. In that sense it belongs to the public sphere, however, it also teaches moral values and historical events important for a particular culture, and therefore belongs in the private sphere. The same is true of language. On the one hand, a common language is vital for communication. On the other hand, it is also a vehicle for transmitting the values and mentality specific to a particular culture. The private and public spheres therefore can be differentiated analytically, but in reality, they are often interconnected.

In formulating an integration model, a decision must be made, as to what exactly should belong in a society's public sphere, i.e. in which proportion the elements deriving from either the majority culture or the culture of the minorities should be represented. Figure 3.I describes the choices made in the Estonian integration programme. It describes the integration model of the Estonian society, which is defined by three concepts specifying the relationship between the individual and collectives rights described above: strong common ground in the public sphere; support for a fully fledged Estonian cultural space; and support 
Figure 3.1 The Estonian model of multiculturalism

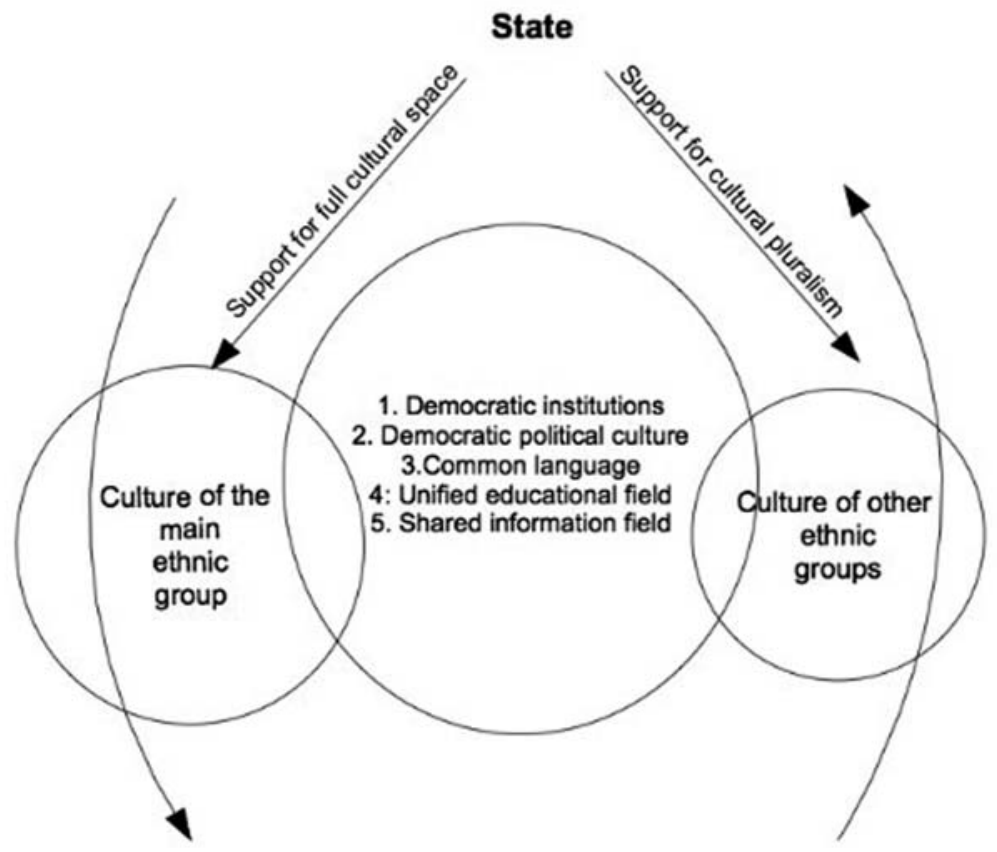

Individual

Source: Composed by author

for the cultural pluralism of minorities. The cultural pluralism of minorities is defined in the integration programme as assuring possibilities for the preservation of both the language and cultural uniqueness of Russians. Primarily, these possibilities should come in the form of providing some education in their mother tongue, as well as by supporting their cultural societies. Thus, the goal of integration is the cultural adaptation of different ethnic groups within Estonian society, not their assimilation into the Estonian culture. A concrete example of an element from the minority culture, which belongs to the public sphere, is the possibility of using the minority language in local government, in cases where the minority constitutes over 50 per cent of the region's population.

Furthermore, support for a fully fledged Estonian cultural space denotes the idea that the status of Estonian culture is different to the 
status of minority cultures in Estonia. The state supports minority cultures but the common public sphere in Estonia is based on the Estonian language and culture. It is a group-specific right of ethnic Estonians, the function of which is the preservation and development of the Estonian language cultural space as a whole. The argument behind establishing this goal in the programme holds that Estonia is the only place in the world where it is possible to preserve the Estonian culture as a whole. The exclusion of this goal from the integration strategy would have failed to address Estonians' core threat perception and, in turn, would have resulted in the loss of Estonian support for the strategy.

The integration model presumes that multicultural society should be based on sufficient common ground in the public sphere, which would promote common interests and mutual interaction between individuals, as well as the majority and minority groups. The concept of a strong common ground in the public sphere in the Estonian integration model is inspired by the attempts within substantive liberalism to combine conflicting principles of individual and collective rights. On the one hand, the common public sphere entails basic individual rights and democratic institutions. In this respect, integration constitutes a relationship between the state and the individual, in which individuals integrate around the values and institutions of the common public sphere. On the other hand, the public sphere also denotes the idea of a common societal culture, based on knowledge of the Estonian language.

Finally, translation of the conceptual model of integration into concrete integration measures presumes defining the proportions of unity and difference in concrete integration domains as well. In the integration programme, three broad domains, as well as respective policies are defined as follows: first, the integration policy in the language and communication domain, which aims to reproduce a common information space, as well as an Estonian language public sphere, in the context of cultural diversity and tolerance between the groups. Second, the integration policy in the legal-political domain, directed at common values, as well as reducing the number of stateless people in Estonia. Third, the integration policy in the socio-economic domain, which aims to ensure equal labour market possibilities for all members of the society, regardless of their nationality (MPEA 2000). The integration programme describes detailed integration measures in relation to these three domains, the target groups, the institutions responsible, the budget and the management plan.

As this section concludes, it is worth providing a brief description of the new integration strategy adopted by the Estonian government in April 2008. The concept of this strategy is based on the previous programme. The document defines integration as a friendly and safe 
coexistence, which is based on mutual acceptance and respect between both language communities. Integration presumes that all residents of Estonia have an equal interest, desire and opportunity to contribute to the development of the nation and to participate in social life, regardless of ethnic background and mother tongue. The strategy also stipulates that integration is a long-term process aimed at increasing the feeling of social belonging among all residents, based on the common values of the Estonian society and competence in the state language. The strategy aims at achieving conditions where all permanent residents of Estonia, irrespective of their ethnic origin, feel secure in Estonia, are competent in the state language, share the values underlying the Estonian Constitution, and are able to lead a fulfilling life by participating in the societal, economic and cultural life of the country (MPEA 2008).

\subsection{Conclusion}

The central issues of integration policy in Estonia are the existence of parallel societies originating from the Soviet period, emerging socioeconomic and political disparities between ethnic groups and the need to overcome the mutual threat perceptions of the two language communities. These issues are elaborated both in the official integration documents and in the theoretical discussions grounding them. However, the chapters in this volume, as well as the regular integration monitorings, indicate that the results of the integration processes so far are rather modest at best.

There are both historical and contemporary reasons behind such a state of affairs. Progress in national integration depends on not only the targeted integration policies that the ministries and the Integration Foundation are responsible for, but also on the way the entire political and governmental system approaches generic integration issues. Regarding the latter, there are a number of factors that still reproduce separation and disparity between the Estonian majority and Russian minority. In particular, the high proportion of people with undetermined or Russian citizenship does so. The inability of the Estonian political elite to bring the nation-state model chosen at the beginning of the I990s into accordance with the needs of the present day challenges in Estonia is an important factor limiting further progress of national integration. The current nation-state model was adopted in a specific socio-political context of transition from Soviet rule to an independent Estonia and it fulfilled specific goals related to that context and that period. Now, both Estonia's internal and international conditions have fundamentally changed, not least because Estonia is now a member of the 
EU and NATO. One could suppose that such a change would have an impact on handling the problematic issues of generic integration. However, both external and internal factors have prevented this from happening. In particular, regular confrontations between Estonia and Russia, and the fact that this has become an essential element in the domestic politics, are politicising the integration issue and, as a result, continuing ethnic segmentation, disparity and reactivity in Estonian society.

\section{Notes}

I In May 2009, following the dismantling of the governmental coalition, the institution of Minister of Population Affairs ceased to exist, while the Ministry of Culture took over the role of coordinator of integration policies in Estonia.

2 The author of this chapter found himself in a fortunate and, in a sense, exceptional situation. In spring I999, while elaborating on theoretical ideas for a project on the theoretical foundations of multiculturalism at Ahland Peace Institute, he was invited to participate in the commission of experts set up by the Estonian government in order to draft the integration programme. As a result, the discussion in this chapter of the conceptual premises of the integration programme is based on first-hand experience.

\section{References}

Birckenbach, H.-M. (I998), 'From dividing conflict to integration', paper presented at the ECMI Baltic Seminar Minorities and Majorities in Estonia: Problems of Integration at the Threshold of the EU. Flensburg, Germany and Aabenraa, Denmark, 22-25 May 1998.

Brosig, M. (2008), 'A plan for the future? The Estonian state integration programme on national minorities 2000-2007', in Journal on Ethnopolitics and Migration Issues in Europe 7 (2): I-I9.

Castells, M. (I997), The information age: Economy, society and culture, vol. II: The power of identity. Oxford: Blackwell.

Connor, W. (I972), 'Nation-building or nation-destroying?', World Politics 24 (3): 3I9-355.

Constitution of the Republic of Estonia, 29 June 1992, www.unhcr.org/refworld/docid/ 3ae6b56a4.html. Accessed I5 January 2009.

Deutsch, K. (I963), Nationbuilding. Silicon Valley: Atherton Press.

Ehala, M. (forthcoming), 'Etnogenees Eestis', Acta Politica (The Publication of Tallinn University Institute of Governance and Politics) 3: 65-87.

Feldman, G. (2003a), 'Stabilizing Estonia: The international dimension of state security and ethnic integration policy', Demokratizatsiya II (4): 555-57I.

Feldman, G. (2003b), 'The European-ness of Estonia's ethnic integration policy: Nation, culture, and security in an applicant state', Cambridge Review of International Affairs I6 (2): $223-238$.

Feldman, G. (2005a), 'Culture, state and security in Europe: The case of citizenship and integration policy in Estonia', American Ethnologist 32 (4): 676-694. 
Feldman, G. (2005b), 'Estranged states: Diplomacy and the containment of national minorities in Europe', Anthropological Theory 5 (3): 219-245.

Feldman, G. (2008), 'The trap of abstract space: Recomposing Russian-speaking immigrants in post-Soviet Estonia', Anthropological Quarterly 8I (2): 3II-342.

Gordon, M. (1964), Assimilation in American life. Oxford: Oxford University Press.

Heidmets, M. \& M. Lauristin (1998), 'Sissejuhatus: mitmekultuurilise Eesti valikud', in Mitmekultuuriline Eesti: Väljakutse haridusele. Tartu: Tartu Ülikooli kirjastus.

Hiio, T. (2007), 'Vene ja lääne vahel: Eesti ajaloo tõlgendusi ja rakendusi tänapäeval (Between Russia and the West: Contemporary interpretations and applications of Estonian history)', Vikerkaar I-2: I42-I52.

Kuzio, T. (2002), 'History, memory and nation building in the post-Soviet colonial space', Nationalities Papers 30 (2): 24I-264.

Kymlicka, W. (I995), Multicultural citizenship: A liberal theory of minority rights. Oxford: Clarendon Press.

Kymlicka, W. (2000), 'Estonia's integration policies in a comparative perspective', in A. Laius, I. Proos \& I. Pettai (eds.), Estonia's integration landscape: From apathy to harmony: Interviews with Estonian leaders of public opinion, 29-57. Tallinn: Avatud Eesti Fond and Jaan Tõnisson Instituut.

Laitin, D.D. (2003), 'Three models of integration and the Estonian/Russian reality', Journal of Baltic Studies 34 (2): 197-222.

Lake, D.A. \& D. Rothchild (eds.) (1998), The international spread of ethnic conflict: Fear, diffusion, and escalation. Princeton: Princeton University Press.

Lauristin, M. \& M. Heidmets (eds.) (2002), 'Introduction: the Russian minority in Estonia as a theoretical and political issue', in The challenge of the Russian minority, 19-30. Tartu: Tartu University Press.

Leping, O.-K. \& O. Toomet (2008), 'Emerging ethnic wage gap: Estonia during political and economic transition', Journal of Comparative Economics 36: 599-6rig.

Linz, J. \& A. Stepan (1996), 'When democracy and the nation-state are conflicting logics: Estonia and Latvia', in J. Linz \& A. Stepan (eds.), Problems of democratic transition and consolidation: Southern Europe, South America, and post-communist Europe, 40I-433. Baltimore: The Johns Hopkins University Press.

MPEA (Ministery for Population and Ethnic Affairs) (1999), Integration of non-Estonians into Estonian society: Government action plan. Tallinn: Government of Estonia.

MPEA (Ministry for Population and Ethnic Affairs) (2000), State programme integration in Estonian society 2000-2007'. Tallinn: Government of Estonia.

MPEA (Ministry for Population and Ethnic Affairs) (2008), Estonian integration strategy 2008-2013. Tallinn: Government of Estonia.

Nimmerfeldt, G. (2008), 'Kodakondsus (Citizenship)', in Integratsiooni Monitooring 2008. Aruanne. (Integration of Estonian Society, Monitoring 2008. Report). Tallinn: www. rahvastikuminister.ee/?id=I2051. Accessed I5 January 2009.

Pettai, V. \& K. Hallik (2002), 'Understanding process of ethnic 'control': segmentation, dependency and co-optation in post-communist Estonia', Nations and Nationalism 8 (4): 505-529.

Rex, J. (I996), Ethnic minorities in the modern nation state: Working papers in the theory of multiculturalism and political integration. New York: MacMillan Press.

Saar, E. (2008), 'Haridus (Education)', in Integratsiooni monitooring 2008. Aruanne (Integration of Estonian Society, Monitoring 2008. Report). Tallinn: www.rahvastikuminister.ee/?id=I205I. Accessed I5 January 2009 .

Smith, Anthony D. I99I, National Identity. London: Penguin.

Tamm, M. (2008), 'History as cultural memory: Mnemohistory and the construction of the Estonian nation', Journal of Baltic Studies 39 (4): 499-516. 
Taylor, C. (I994), 'The politics of recognition', in A. Gutman (ed.), Multiculturalism, 25-74. Princeton: Princeton University Press.

Vetik, R. (I999), 'Global human development: Modernization versus postmodernization', Estonian human development report 1999. Tallinn: UNDP.

Vetik, R. (2000), 'Multicultural Estonia: What do we want?' in A. Laius, I. Proos \& I. Pettai (eds.), Estonia's integration landscape: From apathy to harmony: Interviews with Estonian leaders of public opinion, 67-70. Tallinn: Avatud Eesti Fond and Jaan Tõnissoni Instituut.

Vetik, R. (200I), Democratic multiculturalism: A new model of national integration. Mariehamn: Aland Peace Institute.

Vetik, Raivo, 2007. 'Suur ühiskond (Great society)', in R. Vetik (ed.), Kahe vabaduse piiril (On the border of two freedoms), 73-90. Tallinn: K Print.

Vetik, R. (2009), 'The cognitive mechanisms of reproducing confrontation'. Manuscript submitted for publication.

Vihalemm, P. (2008), 'Informeeritus ja meediakasutus (Being informed and the use of media)', in Integratsiooni monitooring 2008. Aruanne (Integration of Estonian Society, Monitoring 2008. Report). Tallinn: www.rahvastikuminister.ee/?id=I2051. Accessed I5 January 2009. 



\title{
4 Ethnic inequalities in education
}

\author{
Kristina Lindemann and Ellu Saar
}

\subsection{Introduction}

One of the most basic questions of integration research is whether the life circumstances of immigrants and natives have converged or diverged. Educational attainment is of key importance for the integration of immigrants and their descendants because education substantially shapes immigrants' labour market outcomes. Ethnic educational inequality is a widespread phenomenon, characterising numerous school systems throughout the world (see Heath \& Brinbaum 2007).

The substantial disadvantage of the first generation of immigrants is explained by the lack of fluency in the language of the host country, foreign educational credentials and foreign work experience. The main conclusion has been that their disadvantages in the labour market may not necessarily be indicative of discrimination but rather, may reflect their lack of resources (Heath \& Cheung 2007). In most Western European countries, the second generation is less disadvantaged. They have grown up and attained education in the country of destination; they are more fluent in the destination language and have broader social networks (Crul \& Vermeulen 2003; Heath \& Cheung 2007). That said, while members of the second generation attain better results than those of the first generation, children of immigrants still experience considerable disadvantages.

The educational outcomes of the second generation provide a challenge for explanations of educational inequalities in the western academic literature (see Ogbu 1997; Kao \& Thompson 2003; Modood 2004; Portes \& Hao 2004; Heath \& Brinbaum 2007). The disadvantages of the second generation in education in Western European and other immigrant countries have been explained by different mechanisms. For various countries, it has been found that ethnic disparities in education are largely the result of differences in the educational and social background of parents (Kao \& Thompson 2003; Kristen \& Granato 2007; Phalet, Deboosere \& Bastiaenssen 2007). Lower educational attainment may result, primarily, from class origin rather than from genuine ethnic traits (Kalter, Granato \& Kristen 2007). Disadvantaged social class origins and low education in the parents' generation lead to 
poorer educational attainment in the second generation (Alba, Handl \& Müller I994; Heath \& McMahon 2005; Hout 2005). Therefore, there is intergenerational continuity in patterns of gross disadvantage. The sociology of education tends to use either structural or cultural factors to explain the effect of social origin on educational attainment. The structural explanations focus on differences in the distribution of resources (primarily, material resources), while cultural explanations focus on parental support and their skills in helping children with their schoolwork, as well as knowledge about how to navigate the educational system.

These explanations emanate from the assumption that the first generation of classic labour migrants was negatively selected in terms of human capital. This is the case in most European as well as other immigration countries, e.g. the United States, Canada or Australia. In much of Western Europe, guest worker programmes were introduced in the I950s and I960s. This led to the establishment of large, relatively low-educated and poorly qualified migrant communities. The question is to what extent these commonly used explanations account for ethnic educational inequalities in Estonia. The patterns of immigration to Estonia differed from classic labour migration in many other Western countries. In the I960s, immigration was promoted and controlled via organised labour recruitment. The first flow of Russian language immigrants served to shape a party and state elite dedicated to imperialist policies and to establish a loyal bureaucracy in Estonia. Among the muchneeded workforce, Estonia received numerous bureaucrats and highranking officials who were essential for overseeing the implementation of Soviet policies, both in the state administration and state enterprises (Kulu 200I). Many Russians, who migrated to Estonia at this time, did so right after attaining a vocational or higher education. In other words, they had a high level of education. In the early i980s, however, the educational level of arriving immigrants deteriorated substantially. The majority of those arriving were young people without any vocational training (see Saar \& Titma I992).

In the Soviet period, parallel educational systems, which divided the schools based on the language of instruction (Russian or Estonian), contributed to the segmentation of Estonian society. Then, it was possible to attain all levels of education in Russian. Now, right through to higher education, there are schools with Estonian or Russian language of instruction (hereafter we use the term 'Russian language schools' for schools with instruction given in Russian). Consequently, Russian language secondary schools have become, essentially, educational dead ends. From 2007, all upper secondary schools that previously used Russian as the language of instruction have become bilingual, with the partial teaching of subjects in Estonian. This complexity poses very different kinds of challenges in Estonia compared with most other 
European countries. It means also that many explanations for ethnic stratification formulated for Western European societies are not relevant for the situation in Estonia.

In this chapter, we will take a closer look at ethnic stratification in the Estonian school system, focusing on the track chosen in secondary education and the attainment of higher education. We investigate whether the educational transitions of the second generation relate to differences in educational and social origin. Additional questions raised in this chapter include, does the effect of social background vary between different ethnic groups? Does the Estonian language competence and Estonian citizenship of the parental generation influence educational transitions of the second generation? We are also interested in whether there are tendencies of convergence or divergence between the educational attainments of ethnic groups over time. In order to give an overview of the changes over generations, we compare the educational attainment of Estonians and Russians with the educational level of their parents.

\subsection{The Estonian context}

\subsubsection{Overview of the Estonian educational system}

Pre-school education is not compulsory in Estonia, however, a large percentage of children are enrolled in pre-school institutions. In 2007, 86 per cent of children aged three to six attended kindergarten (Statistical Office of Estonia 2008). Compulsory education starts at age seven, when children must start their studies in basic school. School attendance is compulsory until age seventeen, or until graduation from basic school, if it is achieved before the age of seventeen. In the Estonian educational system, primary and lower secondary education are not differentiated and they form a single level of basic education with nine grades (Figure 4.I). Youth who have not completed basic education can attend vocational training where they also acquire basic education. Basic and secondary schools are mainly public schools, which are tuition free. After basic school, the educational system divides into three tracks: general secondary education, vocational secondary education and vocational education ${ }^{\mathrm{I}}$. The secondary education system in Estonia is quite stratified because it allows little mobility between programmes. The proportion of students continuing in general secondary education grew from 56 per cent in I99I to 72 per cent in 2004 (Saar \& Lindemann 2008).

According to the Education Law, everyone who has a diploma from an upper secondary school, a specialised secondary school or a vocational secondary school, has the right to compete for admission to the universities and institutions of professional higher education. Although 
Figure 4.1 The Estonian educational system

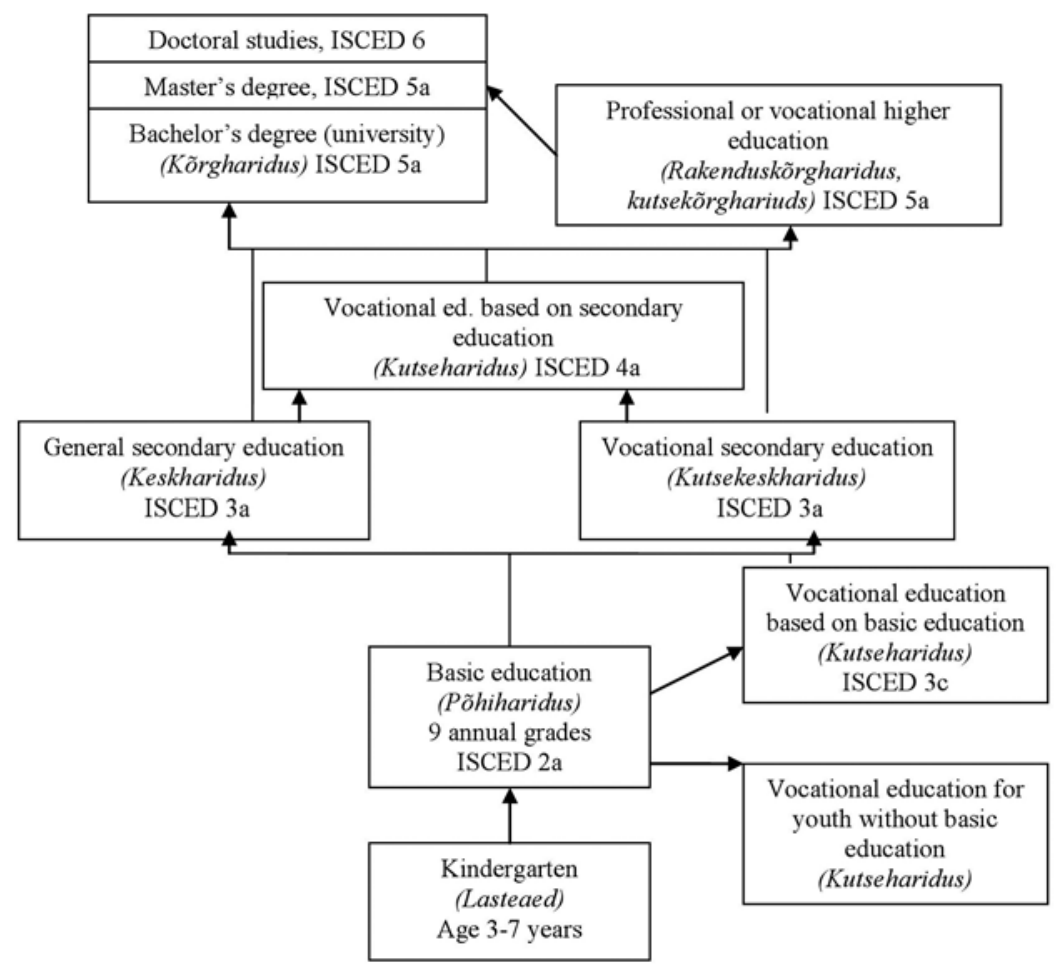

Source: Composed by authors

there are no legal restrictions for graduates of vocational secondary schools to apply to higher education institutions, vocational schools remain educational dead ends: their graduates have very low chances of attaining higher tertiary education and their unemployment rate is higher than that of general secondary schools graduates. National examination grades at graduation from secondary education fluctuate from an average of 40.2 for vocational school graduates to 62.I for graduates of general secondary schools (Estonian Centre for Examination and Qualification 2006). Since admission to higher education institutions is generally based on the results of national examinations, the opportunities to continue studies are unequally distributed across school tracks.

After Estonia regained its independence, the system of higher education was systematically reformed. Higher education is divided into professional higher education and academic higher education. Enrolment levels in tertiary education grew by r68 per cent between the academic years I994-1995 and 2005-2006, which is among the largest growth 
rates among OECD countries (OECD 2006). The number of tertiary students relative to the population of individuals, in the five-year age group following secondary school leaving, reached 64 per cent in 2003 (OECD 2007). Due to liberal higher education policies, the number of private higher education institutions grew very rapidly (Saar \& Lindemann 2008). In 2005-2006, 20 per cent of students were studying in private universities and institutions of professional higher education. Students in Estonia fall into one of two distinct groups: either they occupy state-commissioned places and pay nothing for their tuition or they do not and pay the full costs of their tuition. The number of students paying tuition fees has increased in the 2000s, and in 2007, more than half of all students studied in non-state commissioned institutions (Ministry of Education and Research 2009).

\subsubsection{Ethnic groups in the Estonian educational system}

Compared with Western European countries, a very important specificity is that in Soviet times, Estonia had two parallel educational systems that divided the population based on the language of instruction (Russian or Estonian). Public and private schools at all levels, from preschool to higher education, provide education in Russian. According to the Ministry of Education and Research, numbers of pupils in basic and general secondary schools being taught in the Russian language continue to decline (from 37 per cent in I991 to 20 per cent in 2006). Figure 4.2 indicates that the share of students studying in a language

Figure 4.2 The changing share of students studying in a language other than Estonian in basic and general secondary schools (only daytime studies) (in \%)

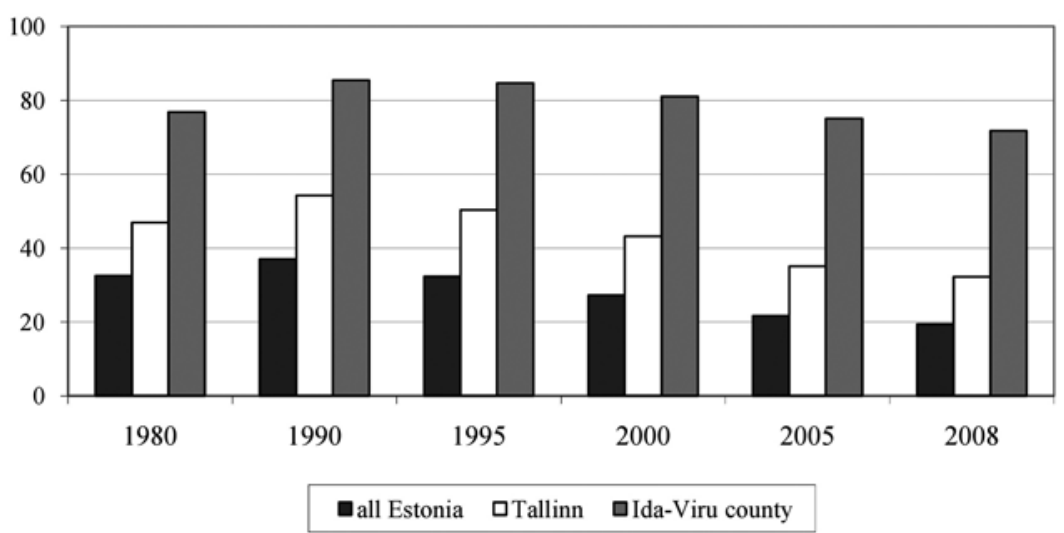

Source: Statistics Estonia 
other than Estonian in general education schools rose somewhat during the I980s because the migration to Estonia was still relatively large. However, the proportion of this type of school has declined rapidly since the beginning of the I990s, particularly in Tallinn where the share of students studying in a language other than Estonian has dropped from 54 per cent to 32 per cent. In the mainly Russian-speaking Ida-Virumaa County, however, the decrease of students studying in Russian has been more modest.

The trends have been somewhat different for vocational schools. From the beginning of the I990s until recent years, there have consistently been about one third of students studying in Russian in vocational schools. However, this proportion has begun to decrease since 2007 following attempts by the Ministry of Education and Research to increase the importance of studies in the Estonian language in vocational schools. In the academic year 2008-2009, only 26 per cent of students studied in Russian in vocational schools (Ministry of Education and Research 2009).

The Estonian government has recognised the need to harmonise the system of general secondary education. In 2007 , educational reform began, with the aim of transforming general secondary schools that used Russian as the language of instruction into bilingual schools, where 60 per cent of all studies will be in Estonian. According to legislation for the 2OII-2OI2 academic year, the national curriculum for those entering Ioth grade will comprise five courses in the Estonian language (Estonian literature, civic education, music, Estonian history and geography). Estonian language instruction in at least Estonian literature started from I September 2007 in the Ioth grades of Russian language schools (Ministry of Education and Research 2009). In 2007, I7 per cent of Russian pupils studied either in ordinary Estonian schools or in language immersion classes (where education is predominantly in Estonian).

During the Soviet Union period, it was possible to attain higher education in both Estonian and Russian and many professions were taught in Russian and Estonian simultaneously. Although there are no clear data available about exactly which professions these were and in what period they were taught, it is likely that this situation contributed to further ethnic segmentation in working life (Helemäe, Saar \& Vöörmann 2000). After Estonia regained its independence, the system of higher education was restructured. In contemporary Estonia, the language of instruction is mainly Estonian in public higher education institutions. Graduates of Russian language schools face no legal obstacles to studying in higher education institutions in Estonian. It is also possible to continue studies in the Russian language in private higher education institutions, where students have to pay tuition fees. As the authors of the OECD report 'Review of Tertiary Education in Estonia' (2007) 
maintain, given that the main higher education institutions do provide instruction mainly in Estonian, Russian school-leavers find themselves at a disadvantage in accessing these schools. In 2007, 55 per cent of Estonian-speaking school-leavers accessed a state-commissioned place in tertiary education, compared to 48 per cent of their Russian peers (Ministry of Education and Research 2009). In 2007, 69 per cent of all students studying in Russian were studying in private higher education institutions ( 6 per cent of students studying in Estonian attended private institutions). In total, II per cent of all students in higher education are studying in Russian (Ministry of Education and Research 2009).

According to the census data from I989, the average education level of Russians residing in Estonia was significantly higher than the average education level of Estonians. The educational structure reflected the general occupational structure of Estonians and Russians. The share of people with primary or basic education was significantly higher among the Estonians. In 2000, the situation has changed. The educational level of Russians is somewhat lower; the differences in the educational level of non-studying youth in Tallinn are particularly large. Among Russians in Tallinn, the proportion of youth with basic education is higher than that of Estonians and the proportion of Russian youth with higher education is lower (see Table 4.I).

There are ethnic differences in the proportion of studying youth (see Table 4.2). In the age groups I5-I9 and 20-24, the percentage of studying youth is much higher for Estonians than for other ethnic groups. More than a quarter of Estonians aged 20-24 are studying in higher education institutions. Among Russians belonging to the same age

Table 4.1 Educational level of different ethnic groups in 1989 and 2000 (in \%)

\begin{tabular}{|c|c|c|c|c|c|c|c|c|}
\hline \multirow[t]{2}{*}{$\begin{array}{l}\text { Level of } \\
\text { education }\end{array}$} & \multicolumn{2}{|c|}{$1989 *$} & \multicolumn{2}{|c|}{$2000 \%$} & \multicolumn{2}{|c|}{$\begin{array}{c}2000 \\
\text { non-studying youth } \\
(15-29) \text { in Estonia }\end{array}$} & \multicolumn{2}{|c|}{$\begin{array}{c}2000 \\
\text { non-studying youth } \\
(15-29) \text { in Tallinn }\end{array}$} \\
\hline & Estonians & $\begin{array}{l}\text { Other } \\
\text { ethnicities }\end{array}$ & Estonians & $\begin{array}{c}\text { Other } \\
\text { ethnicities }\end{array}$ & Estonians & $\begin{array}{c}\text { Other } \\
\text { ethnicities }\end{array}$ & Estonians & $\begin{array}{c}\text { Other } \\
\text { ethnicities }\end{array}$ \\
\hline Primary & 17 & 14 & 4 & 4 & 2 & 1 & 1 & 1 \\
\hline Basic & 17 & 15 & 12 & 13 & 20 & 17 & 10 & 15 \\
\hline Secondary*** & 27 & 28 & 31 & 28 & 32 & 31 & 37 & 33 \\
\hline Vocational & & & 7 & 8 & 13 & 18 & 10 & 15 \\
\hline $\begin{array}{l}\text { Specialised } \\
\text { secondary }\end{array}$ & 21 & 26 & 20 & 26 & 20 & 21 & 22 & 24 \\
\hline Higher & 18 & 17 & 26 & 20 & 12 & 9 & 20 & 11 \\
\hline Total & 100 & 100 & 100 & 100 & 100 & 100 & 100 & 100 \\
\hline
\end{tabular}

*15-64 year olds

$* * 1989$ general secondary and vocational secondary education together

Source: 1989 and 2000 census data 
Table 4.2 Proportion of studying youth according to age group and ethnic group in Tallinn and in Estonia (in \%)

\begin{tabular}{lccc}
\hline & Estonians & Russians & Other ethnicities \\
\hline In Tallinn & & & \\
Age group 15-19 & 90 & 82 & 85 \\
Age group 20-24 & 49 & 30 & 33 \\
In higher education & 41 & 24 & 27 \\
Age group 25-29 & 20 & 7 & 10 \\
In higher education & 19 & 6 & 9 \\
In Estonia & & & \\
Age group 15-19 & 87 & 83 & 84 \\
Age group 20-24 & 36 & 25 & 29 \\
In higher education & 28 & 18 & 10 \\
Age group 25-29 & 13 & 4 & 9 \\
In higher education & 12 & & 22 \\
\hline
\end{tabular}

Source: 2000 census data

group, this percentage is substantially lower. Differences in Tallinn are particularly large. The data indicates that there is unequal access to higher educational institutions between Estonians and Russians.

\subsection{Accounting for ethnic differences in education}

Most explanations of ethnic educational inequality start from various models of educational decisions (Breen \& Goldthorpe 1997; Esser 2004). An individual's educational choices will include considerations of the possible costs and benefits of alternatives in the education system, and of the probabilities of different outcomes, such as educational success or failure. According to these models, the costs, benefits and probabilities should vary between immigrants' descendants and the native population. Therefore, transition rates should differentiate across ethnic groups. In addition, a process of cultural reproduction might affect these transitions in the educational system. The second generation may lack access to the heritage culture of the native population that, according to Pierre Bourdieu, is crucial for educational success.

The finding that the general processes of social reproduction are related to lower educational attainment of the second generation is common. Therefore, most Western European authors start to explain ethnic disadvantages with arguments that focus on the processes by which social and educational origin affect transitions in the educational system (Fekjær 2007; Kristen \& Granato 2007; Kristen, Reimer \& Kogan 2008). A central argument connecting social background with children's educational attainment refers to differences in the distribution of 
resources and characteristics that are relevant to educational decisions. Economic resources in the family are one of the factors influencing perceived costs and benefits (Goldthorpe 2000). Apart from financial conditions, other types of parental support vary by social origin. In addition, there is a group of arguments that concerns class differences in educational aspirations. It is presumed that the higher social classes favour the more demanding and prestigious qualifications (Boudon I974; Gambetta i987).

However, explanations linking social origin with educational choices cannot account for the ethnic educational inequalities in Estonia. As previously mentioned, the first generation in Estonia was not negatively selected in terms of their education and occupational position. Therefore, social disadvantages may not account for ethnic disadvantages in educational transitions in Estonia. On the other hand, as the Russian minority situation in the labour market has been more vulnerable, their returns from education in terms of economic success have been lower (see Leping \& Toomet 2008). It is possible to conclude that the parents of Russians need an even higher educational level than Estonians to produce similar educational opportunities for their children.

In most Western countries, the educational disadvantage for ethnic groups persists even after taking into account parental socio-economic position (Heath \& Brinbaum 2007). Some authors explaining these differences refer to so-called primary effects of stratification. ${ }^{2}$ They argue that the lack of the requisite cultural capital, and particularly a parental lack of fluency in the language of the majority population, may make it difficult for children of some immigrant groups to succeed in their schoolwork. This, in turn, may lead to lower achievement in test scores than would be expected based on their parents' socio-economic position (Van de Werforst \& Van Tubergen 2007). Therefore, it is possible to conclude that parental lack of country-specific human capital and particularly non-fluency in the language of the native population often reduces the achievement of children (Heath \& Brinbaum 2007). However, because there are separate Estonian and Russian basic and secondary schools, and almost no differences in achievements in these schools, it is questionable just how much this explanation accounts for ethnic educational inequalities in Estonia. In 2007, there were no considerable differences between pupils studying in Estonian and Russian with regards to average points received on state exams (final exams at secondary education graduation), with the exception of geography, foreign languages and social sciences exams (where the results of Estonian language schools graduates were noticeably higher) (Estonia State Centre for Exams and Qualification 2008). Furthermore, there were 
few differences between ethnic groups with regard to the practical involvement of parents in studies (Lindemann 2008).

There might also be secondary effects of stratification on educational choices. Immigrant parents lack familiarity with the education system and are less informed about the outcomes of possible educational choices. This lack of knowledge about the functioning of the school system also leads to less-informed educational choices. This reasoning applies, in particular, to the first generation, but it also affects the education of the second generation who, especially at younger ages, rely heavily on their parents' knowledge and school support (Kristen \& Granato 2007). It also makes investment in education unlikely, as the parents' low level of information strongly reduces success expectations (Esser 2004). Heath and Brinbaum (2007) use the term 'cultural dissonance' when referring to this potential explanation. However, the existence of two parallel educational systems with Estonian and Russian as the languages of instruction makes this reasoning questionable in Estonia, especially for transition to general secondary education.

The second group of arguments concern ethnic differences in educational aspirations (Kao \& Thompson 2003). However, some authors indicate that rather than referring to ethnic disadvantages, aspirations may account for a group's more ambitious choices and exceptional educational success (Kao \& Tienda I998; Kao 2004; Brinbaum \& CebollaBoado 2007; Kristen et al. 2008). In order to explain this difference, some authors point to positive cultural values and beliefs about the benefits of education (Caplan, Choy \& Whitmore I991). Other authors refer to positive selection of immigrants in terms of their motivation to succeed (Kao \& Tienda I995). Additionally, Stanley Sue and Sumie Okazaki (I990) state that education is functional for upward mobility, particularly when participation in other avenues for advancement has been difficult. Results of the survey Integration of Estonian Society: Monitoring 2008 seem to indicate that, in Estonia, the Russian population is slightly more oriented towards tertiary education compared to Estonians (not taking into account their socio-economic position) (Saar 2008). Thus, there is no reason to expect that ethnic inequalities in education can be explained by ethnic differences in the educational aspirations.

The secondary effect concerns not only aspirations but also real choices made in branching points comprising the educational system. Raymond Boudon (I974) sees the choices as being determined via the evaluation that children and their parents make of the costs and benefits of different tracks, and the chances of success within them. However, even among children who reach the same levels of achievement and have similar aspirations, the secondary effect will still produce ethnic differences in attainment. Thus, children who reach the same levels of achievement and have similar aspirations may still make 
different educational choices. Educational decision-making remains conditioned by the situation in which it takes place, and this is likely to lead to differing evaluations of costs and benefits, as well as the chances of success (Goldthorpe 2000: 174). The national institutions, e.g. the educational systems, play a central role in this evaluation process. We posit that the rational basis of educational choices, determined by institutional conditions, might be the main mechanism producing ethnic educational inequalities in Estonia.

An additional mechanism, human capital externalities, is also used to explain inequality between ethnic groups (Borjas i995). Thus, the representatives of the second generation may be affected not only by parental education and occupational group, but also by the average education of the ethnic group in the parents' generation. The ethnic externality might operate through the ethnic neighbourhood, which will tend to reduce the educational attainment of the second generation (for example, through a process of lowering expectations). In Estonia, there is a clear territorial ethnic segregation, as well as a segregation of schools according to the language of instruction (ethnicity). Nevertheless, we are suspicious of the claim that the ethnic composition of schools is an indicator of the different learning opportunities children confront in different classrooms in Estonia. In Estonia, Russians are not concentrated in neighbourhoods predominantly composed of low-income families, which will reduce their educational attainment because of the poorer quality of schooling. There is no reason to believe that the ethnic composition of the school may have an impact on children's educational performance. In addition, the educational level of the parental generation of Russians is even higher compared with Estonians (see Table 4.I).

Finally, institutional conditions have an influence on the second generation's educational attainment as well. While some institutional regulations may apply only to the children of immigrants, those institutional rules that apply to all the children may have a different impact on ethnic groups. We suppose that this group of arguments is more able to account for educational differences between ethnic groups in Estonia. The fact that the main higher education institutions provide instruction mainly in Estonian remains an important obstacle to overcome in order to achieve ethnic educational equality. It can limit the educational opportunities of people who lack proficiency in Estonian. School reform supports the idea that Russian students must acquire a good command of the Estonian language at school. The reality looks different. According to data from the survey Integration of Estonian Society: Monitoring 2008, only 27 per cent of Russian respondents aged I5-29 estimated their knowledge of Estonian as being fluent; and nearly a quarter have poor Estonian language proficiency. Furthermore, there 
was a negative assessment of the quality of teaching of Estonian in schools: more than a third of Russian respondents thought that they (or their children) do not learn enough Estonian at school (Saar 2008).

The continuation of studies in private higher education institutions, where students pay tuition fees, is costly. Insufficient proficiency in Estonian generally means that continuing studies is possible only if the individual has enough economic resources. Access to economic resources is often related to parental background. As inflow into higher education institutions is mostly from general secondary schools, lower success expectations for transition to higher education may also affect the choice of the secondary school track of Russian youth, decreasing their probability of continuing their studies at general secondary schools. They may rationalise a preference to enter vocational secondary education rather than continue their studies in general secondary education.

The second question is whether social background has the same effect for both ethnic groups. There have been expectations that restricted transferability of origin-specific educational resources may affect the ability of immigrant families to make educational investments (Heath \& Cheung 2007). Social background may matter less for the second generation, because their parents' social standing declined after migration. Education of the children may give the family an opportunity to reclaim what the parents lost through migration (Platt 2005). However, some authors indicate the possibility that social background could have a stronger effect on educational attainment among minority youth, because some minority parents will experience discrimination and language problems in a new society (Fekjær 2007). This implies that the first generation has had to work harder to achieve their position in society than their counterparts in the majority group. Those who have managed to achieve a high position might have extra resources (for example, social networks). This suggests that those minority youth whose parents have higher levels of education and status have the advantage.

Educational expansion may also increase the impact of social background on educational attainment among the second generation. Frank Kalter and Nadia Granato (2002) found that educational expansion has led to an overall increase of educational inequalities between ethnic groups. There are some similarities with the concept of 'maximally maintained inequality' in education (Raftery \& Hout I990). These authors argue that class differences in educational attainment will only begin to decline when the participation of children from more advantaged backgrounds in a given level of education reaches saturation. We posit that the same assumption is also true for different ethnic groups, increasing the impact of social background on the educational attainment of the minority ethnic group. 
More precisely, we derive the following hypotheses from our theoretical discussion:

Hypothesis 1. Looking at the historical case of migration to Estonia, we expect no ethnic differences in educational attainment of the parental generation.

Hypothesis 2. Due to the transformation of Estonian society and the growing importance of country-specific human capital, we expect that educational inequality has substantially increased for the second generation.

Hypothesis 3. We expect to find significant gross and net effects of ethnicity on transition to general secondary schools, as well as to higher education institutions.

Hypothesis 4. We suppose that parents' education and occupational group have a stronger impact on the educational choices of Russian youth.

Hypothesis 5. We suppose that parental country-specific human capital has no impact on the educational transitions of the second generation.

\subsection{Variables and method}

We are using a dissimilarity index to compare the educational composition of the parental generation and the second generation and to indicate trends of convergence or divergence. This measure attempts to capture the degree of social inequality in one single variable. The index of dissimilarity is defined as:

$\mathrm{D}=\frac{1}{2} \sum\left|\mathrm{A}_{\mathrm{k}} / \mathrm{A}-\mathrm{B}_{\mathrm{k}} / \mathrm{B}\right|$,

where $\mathrm{A}$ is the number of people belonging to group $\mathrm{A}, \mathrm{B}$ is the number of people belonging to group $B, A_{k}$ is the number of persons belonging to group $A$ and category $k$, and $B_{k}$ is the number of persons belonging to group $\mathrm{B}$ and category $\mathrm{k}$.

In order to investigate the transition patterns in the education system, we must first examine the sub-sample of young people with at least secondary education and investigate whether they choose for general secondary education rather than the vocational track. Second, we analyse whether students enter higher educational institutions and successfully complete this education or not. This latter category comprises individuals who take up vocational training or decide not to pursue further education or enter to higher education, but do not complete their studies.

We use a social class schema that takes into account the social class of both parents. Our primary measure of social class is based on the occupational group of the mother and father when the respondent was fifteen years old. When one parent is absent from the household, or when 
data on one parent is missing, the single parent, or the parent for whom data is available, determines the class origin of the child. In line with the dominance approach, the educational attainment of the child does not differ significantly once the class of the parent whose occupational group was higher is taken into account (see Phalet et al. 2007). We are using a fourfold class schema:

- manager and professional: at least one parent in a professional or managerial occupation

- lower non-manual worker: at least one parent in a routine non-manual occupation; the other parent in similar occupation or in skilled or unskilled manual work, or not working

- skilled manual worker: at least one parent in skilled manual work; the other parent in similar manual work, or in unskilled manual work, or not working

- unskilled manual worker: at least one parent in unskilled manual work; the other parent in similar manual work, or not working.

In addition, the highest educational qualifications of the parents are also measured. Our measurements derive four categories:

- at least one parent with higher education

- at least one parent with vocational or professional secondary education; the other parent has similar or lower qualifications

- at least one parent with general secondary education; the other parent with similar or lower qualifications

- both parents, or a single parent, with primary or basic education.

This analysis does not take into account the respondent's Estonian language proficiency. Our data about educational transitions is retrospective, but we measure language skill at the time of the interview. Therefore, it is not possible to give an adequate estimation of its influence on transitions in the educational system.

Estonian language proficiency and Estonian citizenship serve as a proxy of parental country-specific human capital. We are using the following categories for Estonian language proficiency:

- very good

- good

- moderate

- very bad.

We have also included the data about the Estonian citizenship of both parents into our analysis:

- both parents hold Estonian citizenship

- one parent has Estonian citizenship

- neither parent has Estonian citizenship. 
Regarding the transition to higher education, we consider the additional variable of secondary school track.

In considering ethnic minority disadvantage in the educational system it is important to distinguish between three distinct concepts (see Heath \& Cheung 2007):

- gross disadvantage

- net disadvantage after checking for social background and other individual characteristics

- differential impact of social background.

We use logistic regression analysis including variables to model, step by step, the separate gross and net disadvantages. In a most simple baseline model, ethnicity is entered as a predictor of transitions in the educational system. In the subsequent models, we test the role of various kinds of parental resources as explanatory variables.

\subsection{Results}

\subsubsection{Educational attainment of parents and second generation}

Table 4.3 gives an overview of the educational composition of the parental and second generations. We use an index of dissimilarity to describe the extent of differences between ethnic groups. It appears that differences in educational attainment of the two ethnic groups are larger for second generation than they were for their parents. In particular, dissimilarity has increased for women. In the generation of mothers, there are only small differences in educational attainment between ethnic groups. The educational level of Russians is even slightly higher: Russians more often have mothers who have completed higher education, while more Estonians have mothers who have finished only basic school or less. On the other hand, the dissimilarity of women's educational attainment between second generation Russians and young Estonians is much higher with the advantage going to the Estonians. It appears that Estonian women tend to attain higher education more often, while Russian women more frequently complete professional or vocational secondary school.

The index of dissimilarity of educational attainment is also higher for men. In the generation of fathers, Estonians more often tend to have basic education or less, while Russians more often have higher education. Results indicate that among Russian men, educational attainment has changed extensively over the course of a generation. In the case of the second generation, fewer Russian men have attained higher education compared to Estonian men. Russian men, like Russian women, more often attained vocational or professional secondary education, 
Table 4.3 Educational composition of parental and second generation (in \%)

\begin{tabular}{|c|c|c|c|c|c|c|c|c|}
\hline & \multicolumn{2}{|c|}{ Father } & \multicolumn{2}{|c|}{ Men } & \multicolumn{2}{|c|}{ Mother } & \multicolumn{2}{|c|}{ Women } \\
\hline & Estonians & Russians & Estonians & Russians & Estonians & Russians & Estonians & Russians \\
\hline $\begin{array}{l}\text { Primary } \\
\text { and basic }\end{array}$ & 14.7 & 7.1 & 16.2 & 13.3 & 9.2 & 5.2 & 10.9 & 13.8 \\
\hline $\begin{array}{l}\text { Vocational } \\
\text { and } \\
\text { professional } \\
\text { secondary }\end{array}$ & 42.4 & 44.7 & 39.6 & 56.2 & 42.6 & 43.4 & 33.6 & 47.7 \\
\hline $\begin{array}{l}\text { General } \\
\text { secondary }\end{array}$ & 22.7 & 23.3 & 23.4 & 18.1 & 23.1 & 23.6 & 20.0 & 15.9 \\
\hline Higher & 20.2 & 24.9 & 20.7 & 12.4 & 25.1 & 27.8 & 35.5 & 22.6 \\
\hline Total & 100 & 100 & 100 & 100 & 100 & 100 & 100 & 100 \\
\hline $\begin{array}{l}\text { Index of } \\
\text { dissimilarity }\end{array}$ & \multicolumn{2}{|c|}{.073} & \multicolumn{2}{|c|}{.161} & \multicolumn{2}{|c|}{.038} & \multicolumn{2}{|c|}{.170} \\
\hline
\end{tabular}

Source: Own calculations based on TIES

while Estonian men more frequently complete general secondary school. These results concur with data from the censuses presented in Table 4.I. Thus, contrary to most Western European countries, the educational gap between second-generation Russians and young Estonians has grown compared to their parents' generation (to first-generation immigrants and Estonians).

\subsubsection{The influence of parental resources on transitions in the educational system}

As the educational attainment of second-generation Russians and young Estonians is rather different, it is necessary to examine how the ethnicity and social background of parents influence the transitions of the second generation in the education system. We used logistic regression models in order to estimate to what extent the ethnicity or social background of parents has an effect on transitions to secondary and higher education. In the case of choices about secondary education, we examined the odds of transition to general secondary school versus to other types of secondary education (vocational and professional). We also estimated the odds of transition to higher education compared to not continuing studies in higher education after the attainment of secondary education, or continuing in higher education but not finishing studies. We added variables into the analysis step by step, starting with the model for gross effect of ethnicity. Next, we added demographic characteristics such as gender, age and region and finally, variables about parents' social background. Figure 4.3 presents the odds ratios of transition to general secondary school and to higher education, comparing the effect 
of ethnicity in different models and illustrating what happens to the initial ethnic disadvantages when taking into account the relevant background variables. Values below one indicate that the second generation's chances of transition are below those of Estonians. Appendix 4.I shows the model fit.

Figure 4.3 indicates a clear gross effect of ethnicity on transitions in the education system. Compared to Estonians, Russians are less likely to choose studies in general secondary school as opposed to other types of secondary education. In addition, the odds of Russians' transition to higher education are lower than that of Estonians. Taking into account demographic characteristics does not change the strong effect of ethnicity. In the case of the odds of transition to higher education, the effect of ethnicity even increases slightly. This indicates that there are significant differences in transition to higher education between Russians and Estonians, who are characterised by similar age, gender and place of residence.

Adding parental class and education into the model does not reduce the strong effect of ethnicity. Therefore, where Russians and Estonians have parents with a similar educational level and social class, Russians tend to continue their studies less often in general secondary education instead of another type of education. In addition, in the case of similar parental resources, the odds of Russian transition to higher education are lower. Taking account of social background, Russians still encounter disadvantages. Thus, as expected, different social backgrounds do not explain ethnic differences in educational transitions in Estonia. This means that the story of the second generation's lower educational attainment is very different from most Western European countries, where the low performance of the second generation is primarily explained by negative selection in terms of parental education and social position.

In order to specify whether the influence of parental resources on transitions in educational system varies between ethnic groups, we added interactions into the logistic regression model (see Appendix 4.I). To some extent, this improves the model fit in the case of both models, which indicates that the effect of social background on educational choices differs for Estonians and Russians. The models with interaction terms (not presented here, available from authors upon request) show that the impact of social background on transitions in the educational system is stronger for Russians.

It is also important to note that adding the type of secondary education into the model about transition to higher education does not change the strong effect of ethnicity. It shows that even in the case of similar types of secondary education, Russians are still less likely to continue their studies in higher education. 
Figure 4.3a Gross and net ethnic educational disadvantage: Odds of transition to general secondary school (versus other type of secondary education)

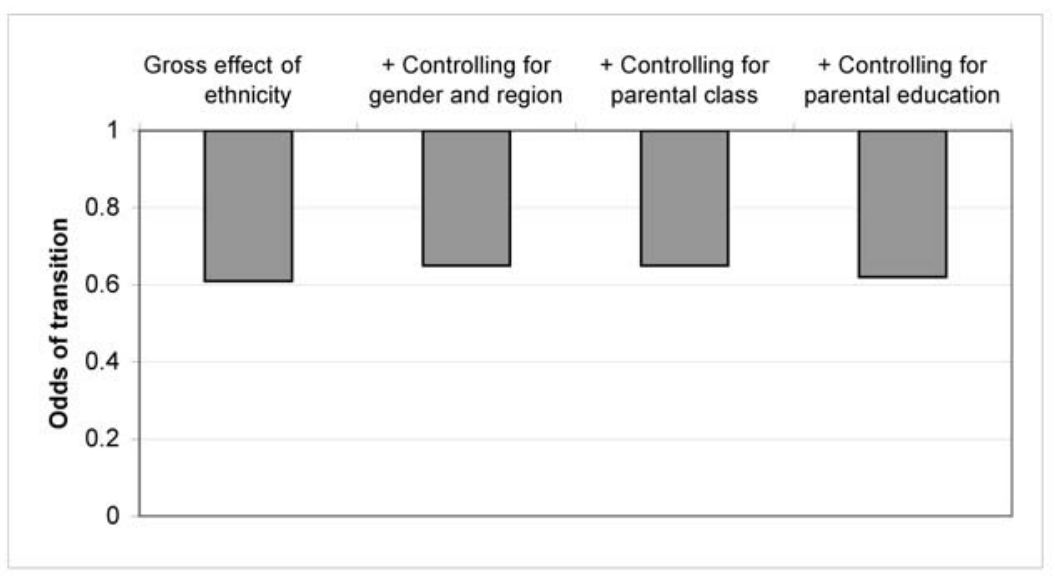

Source: Own calculations based on TIES

Figure 4.3b Gross and net ethnic educational disadvantage: Odds of transition to, and completion of, higher education (versus not continuing studies in higher education after attainment of secondary education or not finishing these studies)

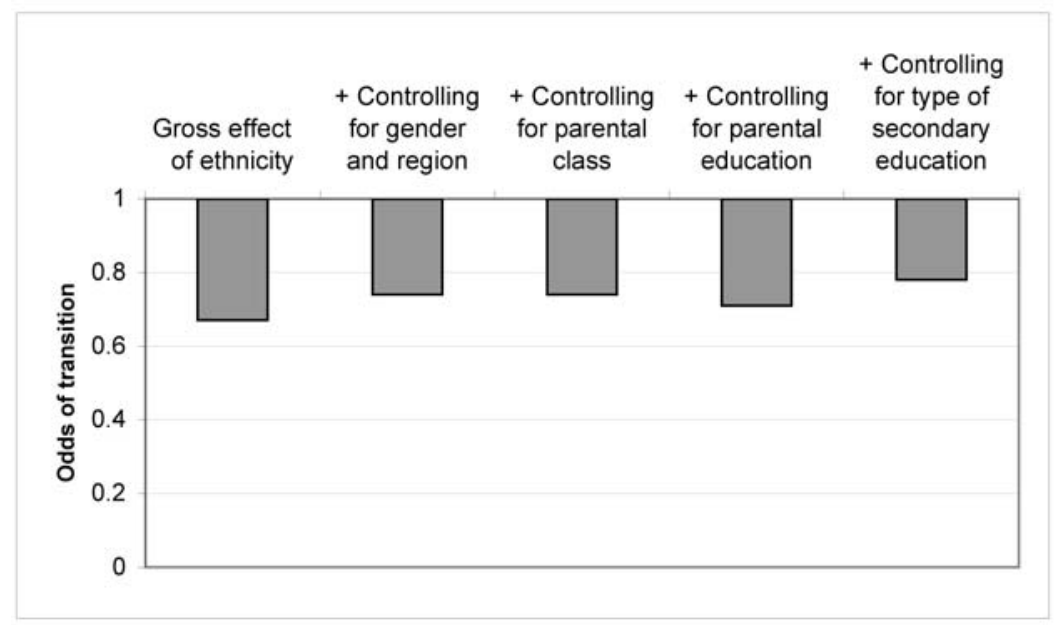

Source: Own calculations based on TIES 
We calculated the probabilities of transition to general secondary education, as well as of transition and finishing studies in higher education, for Estonians and Russians using models with interaction terms. The probability of transition to general secondary school is 0.74 for Estonians and much lower for Russians (0.66). The gap is even bigger for transitions to higher education (0.36 and 0.I9, respectively).

\subsubsection{The role of parental resources in choices of secondary education}

Figure 4.4 specifies the relationship between the probability of continuing studies in general secondary education and social origin. Results show that Estonians and Russians with similar parental education continue studies in general secondary education with different probabilities. The largest difference between ethnic groups appears among youth whose highest parental education is basic education or less. Russian parents with basic education indicate a very low probability of entering general secondary education. However, for Estonians with a similar parental education, the probability of continuing studies in general secondary school is about 0.5. Russians who have parents with general secondary education are less likely to continue their studies in the general track of secondary education when compared to Estonians. The most likely to enter general secondary school are Estonians whose parents have higher education. Young Russians whose parents have higher education continue their studies in general secondary school with the same probability as young Estonians whose parents have vocational or professional education.

The probability of transition to general secondary school also differs among Estonians and Russians whose parental occupational group is similar. Estonians whose parents are managers or professionals are more likely to continue their studies in general secondary school. There is also quite a high probability that Russian youth with a similar parental occupation group enter general secondary school, although this is about o.I lower than Estonians. In the case of youth whose parents are skilled workers, there is almost no difference between ethnic groups. However, those Estonians whose parents belong to the group of unskilled manual workers ${ }^{3}$ are less likely to enter general secondary education when compared to Russians with similar parental education.

The previous figure shows that social origin might have a different influence on the probabilities of ethnic groups entering general secondary education. Therefore, we calculated the effects of social background characteristics on the choice of secondary school separately for Estonians and Russians. Table 4.4 gives an overview of how these characteristics influence the probability of Estonians and Russians continuing their studies in general secondary education, rather than in other 
Figure 4.4 Probabilities of transition to general secondary school by ethnicity and social origin
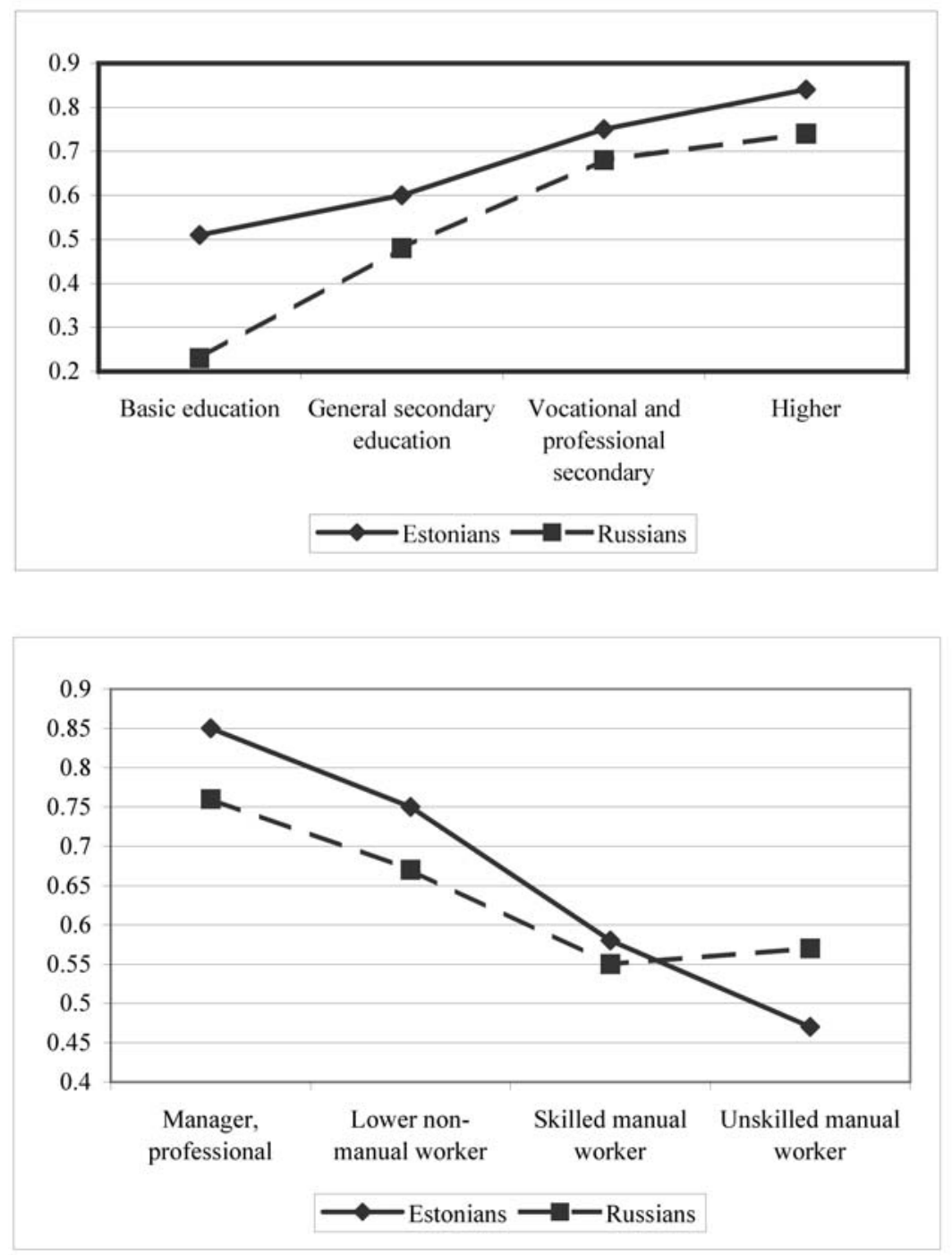

Source: Own calculations based on TIES

types of secondary education. We also carried out an additional model for Russians, where Estonian language skills and parental citizenship were taken into account.

In general, the analysis shows some common trends among ethnic groups. In both ethnic groups, women and youth who live in Tallinn 
Table 4.4 Transition to general secondary education (versus other types of secondary education): Logistic regression models

\begin{tabular}{|c|c|c|c|}
\hline & \multirow{2}{*}{ Estonians } & \multicolumn{2}{|c|}{ Russians } \\
\hline & & Model 1 & Model 2 \\
\hline \multicolumn{4}{|l|}{ Gender } \\
\hline Male & $-89 \times 2$ & $-.66 * 2 * *$ & $-.62 * *$ \\
\hline Female (reference group) & & & \\
\hline \multicolumn{4}{|l|}{ Age group } \\
\hline $18-25$ & -.01 & 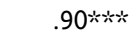 & $.89 * * * *$ \\
\hline \multicolumn{4}{|l|}{$26-35$ (reference group) } \\
\hline \multicolumn{4}{|l|}{ Region } \\
\hline Tallinn & $.53 * *$ & $1.12 \% * \%$ & $1.10 * \cdots *$ \\
\hline \multicolumn{4}{|l|}{ Kohtla-Järve (reference group) } \\
\hline \multicolumn{4}{|l|}{ Parental occupational group } \\
\hline Manager, professional & $1.62 * *$ & .76 & 76 \\
\hline Lower non-manual worker & $1.20 * *$ & .46 & .47 \\
\hline Skilled manual worker & .42 & .06 & .08 \\
\hline \multicolumn{4}{|l|}{$\begin{array}{l}\text { Unskilled manual worker } \\
\text { (reference group) }\end{array}$} \\
\hline \multicolumn{4}{|l|}{ Parental education } \\
\hline Primary, basic & $-.98 *$ & $-2.12 * *$ & $-2.02 * *$ \\
\hline General secondary & -.60 & $-.72 \% *$ & -.59 \\
\hline $\begin{array}{l}\text { Vocational and professional } \\
\text { secondary }\end{array}$ & -.10 & .05 & .16 \\
\hline \multicolumn{4}{|l|}{ Higher (reference group) } \\
\hline \multicolumn{4}{|l|}{ Estonian language skills of parents } \\
\hline Poor skills & & & .15 \\
\hline Rather poor skills & & & .10 \\
\hline Rather good skills & & & -.12 \\
\hline \multicolumn{4}{|l|}{ Good skills (reference group) } \\
\hline \multicolumn{4}{|l|}{ Parental citizenship } \\
\hline $\begin{array}{l}\text { Both parents have Estonian } \\
\text { citizenship }\end{array}$ & & & $.73 * *$ \\
\hline One parent has & & & .41 \\
\hline \multicolumn{4}{|l|}{ Both have not (reference group) } \\
\hline Constant & .26 & -.25 & -.63 \\
\hline Pseudo R square & .16 & .21 & .22 \\
\hline Number of cases & 488 & 426 & 426 \\
\hline
\end{tabular}

*****ffect significant at $p<0.01$

$\approx *$ Effect significant at $p<0.05$

*Effect significant at $p<0.10$

Source: Own calculations based on TIES 
are more likely to continue their studies in general secondary education. Russians aged I8-25 are more likely to choose for general secondary education than those aged 26-35. There are no differences between age groups among Estonians.

Interestingly, parental occupation group has a stronger effect on the odds of Estonians entering general secondary education. There is no significant effect of parental occupation on Russians choice of secondary school. However, parental education has a significant influence on the probability of Russian youth continuing studies in general secondary education. One explanation for this result is low correspondence between occupational group and education for Russians. Previous analysis also indicates that Russians with higher education have considerably more difficulties in finding a higher professional or managerial job (Saar \& Kazjulja 2002). According to data from the Estonian Labour Force Survey, a fifth of Russians think that their educational level is higher than their job requires (Helemäe 2008). Russians whose parents have general secondary education or basic education are less likely to continue with their general secondary education than those Russians whose parents have higher education. In the case of Estonians, only those youth whose highest parental education is basic or less are disadvantaged. The effect of parental education on the Russian situation decreases somewhat after parents' Estonian language skills and citizenship are added into the model. Those Russian youth who have two parents with Estonian citizenship are more likely to continue their studies in general secondary school. Additional analysis indicates that the impact of this indicator is significant only in Kohtla-Järve, where the percentage of Russian youth continuing their education in general secondary schools is substantially lower compared with youth in Tallinn ${ }_{5} 6$ per cent and 78 per cent, respectively). Thus, in the case of Russians who have parents with Estonian citizenship, their chances of entering secondary school are equal to Estonians. However, we found no significant influence of parents' Estonian language skills on the choice of secondary school. It should be noted, though, that we analysed respondents who moved to secondary school in rather different periods. Some respondents belonging to the older age group had already made a decision about the secondary school track at the beginning of 1990, while others made their choice in the zooos. The influence of parental country-specific human capital may vary during these years.

\subsubsection{The influence of social origin on the transition to higher education}

Figure 4.5 shows how the probabilities of transition to higher education differ by ethnic groups and social origin. Russian youth whose highest parental education is basic or general secondary have a very low 
Figure 4.5 Probabilities of transition to and completion of higher education by ethnicity and social origin
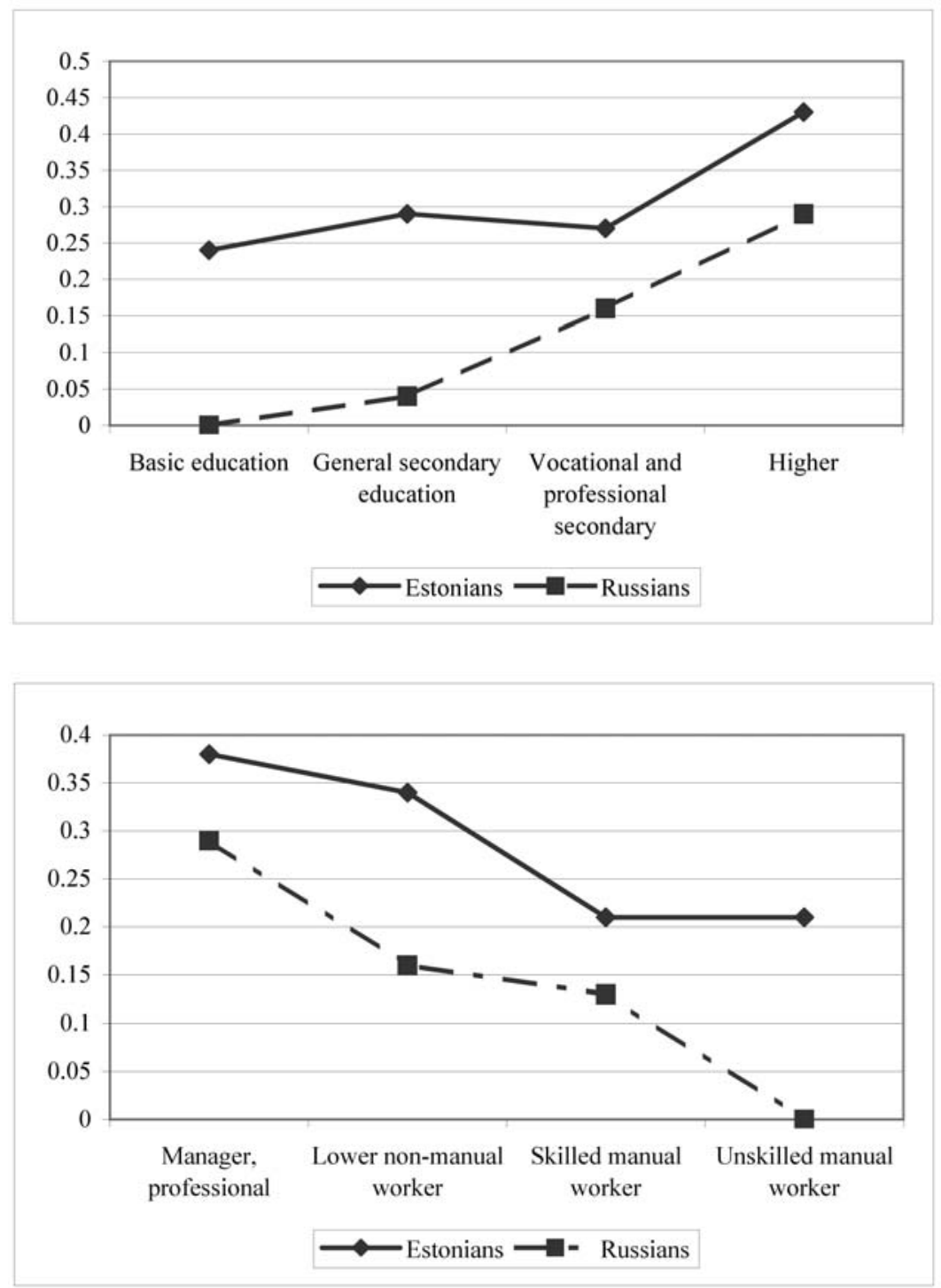

Source: Own calculations based on TIES 
probability of attaining higher education. Russians whose parents are unskilled manual workers also have very low chances of entering higher education. However, Estonians with a similar social background have somewhat higher odds of continuing their studies in higher education. In both ethnic groups, the most advantaged are youth whose parents have higher education or whose parents work as managers or professionals.

Those Estonians whose highest parental occupational group is lower non-manual workers have almost the same probability of continuing their studies successfully in higher education as children of managers and professionals. There is no such tendency in the case of Russians. Young Russians whose parents belong to the group of lower non-manual workers have the same odds of attaining higher education as the children of skilled manual workers. Figure 4.5 indicates that ethnic differences in transition probabilities are larger for youth with a lower social background. Russians need to have parents with higher education and a high occupational position in order to improve their chances of attaining higher education.

The effect of social background on the probability of continuing studies in higher education appears to be, to some extent, different for each ethnic group. Subsequently, we calculate separate logistic regression models for Russians and Estonians (Table 4.5). It appears that younger age groups and men continue their studies in higher education less successfully in both ethnic groups. Region has no significant effect.

Although parental occupational group does not significantly influence youth entry into higher education, the effect of parental education is strong for both ethnic groups. The model for Estonians shows that the most disadvantaged are youth whose parents have only basic education. In addition, Estonians whose parents have vocational or professional secondary education are less likely to attain higher education compared to youth whose parents have higher education. There is no negative effect of parental general secondary education for Estonians. This trend is reversed for Russians. Compared to those Russians whose parents have higher education, Russians with general secondary parental education have a lower probability of entering and completing higher education. Contrary to the findings for Estonians, there is no significant disadvantage for Russian youth whose parents have vocational and professional secondary education.

We added Estonian language skills and citizenship into the model for Russians, in order to check for the effect of country-specific human capital of parents on the probability of continuing and finishing studies in higher education. Surprisingly, there is some evidence that parents' rather poor Estonian language skills has a positive effect on the probability of attaining higher education, while poor language skills has no 
Table 4.5 Transition to higher education and finishing studies (versus not continuing studies in higher education after attainment of secondary education or entering to higher education, but not finishing studies): Logistic regression models

\begin{tabular}{|c|c|c|c|}
\hline & \multirow[t]{2}{*}{ Estonians } & \multicolumn{2}{|c|}{ Russians } \\
\hline & & Model 1 & Model 2 \\
\hline \multicolumn{4}{|l|}{ Gender } \\
\hline Male & $-.65 * *$ & -.58 & $-.68 *$ \\
\hline \multicolumn{4}{|l|}{ Female (reference group) } \\
\hline \multicolumn{4}{|l|}{ Age group } \\
\hline $18-25$ & $-1.92 * * * *$ & $-1.73 * * *$ & $-1.78 * \cdots * *$ \\
\hline \multicolumn{4}{|l|}{$26-35$ (reference group) } \\
\hline \multicolumn{4}{|l|}{ Region } \\
\hline Tallinn & .12 & -.01 & .06 \\
\hline \multicolumn{4}{|l|}{ Kohtla-Järve (reference group) } \\
\hline \multicolumn{4}{|l|}{ Parental occupational group } \\
\hline Manager, professional & .07 & 7.46 & 7.19 \\
\hline Lower non-manual worker & .29 & 7.15 & 6.91 \\
\hline Skilled manual worker & -.57 & 7.19 & 6.87 \\
\hline \multicolumn{4}{|l|}{ Unskilled manual worker (reference group) } \\
\hline \multicolumn{4}{|l|}{ Parental education } \\
\hline Primary, basic & $-1.20 *$ & -7.73 & -7.17 \\
\hline General secondary & -.74 & $-2.51 * * * *$ & $-2.34 * * * *$ \\
\hline $\begin{array}{l}\text { Vocational and professional } \\
\text { secondary }\end{array}$ & $-.89 * *$ & -.56 & -.50 \\
\hline \multicolumn{4}{|l|}{ Higher (reference group) } \\
\hline \multicolumn{4}{|l|}{ Type of secondary education } \\
\hline General secondary & .29 & 8.50 & 8.54 \\
\hline Vocational secondary & $-2.25 * * *$ & 4.80 & 4.78 \\
\hline \multicolumn{4}{|l|}{ Professional secondary (reference group) } \\
\hline \multicolumn{4}{|l|}{ Estonian language skills of parents } \\
\hline Poor skills & & & 28 \\
\hline Rather poor skills & & & $.99 *$ \\
\hline Rather good skills & & & 49 \\
\hline \multicolumn{4}{|l|}{ Good skills (reference group) } \\
\hline \multicolumn{4}{|l|}{ Parental citizenship } \\
\hline Both parents have Estonian citizenship & & & .55 \\
\hline One parent has & & & .15 \\
\hline \multicolumn{4}{|l|}{ Both have not (reference group) } \\
\hline Constant & .85 & -15.09 & -15.60 \\
\hline Pseudo R square & .34 & .42 & .44 \\
\hline Number of cases & 332 & 330 & 330 \\
\hline
\end{tabular}

***: Effect significant at $p<0.01$

$* *$ Effect significant at $p<0.05$

*Effect significant at $p<0.10$

Source: Own calculations based on TIES 
effect. The Estonian citizenship of parents has no effect on the odds of the second generation continuing studies after secondary education. Thus, contrary to our expectations, parental country-specific capital has a very small impact on the transitions of Russian youth in the educational system. This result can be explained by the existence of private higher education institutions with Russian language instruction, where Estonian language proficiency is not important.

\subsection{Conclusion}

Most researchers agree that tendencies of convergence or divergence between different ethnic groups are dependent on a set of contextual and historical conditions (Reitz I998). National contexts vary widely in the types of opportunities they offer to the second generation. Estonian society during the Soviet period was ethnically segmented, e.g. two parallel societies existed. The education system was also divided into two parts, based on the language of instruction. This parallelism inherited from the Soviet period might have an impact on the educational paths of different ethnic groups in contemporary Estonia.

In most traditional immigration countries, there are tendencies of convergence between natives and immigrants (Thomson \& Crul 2007). Generally, the first generation was positioned at the lower levels of the social hierarchy, particularly with regard to schooling and the labour market. This reflects a decrease in ethnic differences between the first and second generations. This is not the case in Estonia, where the dissimilarity of second-generation Russians' to Estonians, in terms of education, has increased compared to their parents' generation. There were very slight ethnic differences in the educational composition of the parental generation in favour of Russians. Ethnic inequalities have emerged for second-generation Russians as their situations have become more disadvantaged.

In Western European countries, social background appears to be an important explanation for ethnic differences in educational attainment. As expected in Estonia, this explanation does not adequately account for the educational differences between Estonians and Russians, because the first generation of immigrant population in Estonia is very different from the traditional low-educated first-generation immigrants in Western Europe. Their educational level was even somewhat higher compared with Estonians. However, this does not mean that the processes of social reproduction are not significant in Estonia. Social background influences the educational opportunities of Estonians and Russians, but it is not a factor behind the disadvantaged situation of second-generation Russians. 
We posit that changed institutional conditions have had the most significant impact on the second generation's educational attainment, by decreasing their possibilities of entering higher education. After I99I, instead of a gradual change in the education system, the government chose to start a quick transition to teaching only in the Estonian language in higher education institutions. At the same time, the quality of Estonian language instruction in Russian secondary language schools was rather poor. Although there are no legal restrictions limiting immigrants' access to any level of education, in practice higher education opportunities for people not proficient in Estonian are constrained. Russian youth attaining education in secondary school with Russian tuition can continue their studies in public higher education institutions that provide instruction mainly in Estonian or in private higher education institutions where they could study in Russian but they will pay a tuition fee. This means that Russian school-leavers without sufficient Estonian language skills, find themselves at a disadvantage in access to higher education. We suppose that the termination of public education in the Russian language at the secondary level, as well as decreasing follow-ups to higher educational institutions, has contributed to the lowering of the educational level of young Russians.

The occurrence of ethnic differences in educational transitions in Estonia can be seen to have a rational basis once the implications of the resources, opportunities, and constraints are taken into account. The special situation in Estonia, following structural changes and especially after the transition to Estonian language teaching in public higher education might have reduced actual opportunities, as well as the success expectations of Russian youth. Even where there are strong investment motives and the existence of resources, Russians are less likely to invest in education due to low success expectations. The threshold can only be only crossed if there is a clear increase in opportunities and success expectations. Data from the survey Integration of Estonian Society: Monitoring 2008 confirms that only a quarter of Russians think that their opportunities to attain higher education are equal to those of Estonians (Saar 2008). The perception of injustice may have an impact on the educational choices of Russian youth, who rationalise decisions not to try to enter higher education. Russians may adapt their choices to the perceived opportunity set. Adam Swift (2003) calls this process 'adaptive preference formation'. He indicates that even the belief that the mechanism of allocation is biased (in our case the belief that Estonians have better opportunities to attain higher education) is enough to make it rational not to try, no matter whether it is false or not (ibid.: 2II). Of course, the perceived opportunities are based on the actual opportunity set. In the Estonian case, the actual mechanisms and perceptions of them seem to be at work. 
Though educational investment represents one core factor in the stabilisation of ethnic inequalities, it is not the only mechanism. With an approximately constant supply of higher positions available on the labour market, the queue for better positions becomes longer, while the supply of (formally) qualified applicants devalues the educational certificates and, in turn, increases the relevance of symbolic qualification signals and of a certain kind of cultural capital (Boudon I974). In the case of immigrants, ethnic membership exacerbates the situation by counting as a (negative) symbol for the actual value of an education certificate.

According to the model of intergenerational integration, the attractiveness of investments in receiving country capital depends on economic opportunities within the host society, or on the cultural evaluation of education by immigrants. Hartmut Esser (2004) indicates that even if certain ethnic groups are able to ensure high success in education, ethnic inequalities may still appear in labour market success. This reduces the evaluation of education and the success expectations for the following generation, despite a certain degree of cultural assimilation, e.g. language acquisition. As a result, clear mobility restraints are to be anticipated. It is the stabilisation of ethnic inequalities. We fear this could happen in Estonia because there are differential returns on educational investments for Estonians and Russians (Leping \& Toomet 2008).

Recently, there have been some reforms in the Estonian education system, which might have an influence on the educational decisions of the second generation in future. Most public higher education institutions now offer a one-year advanced Estonian language course (with the provision of extra funding) to those students who have limited proficiency in Estonian and have a state-commissioned place. Other initiatives at the institutional level include the possibility of writing exams in Russian and the formation of groups of Russian students. The second generation we are focusing on here did not profit from these institutional initiatives to any reasonable degree. The transition to Estonian language studies in Russian language secondary schools, started in 2007, might have some impact on the educational opportunities of Russian youth. According to the survey Integration of Estonian Society: Monitoring 2008, Estonians are optimistic about the results of the transition, while the Russian population is considerably more pessimistic. Entitled Estonian Language Studies in Secondary Schools with Russian as the Language of Instruction: Awareness and Attitude of Russians and the Factors Influencing These, the survey indicates that Russian respondents agreed on the positive long-term impact of the transition. That is, increased opportunities for continuing their education and improved competitiveness of students from Russian language schools on 
the labour market, as a result of their Estonian language studies. Regardless of the potential positive effects, the transition is viewed as an added burden and the psychological stress for students, as well as the danger of incomplete knowledge was mentioned (Estonian Ministry of Education and Research 2009). However, surveys also indicated that there is a belief that Russian language schools are not prepared for teaching subjects in Estonian and that there are concerns about the preparedness of the schools for conducting subject teaching in Estonian. Transition to bilingual teaching in Russian secondary language schools may improve Russian youth opportunities for attaining higher education in the longer perspective. It probably takes some time for the effects to appear, although initially, the transition to bilingual studies may reduce the quality of education in these schools.

It is quite likely that a gradual transition of the education system, starting with the lower levels of education, could have avoided the situation of Russians being disadvantaged in access to higher education. Data from the survey Integration of Estonian Society: Monitoring 2008 shows that about two thirds of Russians support the idea that Estonian language studies should start in kindergarten. Others argue that Estonian language studies should start in primary school. There are very few Russians who believe that studies in Estonian should begin no earlier than basic or secondary school (Saar 2008).

In most Western European countries, social background influences the educational attainment of the ethnic minority and majority students in much the same way (see Heath \& Brinbaum 2007). Our results indicate that, in Estonia, the tendency is for parents' education and social position to be more important influences on the educational choices of minority youth. High social background might be essential for Russians to enter higher education, whereas Estonians might be able to enter higher education even in the absence of advantageous social origin.

Research in Western European countries has shown that one important reason why immigrants might fare badly in the labour market and why their descendants, the second generation, might also experience disadvantages is lack of fluency in the language of the destination country and, more broadly, the lack of country-specific human capital (Heath \& Cheung 2007). We do not find any distinct impact of Estonian language proficiency or Estonian citizenship of the parental generation on the educational opportunities of their children. In other words, in the Estonian context, the general human capital of parents is a more important factor than country-specific human capital of parents. The major cause of ethnic inequalities in the educational careers of the second generation seems to be the institutional organisation of the schooling 
system, which lowers ethnic minorities' actual and perceived opportunities for educational success.

Many authors indicate that with the establishment of ethnic inequalities, structurally grounded ethnic conflict taking various forms (from an emotional reactive ethnicity to forms of everyday ethnic hostility, attempts at political participation and the establishment of minority rights and separatist movements) will materialise (Hechter 2000; Esser 2004). According to Hartmut Esser (2003: 27), the prerequisite for ethnic conflict and political ethnification is an ethnic definition of the discrimination experienced, e.g. via the ethnic framing of a given structural situation. As previously noted, Russians perceive injustice in the education system. This may lead to comparatively high levels of reactive processes and the potential for ethnic conflict in Estonia.

\section{Notes}

I Up to I999, they could also opt for secondary specialised education.

2 The distinction between primary and secondary effects has been put forward with regard to class inequality in schooling (Boudon 1974). This distinction maps on to a distinction between the determinants of early-demonstrated ability and the determinants of continuation rates into secondary and tertiary education (controlling for test scores).

3 There were very few unskilled manual workers among the parental generation.

\section{References}

Alba, R.D., J. Handl \& W. Müller (I994), 'Ethnische Ungleiccheit in Deutschen Bildungssytem', Kölner Zeitschrift für Soziologie and Sozialpsychologie 46 (2): 209-237.

Borjas, G. J. (I995), 'Ethnicity, neighborhoods, and human-capital externalities', The American Economic Review 85 (3): 365-390.

Boudon, R. (I974), Education, opportunity, and social inequality: Changing prospects in western society. New York: Wiley.

Breen, R. \& J.H. Goldthorpe (I997), 'Explaining educational differentials: Towards a formal rational action theory', Rationality and Society 9 (3): 275-305.

Brinbaum, Y. \& H. Cebolla-Boado (2007), 'The school careers of ethnic minority youth in France', Ethnicities 7 (3): 445-474.

Caplan, N., M.H. Choy \& J.K. Whitmore (I99I), Children of the boat people: A study of educational success. Ann Arbor: University of Michigan Press.

Crul, M. \& H. Vermeulen (2003), 'The future of second generation: The integration of migrant youth in six European countries', Special issue of International Migration Review 37 (4): 965-II44.

Esser, H. (2003), 'Does the "new” immigration require a "new” theory of intergenerational integration?’, MZES Working Paper No. 7I. Mannheim: MZES.

Esser, H. (2004), 'Does the "new" immigration require a "new" theory of intergenerational integration?’, International Migration Review 38 (3): II26-II59. 
Fekjær, S. (2007), 'New differences, old explanations: Can educational differences between ethnic groups in Norway be explained by social background?', Ethnicities 7 (3): 367389 .

Gambetta, D. (1987), Were they pushed or did they jump? Individual decision mechanisms in education. Cambridge: Cambridge University Press.

Goldthorpe, J.H. (2000), On sociology: Numbers, narratives, and the integration of research and theory. Oxford: Oxford University Press.

Heath, A. \& Y. Brinbaum (2007), 'Guest editorial: Explaining ethnic inequalities in educational attainment', Ethnicities 7 (3): 29I-305.

Heath, A. \& S.Y. Cheung (2007), 'The comparative study of ethnic minority disadvantage', in A. Heath \& S. Y. Cheung (eds.), Unequal chances: Ethnic minorities in western labour market, I-44. Oxford: Oxford University Academy.

Heath, A. \& D. McMahon (2005), 'Social mobility of ethnic minorities', in C.G. Loury, T. Modood \& S.M. Teles (eds.), Ethnicity, social mobility and public policy, 393-4I3. Cambridge: Cambridge University Press.

Hechter, M. (2000), Containing nationalism. Oxford: Oxford University Press.

Helemäe J., E. Saar \& R. Vöörmann (2000), Kas haridusse tasus investeerida (Returns to education). Tallinn: Teaduste Akadeemia Kirjastus.

Helemäe, J. (2008), 'Tööalane eneseteostus ja selle võimaluste tajumine (Self-realisation at work and perceived opportunities for it)', in Integratsiooni monitoring 2008. Aruanne (Integration of Estonian Society, Monitoring 2008. Report). www.rahvastikuminister. ee/?id=I205I. Accessed I2 January 2008.

Hout, M. (2005), 'Educational progress for African-Americans and Latinos in the United States from the I950s to the I990s: The interaction of ancestry and class', in C.G. Loury, T. Modood \& S.M. Teles (eds.), Ethnicity, social mobility and public policy, 262287. Cambridge: Cambridge University Press.

Kalter, F. \& N. Granato (2002), 'Demographic change, educational expansion, and structural assimilation of immigrants: The case of Germany', European Sociological Review I8 (2): I99-2I6.

Kalter, F., N. Granato \& C. Kirsten (2007), 'Disentangling recent trends of the second generation's structural assimilation in Germany', in S. Scherer, R. Pollack, G. Otte \& M. Gangl (eds.), From origin to destination: Trends and mechanisms in social stratification research, 214-245. Frankfurt and New York: Campus.

Kao, G. (2004), 'Parental influences on the educational outcomes of immigrant youth', International Migration Review 38 (2): 427-449.

Kao, G. \& J.S. Thompson (2003), 'Racial and ethnic stratification in educational achievement and attainment', Annual Review of Sociology 29: 4I7-442.

Kao, G. \& M. Tienda (I995), 'Optimism and achievement: The educational performance of immigrant youth', Social Science Quarterly 76 (I): I-I9.

Kao, G. \& M. Tienda (I998), 'Educational aspirations of minority youth', American Journal of Education Io6 (3): 349-384.

Kristen, C. \& N. Granato (2007), 'The educational attainment of the second generation in Germany: Social origins and ethnic inequality', Ethnicities 7 (3): 343-366.

Kristen, C., D. Reimer \& I. Kogan (2008), 'Higher education entry of Turkish immigrant youth in Germany', International Journal of Comparative Sociology 49 (2-3): I27-I5I.

Kulu, H. (200I), 'Sõjajärgne sisseränne Eestisse võrdlevas perspektiivis (Post-war immigration in Estonia in comparative perspective)', Akadeemia II (I52): 2379-2395.

Leping, K.-O. \& O. Toomet (2008), 'Emerging ethnic wage gap: Estonia during political and economic transition', Journal of Comparative Economics 36 (4): 599-6I9.

Lindemann, K. (2008), 'Education', in Integration of second-generation Russians in Estonia: Country report on TIES survey in Estonia, 29-44. Tallinn: Institute of International and Social Studies, Tallinn University. 
Ministry of Education and Research (2009), Uuringud, statistika, andmebaasid (Surveys, statistics, databases), www.hm.ee/index.php?03264. Accessed I5 May 2009.

Modood, T. (2004), 'Capitals, ethnic identity and educational qualifications', Cultural Trends I3 (2): 87-IO5.

OECD (2006), OECD factbook 2006: Economic, environmental and social statistics. Paris: OECD.

OECD (2007), Review of tertiary education in Estonia. Paris: OECD.

Ogbu, J.U. (I997), 'Racial stratification and education in the United States: Why inequality persists', in A.H. Halsey, H. Lauder, P. Brown \& A. Stuart Wells (eds.), Education: Culture, economy, society, 765-778. Oxford: Oxford University Press.

Phalet, K., P. Deboosere \& V. Bastiaenssen (2007), 'Old and new inequalities in educational attainment: Ethnic minorities in the Belgian census I99I-200I', Ethnicities 7 (3): 390-4I5.

Platt, L. (2005), 'The intergenerational social mobility of minority ethnic groups', Sociology 39 (3): 445-46r.

Portes, A. \& L. Hao (2004), 'The schooling of children of immigrants: Contextual effects on the educational attainment of the second generation', Proceedings of the National Academy of Science IOI: IIg20-II927. Washington, D.C.: National Academy of Sciences.

Raftery, A.E. \& M. Hout (I993), 'Maximally maintained inequality: Educational stratification in Ireland', Sociology of Education 65 (I): 4I-62.

Reitz, J. (2002), Host societies and the reception of immigrants: Institutions, markets and policies. New York: Center of Migration Studies of New York.

Saar, E. (2008), 'Haridus' (Education), in Integratsiooni monitoring 2008. Aruanne (Integration of Estonian Society, Monitoring 2008. Report). www.rahvastikuminister. ee/?id=I205I. Accessed I2 January 2008.

Saar, E. \& M. Titma (1992), 'Migratsionsströme in sowjetisierten Baltikum and ihre Nachwirkung auf die baltischen Staaten nach Wiederherstellung der Selbsständigkeit'. Berichte des Bundesinstituts für Ostwissenschaftliche and internatinale Studien No. 9.

Saar, E. \& K. Lindemann (2008), 'Estonia', in I. Kogan, M. Gebel \& C. Noelke (eds.), Europe enlarged: A handbook of education, labour and welfare regimes in Central and Eastern Europe, I5I-I8I. Bristol: Policy Press.

Sue, S. \& S. Okazaki (I990), 'Asian-American educational achievements: A phenomenon in search of an explanation', American Psychologist 45 (8): 9I3-920.

Swift, A. (2003), 'Seizing the opportunity. The influence of preferences and aspirations on social immobility', New Economy Io (4): 208-212.

Thomson, M. \& M. Crul (2007), 'The second generation in Europe and the United States: How is the transatlantic debate relevant for further research on the European second generation?', Journal of Ethnic and Migration Studies 33 (7): I025-104I.

Van de Werforst, H. G. \& F. van Tubergen (2007), 'Ethnicity, schooling, and merit in the Netherlands', Ethnicities 7 (3): 4I6-444. 
Appendix 4.1 Stepwise logistic regressions: Model fit

\begin{tabular}{|c|c|c|c|c|c|c|}
\hline & Model 1 & Model 2 & Model 3 & Model 4 & Model 5 & Model 6 \\
\hline \multicolumn{7}{|l|}{$\begin{array}{l}\text { Transition to general } \\
\text { secondary education }\end{array}$} \\
\hline Ethnicity & $x$ & $x$ & $x$ & $x$ & $x$ & \\
\hline Gender, age, region & & $\mathrm{x}$ & $\mathrm{x}$ & $x$ & $\mathrm{x}$ & \\
\hline $\begin{array}{l}\text { Parental occupational } \\
\text { group }\end{array}$ & & & $x$ & $x$ & $x$ & \\
\hline Parental education & & & & $x$ & $\mathrm{x}$ & \\
\hline Interactions ethnicity* & & & & & $\mathrm{x}$ & \\
\hline Social origin & & & & & & \\
\hline Model fit & .01 & .11 & .15 & .17 & .18 & \\
\hline \multicolumn{7}{|l|}{$\begin{array}{l}\text { Transition to higher } \\
\text { education }\end{array}$} \\
\hline Ethnicity & $x$ & $x$ & $x$ & $x$ & $x$ & $x$ \\
\hline Gender, age, region & & $x$ & $x$ & $x$ & $\mathrm{x}$ & $x$ \\
\hline $\begin{array}{l}\text { Parental occupational } \\
\text { group }\end{array}$ & & & $x$ & $x$ & $x$ & $x$ \\
\hline Parental education & & & & $x$ & $\mathrm{x}$ & $x$ \\
\hline $\begin{array}{l}\text { Type of secondary } \\
\text { education }\end{array}$ & & & & & $x$ & $x$ \\
\hline $\begin{array}{l}\text { Interactions ethnicity* } \\
\text { Social origin }\end{array}$ & & & & & & $x$ \\
\hline Model fit & .04 & .15 & .20 & .23 & .36 & .40 \\
\hline
\end{tabular}

Source: Own calculations based on TIES 



\title{
5 Explaining different returns from human capital in the labour market
}

\author{
Kristina Lindemann
}

\subsection{Introduction}

Ethnic inequalities characterise most labour markets in Europe. The extent of ethnic inequality depends on the specific societal context, as well as the characteristics of ethnic groups. In many European countries, the disadvantaged labour market position of first-generation immigrants relates to their insufficient human capital, foreign qualifications and work experience (Heath \& Cheung 2007). However, the children of immigrants attain their education in the country of destination and most likely acquire similar aspirations for economic success as natives (Portes \& Zhou I993). Studies have shown that there is labour market assimilation across generations. Although the second generation probably experiences ethnic disadvantages in the labour market, it is to a lesser extent than the first generation (Heath 2007). On the other hand, intellectual, material and social resources tend to accumulate and can lead to ever greater advantages across generations, while the lack of resources also accumulate into frequently overwhelming difficulties (Portes, Fernandez-Kelley \& Haller 2005). The second generation's entry into the labour market has increasingly highlighted the question of how to explain the different labour market successes of ethnic groups. The research has called attention to different mechanisms of labour market functioning that may mediate ethnic disadvantage such as discrimination, the role of networks, structural constraints and the importance of country-specific human capital.

The integration of Russian youth - who largely belong among second-generation immigrants - into the labour market is one of the key issues in Estonian society. However, in the context of employment, it is important to note that there are some significant differences between first-generation immigrants in Estonia and other Western countries. First, at the time of their migration, the Estonian economy was integrated into the Soviet Union's state-controlled economic system. Firstgeneration immigrants did not have to compete with natives, as is often the case in the Western European labour market. Also significant is the 
fact that the first generation of Russians had a similar level of education as ethnic Estonians. Furthermore, after arriving in Estonia they were usually employed in professional or skilled occupations and they did not experience any status change due to immigration. However, the societal system changed and a market economy was introduced after Estonia regained its independence in I99I. These reforms placed many Russians in a more disadvantaged labour market situation compared with Estonians. Since that time, Russians have clearly been the less successful group in the labour market. The difficulties, which first-generation immigrants often have to face in Western labour markets, became real for many Russians in Estonia, (e.g. lack of language skills or useful social networks for finding a professional job). The important question is how these developments have influenced the opportunities of second-generation Russians for economic success, many of whom gained their education at the time of Estonian independence.

This chapter focuses on labour market integration and examines second-generation Russians' access to higher occupational positions in the Estonian labour market. This simple indicator of labour market positioning is used in several studies of ethnic inequalities as access to higher positions influences many other job characteristics like income, prestige and job security (Kalter, Granato \& Kristen 2007). Data from the Estonian Labour Force Surveys has shown that the labour market position of young Russians is more disadvantaged compared to Estonians. The aim of this chapter is to find out how extensive the differences are between natives and the second generation in terms of access to higher position explained by human capital. The main question is whether and why labour market returns from education differ for second-generation Russians and young Estonians. This chapter attempts to explain how second-generation labour market disadvantage is related to country-specific human capital, parental resources and social networks. The impact of structural conditions and labour market segmentation is also discussed.

\subsection{The Estonian context}

\subsubsection{Labour market developments}

Most immigrants arrived in Estonia during the Soviet Union period. Their main motivation for migration was employment. At that time, the Soviet state controlled and organised the labour force movement. Many newcomers settled in the industrial region of Ida-Virumaa County to work in the mining, chemical or textile industries. A large share of immigrants also came to live in Tallinn, where they worked in machine building, metal and light industries. These immigrants were mainly employed in the all-union enterprises, which were companies established by 
Moscow operating with imported raw materials from other parts of the Soviet Union. Many of the arriving immigrants were employed as skilled workers. In addition, all-union enterprises imported specialists and managers who had attained their education outside of Estonia. At the same time, Estonians were employed in enterprises of local importance, mainly in light industry. As Russians mostly settled in urban areas, the agricultural sector remained, for the most part, dominated by Estonians. Estonians were also overrepresented in the cultural, educational and academic fields (Luuk \& Pavelson 2002; Pettai \& Hallik 2002).

Thus, ethnic groups were employed in rather different segments. The ethnic segmentation of the economy was a by-product of the labour policy of the Soviet command economy. This long-term segmentation is also the basis of the current labour market segmentation. In addition, the networks of all-union enterprises and local enterprises were separated with almost no linkage between them. Communities of Estonians and Russians also remained separated under the new conditions. As a result, the social capital of ethnic groups is divided along ethnic lines (Luuk \& Pavelson 2002; Vöörmann \& Helemäe 2003).

Transition to a capitalist economy brought with it privatisation and the emergence of a labour market operating according to market principles. Erik André Andersen (I997) argues that Russians had poorer opportunities to participate in privatising small and medium-sized enterprises, because the legislation emphasised the importance of Estonian citizenship. In addition, the privatisation of large-scale enterprises took place via international auctions, in a bid to prevent Soviet era managerial staff from privatising the enterprises that they used to manage. Consequently, there were large numbers of international buyers (Lauristin \& Vihalemm I997). However, since the beginning of the transition, there have been less Russian entrepreneurs than Estonian ones (Pavelson \& Luuk 2002).

The employment situation in Estonia was substantially reformed in the first years of transition to a capitalist economy. The unemployment and inactivity rate started to increase in a developing labour market. In I992 and I993, approximately I00,000 people left the labour force (Eamets I999). One of the reasons was the outflow of Russians and other non-Estonians returning to their historic homelands. Generally, those who left had the resources to do so, and leavers often belonged among the most successful non-Estonians (Luuk \& Pavelson 2002).

Since the beginning of the I990s, Estonia has moved towards a postindustrial service economy. The share of the primary sector has declined drastically and the importance of the service sector has increased since the start of profound economic reforms (Eamets 2008). Figure 5.I indicates that the restructuring of the economy influenced Estonians and non-Estonians (official statistics present data as differentiated 
Figure 5.1 Estonians and Russians employed in the primary, secondary and tertiary sectors in 1989, 1994 and 2008 (in \%)

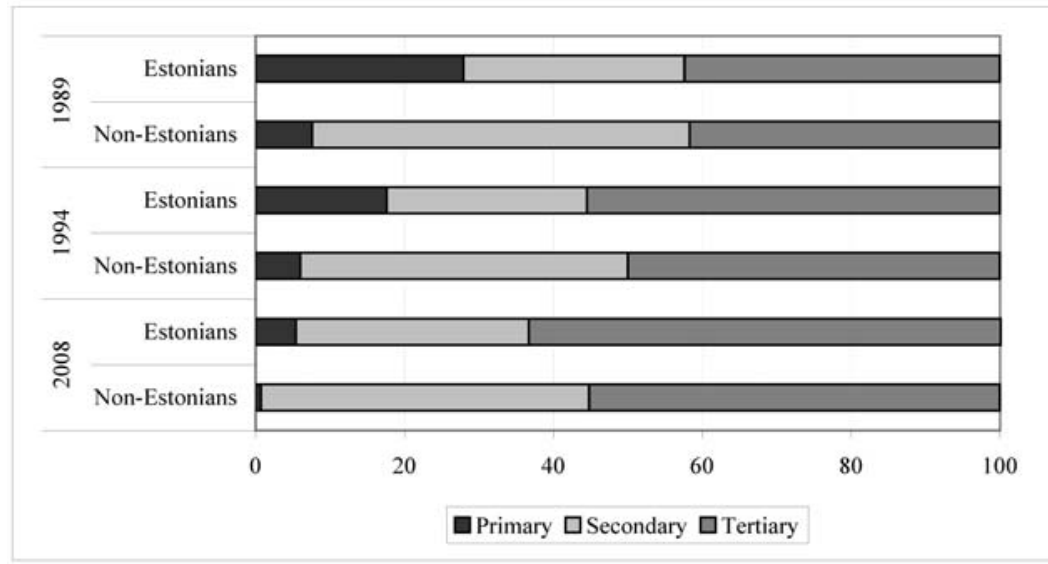

Source: Statistics Estonia 2009

between Estonians and non-Estonians, among whom Russians are the most numerous albeit not the only ethnic group) in different ways. The employment opportunities of Estonians were strongly affected by the decline of the agricultural sector, while the Russians' labour market situation was influenced by structural changes in industry (Pavelson 2000). Many Russian speakers experienced a decline in employment opportunities because the all-union industries deteriorated during the transition years, as the former Soviet Union market no longer supplied raw materials and marketing opportunities. The reorganisation of the economy meant that a significant share of the labour force had to acquire new qualifications (Eamets I999). In 2008, Russians are still clearly more often employed in the industrial sector, but lagging behind Estonians in the tertiary sector.

Economic reforms led to a rise in unemployment. Joblessness started to grow in 1992 and since that time, the unemployment rate amongst Russians has exceeded that of ethnic Estonians. Reforms in the economy also influenced the occupational structure of the labour market. The percentage of non-Estonians working in higher positions has decreased and the number of ethnic Estonians working as managers and professionals has increased (Table 5.I). In 1989, 26 per cent of Estonians and 22 per cent of non-Estonians worked as managers or professionals, while data for I994 shows a slight change in these numbers. However, in 2008, 30 per cent of ethnic Estonians and only I8 per cent of nonEstonians were employed in managerial and professional positions. 
Table 5.1 Occupational status of Estonians and non-Estonians in 1989, 1994 and 2008 (in \%)

\begin{tabular}{|c|c|c|c|c|c|c|}
\hline & \multicolumn{2}{|r|}{1989} & \multicolumn{2}{|r|}{1994} & \multicolumn{2}{|r|}{2008} \\
\hline & Estonians & Non-Estonians & Estonians & Non-Estonians & Estonians & Non-Estonians \\
\hline Managers & 12 & 10 & 14 & 10 & 14 & 8 \\
\hline Professionals & 14 & 12 & 13 & 10 & 16 & 10 \\
\hline Specialists & 11 & 9 & 12 & 10 & 14 & 10 \\
\hline $\begin{array}{l}\text { Clerks, service } \\
\text { and sales } \\
\text { workers }\end{array}$ & 12 & 14 & 16 & 14 & 18 & 18 \\
\hline $\begin{array}{l}\text { Skilled } \\
\text { workers }\end{array}$ & 44 & 46 & 36 & 44 & 29 & 40 \\
\hline $\begin{array}{c}\text { Unskilled } \\
\text { workers }\end{array}$ & 7 & 9 & 8 & 12 & 8 & 14 \\
\hline
\end{tabular}

Source: Statistics Estonia 2009

One reason for the decreasing share of non-Estonians in managerial positions is that the first years of independence saw the replacement of Soviet era managers in the public sector. In these changed circumstances, non-Estonians were not successful in competing for managerial positions not least because Estonian language skills became increasingly important (Pettai \& Hallik 2002). In addition, the gap between Estonians and non-Estonians working as skilled or unskilled labourers has increased during the last two decades. Furthermore, the Estonian Labour Force Survey for the years 200I-2007 shows that non-Estonians are more likely to hold a job that does not match their level of education (Helemäe 2008).

The labour market situation stabilised in the middle of the I990s when economic well-being in terms of GDP started to increase. However, the economic crisis in Russia at the end of the I990s affected the economic situation in Estonia, again resulting in a rise in unemployment (Bank of Estonia 2008; Statistics Estonia 2009). Between 200I and 2007 , Estonia experienced a rapid improvement of economic conditions, which led to more favourable labour market conditions. The fast economic growth brought with it a decrease in the youth unemployment rate. However, the disadvantage of non-Estonian youth compared to ethnic Estonians has increased even during these years of economic growth. According to the Estonian Labour Force Survey data, there was only a small difference in the rates of unemployment for Estonians and nonEstonians in 200I, while in 2005, young non-Estonians were about three times more likely to be jobless and, in 2007 , this difference was I.6 times (Helemäe 2008). On the other hand, the overrepresentation of young Estonians in top labour market positions decreased during the economic boom. Data from the Estonian Labour Force Survey shows that 
in 200I, about 27 per cent of Estonian and ro per cent of non-Estonians worked as managers and professionals, while in 2006, these percentages were 30 per cent and I7 per cent, respectively (Lindemann \& Saar 2009).

\subsubsection{Labour markets in Tallinn and Kohtla-Järve}

The TIES survey was carried out in Tallinn and Kohtla-Järve, two cities with rather different economic environments. Tallinn is the largest city in Estonia and plays a significant role in the Estonian economy as an important centre for trade, communication and transportation. Many institutions of public administration are located in Tallinn. In 2007, about 69 per cent of employed people worked in the tertiary sector of the economy and 30 per cent were employed in the secondary sector (Statistical Yearbook of Tallinn 2007). The average monthly gross wage was I3 per cent higher in Tallinn than the national average in 2007 . The unemployment rate was only 3.4 per cent and the employment rate of 69 per cent exceeded the Estonian average (Statistics Estonia 2009).

Kohtla-Järve is an industrial town in Ida-Virumaa County. The economy of Kohtla-Järve is largely based on the extraction and processing of oil shale. The oil-shale industry was already established before World War II, but was rapidly expanded after the war to meet Soviet Union energy and chemical requirements. The expansion of this industry brought many new immigrants to Kohtla-Järve (Mettam \& Williams 200I). As the economy in Ida-Virumaa County was mainly targeted towards manufacturing for all-union needs and not for the Estonian local segment, the economy needed substantial reorganisation in the I99os. This has constrained labour market opportunities and living standards for people in the region. In 2007, the average monthly wage in IdaVirumaa County was only 74 per cent of the Estonian average monthly wage. The unemployment rate was 9 per cent, which was two times higher than the Estonian average, and the employment rate was only 57 per cent (Statistics Estonia 2009). Today, the chemical industry remains the most important branch of industry in Kohtla-Järve. In 2000, 24 per cent of employed people worked in manufacturing and 16 per cent worked in mining and quarrying (data from population census 2000).

The occupational structure of labour markets in Tallinn and the towns of Ida-Virumaa County differ to some extent (Table 5.2). In Tallinn, more people are working in managerial, professional or specialist positions, while the share of skilled workers is higher in the towns of Ida-Virumaa County. Ethnic differences seem to be greater in Tallinn. Estonians are almost twice as often employed in managerial and professional positions than non-Estonians are. Almost half of ethnic minorities hold the lowest positions in the labour market, working as skilled or unskilled workers. Similar tendencies also appear in the 
Table 5.2 Occupational status of employed persons in Tallinn and towns of IdaVirumaa County (in \%)

\begin{tabular}{|c|c|c|c|c|}
\hline & \multicolumn{2}{|c|}{ Tallinn } & \multicolumn{2}{|c|}{ Towns in Ida-Virumaa County } \\
\hline & Estonians & Non-Estonians & Estonians & Non-Estonians \\
\hline Managers & 19 & 10 & 11 & 9 \\
\hline Professionals & 20 & 11 & 12 & 10 \\
\hline Specialists & 19 & 13 & 16 & 12 \\
\hline $\begin{array}{l}\text { Clerks, service and } \\
\text { sales workers }\end{array}$ & 20 & 19 & 20 & 15 \\
\hline Skilled workers & 15 & 32 & 29 & 42 \\
\hline Unskilled workers & 6 & 16 & 9 & 12 \\
\hline $\mathrm{N}$ & 102,923 & 75,552 & 7,462 & 49,464 \\
\hline
\end{tabular}

Source: Population census 2000

towns of Ida-Virumaa County, although differences between ethnic groups are not as sharp there.

\subsection{Theoretical approaches and hypothesis}

\subsubsection{The influence of social background}

The literature about segmented assimilation argues that parental resources and family are important factors influencing into which segments of society the second generation will assimilate. Parental resources are necessary for promoting educational and labour market success and for avoiding downward assimilation. These resources provide access to economic goods and job opportunities. Parents with higher levels of education have more information about opportunities and pitfalls in the surrounding environment and they earn a higher income, which provides access to strategic goods (Portes 2005).

Patterns of ethnic disadvantage might parallel patterns of class fluidity, which means that ethnic penalties might be explained by the process of social reproduction (Heath 2007). Parental resources may influence the occupational status of the second generation through educational attainment. However, variations in parental background does not explain educational differences between ethnic groups in Estonia as first-generation immigrants were not negatively selected in terms of their human capital (see Lindemann \& Saar in this volume). Besides shaping educational attainment, parental resources might be an important factor in explaining the different labour market success of natives and the second generation (Nielsen, Rosholm, Smith \& Husted 2003). This means that parental resources also have a direct impact on the labour market success of children, which is not mediated through 
educational attainment. For instance, parents with a higher socio-economic position have more opportunities to mobilise their resources for their children's job search (Kalter et al. 2007). Therefore, higher parental education may increase the odds of attaining higher occupational status in the labour market. On the other hand, the labour market situation of Russians became more difficult at the beginning of the I99os in Estonia. In the changed circumstances, it turned out to be more complicated for the Russian minority to employ their human capital in the labour market. Hence, it is supposed that Russian youth gain less from higher parental resources than Estonians. At the same time, the importance of Estonian language skills for labour market success has increased. Therefore, it is expected that Estonian-proficient parents may have more resources to help their children to find good employment and provide access to higher positions.

\subsubsection{Human capital}

The theory of human capital predicts that labour market success can be explained as the return to investment in education, skills and workrelated experience (see e.g. Becker I962). Education has proven to be a crucial resource for youth in job competition in European countries. Education is particularly important at the start of a working career, as young people often do not have significant work experience (Müller \& Gangl 2003). Although education should have a major influence on labour market success, the returns from education may differ for natives and minorities.

One reason for different labour market returns from education is the importance of country-specific human capital. The concept of countryspecific human capital is based on the idea that certain aspects of human capital are more useful in some labour markets than in others. This means that country-specific human capital is not perfectly transferable across labour markets (Chiswick I978; Friedberg 2000; Kalter \& Kogan 2006). One of the most crucial aspects of country-specific human capital is proficiency in the host country language. Language skills may be necessary for fulfilling work tasks, as some jobs require the ability to speak and write in the host country language. In addition, knowledge of the language provides a broader spectrum of job opportunities. More proficient language speakers have greater access to information about jobs and they are able to relate their qualifications to potential employers better. The evidence from Germany and the UK shows that writing abilities in the host country language increase labour market outcomes compared to only oral proficiency (Dustmann I994; Dustmann \& Fabbri 2003). 
In Estonia, the change in the societal order in I99I brought with it a change in the valuation of certain aspects of human capital. The importance of Estonian language skills for labour market success rose very quickly, leaving Russians with insufficient language proficiency in a disadvantaged position. Many studies expect that second-generation immigrants who have attained education in public schools in the receiving society are usually fluent in the host country language (see e.g. Portes et al. 2005; Alba 2005; Heath \& Cheung 2007). Although most secondgeneration Russians completed their studies during Estonian independence, many of them still lack Estonian language skills. According to the survey Integration of Estonian Society: Monitoring 2008, about 27 per cent of Russian youth estimate their Estonian skills as fluent (Vihalemm 2008). Proficiency in the Estonian language is a significant precondition for access to professional jobs. In some cases, Estonian language proficiency is even required by law in public, as well as in some private, sector jobs. Hence, it is presumed that the ability to write in Estonian is important for getting higher occupational positions in the labour market.

The language of studies in school might also be an important aspect of country-specific human capital. Public schools that give basic and secondary education are divided, according to the language of instruction, into Estonian or Russian schools. At the level of higher education, generally it is only possible to study in Russian in private educational institutions. About half of those who leave Russian secondary schools and choose to continue their education do so in the Estonian language (Estonian Ministry of Education 2008). Such a divided educational system means that many Russians and Estonians study in separate schools, at least until completing secondary education. In general, secondary school graduates from Estonian and Russian schools receive similar scores on standardised state exams (with some exceptions) (see Lindemann \& Saar in this volume). Therefore, it can be presumed that in terms of teaching quality, these schools do not differ much. Nevertheless, studying in the Estonian language may mean better knowledge of the Estonian language related to a profession, experience of working in an Estonian language environment, as well as more connections with ethnic Estonians. Thus, it is presumed that besides good Estonian language skills, studying in the Estonian language is an important aspect of country-specific human capital that increases the odds of attaining higher occupational positions.

Second-generation Russians may not have Estonian citizenship, which is also an important aspect of country-specific human capital. Citizenship gives access to the civil service in many societies and, while these jobs might not be numerically large, they may be important avenues of advancement for ethnic minorities (Heath 2007). Citizenship is 
also necessary in Estonia for working in higher positions in the civil service. Thus, Estonian citizenship might be an important factor that influences second-generation odds of getting higher occupational positions.

\subsubsection{Structural factors: labour market conditions and networks}

The extent to which education and language skills can be used effectively in the labour market depends on the broader social context. Contextual effects interact with human capital to determine the extent to which it is useful for economic success (Portes I995). Local labour market conditions might have a significant influence on second-generation opportunities.

In general, the labour market situation in Tallinn is more favourable in terms of higher salaries, employment rate and higher share of people working in managerial, professional and specialist positions. This also means that the supply of highly qualified labour is larger in Tallinn. Despite a generally favourable economic situation, the gap between the occupational status of ethnic groups is much larger in Tallinn than in Ida-Virumaa County. According to the population census 2000, Estonians work about twice as often as managers and professionals in Tallinn compared to Russians (Statistics Estonia 2009). It is presumed that these general labour market characteristics also have an effect on second-generation opportunities. It is expected that access of Estonians and Russians to higher positions is related to the city where they live.

In addition, second-generation immigrants may be connected, through social and ethnic networks, to the economic sectors where their parents worked and thus, often end up in same sector (Kogan 2007). There is significant ethnic segmentation in the Estonian labour market. Russians tend to work more often in the industrial sector. It is presumed that labour market ethnic segmentation also influences secondgeneration labour market opportunities. The industrial sector does not offer as many opportunities to achieve higher occupational positions compared to business, service and social service. Therefore, the more restricted access to higher positions of the second generation might be related to the economic sector they work in.

Usually, immigrants possess certain ethnic group capital such as proficiency in their previous home country language and access to ethnic networks. Contrary to receiving country capital - that is generalised capital, which is highly efficient within the whole society - the usefulness of ethnic capital depends on special circumstances. If there is an ethnic community, it may be a reasonable option to use generally less efficient ethnic capital, for instance when investing in ethnic businesses or developing ethnic networks (Esser 2003). Working together with Russian colleagues gives the second generation opportunities to use their ethnic 
capital in terms of Russian language skills. The lack of Estonian-specific human capital might not be a hindrance in Russian businesses if it is not directly necessary for fulfilling job tasks. On the other hand, businesses owned by Russian minority members are concentrated in the secondary sector and in the wholesale and retail trade. What lies behind this segmentation is not the use of ethnic capital, but rather, it is a consequence of the structural conditions and regulations that did not let Russian managers take advantage of their positional capital after changes in the economic system (Vöörmann \& Helemäe 2003). The survey Integration of Estonian Society: Monitoring 2008 shows that Russian speakers working in Russian enterprises are less satisfied with their work than Russian speakers working in Estonian enterprises or in the public sector. They seldom have high occupational positions and often their educational level does not correspond to their job (Helemäe 2008). Due to the specific character of Russian enterprises, it is supposed that working together with Russian colleagues does not give any significant advantage to Russians for attaining higher occupational positions.

Networks of interpersonal relations affect several aspects of economic life, such as labour market behaviour and the opportunities of individuals (Granovetter I985). Ethnic minorities and natives may possess unequal social capital for success in the mainstream economy. Social capital inequality may offer fewer opportunities for minority members to mobilise social resources for economic success (Lin 1999). Another possible consequence of the lack of bridging links between minorities and natives is a lack of knowledge by minorities about opportunities outside of their ethnic community (Heath 2007). Estonian and Russian communities were separated during the Soviet period. Under new conditions, these lines of separation are still evident, meaning that the social capital of ethnic groups differs. The lack of social networks is one significant obstacle for Russians to compete with Estonians, as their networks have not been efficient for providing labour market success (Luuk \& Pavelson 2002). On the other hand, social networks may change character across generations, as young people have more opportunities to meet natives in school and university (Heath \& Cheung 2007). Due to the separated educational system, it is probable that the character of ethnic networks has not changed significantly across generations in Estonia and many second-generation Russians do not have Estonian friends. Still, the ethnic structure of the friendship network might be important, as having Estonian friends provides greater access to jobs in the other ethnic community. Thus, it is expected that having Estonian friends increases second-generation odds of achieving a higher occupational position. 


\subsection{Variables and method}

The dependent variable is the current or last occupational position. It is recorded, according to the ISCO-88 scale, into a dichotomous variable, which indicates whether the respondent belongs to the occupational group of managers, professionals and specialists (digits I to 3 on the ISCO-88 scale) versus other occupational groups (digits 4 to 9 on the ISCO-88 scale).

Independent variables describing demographic characteristics are ethnicity, gender and age group. Ethnicity is self-estimated and indicates whether the respondent is second-generation Russian or native Estonian.

Language skills and highest attained educational level of parents describes the respondent's socio-economic background. The latter variable distinguishes between whether the highest parental education is higher education or lower educational level. In order to measure the human capital of the respondent, the highest attained educational level at the time of interview is included in the analysis. The sample also includes respondents who are still students at the time of the interview, but who have already found a job.

Variables that refer to the structural conditions of the labour market and segmentation are city, industry and mother tongue of colleagues at work. The branch of industry where the respondent currently works or where they were last employed is recoded into three categories: I) manufacturing, construction and transport; 2) trade and service; 3) business service and social service. The mother tongue of colleagues shows which language environment the respondent works in and indirectly refers to whether the respondent works in an Estonian or Russian business. Whether the mother tongue of most of the respondent's colleagues is Russian, Estonian or mixed is specified.

The variables describing country-specific human capital are Estonian language writing skills, language of instruction during studies and citizenship. The self-estimated skill of writing in Estonian is chosen as the indicator of Estonian language skill, because the ability to write in Estonian is often required in higher occupation positions. In addition, the language of instruction during studies is added into the analysis. This variable indicates whether the respondent has ever studied in the Estonian language or not. In Table 5.3, the cross-tabulation analysis shows that conducting studies in Estonian does not mean that respondents give highest estimation to their Estonian language writing skills. Moreover, respondents who have never studied in Estonian may give high estimation to their Estonian writing skills. In addition, whether the respondent has Estonian citizenship or not is taken into account. Similarly, having Estonian citizenship does not mean that the respondent has very good 
Table 5.3 Estonian language writing skills by other type of country-specific human capital (in \%)

\begin{tabular}{lccc}
\hline & \multicolumn{3}{c}{ Estonian language writing skills } \\
\cline { 2 - 4 } & Very good & Good & Moderate or poor \\
\hline No studies in Estonian & 19 & 39 & 43 \\
Studies in Estonian & 44 & 34 & 23 \\
Non-Estonian citizen & 15 & 32 & 54 \\
Estonian citizen & 32 & 42 & 26 \\
\hline
\end{tabular}

Source: Own calculations based on TIES

language skills and a person with undetermined citizenship may also give high estimation to their Estonian abilities.

The share of Estonian friends is the measure for the ethnic composition of friendship networks, which refers to the ethnic segmentation of the social network. As the majority of respondents did not have many Estonian friends the variable indicates whether the respondent has none, a few or some Estonian friends.

Logistic regression analysis is used to conduct the empirical analysis. As a first step, a general model for Estonians and Russians is carried out in order to estimate ethnic differences in odds of attaining higher occupational position. In addition, the predicted probabilities of achieving managerial, professional or specialist position are calculated for both ethnic groups with different educational levels. The second step of the analysis is attempting to explain the disadvantage of Russians in the labour market. A separate logistic regression analysis is carried out for Russians in order to estimate the importance of country-specific human capital and structural conditions. Furthermore, separate models for Estonians and Russians with comparable variables are presented.

\subsection{Results}

\subsubsection{Odds for ethnic groups' labour market success}

In general, it appears that the share of youth working in higher positions is relatively large, as the TIES survey was conducted in cities not in rural areas (Figure 5.2). Young Estonians attain managerial and professional positions twice as often as second-generation Russians. In addition, Estonians more frequently achieve specialist positions than Russians do. In total, 4I per cent of young Estonians and 23 per cent of second-generation Russians get managerial, professional or specialist jobs. Therefore, it seems that Estonian youth perform much better in the labour market compared to Russians. 
Figure 5.2 The occupational status of Estonians and second-generation Russians in Tallinn and Kohtla-järve (in \%)

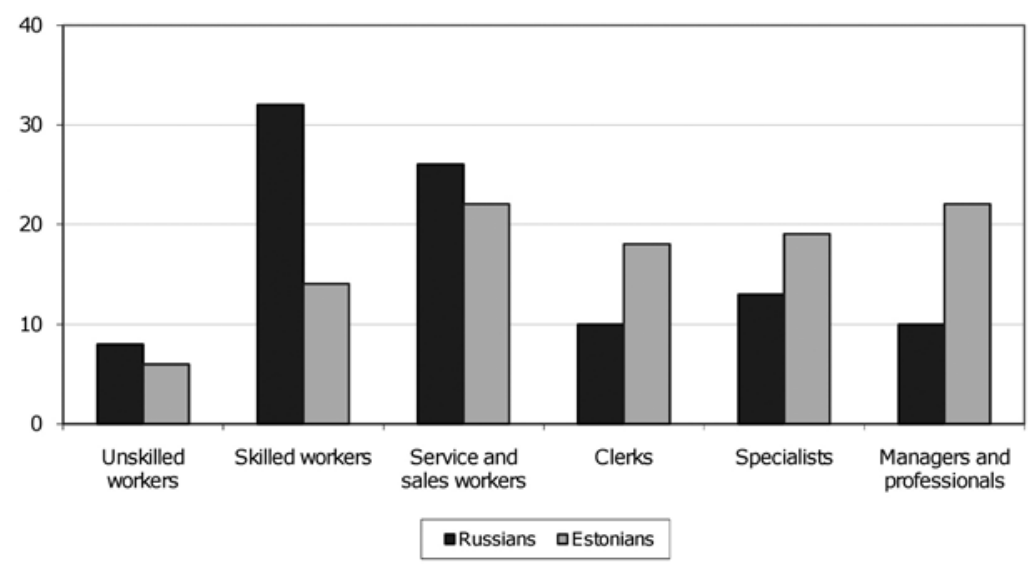

Source: Own calculations based on TIES

Table 5.4 presents the results of the logistic regression analysis. An estimate is made of the influence of ethnicity and other characteristics on the odds of reaching a managerial, professional or specialist position compared with the probability of getting a lower labour market position. The first model only includes ethnicity and it appears that Russians have significantly lower odds of reaching a higher position in the labour market. In the second model, gender, age group and parental highest education are added into the analysis. As expected, the younger age group is less likely to be in higher occupational positions, which can be explained by their shorter labour market experience. Parental education has a significant effect on current labour market position. The children of higher educated parents are more likely to get higher labour market returns. The influence of ethnicity even increases slightly once parental education is added to the model, indicating that in the case of similar parental education Russian disadvantage is even larger compared to Estonians.

The third model is the model of human capital and includes the respondent's education level. It appears, as expected, that higher educational level increases the probability of attaining managerial, professional or specialist positions. However, controlling human capital does not reduce second-generation Russians' disadvantage compared to their Estonian peers. In spite of similar educational levels, the odds of Russians getting a higher occupational position are lower. Interestingly, there is still a significant effect from parental educational level. This 
Table 5.4 Access to managerial, professional and specialist positions, logistic regression model, $N=646$

\begin{tabular}{|c|c|c|c|c|}
\hline & $\begin{array}{l}\text { Ethnicity } \\
\text { model }\end{array}$ & $\begin{array}{l}\text { Model with } \\
\text { parental resources }\end{array}$ & $\begin{array}{l}\text { Human capital } \\
\text { model }\end{array}$ & $\begin{array}{l}\text { Structural } \\
\text { model }\end{array}$ \\
\hline \multicolumn{5}{|l|}{ Ethnicity } \\
\hline Russian & $-0.78 * * * *$ & $-0.89 * * *$ & $-0.77 * * * *$ & $-0.70 * * *$ \\
\hline \multicolumn{5}{|l|}{ Estonian (reference group) } \\
\hline \multicolumn{5}{|l|}{ Gender } \\
\hline Men & & $-0.36 *$ & -0.09 & 0.11 \\
\hline \multicolumn{5}{|l|}{ Women (reference group) } \\
\hline \multicolumn{5}{|l|}{ Age group } \\
\hline $18-25$ & & $-1.08 * * *$ & $-0.84 * * * *$ & $-0.82 * * *$ \\
\hline \multicolumn{5}{|l|}{ 26-35 (reference group) } \\
\hline \multicolumn{5}{|l|}{ Parental education } \\
\hline Higher & & $1.10 \% * \%$ & $0.65 \% *$ & $0.61 *$ \\
\hline \multicolumn{5}{|l|}{ Lower (reference group) } \\
\hline \multicolumn{5}{|l|}{ Education } \\
\hline Basic or less & & & $-0.87 * *$ & $-0.92 * *$ \\
\hline $\begin{array}{l}\text { Vocational or professional } \\
\text { secondary }\end{array}$ & & & $-0.45 *$ & -0.43 \\
\hline Higher & & & $1.81 * \cdots$ & $1.60 * \cdots$ \\
\hline \multicolumn{5}{|l|}{$\begin{array}{l}\text { General secondary } \\
\text { (reference group) }\end{array}$} \\
\hline \multicolumn{5}{|l|}{ Region } \\
\hline Tallinn & & & & 0.01 \\
\hline \multicolumn{5}{|l|}{$\begin{array}{l}\text { Kohtla-Järve } \\
\text { (reference group) }\end{array}$} \\
\hline \multicolumn{5}{|l|}{ Branch of industry } \\
\hline $\begin{array}{l}\text { Manufacturing, construction } \\
\text { and transport }\end{array}$ & & & & 0.54 \\
\hline $\begin{array}{l}\text { Business service and } \\
\text { social service }\end{array}$ & & & & $1.40 * \cdots *$ \\
\hline \multicolumn{5}{|l|}{$\begin{array}{l}\text { Trade and service } \\
\text { (reference group) }\end{array}$} \\
\hline \multicolumn{5}{|l|}{ Mother tongue of colleagues } \\
\hline Russian & & & & -0.18 \\
\hline Mixed & & & & -0.18 \\
\hline \multicolumn{5}{|l|}{ Estonian (reference group) } \\
\hline Constant & -0.38 & -0.24 & -0.59 & -1.38 \\
\hline Pseudo R square & 0.03 & 0.10 & 0.24 & 0.27 \\
\hline
\end{tabular}

***:*ffect significant at $p<0.01$

$* *$ Effect significant at $p<0.05$

*Effect significant at $p<0.10$

Source: Own calculations based on TIES 
suggests that social background has a direct effect on labour market success that is not mediated through educational attainment.

Characteristics describing structural conditions are included in the next model. The aim of this model is to analyse whether city, branch of industry and mother tongue of colleagues are related to youth occupational position. It appears that only branch of industry has significant influence on the odds of belonging to the higher occupational group. Adding these labour market segmentation characteristics into the model does not change the significant effect of ethnicity. This indicates that second-generation Russians' disadvantage is not caused by the industry they work in or by the city they live in. Working in an Estonian or Russian company does not explain the effect of ethnicity. Furthermore, the mother tongue of colleagues has no significant effect on the opportunity to reach a higher occupational status. Therefore, it seems that even Russians who only work, mostly, with other Russians still experience disadvantages in access to higher occupational positions. This might be explained by the general lower upward mobility opportunities in such enterprises.

In order to examine how educational returns differ for Estonians and Russians, the predicted probabilities of attaining a higher occupational position were calculated for each educational level. Calculations were done based on the structural model presented in Table 5.4. Added interaction effects indicate dissimilarity in returns from education for Estonians and Russians (interactions not presented here). Figure 5.3

Figure 5.3 Predicted probabilities for Russians and Estonians with different educational levels to attain a managerial, professional or specialist position (other independent variables are set to mean)

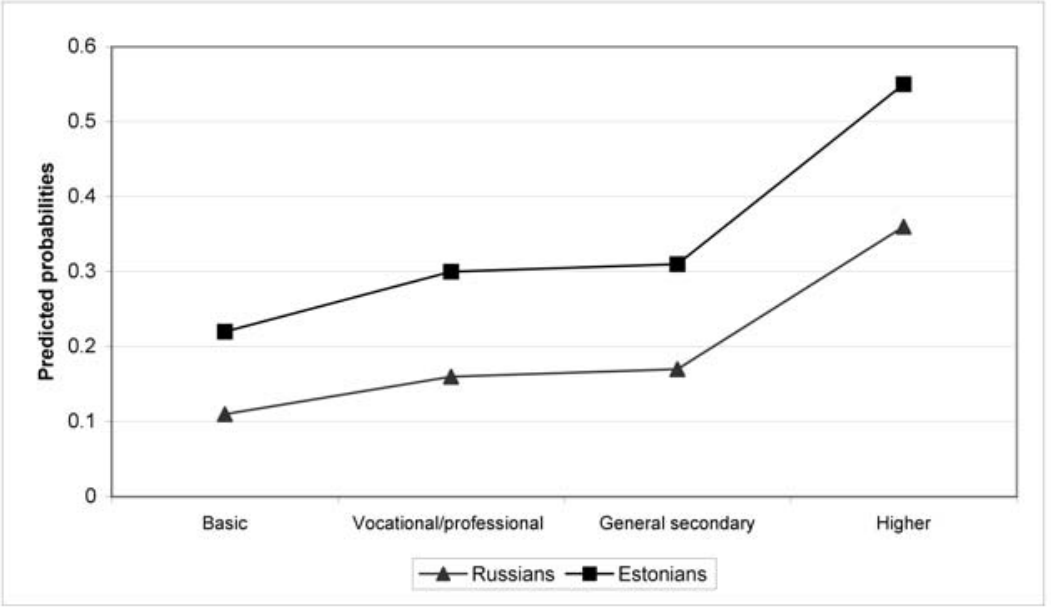

Source: Own calculations based on TIES 
indicates that respondents with basic education have a very low probability of getting a managerial, professional or specialist position in both ethnic groups. Attaining vocational/professional or general secondary education increases the probability of achieving a higher occupational position, particularly for Estonians. Attaining higher education significantly increases the success probability for both ethnic groups. However, the gap between ethnic groups is largest among youth with higher education. Second-generation Russians with higher education have an obvious disadvantage in achieving a good labour market position compared to natives with a similar educational level.

\subsubsection{Which resources are significant for Russians to be successful in the labour market?}

Second-generation Russians are a heterogeneous group in terms of their resources. Separate regression models for Russians are estimated in order to find out which resources influence opportunities for achieving higher occupational status and who are most successful in the labour market. Table 5.5 includes characteristics of country-specific human capital and networks. The first model includes parental resources and demographic characteristics. This model takes into account parental education and the Estonian language skills of parents. It appears that the Estonian language proficiency of parents does not influence secondgeneration Russians probabilities of achieving a higher position in the labour market. In the first model, parental education has a strong effect, but the strength of this effect decreases once an individual's own educational level is included into the analysis. Therefore, it seems that in the case of second-generation Russians, the influence of parental education is mediated by the educational attainment of an individual and there is no direct influence. In addition, separate logistic regression models for Estonians and Russians were carried out (Appendix 5.I). It appears that in the case of all other characteristics being equal, parental educational attainment has no significant effect on Russian youth opportunities, which means that higher parental background does not give a significant advantage to Russians compared with lower parental background. On the other hand, there is a positive influence of parental higher educational background for young Estonians, indicating that children who have more educated parents are likely to achieve higher occupational status. In addition to individual educational level, Estonian language writing skills are significant for getting managerial, professional or specialist positions in the labour market (Table 5.5). Russians with very good Estonian language writing skills are the most advantaged group compared to those with less ability in Estonian. 
Table 5.5 Second-generation Russians' access to managerial, professional and specialist positions, logistic regression model, $N=294$

\begin{tabular}{|c|c|c|c|}
\hline & $\begin{array}{l}\text { Model with } \\
\text { parental resources }\end{array}$ & $\begin{array}{l}\text { Human } \\
\text { capital model }\end{array}$ & $\begin{array}{l}\text { Structural } \\
\text { model }\end{array}$ \\
\hline \multicolumn{4}{|l|}{ Gender } \\
\hline $\begin{array}{l}\text { Male } \\
\text { Female (reference group) }\end{array}$ & -0.42 & 0.74 & $1.66 * * *$ \\
\hline \multicolumn{4}{|l|}{ Age group } \\
\hline $18-25$ & $-1.03 *$ * & $-1.51 * * *$ & $-1.68 * * *$ \\
\hline \multicolumn{4}{|l|}{$26-35$ (reference group) } \\
\hline \multicolumn{4}{|l|}{ Parental education } \\
\hline Higher & $1.42 * * *$ & 0.44 & 0.53 \\
\hline \multicolumn{4}{|l|}{ Lower (reference group) } \\
\hline \multicolumn{4}{|l|}{ Estonian language skills of parents } \\
\hline Rather good skills & -0.33 & $-0.93 *$ & $-1.11 *$ \\
\hline Good skills & -0.21 & -0.34 & -0.29 \\
\hline \multicolumn{4}{|l|}{ Poor skills (reference group) } \\
\hline \multicolumn{4}{|l|}{ Education } \\
\hline Basic or less & & -1.53 & -1.79 \\
\hline $\begin{array}{l}\text { Vocational or professional } \\
\text { secondary }\end{array}$ & & -0.39 & -0.86 \\
\hline Higher & & 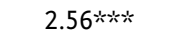 & $2.64 * * *$ \\
\hline \multicolumn{4}{|l|}{$\begin{array}{l}\text { General secondary } \\
\text { (reference group) }\end{array}$} \\
\hline \multicolumn{4}{|l|}{ Language of instruction during studies } \\
\hline Studies in Estonian & & $1.08 * *$ & 0.59 \\
\hline \multicolumn{4}{|l|}{$\begin{array}{l}\text { No studies in Estonian } \\
\text { (reference group) }\end{array}$} \\
\hline \multicolumn{4}{|l|}{ Estonian language writing skills } \\
\hline Very good & & $2.03 * \cdots *$ & $2.59 * * *$ \\
\hline Good & & 0.66 & 0.38 \\
\hline \multicolumn{4}{|l|}{ Moderate or poor (reference group) } \\
\hline \multicolumn{4}{|l|}{ Citizenship } \\
\hline Estonian & & 0.55 & 0.28 \\
\hline \multicolumn{4}{|l|}{ Not Estonian (reference group) } \\
\hline \multicolumn{4}{|l|}{ Region } \\
\hline Tallinn & & & -0.62 \\
\hline \multicolumn{4}{|l|}{ Kohtla-Järve (reference group) } \\
\hline \multicolumn{4}{|l|}{ Branch of industry } \\
\hline $\begin{array}{l}\text { Manufacturing, construction } \\
\text { and transport }\end{array}$ & & & $1.51 *$ \\
\hline $\begin{array}{l}\text { Business service and } \\
\text { social service }\end{array}$ & & & $2.76 * \cdots * *$ \\
\hline \multicolumn{4}{|l|}{ Trade and service } \\
\hline \multicolumn{4}{|l|}{ (reference group) } \\
\hline \multicolumn{4}{|l|}{ Mother tongue of colleagues } \\
\hline Russian & & & -0.54 \\
\hline Mixed & & & -0.07 \\
\hline Estonian (reference group) & & & \\
\hline
\end{tabular}


Table 5.5 continued

\begin{tabular}{lccc}
\hline & $\begin{array}{c}\text { Model with } \\
\text { parental resources }\end{array}$ & $\begin{array}{l}\text { Human } \\
\text { capital model }\end{array}$ & $\begin{array}{l}\text { Structural } \\
\text { model }\end{array}$ \\
\hline Estonian friends & & & -0.17 \\
$\quad$ None & & & -0.81 \\
Few & -1.08 & -2.66 & -3.58 \\
Some (reference group) & 0.11 & 0.43 & 0.50 \\
Constant & & & \\
Pseudo R square & &
\end{tabular}

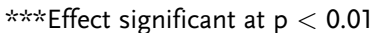

$* *$ Effect significant at $p<0.05$

$*$ Effect significant at $p<0.10$

Source: Own calculations based on TIES

In addition to educational level and Estonian proficiency, the language of instruction during studies also has a positive effect on the probability of getting a higher occupational position. Studying in the Estonian language provides an advantage, even where youth have similar educational levels and Estonian language proficiency. On the other hand, Estonian citizenship does not have any effect on labour market success when other country-specific human capital is taken into account.

The third model includes characteristics that refer to labour market structural constraints and segmentation. It appears that Russians have similar opportunities to achieve higher positions in Tallinn and KohtlaJärve. In line with previous results, it appears that the odds of youth holding a managerial, professional or specialist position depend on the industry they work in. Russians working in business and social services have the best chances of achieving higher occupational status (Appendix 5.I shows that while a similar tendency applies among young Estonians, it seems more profound among Russians). There is no significant effect of mother tongue of colleagues, meaning that Russians in Russian companies are no more successful than Russians in Estonian companies. After adding these ethnic segmentation characteristics into the model, the influence of human capital does not change much, indicating that the importance of language skill and educational level for access to higher occupational position does not depend on city, branch of industry or mother tongue of colleagues. On the other hand, the effect of language of studies reduces, meaning that the importance of this factor might be related to specific labour market segments. The effect of the ethnic structure of friendship networks on access to higher occupational position is also estimated. It appears that having Estonian friends does not give any advantages to Russians in getting higher occupational positions compared to those Russians who have no Estonian friends. Still, this result does not necessarily indicate that ethnically heterogeneous 
networks would not help the second generation in the labour market, because the estimated measure only captures, quite narrowly, friendship networks and not other type of networks, such as connections from school or family.

It seems therefore that Estonian language proficiency and studies in Estonian are the key characteristics that influence the second generation's success in the labour market. In order to explain the significance of these characteristics, additional analysis with Estonian language proficiency and language of studies were carried out, also including Estonians (Table 5.6). It appears that Russians who possess very high Estonian writing skills do not experience any difficulties compared to Estonians of a similar educational level. On the other hand, the Wald test indicates that there are no significant differences between the opportunities of those Russians who have good Estonian writing skills and Russians with moderate or poor Estonian proficiency. Thus, it seems that second-generation Russians with very high Estonian language writing skills do not experience ethnic penalties, while only good language writing skills do not help youth significantly in the labour market. Table 5.6 also shows that Russians who have studied in

Table 5.6 Odds of Estonians and Russians with different language skills and studies achieving managerial, professional and specialist positions, logistic regression models

\begin{tabular}{|c|c|c|}
\hline & $\begin{array}{l}\text { Model with language } \\
\text { proficiency }\end{array}$ & $\begin{array}{l}\text { Model with language } \\
\text { of studies }\end{array}$ \\
\hline \multicolumn{3}{|l|}{ Ethnicity and language } \\
\hline $\begin{array}{l}\text { Russians, very good Estonian writing } \\
\text { skills }\end{array}$ & 0.35 & - \\
\hline Russians, good Estonian writing skills & $-1.07 * * * *$ & - \\
\hline $\begin{array}{l}\text { Russians, poor Estonian writing skills } \\
\text { Estonians (reference group) }\end{array}$ & $-1.32 * * *$ & - \\
\hline \multicolumn{3}{|l|}{ Ethnicity and language of studies } \\
\hline Russians, have studied in Estonian & - & 0.06 \\
\hline $\begin{array}{l}\text { Russians, have never studied in } \\
\text { Estonian } \\
\text { Estonians (reference group) }\end{array}$ & - & $-0.98 * * *$ \\
\hline Constant & -1.44 & -1.35 \\
\hline Pseudo R square & 0.29 & 0.28 \\
\hline $\mathrm{N}$ & 646 & 646 \\
\hline \multicolumn{3}{|c|}{$\begin{array}{l}\text { Note: Gender, age group, parental education, educational level, city, branch of industry and } \\
\text { mother tongue of colleagues are controlled in calculation of these models. } \\
* * * \text { Effect significant at } p<0.01 \\
* * \text { Effect significant at } p<0.05 \\
* \text { Effect significant at } p<0.10 \\
\text { Source: Own calculations based on TIES }\end{array}$} \\
\hline
\end{tabular}


Estonian have similar opportunities to Estonians for achieving higher occupational positions. At the same time, Russians who have never studied in Estonian experience penalties in the labour market, even if they have a similar educational level to Estonians.

\subsection{Conclusion}

Most immigrants arrived in Estonia during the Soviet period, when their movement to Estonia was organised by the labour policy of the Soviet command economy. After Estonia regained its independence in I99I, many of these immigrants confronted a new reality in the labour market. A restructuring of the economy meant that industrial segments occupied by Russians were reorganised and that the demand for labour changed. The new circumstances saw the importance of Estonian-specific human capital increase, a disadvantage for most Russians who lacked this type of capital. Since the beginning of the I990s, the unemployment rate of Russians has been high and they are underrepresented in managerial and professional positions (Statistics Estonia 2009). The results of this analysis reveal that the labour market difficulties experienced by Russians, after societal changes in I99I, continue for the second generation. Although a significant share of second-generation Russians have attained their education in independent Estonia, findings show that they have fewer opportunities to achieve higher occupational positions than Estonian youth. Moreover, it appears that returns from education differ for the second generation and natives. We can conclude, then, that structural integration is still a challenge for the second generation.

Studies in western countries show that parental resources often explain the lower labour market success of the second generation, which means that general processes of social reproduction are significant (Heath 2007). In Estonia, the educational level of parents of the second generation does not differ much from those of the native youth (see Lindemann \& Saar in this volume). However, a direct effect of parental educational level on labour market success was found only for Estonians. One reason why parental resources are not as helpful for Russian youth may be that parents of second-generation Russians experienced more downward mobility after I99I than Estonians, even though their educational level was equal to that of natives. On the other hand, the country-specific human capital of parents does not help young Russians in the labour market, as parents' investment in Estonian language skills does not provide higher chances of labour market success for the second generation. 
That said, other kinds of resources might be important besides education to ensure greater labour market success. One potential explanation is the importance of country-specific human capital. Societal changes brought with them a greater significance of Estonian-specific resources, such as Estonian language skills and citizenship. Results show that investment in country-specific human capital can be crucial for the second generation to achieve higher occupational positions. Members of the second generation with a high level of country-specific human capital fare much better than those with a low level of human capital. Very good Estonian language writing skills significantly raise the probability of labour market success. In addition, Russians who have studied in schools where Estonian is the language of instruction also have an advantage compared to Russians who have never been taught in Estonian. Although there is no direct evidence that the teaching quality in these schools differs, studying in Estonian may contribute to knowledge about the Estonian working environment and provide more connections with ethnic Estonians. On the other hand, the importance of Estonian language writing skills does not depend on city, industry or mother tongue of colleagues, while studies in Estonian are probably more advantageous in specific labour market segments. However, analysis did not show any significant effect of Estonian citizenship for labour market success.

Since the Soviet period, the Estonian labour market has been segmented along ethnic lines. However, the analysis did not indicate that general labour market conditions explain the disadvantage experienced by the second generation. Russians do not have fewer opportunities for achieving high occupational status because they work in economic sectors that are characterised by a smaller number of high-level jobs. It appears that the effect of ethnicity on labour market outcomes is significant even in the case of similar industries. Place of residence has no influence on the significant effect of ethnicity. This indicates that despite differences in labour market structural conditions in Tallinn and Kohtla-Järve, native youth fare much better in both cities compared to the second generation.

Labour market segmentation in Estonia means that there are enterprises where most workers are either Russians or Estonians. However, findings show that working together with Russian colleagues does not explain ethnic differences in the likelihood of attaining a good labour market position. In addition, Russians who work together with other Russians have no advantages in achieving a higher occupational position compared to Russians who work together with Estonians. The specific character of Russian companies in Estonia might be an explanation for this result. Previous research has shown that Russians working in Russian enterprises are often less satisfied with their job and that their 
choice to work there is out of necessity, as a result of their poor Estonian language skills (Helemäe 2008).

One explanation for ethnic minorities' lower labour market integration might be the lack of useful social contacts for promoting their labour market success (Lin 1999; Heath 2007). Previous research in Estonia has pointed out that the separation of social networks along ethnic lines has constrained Russians' labour market opportunities (Luuk $\&$ Pavelson 2002). However, the results of the current analysis show that ethnically more heterogeneous friendship networks do not help the second generation to attain a higher occupational position. Still, it leaves the question open as to whether the ethnic heterogeneity of other networks might be important.

It is presumed that other types of factors, not included in the analysis, may account for the ethnic disadvantage of the second generation. Subjective factors such as motivation and expectations influence labour market behaviour. It has been found that the second generation most likely acquires similar aspirations for economic success as natives (Portes \& Zhou I993). Likewise, there is no reason to expect that young Russians would be less motivated to pursue higher occupational positions. The survey Integration of Estonian Society: Monitoring 2008 shows that expectations about labour market success among young Russians are comparable with the expectations of young Estonians. In addition, Estonian citizenship and good language skills increase the expectations of young Russians (Lindemann \& Saar 2009).

Another possible explanation for second-generation disadvantage might be discrimination by employers. Surveys about integration in Estonian society show that people perceive ethnic inequality in the Estonian labour market. Russians, in particular, perceive many inequalities between the labour market opportunities of ethnic groups (Pavelson 2000; Helemäe 2008). At this point, further research is necessary to detect possible labour market discrimination.

We can conclude that although there are significant differences between the opportunities of the second generation and natives, even when there are similar educational levels, obtaining country-specific human capital, such as very high-level Estonian language writing skills and studying in Estonian, aids the structural incorporation of the second generation. On the other hand, second-generation Russians with only good Estonian writing proficiency lag behind Estonians in labour market competition and their opportunities are comparable to Russians who have low Estonian language skills. It seems therefore that successful labour market integration characterises only those members of the second generation with the highest level of country-specific human capital. 


\section{References}

Alba, R. (2005), 'Bright vs. blurred boundaries: Second-generation assimilation and exclusion in France, Germany and the United States', Ethnic and Racial Studies 28 (I): 20-49.

Andersen, E.A. (1997), 'The legal status of Russians in Estonian privatisation legislation I989-I995, Europe-Asia Studies 49 (2): 303-316.

Bank of Estonia (2008), Annual Indicators of Estonian Economy. www.eestipank.info/pub/ en/dokumendid/statistika/koondtabel. Accessed I December 2008.

Becker, G. (I962), 'Investment in human capital: A theoretical analysis', The Journal of Political Economy 70 (5): 9-49.

Chiswick, B. (I978), 'The effect of Americanization on the earnings of foreign-born men', Journal of Political Economy 86 (5): 897-92I.

Dustmann, C. (1994), 'Speaking fluency, writing fluency and earnings of immigrants', Journal of Population Economics 7 (2): 133-156.

Dustmann, C. \& F. Fabbri (2003), 'Language proficiency and labour market performance of immigrants in the UK', The Economic Journal II3 (489): 695-7I7.

Eamets, R. (I999), 'Estonian labour market and unemployment', Estonian Human Development Report 1999, 66-7I. Tallinn: UNDP.

Eamets, R. (2008), 'Economic structure, labour market and education', Estonian Human Development Report 2007, 97-I02. Tallinn: Eesti Koostöö Kogu.

Esser, H. (2003), 'Does the new immigration require a new theory of intergenerational integration?’ MZES Working Paper No. 7I. Mannheim: MZES.

Estonian Ministry of Education (2008), Uuringud, statistika, andmebaasid. www.hm.ee/index.php?03264 Accessed I5 November 2008.

Friedberg, R. M. (2000), 'You can't take it with you? Immigrant assimilation and the portability of human capital', Journal of Labour Economics I8 (2): 22I-25I.

Granovetter, M. (1985), 'Economic action and social structure: The problem of embeddedness', The American Journal of Sociology 9I (3): 48I-5IO.

Heath, A. (2007), 'Crossnational patterns and processes of ethnic disadvantage', in A. Heath \& S.Y. Cheung (eds.), Unequal chances: Ethnic minorities in western labour market, 639-695. Oxford: Oxford University Academy.

Heath, A. \& S.Y. Cheung (2007), 'The comparative study of ethnic minority disadvantage', in A. Heath \& S.Y. Cheung (eds.), Unequal chances: Ethnic minorities in western labour market, I-44. Oxford: Oxford University Academy.

Helemäe, J. (2008), 'Tööalane eneseteostus ja selle võimaluste tajumine (Self-realisation at work and perceived opportunities for it)', in Integratsiooni monitooring 2008. Aruanne (Integration of Estonian Society, Monitoring 2008. Report). Tallinn: www.rahvastikuminister.ee/?id=I205I. Accessed I December 2008.

Kalter, F. \& I. Kogan (2006), 'Ethnic inequalities at the transition from school to work in Belgium and Spain: Discrimination or self-exclusion?', ScienceDirect, Research in Social Stratification and Mobility 24: 259-274.

Kalter, F., N. Granato \& C. Kristen (2007), 'Disentangling recent trends of the second generation's structural assimilation in Germany', in S. Scherer, R. Pollack, G. Otte \& M. Gangl (eds.), From origin to destination: Trends and mechanisms in social stratification research, 214-245. Frankfurt and New York: Campus.

Kogan, I. (2007), 'Continuing ethnic segmentation in Austria', in A. Heath \& S.Y. Cheung (eds.), Unequal chances: Ethnic minorities in western labour market, I03-I4I. Oxford: Oxford University Academy.

Lauristin, M. \& P. Vihalemm (I997), 'Recent historical developments in Estonia: Three stages of transition (I987-I997)', in M. Lauristin \& P. Vihalemm (eds.), The return to 
the western world: Cultural and political perspectives of Estonian post-communist transition, 73-126. Tartu: Tartu University Press.

Lin, N. (1999), 'Social networks and status attainment', Annual Review of Sociology 25: 467-487.

Lindemann, K. \& E. Saar (2009), 'Non-Estonians in the labour market', Estonian Human Development Report, 95-I00. Tallinn: Eesti Koostöö Kogu.

Luuk, M. \& M. Pavelson (2002), 'Non-Estonians in the labour market: A change in the economic model and differences in social capital', in M. Lauristin \& M. Heidmets (eds.), The challenge of Russian minority, 89-II6. Tartu: Tartu University Press.

Mettam, C.W. \& S. Williams (200I), 'A colonial perspective on population migration in Soviet Estonia', Journal of Ethnic and Migration Studies 27 (I), I33-I5O.

Müller, W. \& M. Gangl (2003), 'The transition from school to work: A European perspective', Transition from Education to Work in Europe, I-2I. Oxford: Oxford University Press.

Nielsen H.S., M. Rosholm, N. Smith \& L. Husted (2003), 'The school-to-work transition for second generation immigrants', Journal of Population Economics I6 (4): 755-786.

Pavelson, M. (2000), 'Sotsiaalmajanduslik integratsioon: tööhõive ja sissetulekud (Socioeconomic integration: employment and incomes)', Integratsioon Eesti ühiskonnas. Monitooring 2000, 22-27. Tallinn: MEIS, TPÜ RASI.

Pettai, V. \& K. Hallik (2002), 'Understanding process of ethnic control: segmentation, dependency and co-operation in post-communist Estonia', Nations and Nationalism 8 (4): 505-529.

Portes, A. \& M. Zhou (I993), 'The new second generation: Segmented assimilation and its variants', The ANNALS of the American Academy of Political and Social Science 530 (74): $74-96$.

Portes, A. (I995), 'Economic sociology and the sociology of immigration: A conceptual overview', in A. Portes (ed.), The economic sociology of immigration: Essays on networks, ethnicity and entrepreneurship, I-4I. New York: Russell Sage Foundation.

Portes, A., P. Fernandez-Kelley \& W. Haller (2005), 'Segmented assimilation from the ground: The new second generation in early adulthood', Ethnic and Racial Studies 28 (6): 1000-1040.

Statistics Estonia (2009), Statistical database. www.stat.ee. Accessed I February 2009.

Statistical Yearbook of Tallinn 2007 (2008), Tallinn: Tallinn City Government www.tallinn. ee/est/g2677\$40985. Accessed I June 2008.

Vihalemm, T. (2008), 'Keeleoskus ja hoiakud (Language proficiency and attitudes)', in Integratsiooni monitooring 2008. Aruanne (Integration of Estonian Society, Monitoring 2008. Report). www.rahvastikuminister.ee/?id=I205I. Accessed I December 2008.

Vöörmann, R. \& J. Helemäe (2003), 'Ethnic relations in Estonia's post-Soviet business community', Ethnicities 3 (4): 509-530. 
Appendix 5.1 Access to managerial, professional and specialist positions, separate logistic regression models for Estonians and Russians

\begin{tabular}{|c|c|c|}
\hline & Estonians & Russians \\
\hline \multicolumn{3}{|l|}{ Gender } \\
\hline Men & -0.10 & 0.71 \\
\hline \multicolumn{3}{|l|}{ Women (reference group) } \\
\hline \multicolumn{3}{|l|}{ Age group } \\
\hline $18-25$ & $-0.86 * * * *$ & $-0.95 * *$ \\
\hline \multicolumn{3}{|l|}{ 26-35 (reference group) } \\
\hline \multicolumn{3}{|l|}{ Parental education } \\
\hline Higher & $0.57 *$ & 0.51 \\
\hline \multicolumn{3}{|l|}{ Lower (reference group) } \\
\hline \multicolumn{3}{|l|}{ Education } \\
\hline Basic or less & -0.68 & $-1.92 *$ \\
\hline Vocation or professional secondary & -0.27 & -0.76 \\
\hline Higher & $1.20 * * * *$ & $2.30 * \cdots *$ \\
\hline \multicolumn{3}{|l|}{ General secondary (reference group) } \\
\hline \multicolumn{3}{|l|}{ Region } \\
\hline Tallinn & 0.02 & -0.07 \\
\hline \multicolumn{3}{|l|}{ Kohtla-Järve (reference group) } \\
\hline \multicolumn{3}{|l|}{ Branch of industry } \\
\hline Manufacturing, construction and transport & 0.42 & 1.09 \\
\hline Business service and social service & $1.17 * 2 *$ & $2.27 * \cdots * k$ \\
\hline \multicolumn{3}{|l|}{ Trade and service (reference group) } \\
\hline \multicolumn{3}{|l|}{ Mother tongue of colleagues } \\
\hline Russian & 0.09 & -0.67 \\
\hline Mixed & -0.12 & -0.41 \\
\hline \multicolumn{3}{|l|}{ Estonian (reference group) } \\
\hline Constant & -1.17 & -2.62 \\
\hline Pseudo R square & 0.19 & 0.40 \\
\hline $\mathrm{N}$ & 345 & 301 \\
\hline
\end{tabular}

Source: Own calculations based on TIES 


\title{
6 Income inequality
}

\author{
Rein Vöörmann and Jelena Helemäe
}

\subsection{Introduction}

Income refers to a consumption opportunity gained by an entity within a specified time frame, which is generally expressed in monetary terms (Barr 2004). However, for households and individuals 'income is the sum of all the wages, salaries, profits, interests payments, rents and other forms of earnings received in a given period of time' (Case \& Fair 2000).

In this chapter we focus not so much on consumption opportunity but rather, on the importance and amount of income from employment, as well as on the probability of belonging to a highly paid group of employees. Income inequality is of particular importance for at least two reasons: I) it is the indication of labour market success or failure; 2) it is an important economic resource that (to a great extent) determines the living conditions of the individual and/or his household. The first approach focuses on the factors of individual labour market behaviour. The second approach takes into account the income generating capabilities of the household as a whole, given the assumption that these capabilities determine the resources and welfare available to the individual. In this chapter, we focus on the first approach.

Ethnic inequality in income is a frequently documented phenomenon in many developed countries (see e.g. Borjas 1985, I995; Chiswick \& Miller I995; Husted, Nielsen, Rosholm \& Smith 200I; Nielsen, Rosholm, Smith \& Husted 2004; Black, Haviland, Sanders \& Taylor 2006; Inglis \& Model 2007; Tesser \& Dronkers 2007; Hammarstedt 2009). Some researchers have found that immigrants in Western Europe earn around 40 per cent less at arrival than natives born in that destination (Adsera \& Chiswick 2007). According to others, the difference is smaller (and depends, in turn, on gender; Antecol, Cobb-Clark \& Trejo 2003; Treiman 2007) and usually diminishes with time since migration (Chiswick 1978; Baker \& Benjamin 1994; Schoeni 1997; Friedberg 2000).

Different factors are used to explain the disadvantage of immigrants. Some explanations stress the role of a lower level of human capital, meaning educational attainment (Becker 1964; Mincer 1974); others 
focus on country-specific human capital, meaning, primarily, the language proficiency of the immigrant population (Chiswick 1978). A third group of explanations relate to structural factors and ethnic segmentation across industries (Kalleberg \& Berg 1987; Le Grand, Szulkin \& Thalin 1994). However, previous research has shown that even if we include all the relevant information we have, immigrants are still paid less. The most frequent conclusion is that there is ethnic discrimination, which, indeed, is supported by the results of a number of studies (Bovenkerk, Gras \& Ramsoedh I995; Kroncke \& Smith 1999).

At the same time, much less is known about the second generation of immigrants. Do they also earn less compared to the native population? Unfortunately, according to Crul and Vermeulen (2003), research on the second generation of post-war immigrants is a relatively new phenomenon. The second generation has only become a central focus in the studies of immigrant populations in the past decade. However, the second generation can be expected to fare somewhat better than the first, albeit often remaining at an overall disadvantage. The problem is that the ethnic hierarchy established in the first generation might be continued in the second generation (Heath \& Cheung 2007).

In Estonia, the second generation of immigrants has also received little attention, and income disparity is seldom studied. There are studies concerning the immigrants' position in the Estonian labour market as a whole (Kroncke \& Smith 1999; Pavelson 2002), but not that of the second generation. Moreover, the concept of second generation is hardly used either in public or in scientific debate, while issues of 'nonEstonian youth' are approached instead. This is why there are almost no studies concerned with the question of income from the comparative point of view - between the second-generation Russians and their Estonian counterparts.

The main goals of this chapter are: first, to study whether or not second-generation Russians and their Estonian counterparts have similar access to employment and, consequently, the opportunities to earn wages; second, to assess the magnitude of ethnic inequality in income from employment; and third, to explore the extent to which the chances of belonging to the highly paid segment of youth can be accounted for by the differences in human capital and different returns on it.

\subsection{Theoretical approaches}

The explanations usually offered for the earnings gap between secondgeneration immigrants and natives are, just as in the case of other labour market outcomes, the (general) human capital and country-specific human capital approaches at the individual level and the segmentation 
of the labour market argument at the macro level. As these approaches have been introduced in previous chapters, we will only briefly review them here.

\subsubsection{Human capital approach}

According to a traditional human capital approach (Becker I964; Mincer I974), the differences in rewards are adequately explained by individual characteristics. As workers differ from each other in ability, skills, experience and other individual properties that influence their productive capacity, it is understandable, in every respect, that the level of individual rewards is that better educated people earn more and returns to the less well-educated are lower. Indeed, in most Western countries differences in the educational level between ethnic groups is evident (Heath \& Brinbaum 2007), which, in turn, determines the level of individual rewards. In short, and more precisely, according to this approach, the lower wage rate of immigrants is legitimate and explained by their lower productivity. At the same time, there are a number of theoretical reasons to suggest that for those second-generation immigrants who have domestic qualifications a) human capital operates in the same way as it does for the native population and b) the second generation obtains the same returns on their qualifications as the native population does (Heath \& Cheung 2007).

However, this narrowly individualistic perspective has been criticised for neglecting the impact of structural factors on stratification and inequality.

\subsubsection{Country-specific human capital}

In order to distinguish between domestic and foreign sources of human capital, i.e. whether the skills and competences have been acquired in the country of origin or in the country of destination, the concept of 'country-specific' human capital is used (Chiswick I978). The implication of this term is that the gap between what is endowed on immigrants and natives by this capital should decrease the longer the immigrants stay in the country of destination: they gradually acquire countryspecific skills by learning the language, accumulating labour market experience, etc. The expectation is that this then leads to a contraction of the earnings gap between natives and immigrants. Thus, one should not expect country-specific capital to be the reason why second-generation immigrants are disadvantaged (in terms of earnings) compared with their native counterparts. 


\subsubsection{Structural approach}

The central thesis of the structural perspective is that individuals with similar productive capacities are often rewarded differently because the structural setting within which individuals work, varies significantly. This setting consists of three components: I) the position or job which the individual occupies, 2) the organisation where the job is located and 3) the wider context of the organisation, such as the national labour market (Kalleberg \& Berg I987; Le Grand et al. I994). The crossnational patterns of second-generation immigrants' labour market disadvantage have been explained - in addition to the general nature of the economy and labour market - also by the general processes of social reproduction and, specifically, those that focus on ethnic-related phenomena such as discrimination and xenophobia, the conception of the nation and access to citizenship (Heath 2007).

\subsection{Estonian context}

First, let us examine the question of the division of the Estonian economy, given that according to a structural approach, differences in earnings might be the outcome of such division.

During Soviet times, the Estonian economy was divided into a socalled 'all-union' segment and a 'local' segment. The 'all-union' segment was mainly formed from the Soviet military industry complex and was ruled from the centre - Moscow. It largely depended on the centre in terms of the supply of raw materials and labour, and its production was utilised outside Estonia (Aasland I997; Hallik I998). The 'local' segment of the Estonian economy was governed by Estonian ministries, the production from this segment was used within Estonia and its employees were mainly Estonians. Because the Soviet leadership prioritised the military industry, workers in the all-union segment were economically advantaged in terms of both higher wages and better access to consumer goods. Furthermore, because the all-union segment employed mainly Russians, their economic conditions were more favourable than those of the Estonians.

With the restoration of the Estonian state, the Estonian economy 'turned to the West' and the all-union segment of the economy lost access to both raw materials and markets, resulting in a decrease in the role of the manufacturing industry in Estonia. This situation brought about both economic and social consequences for the parents of second-generation Russians - the demand for Russian labour diminished as their economic basis faded away (Pavelson 2000). 
The social networks of those employed in the 'all-union' segment were largely working-collective-centred and so the Russian social networks in newly independent Estonia turned out to be poorly placed in terms of helping workers to find jobs or in creating 'ethnic entrepreneurship’ (Vöörmann \& Helemäe 2003). These economic consequences of market reforms coincided with the overall transformation of the status of Russians from that of local representatives of an imperial ethnic group to one of a minority in a small nation state (Anderson, Silver, Titma \& Ponarin 1996). Thus, Russians experienced severe consequences because of the transition, such as unemployment, higher downward mobility, etc.

While the post-Soviet restructuring of the Estonian economy brought about a higher unemployment rate among non-Estonians (the majority of whom were Russian) as compared to Estonians (see Figure 6.I) with an especially big gap between the younger age groups, the economic growth of the beginning of the century was not followed by a narrowing of the ethnic gap (Helemäe 2008).

Figure 6.1 Employment and unemployment rates of Estonians and non-Estonians, 1997-2008 (in \%)

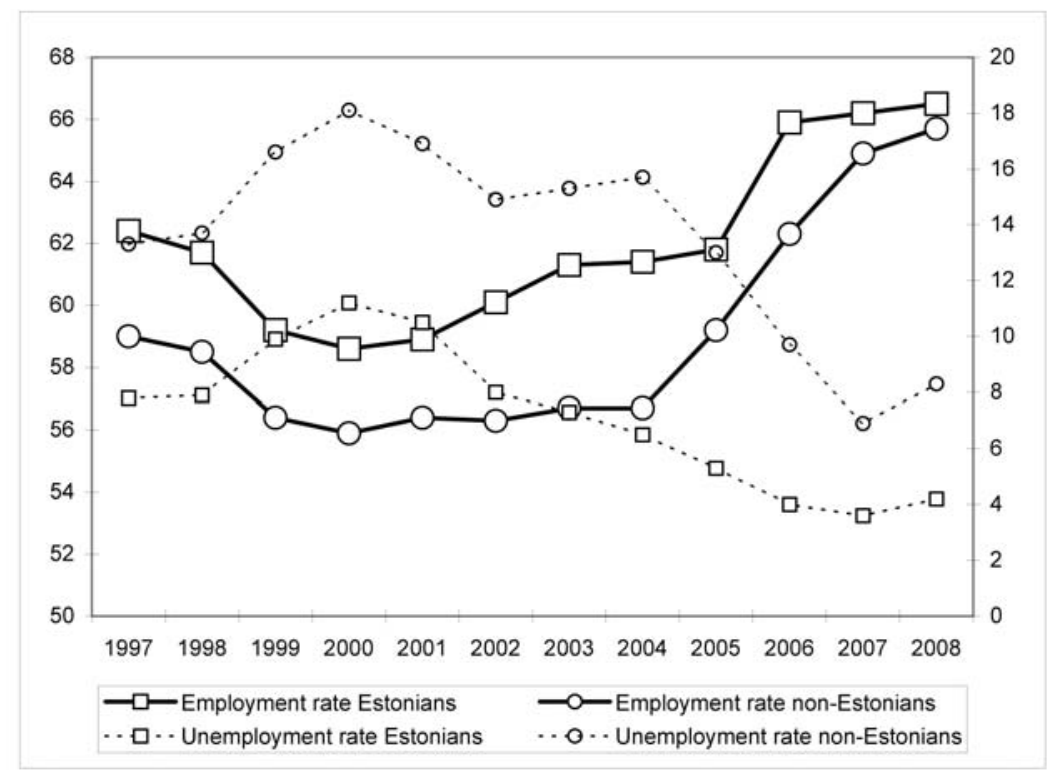

Source: Statistics Estonia 
At the time of our survey, the employment status of both very young and prime-age Russians was rather disadvantaged compared to that of Estonians (see Figure 6.2).

All this had a certain influence on the income differences between ethnic groups. According to Kairi Kasearu and Avo Trumm (2008), the income of the Russian-speaking population was significantly (12-20 per cent) lower compared to that of Estonians during the period of 19942006. Moreover, results of the analyses of different authors reveal significant ethnic differences in income from employment (Noorkõiv, Orazem, Puur \& Vodopivec I998; Kroncke \& Smith I999; Anspal 2008; Leping \& Toomet 2008). The overall conclusion is that differences in wages are a post-Soviet phenomenon in Estonia. The analysis by Leping and Toomet (2008) is based on Estonian Labour Force Survey data and is restricted to males only. It shows that before the restoration of independence, on average, Russian workers earned more (see gross differential in Figure 6.3). It also shows that this differential worked in their favour, in the sense that this differential persists even after taking into account such factors as differences in age, education, family status, immigrant origin, region, language, industry and occupa-

Figure 6.2 Population according to employment status, by gender and age group, 2006 (in \%)

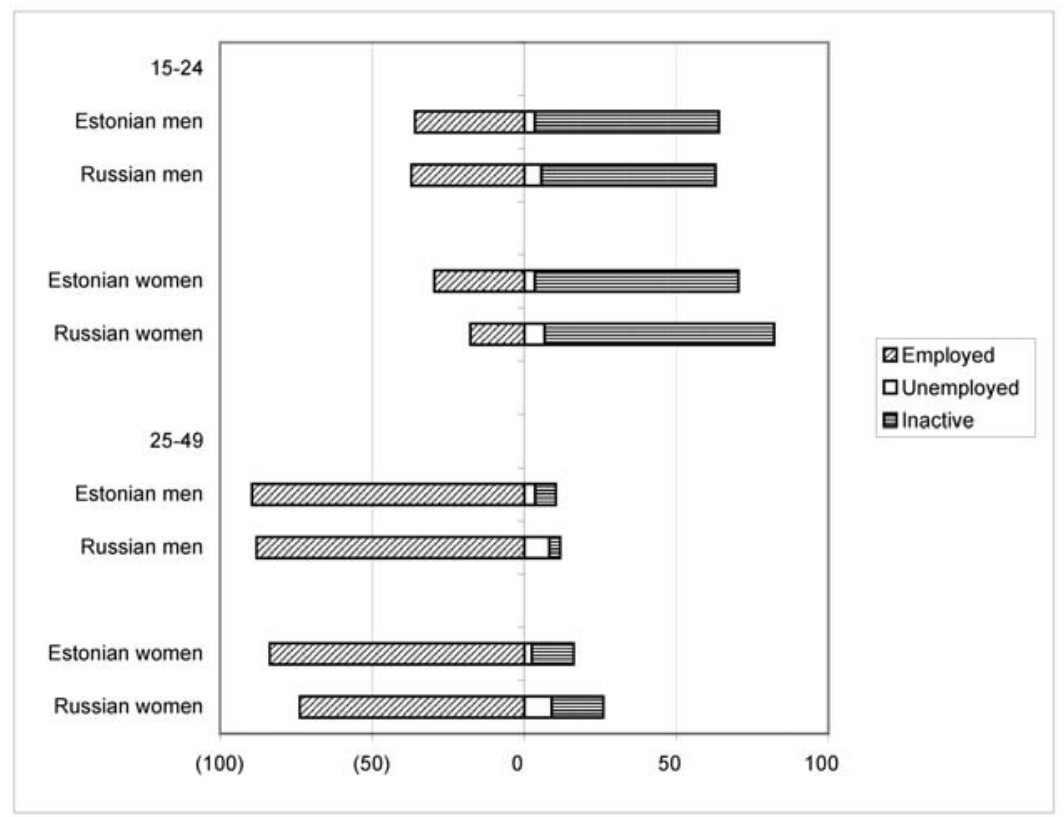

Source: Statistics Estonia 
tion (see Unexplained differential in Figure 6.3). However, the authors have documented a substantial rise in the unexplained wage gap between ethnic groups since the restoration of independence: '...the gap increased thereafter and reached around IO-I5 per cent of the average wage in favour of the Estonian-speaking workers' (Leping \& Toomet 2008). Although this difference started to decrease from the middle of this decade, it still exists (see Figure 6.3).

Charles Kroncke and Kenneth Smith (I999) came to a similar conclusion while attempting to examine potential wage discrimination based on ethnicity. Using ELFS data and looking at male full-time workers in the years 1989 and I994, the authors discovered that there was no evidence of discrimination against either group in i989. At the same time, the available data provided substantial evidence of discrimination against ethnic Russians in the Estonian labour market in I994: considering the characteristics of ethnic groups, the potential wage differential would have been Iı.6 per cent in favour of the Russians, while in reality it was 5.2 per cent in favour of Estonians.

Marje Pavelson (2002), relying on monitoring data from Integration in Estonian Society 2002, has declared that income across the ethnic groups does not differ on the lowest end of the scale, but does pose a problem on the upper end of the scale. There are significantly more Estonians among the higher income group, although their proportion in the core Estonian group is actually negligible.

A similar conclusion can be drawn from the data of Statistics Estonia (Kasearu \& Trumm 2008). In addition, the results of the European Social Survey (2006) demonstrate that Estonians are much more fre-

Figure 6.3 Gross and unexplained wage differential in favour of ethnic Russians compared with Estonians (in \%)

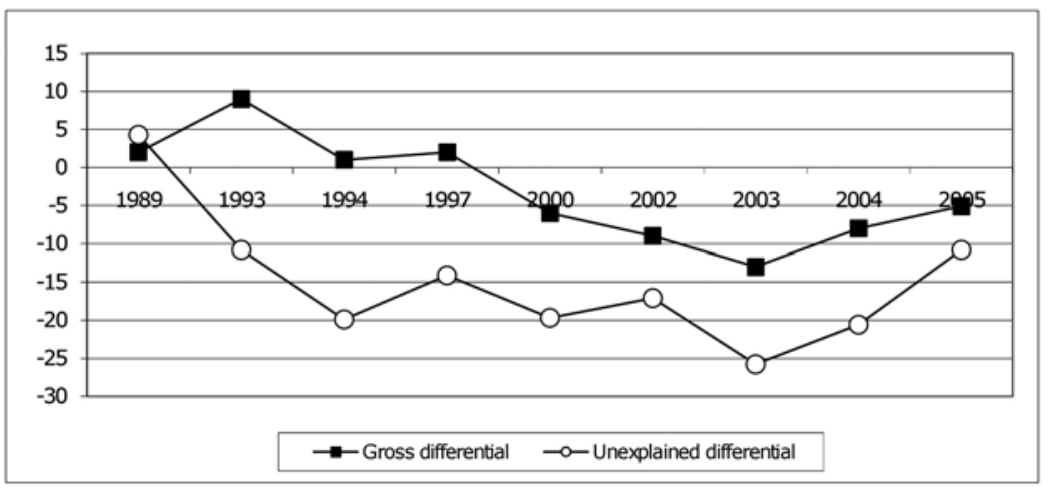

Source: Data presented by Leping and Toomet (2008: 604, Table 2) 
quently represented in the top income quintile than non-Estonians (see Figure 6.4). This is why ethnic differences in the access to the higherearners group are of particular interest.

At the same time, some researchers argue that numerous analyses of poverty, income and living conditions have revealed a similar level of material resources among Estonians and non-Estonians. Furthermore, they support the idea that non-Estonians are not significantly poorer in terms of income and the statements about discrimination of minorities are more or less social and political myths (Trumm 2005).

Our focus will be, primarily, on the ethnic differences in income from employment. We will explore differences both in the importance of employment as the source of income, as well as in the amount of income from employment. We pay special attention to access to the segment of higher earners and the significance of country-specific human capital as a factor of that access. We suggest that the labour market situation of second-generation Russians, as compared to their Estonian counterparts, is determined not so much by their 'non-nativity', in terms of being born into a family of first-generation immigrants but rather, by their belonging to the ethnic group of Russians. Thus, we expect that they face the same kind of disadvantage as was described above for all Russians and/or the Russian-speaking population that makes up the majority of non-Estonians. In other words, we suggest

Figure 6.4 Distribution of Estonian and non-Estonian population by income quintiles, 2006 (in \%)

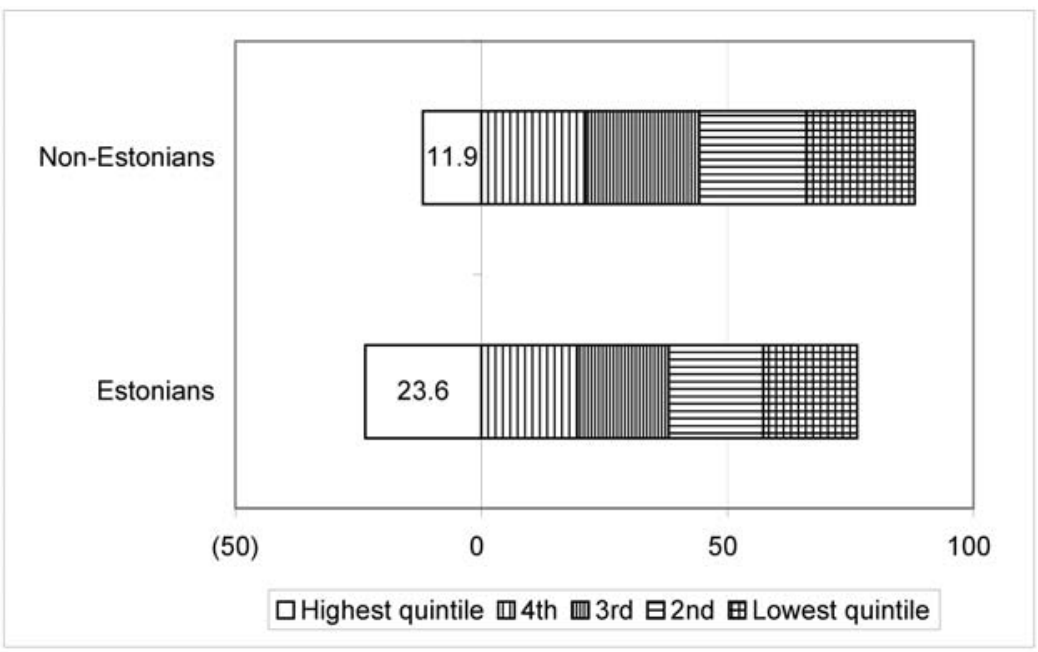

Source: Statistics Estonia 
that the proportion of second-generation Russians receiving an income from employment is lower compared to Estonians. They also receive a lower amount of income from employment compared to Estonians. Given the lower occupational status of second-generation Russians, as compared to Estonians (see Lindemann in this volume), we expect them to have a lower probability of belonging to the group of highly paid earners, and this is even the case for those with a similar level of human capital. In terms of the importance of country-specific human capital, our points of departure are that: a) the majority of Russian youth go through educational institutions with Russian as the primary language of instruction; b) the Estonian language proficiency of young Russians depends not so much on the fact that they were born in Estonia, as on the quality of Estonian teaching in schools operating in Russian; c) the quality of Estonian teaching had been improving slowly compared to the raising of requirements in the level of knowledge of Estonian; d) that the role of parents in investing in Estonian language proficiency is very important (see Lindemann in this volume); e) that acquisition of Estonian citizenship is highly dependent on Estonian language proficiency; f) that Estonian citizenship is important for gaining jobs not only in the civil service but also in a number of high-status and highly paid jobs. This is why, contrary to the standard predictions, we also expect country-specific capital to have a significant impact on the probability of second-generation Russians belonging to the group of highly paid earners.

\subsection{Variables and methods}

We depart from the assumption that income from employment has a different importance at different stages of the life course. Income is of greatest importance for those who have left both the education system and the parental family and especially for those with their own household. This is why in order to study the importance of employment as a source of income we use the data on the employment status of respondents to differentiate, first of all, between those who left (non-studying youth) versus those who are still in the education system (studying youth). Secondly, for those who do not study, we make a distinction between those who work and those who do not work. To characterise the net monthly income from employment of employed non-studying youth, data measured by an interval scale from a questionnaire are used. Table 6.3 presents the entire scale.

To differentiate between the different stages of life course related to family formation, we make a distinction between those living alone, those who have a partner and/or child and are saying that they or their 
partner are head of the household, and those who live with their parents or grandparents and say that parents or grandparents are heads of household (see Table 6.2).

To reveal how ethnicity and other characteristics influence the probabilities of access to the highly paid income group compared to the probability of belonging to the low-paid income group, a logistic regression analysis was carried out.

Belonging to the highly paid income group is defined as receiving at least 7,000 EEK or $€ 450$ per month from employment.

Ethnicity is the main independent variable. Ethnicity is measured as self-estimation and shows whether the respondent belongs to the group of second-generation Russians or native Estonians.

Other important independent demographic variables are gender and age group. Respondents are divided into two age groups: those I8-25 years old and those 26-35 years old.

The highest level of the parents' education characterises the respondent's socio-economic background. We distinguish between two levels of parental education: I) lower than higher education and 2) higher education. We use the same scale to measure the human capital of respondents (the highest educational level attained at the time of survey).

In order to measure the structural conditions of the labour market and its ethnic segmentation, the following variables are included: region (Tallinn versus Kohtla-Järve and Jõhvi. For a description of the respective local labour markets, see Lindemann in this volume); the characteristics of the current job of the respondent: branch of industry (depending on the representation of Russian employees - whether they are overrepresented, represented to the same extent as Estonians or underrepresented); sector of economy (private versus public); mother tongue of colleagues at work (whether the same as that of respondent) and ethnicity of supervisor (whether it is the same as that of respondent). Bridging social ties are measured based on the ethnicity of friends (whether respondents have some friends in an ethnic community that is different from their own). Bonding social ties are measured as having relatives in a given city.

\subsection{Results}

\subsubsection{Importance of income from employment}

Most of the people under consideration have some sort of independent income through employment, social benefits or a partner's employment/social benefits, or at least parental (including partner's parents) support. We are primarily concerned with the most common source of income - income from employment. Figure 6.5 presents the employment status of second-generation Russians and Estonians. 
Figure 6.5 Current employment status by ethnicity and age (in \%)

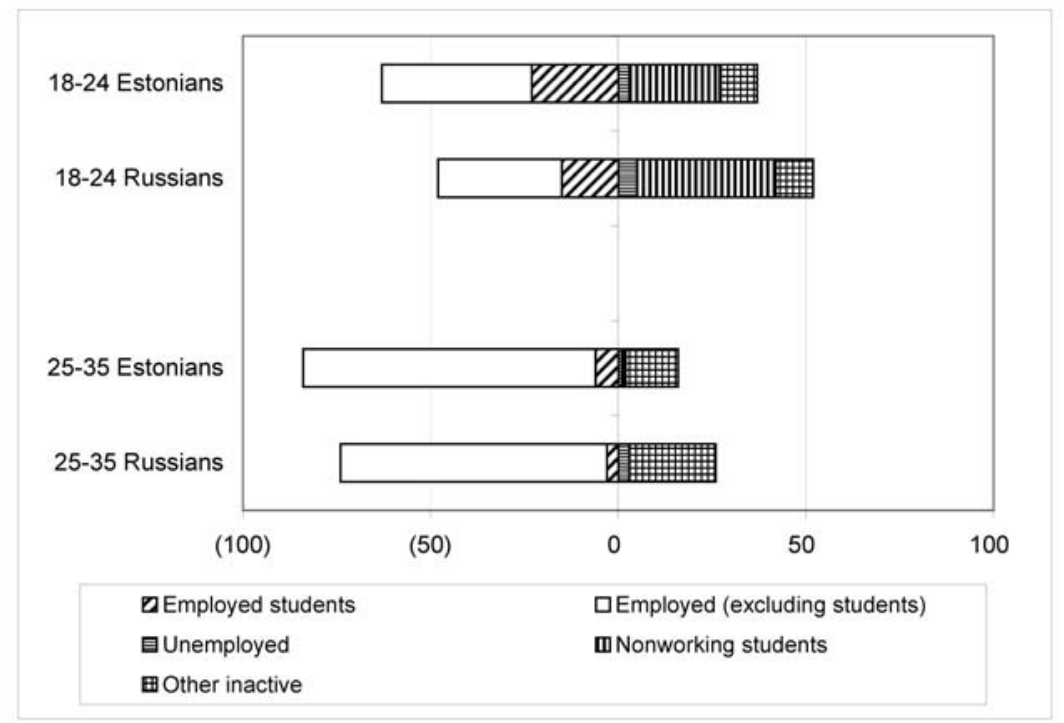

Source: Own calculations based on TIES

According to survey data, there are more employed Estonians compared to Russians in both age groups. In terms of the younger age group, there are important differences related to the employment of students: Estonian students are more often employed than Russian students are. In respect to the older age group, the share of inactive persons is higher among Russians. This is due to the higher percentage of Russian women who are housewives or on parental leave compared to Estonian women.

Table 6.I provides evidence in favour of our basic assumption that the importance of employment as a source of income depends on the stage of life course, which is more important for those who have left the education system (see Total rows). As expected for both age groups, and most importantly for the group aged 26-35, employment is a more available source of income for Estonians than for Russians.

Regarding the impact of the parents and family on the employment status of youth, it appears that the parents' employment exerts indirect influence on the employment of youngsters. Parents' employment influences more the opportunity to participate in studies: the offspring of families with both parents employed can afford to continue studies longer than those who have unemployed parents. This holds true for both ethnic groups and, above all, for the younger age group. In terms of this younger age group, the share of those neither studying nor 
Table 6.1 Employment and studies by parents' employment, ethnicity and age (in \%)

\begin{tabular}{|c|c|c|c|c|c|c|}
\hline \multirow{2}{*}{$\begin{array}{l}\text { Ethnic and } \\
\text { age groups }\end{array}$} & \multirow{2}{*}{$\begin{array}{l}\text { Parents employment: } \\
\text { Who is employed? }\end{array}$} & \multirow[t]{2}{*}{ Studies } & \multirow[t]{2}{*}{ Employment } & \multirow{2}{*}{$\begin{array}{l}\text { Neither studies } \\
\text { nor employment }\end{array}$} & \multicolumn{2}{|c|}{ Total } \\
\hline & & & & & $\%$ & $N$ \\
\hline \multirow[t]{4}{*}{$\begin{array}{l}\text { Russians } \\
15-25\end{array}$} & $\begin{array}{l}\text { Neither father } \\
\text { nor mother }\end{array}$ & 29 & 46 & 25 & 100 & 24 \\
\hline & One parent & 43 & 33 & 24 & 100 & 82 \\
\hline & Both parents & 58 & 29 & 13 & 100 & 169 \\
\hline & Total & 51 & 32 & 17 & 100 & 275 \\
\hline \multirow[t]{4}{*}{$\begin{array}{l}\text { Russians } \\
26-35\end{array}$} & $\begin{array}{l}\text { Neither father } \\
\text { nor mother }\end{array}$ & 6 & 70 & 24 & 100 & 71 \\
\hline & One parent & 0 & 68 & 32 & 100 & 81 \\
\hline & Both parents & 5 & 73 & 22 & 100 & 85 \\
\hline & Total & 3 & 71 & 26 & 100 & 237 \\
\hline \multirow[t]{4}{*}{$\begin{array}{l}\text { Estonians } \\
15-25\end{array}$} & $\begin{array}{l}\text { Neither father } \\
\text { nor mother }\end{array}$ & 27 & 60 & 13 & 100 & 15 \\
\hline & One parent & 43 & 43 & 14 & 100 & 63 \\
\hline & Both parents & 50 & 37 & 13 & 100 & 150 \\
\hline & Total & 47 & 40 & 13 & 100 & 228 \\
\hline \multirow[t]{4}{*}{$\begin{array}{l}\text { Estonians } \\
26-35\end{array}$} & $\begin{array}{l}\text { Neither father } \\
\text { nor mother }\end{array}$ & 2 & 82 & 16 & 100 & 76 \\
\hline & One parent & 7 & 77 & 16 & 100 & 92 \\
\hline & Both parents & 11 & 74 & 15 & 100 & 92 \\
\hline & Total & 7 & 77 & 16 & 100 & 260 \\
\hline
\end{tabular}

Source: Own calculations based on TIES

working among all Estonians is similar to that of those Russians whose parents are both employed. However, this share is significantly higher for Russians who do not have two employed parents. This indicates the emergence of intergenerational transmission of disadvantage among some groups of Russians and offers one explanation as to why the share of the second-generation Russians engaged in paid work is lower compared to natives.

To take more into account the life stage peculiarities of the non-studying respondents, we distinguish between them according to their living arrangements, i.e. their marital status and their relations with the parental family. Table 6.2 and Figure 6.6 show who is responsible for the income provision for those young Russians and Estonians who have left educational institutions - whether it is the youth themselves (having income from employment), the state (through benefits) and/or their parents. Evidently, for all kinds of distinctive living arrangements, Estonians have a somewhat higher share of young people who have income from employment, while Russians rely, to a greater extent, on the state and/or their parents' support (Table 6.2). Altogether, the patterns 
Table 6.2 Non-studying respondents' employment, benefits and parental support as sources of income by living arrangement and ethnicity (in \%)

\begin{tabular}{|c|c|c|c|c|c|c|c|c|}
\hline & \multicolumn{2}{|c|}{ All respondents } & \multicolumn{2}{|c|}{$\begin{array}{l}\text { Own household } \\
\text { with partner } \\
\text { and/or child**** }\end{array}$} & \multicolumn{2}{|c|}{$\begin{array}{l}\text { Single-person } \\
\text { household }\end{array}$} & \multicolumn{2}{|c|}{$\begin{array}{l}\text { In parental/ } \\
\text { grandparental } \\
\text { household }\end{array}$} \\
\hline & $E^{*}$ & $R * *$ & $E$ & $R$ & $E$ & $R$ & $E$ & $R$ \\
\hline Total & 100 & 100 & 100 & 100 & 100 & 100 & 100 & 100 \\
\hline $\begin{array}{l}\text { Has income from } \\
\text { employment }\end{array}$ & 80 & 70 & 78 & 69 & 93 & 89 & 81 & 64 \\
\hline $\begin{array}{l}\text { Has no income from } \\
\text { employment but }\end{array}$ & 20 & 30 & 22 & 31 & 7 & 11 & 19 & 36 \\
\hline $\begin{array}{c}\text { - receives benefits and } \\
\text { money from parents }\end{array}$ & 4 & 12 & 4 & 12 & 0 & 0 & 7 & 16 \\
\hline $\begin{array}{l}\text { - receives benefits } \\
\text { (no money from } \\
\text { parents) }\end{array}$ & 11 & 12 & 16 & 14 & 0 & 4 & 0 & 6 \\
\hline $\begin{array}{l}\text { - receives money from } \\
\text { parents (no benefits) }\end{array}$ & 2 & 4 & 0 & 2 & 2 & 7 & 9 & 10 \\
\hline
\end{tabular}

$* * *$ Those who described self or partner as head of household

** Russians

*Estonians

Source: Own calculations based on TIES

Figure 6.6 Structure of income sources of respondents' own household by ethnicity (in \%)

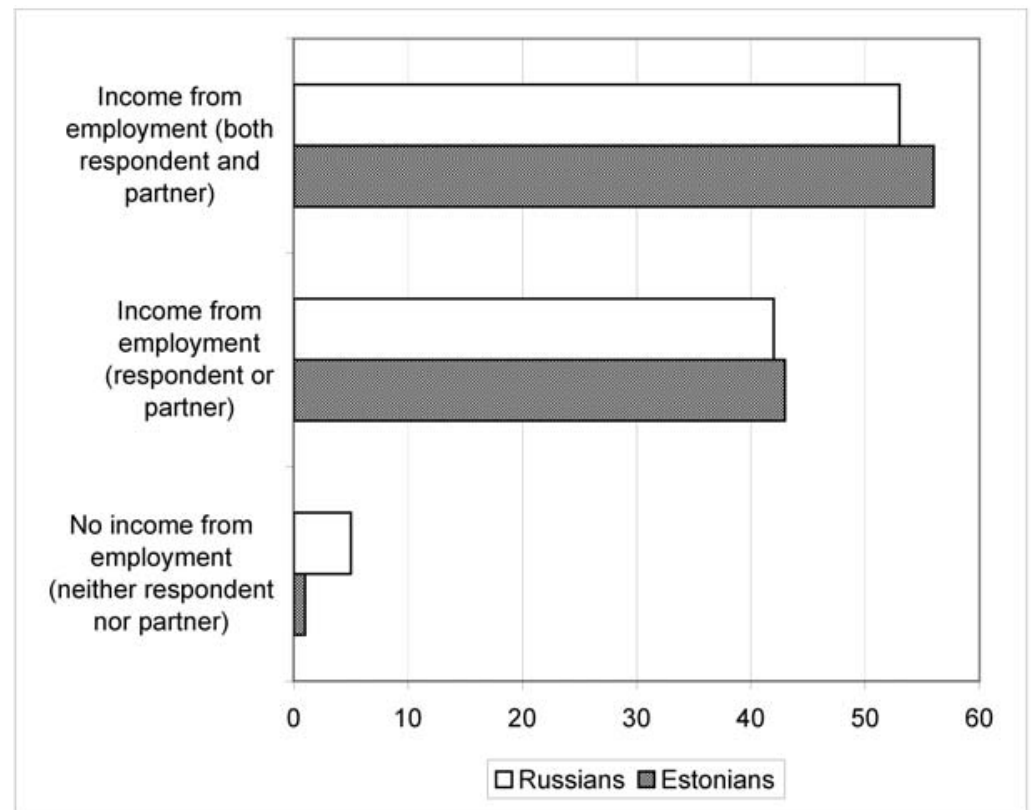

Source: Own calculations based on TIES 
are quite similar: the majority of youth have income from employment, while the share of those supported by the state only is rather low. For those living in parental households, the parents are an important source of support. Within both ethnic groups, there are no significant differences in employment between those living with partners and/or children versus those living in parental households. Youngsters in singleperson households have the highest employment rate. As to independent households, when the partner's employment is taken into account (Figure 6.6), nearly all Russian and Estonian households have income from employment.

\subsubsection{Amount of income from employment}

Of greater interest than the issue of income received from work is information on the monthly amount of Estonian kroons (EEK) the respondents earned. Table 6.3 gives an overall picture across the four groups: Russian men and women and Estonian men and women. Since a high percentage of respondents did not report the amount of income received and in particular Russian women, two distributions of reported income are presented: a) all non-studying employed respondents and b) only those among them who reported their income. The first and most general conclusion is that Estonians tend to earn more than secondgeneration Russians. This holds true for both men and women and for both abovementioned types of measurement. For men, ethnic difference is most clear at the highest levels of the wage hierarchy: only 26 per cent of Russian men receive more than I0,000 EEK per month, while among Estonians the relative share is 43 per cent. For women, ethnic differences reveal themselves at both poles of the wage scale, but more clearly at the lowest one: 40 per cent of Russian women earn less than 5,000 EEK per month, compared to 26 per cent of Estonian women. All this undoubtedly indicates some sort of ethnic inequality in the Estonian society.

The second striking feature concerns the gender wage gap, especially among Russians and to a lesser extent among Estonians as well. The gender wage gap is a well-documented phenomenon all over the world (see e.g. Rosenfeld \& Kalleberg I990; Reskin \& Padavic I994; Jurajda 2003; Huffman 2004; De la Rica 2008) and the same pertains to Estonia (Orazem \& Vodopivec 2000; Vöörmann 2000; Rõõm \& Kallaste 2004). Moreover, previous research has shown that the gender wage gap in Estonia is among the highest in Europe (Randoja 2008). This statement is supported by comparative data of the second-generation Russians and their Estonian counterparts, again evidencing the disadvantage of women. While only every twentieth Estonian man received income from employment of less than 5,000 EEK per month, the same 
Table 6.3 Monthly income of non-studying youth by ethnic group and gender (in \%)

\begin{tabular}{|c|c|c|c|c|c|c|c|c|}
\hline & \multicolumn{4}{|c|}{ Russians } & \multicolumn{4}{|c|}{ Estonians } \\
\hline & \multicolumn{2}{|c|}{ Male } & \multicolumn{2}{|c|}{ Female } & \multicolumn{2}{|c|}{ Male } & \multicolumn{2}{|c|}{ Female } \\
\hline & All & $\begin{array}{l}\text { Those } \\
\text { reporting } \\
\text { income }\end{array}$ & All & $\begin{array}{l}\text { Those } \\
\text { reporting } \\
\text { income }\end{array}$ & All & $\begin{array}{l}\text { Those } \\
\text { reporting } \\
\text { income }\end{array}$ & All & $\begin{array}{c}\text { Those } \\
\text { reporting } \\
\text { income }\end{array}$ \\
\hline Less than 2,000 EEK & 2 & 2 & 1 & 2 & 1 & 1 & 2 & 0 \\
\hline $2,001-3,500$ EEK & 4 & 5 & 12 & 16 & 1 & 1 & 7 & 8 \\
\hline $3,501-5,000$ EEK & 9 & 10 & 27 & 35 & 3 & 4 & 17 & 20 \\
\hline $5,001-7,000$ EEK & 18 & 20 & 24 & 30 & 14 & 16 & 24 & 29 \\
\hline 7,001 - 10,000 EEK & 29 & 33 & 8 & 10 & 26 & 30 & 20 & 23 \\
\hline $1,0001-15,000$ EEK & 14 & 16 & 3 & 4 & 25 & 28 & 13 & 16 \\
\hline $\begin{array}{l}\text { More than } \\
15,000 \text { EEK }\end{array}$ & 12 & 14 & 2 & 3 & 18 & 20 & 4 & 4 \\
\hline $\begin{array}{l}\text { Refuses to answer } \\
\text { question }\end{array}$ & 9 & & 8 & & 10 & & 10 & \\
\hline Don't know & 3 & & 15 & & 2 & & 5 & \\
\hline Total & 100 & 100 & 100 & 100 & 100 & 100 & 100 & 100 \\
\hline $\mathrm{N}$ & 100 & 88 & 154 & 119 & 113 & 99 & 179 & 152 \\
\hline
\end{tabular}

Source: Own calculations based on TIES

figure for Estonian women was one in four. Among Russians, the situation is even worse. Forty per cent of Russian women received less than 5,000 EEK per month from employment. Only I5 per cent of Russian men earned the same amount. The situation is reversed among highly paid employees. For example, in the case of Estonians, the share of men earning at least I0,000 EEK per month exceeds the respective figure for Estonian women by 2.5 times (43 and I7 per cent, respectively).

Among Russians, the difference between men and women in percentages is smaller: 5 per cent of Russian women earn more than Io,००० EEK per month, while among Russian men it is 26 per cent. Thus, compared to men there are five times fewer Russian women earning Io, ○०० EEK or more per month.

One more fact that attracts attention is the relatively high proportion of respondents, both Russian and Estonian, who refused to answer the question concerning the income. This was even the case when respondents were asked to select the category into which their income falls instead of an exact amount. Eight per cent of Russian men and 9 percent of Russian women were non-responders. Similar figures were recorded among Estonians. The high percentage of refusals among women is surprising, since they are considered to be more patient and accurate in filling out questionnaires. A closer look at the refusals and analysis of who these people are reveals the following pattern: younger men 
between I8-25 years old, living with parents or with someone else (but not those with a spouse and/or a child or children refused more frequently to answer questions concerning their income. There were also more non-responders among people with basic or less comprehensive secondary education. Among women, refusals were more typical for young women (I8-25 years old), living in Ida-Virumaa. It is fair to assume that representatives of those groups earn relatively little money and this is why they are reluctant to declare it. This also explains the relatively high level of refusals among both Russians and Estonians.

\subsubsection{Access to the highly paid segment}

Previous research, as well as the data supplied by Statistics Estonia, shows that the main issue related to the income inequality between Estonians and non-Estonians is the overrepresentation of Estonians among high overall income receivers (Kasearu \& Trumm 2008), as well as high wage earners (Pavelson 2002). This is of more importance than the overrepresentation of non-Estonians among those who receive low (both overall and wage) income. Estonian men are usually seen as the most advantaged, while non-Estonian women are the most disadvantaged group. Data in Table 6.3 seems to reflect this, when comparing second-generation Russians with their Estonian counterparts. For this reason, our next focus is on the factors determining access to the highly paid segment.

In order to reveal the extent that ethnicity and/or social background influence the probability of belonging to the highly paid segment of employed youth, we carried out logistic regression. Table 6.4 shows the results of these analyses as odds ratios of logistic regressions. As in the previous chapter, we estimated odds ratios for four models: the first model is that of the gross effect of ethnicity. The second - human capital model - is expected to reveal whether ethnicity mediates the effect of the differential endowments of Estonians and second-generation Russians with human capital (gender and age as well-known predictors of earnings are also added). One can see that education, as an indicator of human capital, has less effect on the chances of being highly paid than might be expected. In fact, those chances turn out to be influenced, primarily, by gender, with men having almost seven times higher odds of being higher paid than women with the same level of education and belonging to the same age group. While the influence of education is not as strong as that of gender, it is still significant. Respondents with higher education have more than three times higher odds (compared to respondents with lower levels of education) of being highly paid. The impact of ethnicity remains strong enough, about the same magnitude as that of age: all other things (human capital, age, 
Table 6.4 Belonging to the highly paid segment of working youth, odd ratios, logistic regression model, $N=462$

\begin{tabular}{|c|c|c|c|c|}
\hline & $\begin{array}{l}\text { Ethnicity } \\
\text { model } \\
(1)\end{array}$ & $\begin{array}{l}\text { Human capital } \\
\text { model } \\
(2)\end{array}$ & $\begin{array}{l}\text { Model with } \\
\text { parental } \\
\text { resources (3) }\end{array}$ & $\begin{array}{l}\text { Structural } \\
\text { Model } \\
\text { (4) } \\
\end{array}$ \\
\hline \multicolumn{5}{|l|}{ Ethnicity } \\
\hline Russian & $.51 \% * *$ & $.44 * \cdots *$ & $.39 * * *$ & $.36 * \cdots *$ \\
\hline \multicolumn{5}{|l|}{ Estonian (reference group) } \\
\hline \multicolumn{5}{|l|}{ Gender } \\
\hline Male & & $7.32 \cdots$ & 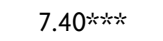 & $8.25 \cdots \cdots$ \\
\hline \multicolumn{5}{|l|}{ Female (reference group) } \\
\hline \multicolumn{5}{|l|}{ Age group } \\
\hline $18-25$ & & $.44 \%$ & $.40 * * 2 *$ & 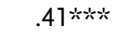 \\
\hline \multicolumn{5}{|l|}{ 26-35 (reference group) } \\
\hline \multicolumn{5}{|l|}{ Education } \\
\hline Lower than higher & & $.32 * * *$ & $.40 * * 2 *$ & $.42 \% *$ \\
\hline \multicolumn{5}{|l|}{ Higher (reference group) } \\
\hline \multicolumn{5}{|l|}{ Parental education } \\
\hline Lower than Higher & & & $.40 \%$ 的 & $.47 \%$ \\
\hline \multicolumn{5}{|l|}{ Higher (reference group) } \\
\hline \multicolumn{5}{|l|}{ Region } \\
\hline Tallinn & & & & $2.94 \% * \%$ \\
\hline \multicolumn{5}{|l|}{ Kohtla-Järve (reference group) } \\
\hline \multicolumn{5}{|l|}{ Segment of economy } \\
\hline Private & & & & .76 \\
\hline \multicolumn{5}{|l|}{ Public (reference group) } \\
\hline \multicolumn{5}{|l|}{ Branch of industry-ethnic segment } \\
\hline Russian employees overrepresented & & & & 1.22 \\
\hline Mixed & & & & 1.18 \\
\hline \multicolumn{5}{|l|}{ Russian employees } \\
\hline \multicolumn{5}{|l|}{ underrepresented (reference group) } \\
\hline \multicolumn{5}{|l|}{ Mother tongue of colleagues } \\
\hline \multirow{2}{*}{\multicolumn{5}{|c|}{ Other (reference group) }} \\
\hline & & & & \\
\hline \multicolumn{5}{|l|}{ Ethnicity of supervisor } \\
\hline \multirow{2}{*}{\multicolumn{5}{|c|}{$\begin{array}{l}\text { The same as of respondent } \\
\text { Other (reference group) }\end{array}$}} \\
\hline & & & & \\
\hline \multicolumn{5}{|l|}{ Relatives in city } \\
\hline No & & & & .77 \\
\hline \multicolumn{5}{|l|}{ Yes (reference group) } \\
\hline \multicolumn{5}{|l|}{ Friends of different ethnicity } \\
\hline None & & & & $.61+$ \\
\hline Very few & & & & .81 \\
\hline At least some (reference group) & & & & \\
\hline Constant & .97 & 1.29 & $2.24 * *$ & 1.51 \\
\hline Pseudo R square & .04 & .30 & .33 & .38 \\
\hline
\end{tabular}

***:Effect significant at $p<0.001$

$* *$ Effect significant at $p<0.01$

*Effect significant at $p<0.05$

+ Effect significant at $p<0.10$

Source: Own calculations based on TIES 
gender) being equal, second-generation Russians still have half the chance of attaining a highly paid job.

The next model takes into account parental resources. Table 6.4 provides evidence that parental education matters. Those who have parents with higher education (compared to all others) are twice better placed to become higher paid. This effect is quite independent of the impact of other factors included into the model and comparable with the influence of ethnicity and age. Thus, it is a clear disadvantage to be of the 'wrong' ethnicity, as well as of the 'wrong' gender and to come from the 'wrong family'. Human capital is just one attainment characteristic among all these ascriptive ones to influence how young people in Estonia manage to get ahead.

According to the results presented in the column Structural (segmentation) model in Table 6.4, the structure of the labour market matters as well. The structural model explores the importance of different mechanisms that might influence the economic outcomes of the labour market behaviour of youth. These mechanisms include: the peculiarities of local labour markets (Tallinn versus Kohtla-Järve); the ethnic segmentation of the Estonian labour market at the level of both industry and that of the working collective; the different rules of hiring in the private and public sectors; and, on the one hand, bridging (having friends of a different ethnicity than that of the respondent) and on the other hand, bonding ties (relatives in a given city). It is rather surprising that of all these factors, only the local labour market influences the opportunities of becoming highly paid. People working in Tallinn are paid much higher than those in Kohtla-Järve and Jõhvi. Finding an appropriate job in Tallinn is just as advantageous as having higher education. This model also shows that the impact of ethnicity is still strong. This is a clear indication that discriminatory mechanisms are operating in the Estonian labour market.

The next step is to explore the importance of country-specific capital as a factor behind income differences between second-generation Russians and Estonians. The basis for this analysis is the structural model presented in Table 6.4. Excluded from this model are the variables that turned out to be insignificant and added to it are the indicators of country-specific capital. These indicators are constructed in a way that enables us to estimate their importance, not only in differentiating within the ethnic group of Russians but also in referring this differential to the Estonians as a 'standard' of country-specific human capital. As Table 6.5 shows, country-specific capital does matter and causes differences in the opportunities of Russians with similar general human capital (measured in terms of level of education).

Human capital is far from being the single most important factor of belonging to the highly paid segment of the labour market, but it still 
Table 6.5 Country-specific human capital as a factor of belonging to highly paid employed: Gross and net effects

\begin{tabular}{|c|c|c|c|c|}
\hline & \multicolumn{2}{|c|}{ Gross effect* } & \multicolumn{2}{|c|}{ Net effect*** } \\
\hline & Odds ratio & $R^{2}$ & Odds ratio & $R^{2}$ \\
\hline M1: Higher education as $\mathrm{HC}$ & & .08 & & .37 \\
\hline $\begin{array}{l}\text { Russians with lower than } \\
\text { higher education }\end{array}$ & $.23 * * *$ & & $.17 \%$ 炏火 & \\
\hline Russians with higher education & $.39 * * *$ & & $.37 * * *$ & \\
\hline $\begin{array}{l}\text { Estonians with lower than } \\
\text { higher education }\end{array}$ & $.48 *$ & & $.38 *$ & \\
\hline \multicolumn{5}{|l|}{$\begin{array}{l}\text { Estonians with higher education } \\
\text { (reference group) }\end{array}$} \\
\hline \multicolumn{5}{|l|}{ M2: Higher education and language as } \\
\hline country-specific HC & & .08 & & \\
\hline Higher education (reference group) & & & & .38 \\
\hline Lower education & $.47 * * * ;$ & & $.37 * * * *$ & \\
\hline \multicolumn{5}{|l|}{ Command of Estonian language } \\
\hline \multicolumn{5}{|l|}{ Ethnic Estonians (reference group) } \\
\hline Written Estonian is good & $.42 * * *$ & & $.39 * * * *$ & \\
\hline $\begin{array}{l}\text { Written Estonian is } \\
\text { moderate or poor }\end{array}$ & $.65+$ & & $.37 * * * *$ & \\
\hline Written Estonian is very good & .68 & & 1.05 & \\
\hline \multicolumn{5}{|l|}{ M3: Higher education and Estonian } \\
\hline citizenship as country-specific HC & & .08 & & \\
\hline Higher education (reference group) & & & & .37 \\
\hline Lower education & $.43 * * *$ & & $.37 * * * *$ & \\
\hline \multicolumn{5}{|l|}{ Estonian citizenship } \\
\hline \multicolumn{5}{|l|}{ Ethnic Estonians (reference group) } \\
\hline ‘Non-citizen' & $.52 \% *$ & & $.42 * * * *$ & \\
\hline 'Estonian citizen by naturalisation' & .73 & & .66 & \\
\hline 'Estonian citizen by birth' & $.42 * *$ & & $.41 * * *$ & \\
\hline \multicolumn{5}{|l|}{ M4: Higher education, Estonian } \\
\hline \multicolumn{5}{|l|}{ language and Estonian citizenship as } \\
\hline country-specific HC & & .09 & & \\
\hline Higher education (reference group) & & & & .38 \\
\hline Lower education & $.44 * * *$ & & $.39 \%$ & \\
\hline \multicolumn{5}{|l|}{ Command of Estonian language and } \\
\hline \multicolumn{5}{|l|}{ Estonian citizenship } \\
\hline Ethnic Estonians (reference group) & & & & \\
\hline $\begin{array}{l}\text { Poor capital: poor command of } \\
\text { Estonian language, non-citizen }\end{array}$ & $.57 *$ & & $.35 \% * *$ & \\
\hline Moderate human capital & $.46 * * *$ & & $.40 * * *$ & \\
\hline $\begin{array}{l}\text { Good capital: good command of } \\
\text { language and Estonian } \\
\text { citizenship }\end{array}$ & .92 & & 1.28 & \\
\hline
\end{tabular}

*Gross effect is measured as the odds ratio from logistic regression model with only the human capital variables.

$* *$ Net effect is measured as the odds ratio from logistic regression model that in addition to human capital variables includes also gender, age, city.

Source: Own calculations based on TIES 
matters. Table 6.5 shows that higher education does provide secondgeneration Russians and their Estonian counterparts with different returns in terms of the probability of belonging among the higher earners. It is difficult to say which one of the country-specific capitals - very good knowledge of the Estonian language (being very proficient in written Estonian) or Estonian citizenship - is of greater help, because their effect is overlapping. In any case, without either of them the chances of making progress in the Estonian labour market are quite low, especially for those with the unfortunate luck of being born a woman, into the wrong family (with poorly educated parents) and in the wrong place (not in the capital city).

\subsection{Conclusion}

This chapter has addressed the issue of income inequality between second-generation Russians and their Estonian counterparts. The problems of an ethnic income gap have been frequently documented in many developed countries in recent decades. At the same time, much less is known about the second generation of immigrants and their earnings. Do they also earn less compared to the native population? In principle, the second generation can be expected to fare better than the first one.

In Estonia, the second generation of immigrants has also received little attention and the income disparity studied even less frequently. There are studies concerning the position of immigrants in the Estonian labour market as a whole, but not relating to the second generation. Moreover, the concept of the second generation is hardly used either in public or in scientific debate and instead issues of 'nonEstonian youth' are tackled. As a result, there are almost no studies dealing with the question of income from the comparative point of view, i.e. whether or not there is equality or inequality between secondgeneration Russians and the native population.

Our comparison of second-generation Russians aged I8-35 to their Estonian counterparts shows that the share of second-generation Russians in paid employment is lower compared to natives. Moreover, Estonians earn more compared to Russians. Our data also demonstrates an obvious gender wage gap, especially among Russians. The general trend is that Russians are overrepresented among low-paid employees and underrepresented among those receiving high wages.

Based on logistic regression, we can conclude that the impact of ethnicity on the probability of belonging among the highly paid employees is strong enough, about the same magnitude as that of age. Even with all the important factors (human capital, age, gender, region, parental education) being equal, second-generation Russians still have half the 
chance of attaining a highly paid job. In terms of the importance of country-specific capital as a factor of belonging to the highly paid segment of workers, we can conclude that contrary to 'standard' expectations, both very good knowledge of the Estonian language and Estonian citizenship differentiate the labour market outcomes of second-generation Russians. It is not surprising that the chances to get ahead in the Estonian labour market without either of these are quite low. Rather surprising is the fact that the endowment of second-generation Russians with country-specific capital is so highly differentiated, or has such power to differentiate their opportunities. This is especially worrisome in the context of the processes of social reproduction in Estonia. The opportunities for youth to prolong their period of study are clearly dependent on the employment of their parents. The probability of belonging to the group of highly paid workers depends on the level of the parents' education (see Lindemann in this volume who describes how access to high labour market occupational positions depends on the language skills of parents). Moreover, the results of our analyses show that labour market outcomes also depend on gender and the local labour market. In short, it is especially bad luck to be born a woman and to be born in the wrong place (not in the capital city).

\section{References}

Aasland, A. (I997), 'Ethnic groups and living conditions: A study of unemployment in the Baltic states', in A. Aasland, K. Knudsen, D. Kutsar, I. Trapenciere (eds.), The Baltic countries revisited: Living conditions and comparative challenges, I05-II9. The NORBALT Living Conditions Project. Oslo: Fafo Report 230.

Adsera, A. \& B.R. Chiswick (2007), 'Are there gender and country of origin differences in immigrant labor market outcomes across European destinations?', Journal of Population Economics 20: 495-526.

Anderson, B., B. Silver, M. Titma \& E. Ponarin (I996), 'Estonian and Russian communities', International Journal of Sociology 26 (2): 25-45.

Anspal, S. (2008), 'Integration in the labour market', in State integration programme 20082013: Final report on needs and feasibility research, I90-242. Tallinn: PRAXIS Center for Policy Studies.

Antecol, H., D.A. Cobb-Clark \& S. Trejo (2003), 'Human capital and earnings of female immigrants to Australia, Canada and the United States', in J.G. Reitz (ed.), Host societies and the reception of immigrants, 327-359. San Diego: Center for Comparative Immigration Studies.

Baker, M. \& D. Benjamin (I994), 'The performance of immigrants in the Canadian labor market', Journal of Labor Economics i2: 369-405.

Barr, N. (2004), Economics of the welfare state. New York: Oxford University Press.

Becker, G.S. (I964), Human capital: A theoretical and empirical analysis with special reference to education. New York: Columbia University Press.

Black, D., A. Haviland, S. Sanders \& L. Taylor (2006), 'Why do minority men earn less? A study of wage differentials among the highly educated', Review of Economic Studies 88 (2): 300-3I3. 
Borjas, G.J. (1985), 'Assimilation, changes in cohort quality, and the earnings of immigrants', Journal of Labor Economics 3 (4): 463-489.

Borjas, G.J. (I995), 'Ethnicity, neighborhoods and human capital externalities', The American Economic Review 85 (3): 365-390.

Bovenkerk, E., M. Gras \& D. Ramsoedh (I995), 'Discrimination against migrant workers and ethnic minorities in access to employment in the Netherlands', International Migration Papers 4. Geneva: ILO.

Case, K. \& R. Fair (2000), Principles of economics. Upper Saddle River: Pearson Education.

Chiswick, B.R. (1978), 'The effect of Americanization on the earnings of foreign-born men', Journal of Political Economy 86: 897-921.

Chiswick, B.R. \& P.W. Miller (I995), 'The endogeneity between language and earnings: International analyses', Journal of Labor Economics I3 (2): 246-288.

Crul, M. \& H. Vermeulen (2003), 'The second generation in Europe', International Migration Review 37 (4): 965-986.

Friedberg, R.M. (2000), 'You can't take it with you? Immigrant assimilation and the portability of human capital', Journal of Labor Economics I8 (2): 22I-25I.

Le Grand, C. \& R. Szulkin (2002), 'Permanent disadvantage or gradual integration: Explaining the immigrant-native earnings gap in Sweden', Labour I6 (I): 37-64.

Le Grand, C., R. Szulkin \& M. Thalin (I994), 'Organizational structures and job rewards in Sweden', Acta Sociologica 37: 23I-253.

Hallik, K. (I998), 'Non-Estonians: Historical and demographical background', in M. Heidmets (ed.), Russian minority and challenges for Estonia, 13-27. Tallinn: Tallinn Pedagogical University.

Hammarstedt, M. (2009), 'Intergenerational mobility and the earnings position of first-, second-, and third-generation immigrants', KYKLOS 62 (2): 275-292.

Heath, A. (2007), 'Crossnational patterns and processes of ethnic disadvantage' in A. Heath \& S.Y. Cheung (eds.), Unequal chances: Ethnic minorities in western labour markets, 639-95. Oxford: Oxford University Press.

Heath, A. \& Y. Brinbaum (2007), 'Guest editorial: Explaining ethnic inequalities in educational attainment', Ethnicities 7 (3): 29I-305.

Heath, A. \& S.Y. Cheung (2007), 'The comparative study of ethnic minority disadvantage' in A. Heath \& S.Y. Cheung (eds.), Unequal chances: Ethnic minorities in western labour markets, I-44. Oxford: Oxford University Press.

Helemäe, J. (2008), 'Tööalane eneseteostus ja selle tajumise võimalused', in Integratsiooni monitooring 2008. Aruanne (Integration of Estonian Society, Monitoring 2008. Report) 24-50. www.meis.ee. Accessed I3 March 2009.

Huffman, M.L. (2004), 'Gender inequality across local wage hierarchies', Work and Occupations 3I (3): 323-344.

Husted, L., H.S. Nielsen, M. Rosholm \& N. Smith (200I), 'Employment and wage assimilation of male first generation immigrants in Denmark', International Journal of Manpower 22 (I/2): 39-68.

Inglis, C., S. Model (2007), 'Diversity and mobility in Australia', in A. Heath \& S.Y. Cheung (eds.) Unequal chances: Ethnic minorities in western labour markets, 45-IO2. Oxford: Oxford University Press.

Jurajda, S. (2003), 'Gender wage gap and segregation in enterprises and the public sector on late transition countries', Journal of Comparative Economics 3I (2): 199-222.

Kalleberg, A.L. \& I. Berg (1987), Work and industry: Structures, markets, and processes. New York: Plenum Press.

Kasearu, K. \& A. Trumm (2008), 'Eesti- ja venekeelse elanikonna aineline olukord ja eluga rahulolu', in Integratsiooni monitooring 2008. Aruanne (Integration of Estonian Society, Monitoring 2008. Report). www.meis.ee. Accessed I3 March 2009. 
Kroncke, C. \& K. Smith (I999), 'The wage effects of ethnicity in Estonia', Economics of Transition 7 (I): I79-199.

Leping, K.-O. \& O. Toomet (2008), 'Emerging ethnic wage gap: Estonia during political and economic transition', Journal of Comparative Economics 36 (4): 599-6r9.

Mincer, J. (1974), Schooling, experience and earnings. New York: Columbia University Press.

Nielsen, H.S., M. Rosholm, N. Smith \& L. Husted (2004), 'Qualifications, discrimination, or assimilation? An extended framework for analyzing immigrant wages gaps', Empirical Economics 29: 855-883.

Noorkõiv, R., P.F. Orazem, A. Puur \& M. Vodopivec (I998), 'Employment and wage dynamics in Estonia, I989-I995', Economics of Transition 6 (2): 48I-503.

Orazem, P. \& M. Vodopivec (2000), 'Male-female differences in labour market outcomes during the early transition to market: the cases of Estonia and Slovenia', Journal of Population Economics I3: 283-303.

Pavelson, M. (2000), 'Socio-economic integration: Employment and incomes', in Integration of Estonian Society: Monitoring 2000. Report, 22-27. Tallinn: MEIS, TPU IISS.

Pavelson, M. (2002), 'Work, income and coping: Socio-economic background of integration', in Integration of Estonian Society: Monitoring 2002. Report, 50-64. Tallinn: MEIS, TPU IISS.

Randoja, M. (2008), 'Gender wage gap', in R. Eamets (ed.), A glimpse into the working life, I26-I33. Tallinn: Statistics Estonia.

Reskin, B. \& I. Padavic (I994), Women and men at work. Thousand Oaks: Pine Forge Press.

De la Rica, S., J.J. Dolado \& V. Llorens (2008), 'Ceilings or floors? Gender wage gaps by education in Spain', Journal of Population Economics 2I (3): 751-776.

Rosenfeld, R.A. \& A.L. Kalleberg (I990), 'A gross-national comparison of the gender gap in income', American Journal of Sociology 96: 69-106.

Rõõm, T. \& E. Kallaste (2004), Naised-mehed Eesti tööturul: Palgaerinevuste hinnang. Poliitikaanalü̈̈s. Tallinn: Poliitikauuringute Keskuse Praxis väljaanne No. 8.

Schoeni, R. (1997), 'New evidence on the economic progress of foreign-born men in the I970s and I980s', Journal of Human Resources 32: 683-740.

Tesser, P. \& J. Dronkers (2007), 'Equal opportunities or social closure in the Netherlands?', in A. Heath \& S.Y. Cheung (eds.), Unequal chances: Ethnic minorities in western labour markets, 359-402. Oxford: Oxford University Press.

Treiman, D.J. (2007), 'The legacy of apartheid: Racial inequalities in the new South Africa' in A. Heath \& S.Y. Cheung (eds.), Unequal chances: Ethnic minorities in western labour markets, 403-450. Oxford: Oxford University Press.

Trumm, A. (2005), Poverty in Estonia: Overview of main trends and patterns of poverty in the years 1996-2002. Oslo: Fafo-Report No. 497.

Vöörmann, R. (2000), 'Men and women in the labour market', in P. Maimik, K. Mand \& U.-M. Papp (eds.), Towards a balanced society: Women and men in Estonia, 46-53. Tallinn: Ministry of Social Affairs of Estonia, United Nations Development Programme.

Vöörmann, R. \& J. Helemäe (2003), 'Ethnic relations in Estonia's post-Soviet business community', Ethnicities 3 (4): 509-530. 



\title{
7 Housing conditions and neighbourhood satisfaction
}

\author{
Liis Ojamäe and Katrin Paadam
}

\subsection{Introduction}

Questions about distinct opportunities for accessible and affordable housing related to ethnic minority issues did not form part of the Estonian public policy discourse until after the fundamental societal transformation and reintroduction of capitalist relations towards the end of the last century. Likewise, residential and regional patterns of segregation, which are based on an ethnic rather than a socio-economic differentiation of inhabitants, were not formed recently but rather, are embedded in the specific socio-structural context of the previous Soviet socialist system. The legacy of these past societal developments is apparent and, thus, creates a unique socio-physical situation in urban residential contexts, as well as in the entire Estonian housing field. In European cities, research on minority ethnic groups has been focused on explaining the differences between native-born and minority ethnic groups in segregation patterns and housing conditions. Extensive research, which began in the United States in the I920s and in Europe in the I970s, has revealed the disadvantaged position of ethnic minorities in the field of housing. They have been found to occupy the worst segments of housing and residential areas, something reinforced by their insecure position on the labour market (see Özüekren \& Van Kempen 2003). It has been documented that minority groups have greater difficulties in accessing social housing (e.g. in the Netherlands, France and Austria), as well as encountering the prejudice and discrimination of landlords or housing agencies in the private sector (ibid.: I63, I68; see also Teixeira \& Murdie 1997). A lack of interethnic cultural knowledge and communication skills prevents immigrants from gaining an understanding of the local housing system. This, in turn, contributes to their low position in the housing field. The concentration of immigrants into poor residential areas is viewed as a restriction on the scope of individual participation (see Aalbers \& Deurloo 2003) in other fields of the host society. 
However, A. Sule Özüekren and Ronald van Kempen (2003) have stressed the complexity of ethnic segregation and integration processes in the housing field, particularly in relation to the actual diversity and dynamics of ethnic minority groups, as well as to the local and countryspecific structural differences between the host countries. Ethnic minorities form diverse groups with differentiated collective and individual capacities, which lead to distinct housing careers developing within the particular structural contexts. Therefore, instead of conceiving minority ethnic groups as being trapped in their neighbourhoods, a more nuanced approach is needed for considering the differences within groups, over time and between locations (see Özüekren \& Van Kempen 200I). It has been shown that groups with diverse levels of economic well-being can use ethnicity as a resource in satisfying their housing needs; a preference to live within their own ethnic group and to maintain social contacts in the ethnic community can lead to a choice-led or voluntary segregation (Tomlins, Johnson \& Owen 2002; Teixeira 2007). Furthermore, there are also groups of economically highly successful immigrants, mostly from industrialised societies, who are not often addressed in respective research (Aalbers \& Deurloo 2003: I98, 207) although they too tend to concentrate into certain neighbourhoods and have a low level of cultural integration into the host society. These tendencies suggest that ethnic segmentation should not necessarily be associated with low levels of economic capacity or poverty. Such observations show the need for reconceptualising the notion of ethnic concentration. Since it has become 'an issue of liveability of the neighbourhood' (see Malheiros 2002), it calls for interpretations on a broader scale of cultural and social sustainability. The spatial concentration of people with homogeneous individual capacities, high or low, reduces the socio-economic diversity of the area and therefore can lower its liveability.

In the context of public policy, residential segregation is generally perceived as a factor that restricts the cultural and structural integration of ethnic minorities into the host society (see Aalbers \& Deurloo 2003; Schönwälder \& Söhn 2009). To prevent such processes, mixing tenures and housing types in neighbourhoods has been used as a public policy measure, for example in Nordic countries, as well as in the UK, Germany and elsewhere (see Ham \& Feijten 2008; Schönwälder \& Söhn 2009). Although European countries present a variety of welfare models and approaches to ethnic segregation (Arbaci 2007), most of the research on European cities has shown that although the concentrations of disadvantaged individuals are perceptible in ethnic segregation areas, the socio-spatial contrasts are more modest and dynamic compared to the situation in the US. Therefore, they are less likely to bring about stigmatisation and a lack of integration in European cities 
(Musterd \& Deurloo 2002; Özüekren \& Van Kempen 2003; Schönwälder \& Söhn 2009).

Ethnic relations and the formation of patterns of behaviour in the housing field are deeply interconnected with the development of country-specific cultural and socio-economic structures. In this chapter, we focus on the development of the Estonian housing field with an emphasis on the strategies and structural opportunities of different ethnic groups.

\subsection{Formation of the Estonian housing field and the current question}

The current trends evolving in the Estonian housing field, both at the level of individual agency and on the structural level, are to a considerable degree related to the fundamental societal transformations of the twentieth century. These processes encompass the nationalisation of property and changes to the entire housing system during the Soviet occupation starting in the I940s, as well as the denationalisation of property after regaining independence and restoring capitalist relations in I99I. The most salient structural result of this latest transformation concerns 'ownership reform', which dramatically enlarged the proportion of privately owned housing, with figures reaching 96 per cent in 2007 (Tallinn City Government 2008).

Much research focuses on issues of the privatisation of formerly public housing - a process that has concerned an overwhelming proportion of the population in the post-socialist period. At the same time, the restitution of expropriated property, which is considered to be the primary legal procedure in the restoration of property rights and in the creation of the institutional setting for the arrangement of housing relations in renewed societies, has received very little attention. Nevertheless, while in a number of Central and Eastern European (CEE) countries, including those liberated from the Soviet regime, restitution was an inevitable question to be addressed to enable denationalisation and pave the way for privatising housing (Fisher \& Jaffe 2000), it also entailed severe complications for individual housing careers and prospects for interrelated performances in other fields.

There are no obvious differences in the effects of these recent processes on ethnic groups in Estonia. Instead, restitution and privatisation have affected the differentiation of Russian and Estonian population groups, indirectly and circumstantially, in relation to the positions taken by individuals and families in the housing field before, during and after the Soviet occupation. The consequences of the denationalisation of housing property are partly accidental, since no individual strategies 
constructed before the Soviet regime or within the Soviet housing system of predominantly public housing could foresee these profound transformations of social systems and the reorganisation of relations in the housing field. Hence, the current position and future prospects of individuals, families or households in the housing field can be understood through the connection, which builds between their present and past structural positions.

In order to understand the complicated context of denationalisation in the I990s, it has to be emphasised that the restitution of property has been the basic assumption behind, first of all, defining public property and, secondly, identifying the eligible contingencies. Only buildings constructed before World War II, i.e. before nationalisation and the introduction of the Soviet housing system constitute restituted housing. At the beginning of the I990s' ownership reform, the old stock made up only 9-II per cent of the total housing stock (Kursis I999: I6). This implies that restituted property also formed only a small proportion of the stock designated for denationalisation in Tallinn and other towns in Estonia (Omanikele tagastatud... I998) and, evidently, concerned a relatively small proportion of residents. Tenants in restituted dwellings were deprived of the eligibility to privatise the formerly public property, which was the rule that applied to the rest of the sitting tenants in houses built after World War II, during the Soviet regime, and owned primarily by municipalities or the state.

The clearly advantageous position of immigrants from other parts of the Soviet Union in the dominating public housing distribution system was expressed in easier access to the new large-scale blocks built from the I96os onwards. According to the logic of the previous housing system, the probability that Estonians were caught within the restrictions of restitution was relatively high. Similarly, Estonian rather than Russian inhabitants had a higher potential of regaining housing property expropriated in the I940s, because the majority of Russians were Soviet immigrants who did not possess property in Estonia before World War II. A small group of Russian inhabitants had a higher potential of becoming disadvantaged due to restitution. This was the former privileged group of Soviet high political officials, also of Russian origin, who had been distributed housing in the older part of the block. The quality of this housing soon became appreciated when the deficiencies of large blocks were revealed. The return of property restored social justice by clearly increasing the economic capacity of restitutees and, conversely, deprived tenants of equal opportunities for property privatisation by decreasing their economic prospects on the housing market, as has been asserted elsewhere (Paadam 2009).

It has been well documented in social research about Estonia, as well as other parts of the former Soviet territory and CEE countries, that a 
higher position in the socialist social and, specifically, political hierarchies, including also employment in high-priority enterprises (Szelenyi \& Szelenyi 1995; Ladanyi I995; Mandic \& Clapham I996; Paadam 2003; Kulu \& Tammaru 2003; Gentile \& Tammaru 2006), guaranteed an advantaged position in the housing field and allowed for more control over the allocation of resources, as well as distribution of housing. This suggests that the structural differentiation of ethnic groups in Estonia, salient on urban residential and regional spatial scales with either the dominance of the native or immigrant population, is embedded, to a considerable degree, in the history of the socio-structural developments in the field and in society (see Kemeny I992). These differences also affect opportunities for individual performance in the field. The transformation of public housing into private property by a privatisation scheme is a historical experiment that displays the past social experiences dominating the present and the future of the field, because it repositions individuals and households in the field in most unexpected ways. Concerning ethnic differentiation, it can also be associated with a synthesis of previously acquired socio-economic capacity and the ability to perform in accordance with the modern demands of all relevant fields. The principal factor, which differentiates performance on the housing market, is obviously the marketability of housing, the value attributed to the privatised property having been obtained in the former system and established as property in the present system. Currently, the urban housing scene is dominated by the multi-storied blocks of distinct size, age, condition and market value, with a great share of the stock constructed between the I96os and I980s. With small historical residential centres, and a particularly outstanding medieval core in Tallinn, the towns of Estonia have been expanding from prevailingly wooden residences (Rahva demograafiline... I924), through areas mixed with stone buildings from different periods, to large-scale blocks towards the end of the twentieth century. The construction of these blocks ceased as the system changed in the I990s and they have become a thing of the past. The current choices are advancing towards gradually expanding new single-family housing areas.

The majority of rental flats in blocks in Estonia have not been particularly spacious. Those rental blocks built before World War II mainly offered small flats with one or two rooms. In the I930s, the situation improved and the average number of rooms in rental flats increased to 2.5 (Eesti arvudes I920-1935, I937). During the Soviet period, the dominating housing type in Tallinn, as well as in the rest of Estonia, was a two-room flat. The number of flats with three rooms increased by the end of the ig8os (Social Trends 2 200I). The average pre-war floor space per capita was $13.8 \mathrm{~m}^{2}$. This decreased for obvious reasons, such as war damages, down to $9.3 \mathrm{~m}^{2}$ in 1945 . By 1955 , this had shrunk further to 
9.I $\mathrm{m}^{2}$ and only a small increase to $10.8 \mathrm{~m}^{2}$ by 1960 demonstrates the increased number of immigrants and the subsequent demand for housing, which continued to be in short supply throughout the Soviet housing era. During the years I960-1985, an increase up to $\mathrm{I} 8 . \mathrm{I} \mathrm{m}^{2}$ is recorded and by the end of the I980s up to $21 \mathrm{~m}^{2}$. In 2007 , the availability of space per capita in Estonia was $28.9 \mathrm{~m}^{2}$ (Social Trends 4 2007). The dynamics of the availability of floor space also reflect the data on density in flats. For example, in Tallinn the density index improved considerably from I.6 to I.3 between the I920s and I930s. This situation worsened and the figure rose to 2.I in the post-war occupation period until the ig6os. Towards the end of the I980s, figures began to show a slow decrease (Eesti arvudes I920-I935, I937; Bruns I993). The current density index in Estonia is 0.9 (Social Trends 4 2007).

Previous analyses on ethnic differences in the housing field in the I980s have shown that while Estonians had more living space at their disposal, Russians occupied dwellings of a higher level of comfort (Kulu \& Tammaru 2003; Kulu 2003a). These distinctions can, largely, be explained by the Soviet policy for public housing 'distribution', as well as by predominant preferential differences between ethnic groups (Paadam 2003; Tomson 2004; Kulu \& Tammaru 2003). The Estonians' stronger preference for single-family housing is embedded in sociostructural, cultural and historical circumstances, while the Russian population's dominance in blocks is largely a consequence of access privileges for immigrants from the Soviet regions. Although a slight change in preferences is noted in the most recent research (Ojamäe \& Paadam 2009), we assume that such differences in basic housing conditions have remained characteristic of the second generation of Russian and Estonian youth. Differences in cultural preferences and economic status allow us to predict the continuous overrepresentation of Russians in blocks of flats and in less spacious situations. Compared to their parents' generation, young Russians and young Estonians start their independent housing career in completely distinct societal circumstances, in the context of a market-oriented housing field with a marginal public rental sector. This suggests no significant differences between the housing ownership strategies of ethnic groups, because structurally there are only a few alternatives to owner occupation. In the following empirical analysis, we expect to find the patterns of late-Soviet housing conditions still present among second-generation Russians and Estonians: a greater number of Russians having less space at their disposal (mostly in blocks) and, respectively, a greater number of Estonians living in more spacious dwellings (also mostly in blocks but with a greater share in single-family houses). We expect to find no differences in tenure structures with predominant owner occupation. 
Research in the Netherlands has shown a complex relation between ethnic segregation and neighbourhood satisfaction levels: whereas concentrations of immigrants from industrial countries have a high level of neighbourhood satisfaction, the indicators for immigrants from non-industrial countries vary along the ethnic groups and physical structures of particular neighbourhoods (Aalbers \& Deurloo 2003: 206). Those living among their own ethnic group demonstrate higher neighbourhood satisfaction (Van Ham \& Feijten 2008). Previously conducted research in Estonia and, specifically, in Tallinn prior to the latest fundamental societal transformation (Pavelson I989) clearly demonstrated similar results on ethnically segregated areas. Moreover, these areas of either Russian or Estonian dominance are characterised by distinctly built environments, with either predominantly large-scale blocks or single-family houses. Despite the rather developed ethnic residential segregation, the socio-economic residential segregation of the Soviet period was relatively lower in Estonia than in Western societies. There is, however, no reason to state that the previous system of housing access was egalitarian. On the contrary, it is apparent from a number of qualitative, as well as quantitative CEE-wide studies, that individuals in higher or privileged positions in the socialist social hierarchy had a wider range of choices in times of deficit and easier access to higher quality housing and less expensive housing options. By contrast, choices for lay-people were severely restricted (Mandic \& Clapham I996; Häußermann \& Oswald 200I; Paadam 2003; Gentile \& Tammaru 2006). The socialist system of housing allocation can be identified, accordingly, as having produced a kind of camouflage effect on both ethnic and socio-economic segregation, in less explicit physical reflections. Although respective changes are in progress, we can assume that the problem of ethnic 'pockets of poverty', or ethnicity-driven formation of poor neighbourhoods, which would drastically limit the minorities' life opportunities and their socio-economic well-being, does not exist in modern Estonia. Consequently, in the following analysis of the TIES database, we expect to find no significant differences in general neighbourhood satisfaction between second-generation Russians and their Estonian counterparts, assuming that the ethnic composition of a neighbourhood influences neighbourhood satisfaction.

\subsection{Variables and methods}

To investigate differences in housing conditions, we will first examine ethnic differences in key variables by defining the structural circumstances of the housing situation: the dwelling type, housing ownership and spatial conditions. In order to measure spatial conditions, a density 
index was calculated based on the number of household members and the number of rooms in a dwelling. Cases where the number of residents exceeded the number of rooms in a dwelling were defined as crowded spatial situations.

The survey questionnaire comprised a section of eight statements on different aspects of neighbourhood satisfaction, with a five-level Likert scale. The statements concerned personal attachment to the neighbourhood, neighbourhood-based sense of social security and social contacts, as well as the future liveability of the neighbourhood. A factor analysis of the statement block gave one factor with an initial Eigenvalue over one (2.3) to six statements out of eight, enabling us to calculate a sum index based on the six statements ('I am attached to the neighbourhood I currently live in'; 'There is hardly any vandalism in this neighbourhood; I have good contacts with my direct neighbours'; 'There is a lot of garbage on the streets in this neighbourhood'; 'People hardly know each other in this neighbourhood'; 'There is a lot of crime in this neighbourhood'). For the calculation of this particular index, all statements were first recoded so that the smallest value would indicate the strongest satisfaction, and then the 5-level scale was re-coded into a three-level scale: I) Strongly agree/agree; 2) Neither agree nor disagree; 3) Disagree/ strongly disagree. This resulted in an index with values of between 6-I8, which was then divided into two groups: I) Satisfied (index value 6-9, 57 per cent) and 2) Dissatisfied (index value Io-I8, 43 per cent). Since the TIES database does not include any data on the actual neighbourhood characteristics, the analysis is based on subjective estimations only.

In order to follow the individual housing strategies of young Russians and Estonians, the respondents were divided into a group living separately in their own households (73 per cent of Russians and 7I per cent of Estonians) and a group continuing to live in their parental households (27 per cent of Russians and 29 per cent of Estonians). In this respect, the data show no obvious distinctions between the ethnic groups and refer instead to a common pattern. The housing conditions of the group of young Russians and Estonians still living at their parents' home reflect the housing strategies of their parents, rather than their own choices. Yet the data on this group's current housing is resourceful as an indicator of the housing choices and careers of the 'first generation' of both Russians and Estonians.

To study the differences between ethnic groups in terms of the potential spatial situation and neighbourhood satisfaction, we applied a logistic regression analysis by including variables into the model step by step. Ethnicity is entered into the first model and in the subsequent models the role of different explanatory variables are tested. For neighbourhood satisfaction, different models were calculated for both ethnic groups. 


\subsection{Housing conditions and ownership status}

The analysis of the TIES database shows the presence of differences between ethnic groups in terms of the dwelling types at the disposal of the first and second generations (see Table 7.I). A number of earlier studies conducted in Estonia (Org 1989; Tallinna linnaelanike... I995; Paadam I996; Pavelson 2000; Paadam 2003; Tomson 2004; Ruoppila 2006) reveal that the distinct practices of residing in different types of residential buildings has been a long-standing and evidently intergenerational differentiating device between the two ethnic groups.

It is not possible to conclude from the data whether the current distinct practice of young Estonians and Russians is a clear reflection of cultural dispositions or whether it is an affordability issue. In other words, whether young Estonians are more inclined and/or able to move into family houses compared to second-generation Russians.

The analysis of tenure relations (see Table 7.2) show more variation between the first and second generations under investigation, appearing to be indicative of their distinct phases of life, of their societal

Table 7.1 Dwelling types of respondents residing on their own or in parental households (in \%)

\begin{tabular}{lcccccr}
\hline & \multicolumn{2}{c}{ Russian } & & \multicolumn{2}{c}{ Estonian } & \\
\cline { 2 - 3 } Dwelling types & $\begin{array}{c}\text { One's own } \\
\text { household }\end{array}$ & $\begin{array}{l}\text { Parental } \\
\text { household }\end{array}$ & & $\begin{array}{l}\text { One's own } \\
\text { household }\end{array}$ & $\begin{array}{l}\text { Parental } \\
\text { household }\end{array}$ & Total \\
\hline Blocks of flats & 98 & 96 & & 87 & 86 & 93 \\
Family houses* & 2 & 4 & & 13 & 14 & 7 \\
Total & 100 & 100 & & 100 & 100 & 100 \\
\hline
\end{tabular}

*Includes detached houses, semi-detached houses and row-houses

Source: Own calculations based on TIES

Table 7.2 Tenure status of respondents residing on their own and in parental households (in \%)

\begin{tabular}{|c|c|c|c|c|c|}
\hline \multirow[b]{2}{*}{ Tenure status } & \multicolumn{2}{|c|}{ Russian } & \multicolumn{2}{|c|}{ Estonian } & \multirow[b]{2}{*}{ Total } \\
\hline & $\begin{array}{l}\text { Own } \\
\text { household }\end{array}$ & $\begin{array}{l}\text { Parental } \\
\text { household }\end{array}$ & $\begin{array}{l}\text { Own } \\
\text { household }\end{array}$ & $\begin{array}{l}\text { Parental } \\
\text { household }\end{array}$ & \\
\hline $\begin{array}{l}\text { Owned by respondent } \\
\text { or partner }\end{array}$ & 62 & 10 & 50 & 9 & 43 \\
\hline $\begin{array}{l}\text { Owned by other family } \\
\text { member }\end{array}$ & 21 & 85 & 29 & 86 & 42 \\
\hline Private rental & 6 & 0 & 14 & 2 & 7 \\
\hline Municipal rental & 4 & 0 & 1 & 0 & 2 \\
\hline Other & 1 & 0 & 2 & 1 & 2 \\
\hline \multirow[t]{2}{*}{ Do not know } & 6 & 5 & 4 & 2 & 5 \\
\hline & 100 & 100 & 100 & 100 & 100 \\
\hline
\end{tabular}

Source: Own calculations based on TIES 
circumstances at time of acquisition of housing property, and of the situation in the local residential markets.

The high ownership rate of the parental households is largely due to the ownership reforms of the I990s. This enabled people to obtain property in favourable conditions through a special voucher system launched for housing privatisation (Jaffe I995; Kursis I999). The reality for many CEE countries during the system transition - as Hegedüs and Tosic pertinently indicate - was that sitting tenants in the formerly public housing were able to purchase property at give-away prices (Hegedüs \& Tosic I998). Their descendants in the next generation, however, had to buy their housing at market prices, which, largely for affordability reasons, prevented a number of young adults from entering the property market. Instead, they were forced to enter into the rental markets. Consequently, the share of tenants among these respondents is higher than the average, especially in Tallinn where 23 per cent of young Russians and 26 per cent of young Estonians are renting their flats, mostly in the private sector (the respective figure for Estonia was I6 per cent in 2006; Social Trends 4 2007). Hence, we observe greater differences in the entry into owner-occupation in spatial and generational terms rather than in ethnic terms.

The ratio of the number of household members to the number of rooms (see Table 7.3) is often used as a quantitative measure for the evaluation of objective housing conditions. Each member of a household having at least one room at his or her disposal can be considered as an acceptable minimum standard for spaciousness and potential privacy.

Table 7.3 shows that with the given conditions for privacy and space, there are differences between ethnic groups, as well as between individual housing strategy groups, characterised by continuous stay with par-

Table 7.3 Ratio of the number of household members to the number of rooms in a dwelling

\begin{tabular}{|c|c|c|c|c|c|}
\hline & \multicolumn{2}{|c|}{ Russian } & \multicolumn{2}{|c|}{ Estonian } & \multirow[b]{2}{*}{ Total } \\
\hline & $\begin{array}{l}\text { Own } \\
\text { household }\end{array}$ & $\begin{array}{l}\text { Parental } \\
\text { household }\end{array}$ & $\begin{array}{l}\text { Own } \\
\text { household }\end{array}$ & $\begin{array}{l}\text { Parental } \\
\text { household }\end{array}$ & \\
\hline $\begin{array}{l}\text { Density index }>1 \\
\quad \text { (More residents than rooms) }\end{array}$ & 52 & 50 & 43 & 38 & 46 \\
\hline $\begin{array}{l}\text { Density index }=1 \\
\quad \text { (Numbers equal) }\end{array}$ & 30 & 37 & 31 & 27 & 31 \\
\hline $\begin{array}{l}\text { Density index }<1 \\
\quad \text { (More rooms than residents) }\end{array}$ & 18 & 13 & 27 & 35 & 23 \\
\hline Total & 100 & 100 & 100 & 100 & 100 \\
\hline
\end{tabular}

Source: Own calculations based on TIES 
ents or moving to separate housing. Thus, we calculated the effects of ethnicity, the housing characteristics and the social background in the density index separately for those having their own housing and those staying at a parental household, in order to allow the comparison of housing conditions between the 'first' and the 'second' generations. Tables 7.4 and 7.5 indicate how different socio-economic and residential characteristics influence the probabilities of a household's access to spacious housing conditions (density index $<\mathrm{I}$ ).

In general, the analysis shows that belonging to a specific ethnic group may raise or lower the probability for obtaining a particular housing quality. Young Russians have a higher probability of having less spacious dwellings, albeit, the differences between the groups of young Russians and Estonians become less pronounced after the inclusion of indicators of socio-economic background into the model. Quite expectedly, residing in a flat (as opposed to residing in a single-family house) decreases and owner occupation increases (as opposed to renting) the probability of access to greater spaciousness. Income and employment indicators have no clear impact on spatial conditions, contrary to that of the education indicator. We conclude that the higher the education, the greater the volume of cultural capital (in Bourdieusian terms) or knowledgeability (as in Giddens) to interpret the circumstances in the housing field and on the property and rental markets, thus, providing these individuals with greater capacity and disposing them towards potentially successful housing careers. Recent housing mobility, which increases the probability of obtaining more spacious conditions, is characteristic of a specific age group under investigation, one that is at the start of their independent housing career. Those who remain single have the most spacious housing conditions, which change towards greater density if they start a family.

The model of those living in their parental home reveals no significance of ethnicity on the density index (see Table 7.5). In addition, the parents' level of education or their occupation has no significant influence on the probable attainment of specific spatial qualities.

With no difference between respondents residing on their own or respondents staying at their parents', a higher probability of having more spacious housing conditions applies to individuals who reside in family houses (as opposed to flats) and have a higher level of education. In addition, it is significant that the probability for lower density increases in residential districts of higher ethnic homogeneity, especially among young respondents residing with their parents. However, the TIES data provide no basis for further detailed analysis of this observation

The differences in the density index between ethnic groups seen in Table 7.3 can be explained by the relationship between the housing type and the ethnic composition of the neighbourhood, as a reflection of the 
Table 7.4 Access to spaciousness in households residing on their own: Logistic regression models

\begin{tabular}{|c|c|c|c|}
\hline & Model 1 & Model 2 & Model 3 \\
\hline \multicolumn{4}{|l|}{ Ethnicity (reference group: Estonian) } \\
\hline Russian & $-.55 \% * \%$ & $-.67 * * *$ & $-.42 *$ \\
\hline \multicolumn{4}{|l|}{ Gender (reference group: Female) } \\
\hline Male & & $.53 \% *$ & $.44 *$ \\
\hline \multicolumn{4}{|l|}{ Age group (reference group: $26-35$ ) } \\
\hline $18-25$ & & $.35 \% *$ & .18 \\
\hline \multicolumn{4}{|l|}{ Region (reference group: Kohtla-järve and Jõhvi) } \\
\hline Tallinn & & -.10 & -.09 \\
\hline \multicolumn{4}{|l|}{ Housing type (reference group: Family house) } \\
\hline Blocks of flats & & $-.75 *$ & $-.10 * *$ \\
\hline \multicolumn{4}{|l|}{ Ownership status (reference group: Tenant) } \\
\hline $\begin{array}{l}\text { Owner occupier, either respondent or a family } \\
\text { member }\end{array}$ & & .50 & $.91 \%$ \\
\hline \multicolumn{4}{|l|}{$\begin{array}{l}\text { Period of residence in the dwelling (reference group: } 5 \\
\text { or more) }\end{array}$} \\
\hline Four years or less & & $.56 * *$ & $.95 * * *$ \\
\hline \multicolumn{4}{|l|}{$\begin{array}{l}\text { At the age of } 15-17 \text { resided ... (reference group: In the } \\
\text { same town) }\end{array}$} \\
\hline$\ldots$ in another region & & -.40 & -.43 \\
\hline \multicolumn{4}{|l|}{$\begin{array}{l}\text { Ethnic composition of the neighbourhood (reference } \\
\text { group: Approximately } 25 \% \text { or less of same ethnicity) }\end{array}$} \\
\hline $\begin{array}{l}\text { Approximately } 75 \% \text { or more of the same } \\
\text { ethnicity }\end{array}$ & & .23 & .22 \\
\hline Approximately half of same ethnicity & & .25 & .25 \\
\hline \multicolumn{4}{|l|}{ Individual income (reference group: More than 7,001 } \\
\hline \multicolumn{4}{|l|}{ EEK per month) } \\
\hline Less than 7,000 EEK per month & & & .01 \\
\hline \multicolumn{4}{|l|}{ Employment status (reference group: Working) } \\
\hline Full-time, non-working student & & & .81 \\
\hline Other & & & $-.61 *$ \\
\hline \multicolumn{4}{|l|}{ Highest level of completed education (reference } \\
\hline \multicolumn{4}{|l|}{ group: Higher) } \\
\hline Basic or less & & & $-1.04 * *$ \\
\hline General secondary & & & $-.57 * *$ \\
\hline Vocational or professional secondary & & & $-.55 \%$ \\
\hline \multicolumn{4}{|l|}{ Marital status (reference group: Single) } \\
\hline Married or living with a partner & & & $-1.39 * * * *$ \\
\hline \multicolumn{4}{|l|}{ Having children (reference group: No) } \\
\hline Yes & & & -.19 \\
\hline Constant & .39 & .27 & 1.51 \\
\hline Pseudo R square & .02 & .10 & .24 \\
\hline Number of cases & 712 & 712 & 712 \\
\hline
\end{tabular}

w: Effect significant at $p<0.01$

$* *$ Effect significant at $p<0.05$

*Effect significant at $p<0.10$

Source: Own calculations based on TIES 
Table 7.5 Access to spaciousness in parental households: Logistic regression models

\begin{tabular}{|c|c|c|c|}
\hline & Model 1 & Model 2 & Model 3 \\
\hline \multicolumn{4}{|l|}{ Ethnicity (reference group: Estonian) } \\
\hline Russian & -.64 & -.46 & -.36 \\
\hline \multicolumn{4}{|l|}{ Gender (reference group: Female) } \\
\hline Male & & .38 & .79 \\
\hline \multicolumn{4}{|l|}{ Age group (reference group: $26-35$ ) } \\
\hline $18-25$ & & -.58 & -.86 \\
\hline \multicolumn{4}{|l|}{ Region (reference group: Kohtla-Järve and Jõhvi) } \\
\hline Tallinn & & -.06 &.-16 \\
\hline \multicolumn{4}{|l|}{ Housing type (reference group: Family house) } \\
\hline Blocks of flats & & $-2.26 * *$ & $-2.71 * *$ \\
\hline \multicolumn{4}{|l|}{ Ownership status (reference group: Tenant) } \\
\hline $\begin{array}{l}\text { Owner occupier, either respondent or a family } \\
\text { member }\end{array}$ & & -19.6 & -17.8 \\
\hline \multicolumn{4}{|l|}{ Period of residence in the dwelling (reference group: } \\
\hline \multicolumn{4}{|l|}{5 or more) } \\
\hline Four years or less & & .67 & 1.08 \\
\hline \multicolumn{4}{|l|}{$\begin{array}{l}\text { At the age of 15-17 resided... (reference group: In the } \\
\text { same town) }\end{array}$} \\
\hline$\ldots$ in another region & & .92 & 1.12 \\
\hline \multicolumn{4}{|l|}{ Ethnic composition of the neighbourhood (reference } \\
\hline \multicolumn{4}{|l|}{ group: Approximately $25 \%$ or less of same ethnicity) } \\
\hline $\begin{array}{l}\text { Approximately } 75 \% \text { or more of the same } \\
\text { ethnicity }\end{array}$ & & .74 & $1.35 * *$ \\
\hline Approximately half of same ethnicity & & $1.33 \% *$ & $1.70 \% * *$ \\
\hline \multicolumn{4}{|l|}{ Individual income (reference group: more than 7,001} \\
\hline \multicolumn{4}{|l|}{ EEK per month) } \\
\hline Less than 7,000 EEK per month & & & -.25 \\
\hline \multicolumn{4}{|l|}{ Employment status (reference group: Working) } \\
\hline Full-time, non-working student & & & -.42 \\
\hline Other & & & -1.14 \\
\hline \multicolumn{4}{|l|}{ Highest level of completed education (reference } \\
\hline \multicolumn{4}{|l|}{ group: Higher) } \\
\hline Basic or less & & & $-1.77 *$ \\
\hline General secondary & & & $-1.63 *$ \\
\hline Vocational or professional secondary & & & $-2.26 * *$ \\
\hline \multicolumn{4}{|l|}{ Marital status (reference group: Single) } \\
\hline Married or living with a partner & & & -.88 \\
\hline \multicolumn{4}{|l|}{ Having children (reference group: No) } \\
\hline Yes & & & -.35 \\
\hline \multirow{2}{*}{\multicolumn{4}{|c|}{$\begin{array}{l}\text { Parents' highest level of completed education } \\
\text { (reference group: Higher) }\end{array}$}} \\
\hline \\
\hline & & & \\
\hline General secondary & & & -.77 \\
\hline Vocational or professional secondary & & & -.66 \\
\hline \multicolumn{4}{|l|}{ Parental highest occupational group (reference group: } \\
\hline \multicolumn{4}{|l|}{ Unskilled blue-collar) } \\
\hline Manager, professional & & & -.58 \\
\hline Lower non-manual & & & -.92 \\
\hline Skilled blue-collar & & & -.81 \\
\hline
\end{tabular}


Table 7.5 continued

\begin{tabular}{lccc}
\hline & Model 1 & Model 2 & Model 3 \\
\hline Constant & .58 & 20.74 & 22.28 \\
Pseudo R square & .02 & .21 & .34 \\
Number of cases & 275 & 275 & 275
\end{tabular}

* $* *$ Effect significant at $p<0.01$

$\approx *$ Effect significant at $p<0.05$

*Effect significant at $p<0.10$

Source: Own calculations based on TIES

residential behaviour patterns created by the Soviet socialist housing system. As previously mentioned, traditionally there are more Estonians living in detached/single-family houses often located in ethnically homogeneous areas, and more Russians living in flats, in either the ethnically heterogeneous areas or large-scale housing districts dominated by Russian-speaking inhabitants. This is an explicit pattern revealing the past legacies of the native Estonian residential culture and that of the Soviet housing policy, intertwining with modern institutional practices and individual housing strategies of people of distinct ethnic origin.

We may conclude, on the basis of regression models, that ethnic differences in spatial conditions are present in young households residing on their own: Russians tend to have a greater probability of living in flats at a higher density. However, the significance of ethnicity decreases when the influence of other residential and socio-economic factors are taken into account.

\subsection{Ethnically segregated neighbourhoods and neighbourhood satisfaction}

The quality of housing is shaped not only by individual resources and preferences evoking particular individual housing strategies but also by the structural context of conduct in the field constraining or enabling the actors' choices. In this respect, the local composition of housing stock in terms of its technical, functional or aesthetic qualities, for example, as well as market conditions and ownership structure are important factors that influence the formation of differentiated housing conditions. Residents' satisfaction, however, influences their evaluation of these conditions, as well as the social component of a residential population, the neighbours' behaviour and the relational aspects of residing in a particular place. Hence, the formation of residential satisfaction is associated with a particular place attachment or a sense of home constructed upon recognition of the presence of valued qualities, as has 
been argued elsewhere (Paadam 2003). There is also a highlighted duality of a relationship shaping between agencies and structural contexts, as well as the distinct nature of socio-physical relations identified in all spatial scales of residence: flats, houses or blocks and the neighbourhood in general.

A particular characteristic of the Estonian urban housing and residential neighbourhoods is that, today, they are mainly composed of blocks rather than single-family houses. Therefore, the majority of the urban population lives in flats: 94 per cent of the population in Tallinn, 83 per cent in Kohtla-Järve and 95 per cent in Jõhvi (Statistics Estonia). However, the city of Tallinn presents the case of the most heterogeneous circumstances, both in terms of physical structures and ethnic compositions of its residential areas (see Sokolova in this volume). In three districts out of eight, the share of Russian people is higher than the average for Tallinn. Their higher concentration is denoted, respectively, in the Soviet era large-scale housing districts of Lasnamäe and Haabersti, as well as in an old, previously predominantly working-class and lower middle-class area of Põhja-Tallinn, with relatively heterogeneous types of residential buildings. Strong Estonian dominance is evident in districts composed mainly of small-scale housing (single-family houses, semi-detached houses and smaller blocks) in the districts of Normme, Pirita and Kristiine, as well as in the Central district, with the highest concentration of diverse residential buildings of distinct age and architectural design (Tallinn City Government 2008).

However, while analysing the neighbourhood satisfaction of secondgeneration Russians, we are relying on the respondents' subjective estimations of their neighbourhoods. Table 7.6 shows that these subjective estimations correspond well with the actual ethnic compositions of the urban neighbourhoods in the ethnically heterogeneous city of Tallinn and with the Russian-dominated neighbourhoods in the towns of Jõhvi and Kohtla-Järve.

As argued earlier in this chapter, ethnicity-based neighbourhood poverty concentration is not clearly demarcated in Estonian society. Concerning the subjective perceptions of neighbourhood characteristics, analysis of the TIES database shows that compared to Estonians, second-generation Russians are more positively disposed towards expressing higher satisfaction with the quality of their neighbourhood. They tend to identify these neighbourhoods as upper- or middle-class neighbourhoods and 95 per cent of Russian and 85 per cent of Estonian respondents consider themselves to be living in these areas. 75 per cent of Russian and 62 per cent of Estonian respondents believe that the liveability of their neighbourhood is sustainable in the future. In addition, the neighbourhood satisfaction index was higher for the Russian respondents, 67 per cent said they were satisfied, while only 48 per 
Table 7.6 Estimations on the ethnic composition of the neighbourhood (in \%)

\begin{tabular}{lcccccc}
\hline & $\begin{array}{c}\text { Tallinn: } \\
\text { Russian }\end{array}$ & $\begin{array}{l}\text { Tallinn: } \\
\text { Estonian }\end{array}$ & $\begin{array}{l}\text { Jöhvi and } \\
\text { Kohtla-järve: } \\
\text { Russian }\end{array}$ & $\begin{array}{l}\text { Jõhvi and } \\
\text { Kohtla-Järve: } \\
\text { Estonian }\end{array}$ & Total \\
\hline $\begin{array}{l}\text { The inhabitants are mostly of the } \\
\quad \text { same ethnicity }\end{array}$ & 9 & 23 & 53 & 6 & 25 \\
$\begin{array}{l}\text { Around } 75 \% \text { of the inhabitants } \\
\quad \text { are of the same ethnicity }\end{array}$ & 15 & 21 & 25 & 9 & 18 \\
$\begin{array}{l}\text { Half of the inhabitants are of the } \\
\quad \text { same ethnicity }\end{array}$ & 60 & 45 & 18 & 24 & 35 \\
$\begin{array}{l}\text { Around 25\% of the inhabitants } \\
\quad \text { are of the same ethnicity }\end{array}$ & 15 & 9 & 4 & 42 & 16 \\
$\begin{array}{l}\text { Almost none of the inhabitants } \\
\quad \text { are of the same ethnicity }\end{array}$ & 2 & 0 & 0 & 20 & 5 \\
\begin{tabular}{l} 
Total \\
\hline
\end{tabular} & 100 & 100 & 100 & 100 & 100 \\
\hline
\end{tabular}

Source: Own calculations based on TIES

cent of Estonians had the same level of index value. We calculated a logistic regression model, where the ethnic background remained significant also after taking into account the influence of other residential and socio-economic factors. We then calculated different models for the Russian residents and Estonians in order to analyse the different bases for the formation of neighbourhood satisfaction in these groups. Table 7.7 presents these models.

The models reveal that the probabilities of having neighbourhood satisfaction are lower in Tallinn, compared to Kohtla-Järve and Jõhvi, for respondents from both ethnic groups. However, it appears that for Estonians, the housing type is also significant: those living in family houses have higher probabilities of being satisfied with their neighbourhood. When it comes to Estonians, past migration to the present place of residence from other parts of Estonia - mainly from smaller towns or rural areas adjacent to Tallinn - increases the likelihood of being satisfied with the present neighbourhood. Living within the same ethnic group is the most significant factor to increase the probability of gaining higher neighbourhood satisfaction amongst the Estonian respondents. For the Russian respondents the same factor has no statistical significance. Previous research in Estonia, as well as elsewhere, has referred to the significance of early residential experiences in the formation of housing preferences (Leemet \& Paadam 2002; Paadam 2003; Kulu 2003b; Mazanti 2007; Ærø 2006). Hence, the less significant influence of ethnic composition on the neighbourhood satisfaction of Russian residents can be interpreted as a reflection of their childhood residential experiences, gained predominantly in urban blocks of either the ethnically more heterogeneous neighbourhoods or those of strong 
Table 7.7 Neighbourhood satisfaction (own households): Logistic regression models

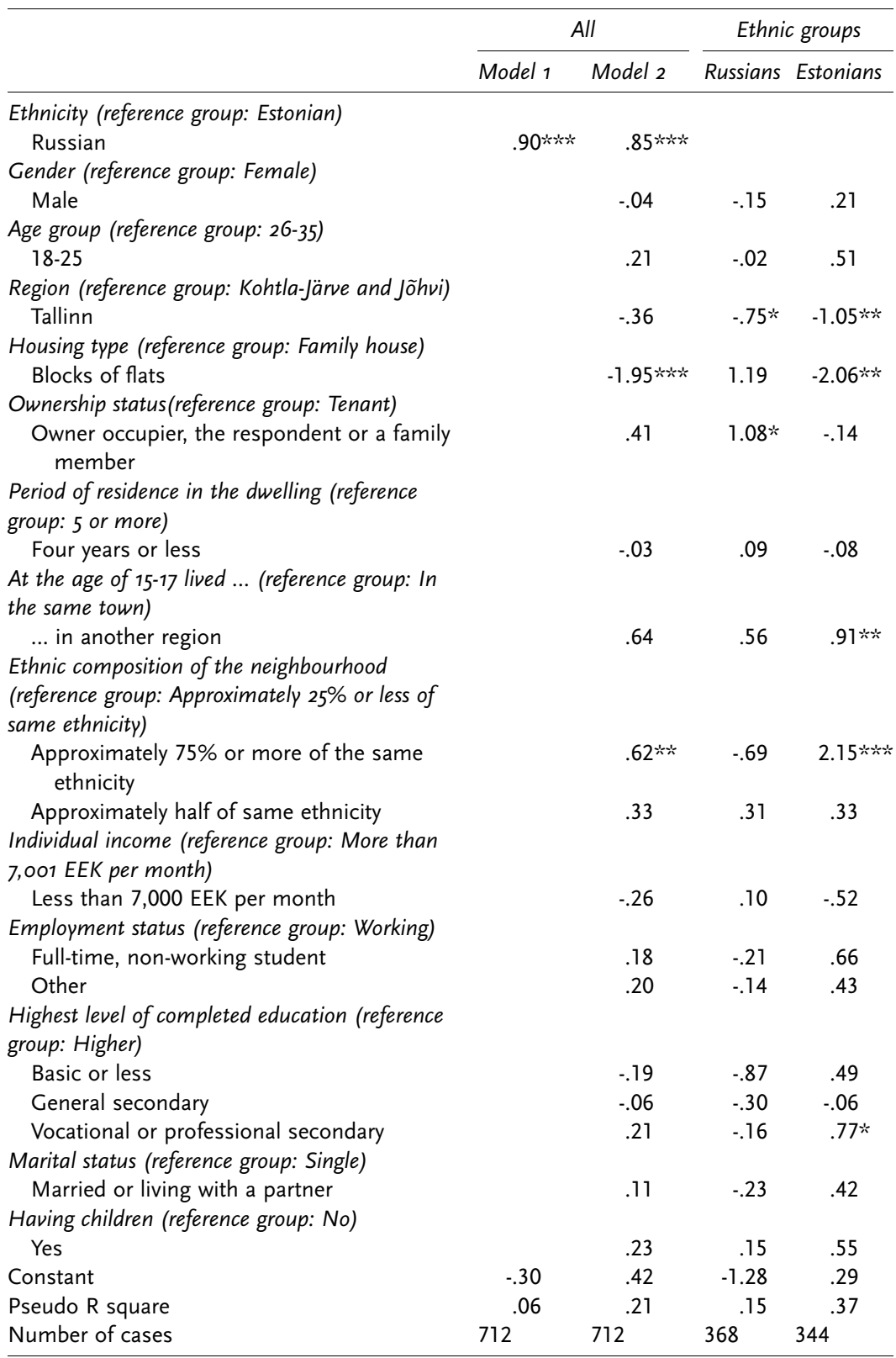

$* * *$ Effect significant at $p<0.01$

$* *$ Effect significant at $p<0.05$

*Effect significant at $p<0.10$

Source: Own calculations based on TIES 
Russian dominance. Both cases favoured the relatively easy adaptation of the first post-war immigrant population in the past, because they exerted particular symbolic power in residential relations and over the local residential culture. This, in addition to their generally favoured position in the Soviet ideological context, had partly been supported by their privileged position in accessing the public housing distribution system. The neighbourhoods of predominantly family houses represent the cultural legacy, the nature of a particular residential culture, which is highly valued by Estonians who form the majority group of these ethnically homogeneous areas. That said, the situation is gradually changing, as increasing numbers of Russian people are able to purchase family houses (Ojamäe \& Paadam 2009).

\subsection{Conclusions}

Ethnic distinctions seem to continue advancing in the Estonian housing field when observed by housing types. This reveals a certain persistency of cultural models that characterise different ethnic groups and link the first and second generations by repeated housing behaviour patterns: more Russians continue living in flats, often in circumstances of higher density, and more Estonians continue living in family houses. The comparison of tenure statuses reveals no distinctions between the ethnic groups of young Russians and Estonians, although the orientation of both groups towards rental markets rather than owner-occupation distinguishes them from the currently dominant housing behaviour pattern.

Ethnic segregation is characteristic of urban residential, as well as regional, development in Estonia. However, in contrast to patterns known from Western cities and especially the US, Estonian ethnic minorities present mixed groups of residents without a necessarily high concentration of low capacities in the neighbourhood. Striking contrasts forming spatially between different strata are apparent only at the top of the scale as 'pockets of wealth' rather than 'pockets of poverty'. Modern ethnic segregation patterns can be traced back to the migration and housing policies that characterised the previous Soviet socialist social system, which facilitated the formation of the specific nature of housing relations, allocation and distribution practices, the construction and aesthetic qualities of the built residential structures, the social composition of residents in neighbourhoods and spatial separation of ethnicities. Although a reproduction of respective segregation patterns has been observed, more recent data (ibid.) suggest that the differences in housing preferences and/or opportunities are gradually decreasing. 


\section{References}

Aalbers, M. \& R. Deurloo (2003), 'Concentrated and condemned? Residential patterns of immigrants from industrial and non-industrial countries in Amsterdam', Housing, Theory and Society 20 (4): 197-208.

Arbaci, S. (2007), 'Ethnic segregation, housing systems and welfare regimes in Europe', European Journal of Housing Policy 7 (4): 40I-433.

Ærø, T. (2006), 'Residential choice from a lifestyle perspective', Housing, Theory and Society 23 (2): 109-I30.

Bruns, D. (I993), Tallinn. Linnaehituslik kujunemine. Tallinn: Valgus.

Eesti arvudes 1920-1935 (1937), Tallinn: Eesti Statistika Keskbüroo.

Fisher, L.M. \& A.J. Jaffe (2000), 'Restitution in transition countries', Journal of Housing and the Built Environment 15: 233-248.

Gentile, M. \& T. Tammaru (2006), 'Housing and ethnicity in the post-Soviet city: Ust'Kamenogorsk, Kazakhstan', Urban Studies 43 (I0): I757-I778.

Häußermann, H. \& I. Oswald (200I), 'Wohnungseigentum? Nicht geschenkt! Zur wohnungsprivatisierung in Russland', Zeitschrift für Soziologie 30 (I): 65-78.

Hegedüs, J. \& I. Tosics (I998), 'Transition and social sustainability in post-socialist urban systems. New challenges in the restructuring process of Central-East European metropoles', paper presented at the ENHR conference Housing Futures: Renewal, Sustainability and Innovation, Cardiff, 7-II September 1998.

Jaffe, A. (1995), 'Property rights and privatisation in the Baltic countries', Building and housing, Nord (Series) 25. Copenhagen: Nordic Council of Ministers.

Kemeny, J. (1992), Housing and Social Theory. London and New York: Routledge.

Kontuly, T. \& T. Tammaru (2006), 'Population subgroups responsible for new urbanization and suburbanization in Estonia', European Urban and Regional Studies I3 (4): 319336.

Kulu, H. (2003a), 'Housing differences in the late Soviet city: The case of Tartu, Estonia', International Journal of Urban and Regional Research 27 (2): 897-9II

Kulu, H. (2003b), 'Residence and migration in post-war Soviet Estonia: the case of Russian-born Estonians', Tijdschrift voor Economische en Sociale Geografie 94 (5): 576588.

Kulu, H. \& T. Tammaru (2003), 'Housing and ethnicity in Soviet Tartu', Yearbook of Population Research in Finland 39: II9-I40.

Ladanyi, J. (I995), 'Market, state and informal networks in the growth of private housing in Hungary', in R. Forrest \& A. Murie (eds.), Housing and family wealth: Comparative international perspectives, 202-2I4. London and New York: Routledge.

Leemet, A. \& K. Paadam (2002), 'Case Kadriorg', in K. Paadam (ed.), Changing neighbourhoods in Tallinn: Mustamäe, Kalamaja, Kadriorg, 78-Io8. Tallinn: TTU Press.

Kursis, J. (I999), Housing privatisation in the Baltic states: Housing development and management. Lund: Lund University.

Malheiros, J. (2002), 'Ethni-cities: Residential patterns in the Northern European and Mediterranean metropolises - implications for policy design', International Journal of Population Geography 8: 107-I34.

Mandic, S. \& D. Clapham (I996), 'The meaning of home ownership in the transition from socialism: the example of Slovenia', Urban Studies 33 (I): 83-97.

Mazanti, B. (2007), 'Choosing residence, community and neighbours: Theorizing families' motives for moving', Geografiska Annaler 89 B (I): 53-68.

Musterd, S. \& R. Deurloo (2002), 'Unstable immigrant concentrations in Amsterdam: spatial segregation and integration of newcomers', Housing Studies I7 (3): 487-503.

Ojamäe, L. (forthcoming), 'Making choices in the housing market: social construction of housing value', Research in Economics and Business. 
Ojamäe, L. \& K. Paadam (2009), 'Kodu ja eluase', in L. Hansson (ed.), Argielu Eestis 19852008, 93-II3.Tallinn: TPU Press.

Omanikele tagastatud majades elavate ü̈̈rnike probleemid ja nende lahendusteed (Problems and solutions for the tenants in restituted housing), (1998), Tallinn: Eesti Konjunktuuriinstituut.

Org, A. (1989), 'Korteriolud', in M. Pavelson (ed.), Tallinna taastootmismehhanism ja arengustrateegia, 22-49. Tallinn: Tallinna Linnauurimise Instituut.

Özüekren, A.S. \& R. van Kempen (2002), 'Housing careers of minority ethnic groups: Experiences, explanations and prospects', Housing Studies I7 (3): 365-379.

Özüekren, A.S. \& R. van Kempen (2003), 'Editors' introduction: Dynamics and diversity. housing careers and segregation of minority ethnic groups', Housing, Theory and Society 20 (4): I62-I7I.

Paadam, K. (2009), 'Countries in transition: The Baltic countries', in A. Holt-Jensen \& E. Pollock (eds.), Urban sustainability and governance: New challenges in Nordic-Baltic housing policies. I7I-I77. New York: Nova Science Publishers.

Paadam, K. (2003), Constructing residence as home: Homeowners and their housing histories. Tallinn: TPU Press.

Paadam, K. (ed.) (I995), Tallinna linnaelanike osalus linna arengu kavandamises. Lõpparuanne. Tallinn: Tallinna Linnauuringute Instituut.

Paadam, K. (1996), 'Residents of Tallinn: Views on housing environment', in Large-scale housing areas in the Baltic countries: Report from the expert group meeting, LCHS, SCBR, 9-II, Lund: Lund University.

Pavelson, M. (ed.) (1989), Tallinna taastootmismehhanism ja arengustrateegia. Tallinn: Tallinna Linnauurimise Instituut.

Pavelson, M. (ed.) (2000), Eluasemestrateegia Tallinnas. Tallinn: Linnauuringute Instituut.

Rahva demograafiline koosseis ja korteriolud Eestis. 1922a. üldrahvalugemise andmed. Vihk 1 (Demographic composition and housing conditions in Estonia. The census data from 1922) (I924), Tallinn: Riigi Statistika Keskbüroo.

Ruoppila, S. (2006), 'Residential differentiation, housing policy and urban planning in the transformation from state socialism to a market economy. The case of Tallinn', Centre for Urban and Regional Studies Publications A33. Espoo: Helsinki University of Technology.

Schönwälder, K. \& J. Söhn (2009), 'Immigrant settlement structures in Germany: General patterns and urban levels of concentration of major groups', Urban Studies 46 (7): I439-I460.

Social Trends 4 (2007), Tallinn: Statistics Estonia.

Social Trends 2 (200I), Tallinn: Statistics Estonia.

Szelenyi, I. \& S. Szelenyi (I995), 'Circulation or reproduction of elites during the postcommunist transformation in Eastern Europe', Theory and Society 24: 615-638.

Tallinn City Government (2008), Tallinn arvudes 2007. www.tallinn.ee/g2677540983. Accessed I4 March 2009.

Teixeira, C. (2007), 'Residential experiences and the culture of suburbanization: A case study of Portuguese homebuyers in Missisauga', Housing Studies 22 (4): 495-521.

Teixeira, C. \& R.A. Murdie (I997), 'The role of ethnic real estate agents in the residential relocation process: A case study of Portuguese homebuyers in suburban Toronto', Urban Geography I8: 497-520.

Tomlins, R., M.R.D. Johnson \& D. Owen (2002), 'The resource of ethnicity in the housing careers and preferences of the Vietnamese communities in London', Housing Studies I7 (3): 505-519.

Tomson, L. (2004). 'Kodu ja eluase', in L. Hansson (ed.), Valikud ja võimalused: Argielu Eestis aastatel 1993-2003, 63-77. Tallinn: TPU Press. 
Van Ham, M. \& P. Feijten (2008), 'Who wants to leave the neighbourhood? The effect of being different from the neighbourhood population on wishes to move', Environment and Planning A 40: II5I-II70. 



\title{
8 Contact and crisis in interethnic relations
}

\author{
Jennie Schulze
}

\subsection{Introduction}

Interethnic relations in Estonian society have been the subject of a large body of academic literature. These works have progressed from predicting the outbreak of violence between ethnic groups in the early I990s to explaining Estonia as a perplexing case of non-violence (see Barrington 1995; Brubaker 1998; Chin \& Kaiser 1996; King \& Melvin I999; Laitin 1998; Melvin I995; Pettai \& Hallik 2002; Smith I996, I999; Vetik 200I). The peaceful nature of interethnic relations was disrupted by the violent riots that broke out in Tallinn in April 2007, following the removal of the Bronze Soldier statue, a Soviet World War II memorial, from downtown Tallinn. In the two nights of rioting, on 26 and 27 April, over a hundred people were injured, one man was killed and close to 900 were taken into custody or detained for questioning. ${ }^{\mathrm{I}}$ The riots were the first instance of large-scale violence since Estonia gained its independence. While the majority of the rioters were ethnic Russians, ethnic Estonians did join in the trouble and looting. Nevertheless, there was a clear interethnic conflict dimension to the crisis. The events preceding the crisis, including conflicts between Estonians and Russians at the site in previous years, as well as the government's handling of the statue's removal, produced interethnic tensions in Estonian society. Sociological studies carried out in the wake of the crisis demonstrate its profoundly negative effect on interethnic relations in Estonian society. The crisis has reawakened interest in interethnic relations and tolerance in Estonian society and has sparked a reassessment of the approach taken toward integration by the Estonian government (Ehala 2009; Korts 2009; Laristin \& Vihalemm 2008).

The outbreak of violence in 2007 led to criticism of government integration policies. In response to pressure from the international community, particularly European institutions, the Estonian government developed a national strategy for minority integration (2000-2007). Both the integration programme (2000-2007) and its successor (2008-2013) have prioritised Estonian language learning among the Russian minority in the hopes of reducing the number of stateless persons, over the need to cultivate tolerant attitudes among ethnic groups (Korts 2009: 
I22). Recent studies have shown divergent attitudes between minority and majority groups with respect to their expectations of integration (Lauristin \& Vihalemm 2008). While ethnic Estonians expect the Russian minority to adapt to majority culture and therefore favour institutional solutions, such as language acquisition and school reform, the Russian minority favours a focus on cultivating multicultural attitudes in society through increasing tolerance, participation and recognition (ibid). The Bronze Soldier crisis was a wake-up call for some Estonian elites that the focus on institutional solutions, such as language and citizenship, is not enough to establish an integrated society or peaceful relations among majority and minority groups (Schulze 20I0).

After gaining independence in I99I, Estonian elites adopted a nation-state model of state building, which aims to create territorially sovereign, culturally homogenous nation-states (Csergo 2007: 3I). A nation-state is a 'state which identifies itself in terms of one specific nation whose people are not seen simply as "subjects" of the sovereign but as a horizontally bonded society to whom the state in a sense belongs' (Hastings I997: 3; see also Barrington I997; Connor I994). In order to ensure that their state belonged to the ethnic majority, Estonian elites developed citizenship, language and education policies that protected and privileged the culture of the ethnic majority, at the expense of the large Russian-speaking minority (Aalto 2003; Aasland \& Flotten 200I; Brubaker i996).

The restorationist approach to the state denounced the Soviet occupation as illegal and established legal continuity with the Estonian state of the interwar period (Galbreath 2005; Galezis 2000). As a result, automatic citizenship was granted only to those persons who held citizenship in I940 and their descendants, while all other permanent residents were forced to naturalise. Several studies have argued that this approach to citizenship created a second-class society composed almost entirely of Russians and rendered large segments of the population unsure of their identity (Kelley 2004; Barrington I995; Commercio 2004). This nationalising approach to state building has fuelled perceptions of discrimination against Russians and has reinforced ethnic divisions between Estonians and Russians along linguistic, religious, historical and cultural lines (Petersoo 2007: I24; see also Barrington I995; Kolstoe I996, 2002).

The spatial separation of the two ethnic communities further reinforces these divisions. The fact that the majority of Russians live in IdaVirumaa County and are spatially separated from the majority of Estonians has not encouraged mutual understanding or integration between the two communities (see Sokolova in this volume). In addition, the parallel system of Estonian and Russian language education, inherited from the Soviet period, reduces the opportunities available for 
building bridges between ethnic communities (see Lindemann \& Saar in this volume).

Finally, Russia has aggravated interethnic tensions by pressuring the Estonian government repeatedly throughout the I990s to adopt more inclusive minority policies through a variety of mechanisms. These have included military pressure, economic sanctions, disinformation campaigns, citizenship policy and the use of international institutions as platforms for levelling accusations of discrimination against the Estonian government (Brubaker 1998; Bugajski 2004; Ehin \& Berg 2009; King \& Melvin 2000; Melvin I995; Simonsen 200I). Russia's activism aggravates historical legacies, which produces defensive reactions among Estonian elites and aggravates interethnic tensions in Estonian society in ways that work against integration processes (Schulze 20IO). This combination of nationalising policies, ethnic separation and kinstate activism create a situation that is ripe for interethnic conflict and violence (Brubaker I998; Hallik \& Pettai 2002; Melvin I999).

However, until the events of April 2007, relations between ethnic Estonians and ethnic Russians had been remarkably peaceful. The Baltic Barometer studies conducted throughout the I990s, report a steady decline in the possibility of interethnic violence. In 1993, 69 per cent of Estonians viewed ethnic conflict as a possibility, whereas by 2004 only 7 per cent viewed it as a possibility. While 38 per cent of ethnic Russians viewed ethnic conflict as a possibility in I995, only I per cent viewed it as possibility in $2004 .{ }^{2}$ The 2005 Integration Monitoring in Estonia found that the perception of threat or danger between ethnic Estonians and ethnic Russians had been steadily decreasing. Whereas in 1999, two thirds of ethnic Estonians considered ethnic Russians to be a danger to Estonian national identity, in 2005 , only I 6 per cent of ethnic Estonians felt this way. The 2005 Monitoring also reported that only a very small percentage of respondents from both ethnicities experienced conflicts or hostility on ethnic grounds (Vetik, Hallik, Kruusvall, Pavelson, Pettai \& Proos 2006).

Explanations for the peaceful nature of interethnic relations have alternated between macro-level institutionalist theories and micro-level rationalist accounts. Several studies credit the role of the European Union accession process in taming nationalist sentiments and promoting interethnic toleration in candidate countries (Cooley 2003; Galezis 2000; Galbreath 2005; Kelley 2004; Schimmelfinning 2002; Vachudova 2005). In order to prevent a situation similar to the violent ethnic conflicts that occurred in the former Yugoslav republics, European institutions, particularly the Council of Europe (CoE), the Organisation for Security and Cooperation (OSCE) and the EU, developed a number of conventions aimed at protecting the rights of ethnic minorities in member states. In addition, the protection of minorities was also enshrined 
in the Copenhagen Criteria for EU membership (Brosig 2006). Through the politics of EU membership conditionality, European institutions effectively pressured the Estonian government to make changes to its citizenship and language policies in order to make them compatible with international minority rights standards (Galbreath 2005; Galezis 2000; Kelley 2004).

Other studies point to the role of domestic politics in establishing peace and stability between ethnic groups. Hallik and Pettai (2002: 524) argue that the model of ethnic control, instituted by the Estonian political community over the Russian minority, paradoxically ensured the stability of interethnic relations as opposed to encouraging resistance and conflict. Utilising Ian Lustick's (I979, I980) model of ethnic control, they argue that the restorationist approach to state building contributed to peaceful interethnic relations in three ways. It led to the segmentation of the Russian minority, while the transition to the market economy increased the dependence of the Russian minority on the Estonian majority. Finally, the co-optation of Russian leaders by the Estonian political elite helped to ensure peaceful relations between ethnic groups.

At the micro level, Laitin (1998) has attributed the lack of interethnic violence in Estonia to the increasing willingness of the Russian minority to adapt to Estonian cultural norms. His 'tipping model' of identity shift is predicated on the notion that individuals are the agents of their own identity construction. The decision of Russians to assimilate by learning the Estonian language is an individual choice. This choice is 'an expected utility calculus which requires that the discounted value of returns to an investment in a foreign language be greater than the upfront costs of learning the language' (Laitin I998: II8). As more and more people learn the titular language, a tipping point or cascade effect occurs, where the rate of assimilation increases as ever more individuals make the choice to learn the titular language. Institutions are only important in determining the payoff structure for learning the titular language.

Through multinomial logistic regression analysis of the TIES survey data, this chapter will contribute to micro-level theories by evaluating the comparative impact of interethnic contact, experiences of discrimination, and the Bronze Soldier crisis on four different measures of interethnic relations in Estonia. Rather than building a general model to explain interethnic attitudes among respondents, this chapter will examine whether these variables matter at all for interethnic relations among Russian and Estonian youth. Focusing on the attitudes of second-generation Russians and young Estonians is particularly important for two reasons. First, the focus of the integration strategy in Estonia has been directed at youth and, therefore, evaluating the attitudes of this group is especially important for evaluating the success of 
the integration programme (see Vetik in this volume). Second, surveys conducted after spring 2007 have shown that the Bronze Soldier crisis has had the greatest impact on the attitudes of the youngest generation from both ethnic groups (Korts \& Vihalemm 2008: III).

The results of the analysis support the findings of conventional wisdom that interethnic contact matters. Interethnic friendship is the most important variable for increasing the likelihood that both Estonians and Russians will view both interethnic relations and the out-group positively. However, more generalised contact, in the form of living in ethnically mixed neighbourhoods, seems to have contradictory effects for ethnic Russians and ethnic Estonians. While living in ethnically mixed neighbourhoods increases the probability of positive views among Russians, it increases the probability of negative views among Estonians. In addition, experiences of discrimination increase the odds that the respondent will have a negative view of interethnic relations. Some minimal support was found for the impact of the Bronze Soldier crisis on interethnic attitudes among Russians; however, the politicisation of the issue and the size of the sample groups may have underestimated the effect of the crisis in the analysis.

\subsection{Theoretical considerations and previous research: The contact thesis and the Bronze Soldier crisis}

The contact hypothesis remains one of the prevailing theories for understanding interethnic relations. The contact hypothesis, which was first elaborated by Watson (I947) and Robin M. Williams (I947) and later specified by Gordon Allport (I954), states: 'contact, particularly close and sustained contact, with members of different cultural groups promotes positive, tolerant attitudes', while 'the absence of such contact is believed to foster stereotyping, prejudice, and ill will toward these groups' (Ellison \& Powers I994: 385). Allport (I954) argues that four conditions are necessary for intergroup contact to have a positive impact: equal group status within the situation; common goals; intergroup cooperation; and the support of authorities, law or custom (Pettigrew I998: 66). While Allport (I954) does not argue that intergroup contact would in itself produce better relations between groups, in the absence of these specified conditions, several studies across a variety of cases have found support for the contact thesis, even in conditions that are less than ideal (Pettigrew i998).

The contact thesis has been elaborated by several studies that specify not only when intergroup contact will lead to more positive attitudes, but the mechanisms by which contact leads to attitudinal change. Pettigrew (I998) argues that there are four primary mechanisms 
governing the way in which intergroup contact affects attitudes. These four mechanisms, which have found support in a number of studies, include learning about the out-group (Gardiner 1972; Ellison \& Powers I994; Stephan \& Stephan I984; Weldon, Carlson, Rissman, Slobbodin \& Triandis I975); behavioural change (Aaronson \& Patnoe I997; Jackman \& Crane i986); affective ties (Amir i976; Pettigrew i997a, b); and in-group reappraisal (Wilner, Rosabelle, Walkley \& Cook I955). Further studies have argued that personal contact can only lead to generalised attitudes toward the out-group when group membership is salient (Hewstone \& Brown I986; Pettigrew I998). Because it is unlikely that all of these conditions will be met in the real world, some studies have focused on whether contact itself fosters positive attitudes more generally, even in the absence of some of these conditions (Ellison \& Powers I994; Pettigrew \& Tropp 2006; \& Sigelman \& Welch I993).

Both the frequency of interethnic contact and the depth of the contact have an impact on interethnic attitudes. Several studies have noted that friendship is more likely to foster positive attitudes toward interethnic relations than more generalised contact (Ellison \& Powers I994; Hayes \& Dowds 2006; Pettigrew I997a, b; Pettigrew \& Meertens I995). While living in a mixed neighbourhood may make the possibility for intergroup friendship more likely, friendship is still the strongest predictor of attitudes, precisely because friendship is likely to involve all four mechanisms noted above (Pettigrew I998: 72, 76). Finally, demographic factors, such as the likelihood of contact, as well as the hierarchical structure of intergroup relations, may result in contact having different effects for each group (Ellison \& Powers I994). It is also important to note that negative experiences can also affect attitudes and that while frequent contact generally increases positive attitudes toward the outgroup, bad experiences during this contact can increase negative attitudes toward the out-group (Pettigrew I998: 7I).

The validity of the contact hypothesis is robust. Empirical studies, which have reported positive findings for the contact hypothesis, include research into interracial attitudes in the United States (Ellison \& Powers I994; Smith I994), attitudes toward immigrants in Northern Ireland (Hayes \& Dowds 2006) and relations between Israeli and Palestinian groups (Mi'Ari I999). More recently, the contact hypothesis has also been applied to the study of interethnic relations in Estonia (Korts 2009). The results of the study find support for the contact thesis, namely that more open attitudes towards the other ethnic group are strongly linked to higher levels of interethnic contact (ibid.: I24).

While interethnic contact has reportedly had a positive effect on interethnic relations in Estonia, sociological studies conducted in the wake of the Bronze Soldier crisis have pointed to a deterioration of interethnic relations between Estonians and Russians. As Ehala (2009) argues, 
a comparison of identity orientations among Estonians and Russophones in 2002 (Pettai 2002) and in the summer of 2007 (Lauristin 2008), reveals a sharpening of ethnic opposition between Estonians and Russophones (Ehala 2009: I53). The number of Estonians manifesting integrative attitudes has decreased from 53 per cent to 36 per cent. The proportion of those who accept the presence of Russophones but do not want to have contacts with them rose considerably. The number in this category increased from 28 per cent in 2002 to as many as 40 per cent in 2007 (ibid. citing Lauristin 2008; Pettai 2002). Among Russophones, the number of those manifesting integrative attitudes and values has dropped from 46 per cent in 2002 to 27 per cent in 2008, and the number of those who cooperate on pragmatic grounds but are disillusioned has risen from 20 per cent to 33 per cent (ibid.). The Russophones 'who previously had sincerely believed in Estonian democracy and justice have been deeply hurt' by the government action and the reactions of large sections of Estonians to the 'Bronze Night' (Ehala 2009: I54 citing Belobrovtsev 2008: I23). The possibility of Russophones being mobilised into an oppositional position towards Estonians has been stressed by a number of researchers (Ehala 2009:I54 citing Lobjakas 2008; Vetik 2008).

Korts (2009) finds that interethnic relations have deteriorated following the Bronze Soldier crisis. An analysis of attitudes among both Estonian and Russian youth, based on the survey Ethnic Relations and Challenges to the Integration Policy after the Bronze Soldier crisis and an accompanying qualitative study, shows that both groups perceive a lack of respect from the other, and that these feelings were reinforced by the Bronze Soldier troubles (Korts 2009: I35). The study also reveals a generalised feeling of alienation from Estonian society among young Russians. These findings have relevance for Brubaker's argument that researchers should be wary of reifying groups in their studies and that ethnic groups and nations should be treated not as 'entities' but as 'contingent events' of collective solidarity (Brubaker I996: I6, 2004: II). This chapter examines the extent to which the Bronze Soldier crisis triggered 'groupness', or solidarity, among Estonians and Russians with respect to their views on interethnic relations.

\subsection{Data and methods}

Using multinomial logistic regression models, this chapter will test the following hypotheses: I) contact with the other ethnic group, but especially close contact in the form of friendship, should increase the odds that respondents will have a positive view of interethnic relations; 2) discrimination on the basis of ethnicity should increase the likelihood 
that respondents will view interethnic attitudes negatively; and 3) being interviewed before the Bronze Soldier riots on 26 April should increase the likelihood of viewing interethnic relations positively.

We have used four indicators of interethnic relations, each measuring different aspects of the phenomenon. The first indicator asks respondents to evaluate the degree to which relations between ethnic Estonians and ethnic Russians are friendly using a three-point scale: 'not friendly', 'indifferent' and 'friendly'. The second indicator asks respondents how relations between ethnic groups have changed in the last five years, again using a three-point scale: 'less friendly', 'same' and 'more friendly'. The third indicator asks respondents about the degree of threat to their own culture as a result of living together with people from the other ethnic group. A three-point scale - 'threatening', 'indifferent' and 'enriching' - is used to measure threat perceptions. Finally, affinity towards the out-group is measured by asking respondents to express the warmness they feel toward other groups in degrees Celsius ranging from o-Ioo degrees. The range 0-45 degrees are defined as 'cool' feelings towards the 'out-group,' the range 46-55 degrees indicate neutral or indifferent feelings, while the range 56-100 degrees demarcate warm feelings.

Variables included into the four models are friendship, neighbourhood composition, experienced discrimination and timing of the interview. The models also take into account age, group and city. Age is coded into a two-category variable, with a younger age group consisting of respondents aged I8-26 and an older age group aged 27-35. City is treated as a categorical variable, with the two cities being Tallinn and Kohtla-Järve. Sex is typically included in models that explain interethnic relations; however, it was not included here, as sex was not significant in likelihood ratio tests for any of the four models.

Following previous studies, two measures of interethnic contact are used. The first measure, representing more generalised interethnic contact, is the percentage of the other ethnic group living in a respondent's own neighbourhood. Ethnically unmixed neighbourhoods are those in which more than 75 per cent of the inhabitants belong to the respondent's own ethnic group. Ethnically mixed neighbourhoods are those in which less than 75 per cent of inhabitants belong to the respondents own ethnic group. The second measure of interethnic contact is friendship. Respondents were asked how many of their current friends are of the other ethnic group and responses are coded 'none' or 'some'.

A question regarding whether the respondent has ever been treated unfairly based on ethnicity, either as a child or later in life, measures discrimination. Responses are coded as 'yes' and 'no'. The vast majority of both ethnic Russian and Estonian respondents, over 70 per cent for 
each group, reported that they had not experienced discrimination on the basis of ethnicity.

In order to examine the impact of the Bronze Soldier crisis on respondents' attitudes toward interethnic relations, Estonian and Russian respondents are split into two groups: those interviewed before 26 April 2007 and those interviewed after. It is expected that respondents in Tallinn will be more affected by the crisis, given that the riots occurred in the city; however, the group sizes for Russians and Estonians in Tallinn and Kohtla-Järve before and after the crisis are not equal. Therefore, the results of the regression analysis should be interpreted cautiously.

Ellison and Powers (I994) argue that where interethnic relations are hierarchical, as is the case in Estonia, the contact hypothesis may have different effects for each group. Because responses regarding interethnic relations differ significantly among Estonian and Russian respondents for all four indicators of interethnic relations, separate models for Estonian and Russian respondents are run for each of the four indicators of interethnic attitudes.

\subsubsection{Model 1: Evaluation of interethnic relations}

The first model tests whether the predictors increase the odds that interethnic relations will be viewed as unfriendly or indifferent, as opposed to friendly. Friendship was significant only for Russian respondents. For Russians, having no Estonian friends, as opposed to having some, increases the odds of viewing interethnic relations as unfriendly

Table 8.1 Multinomial logistic regression model 1

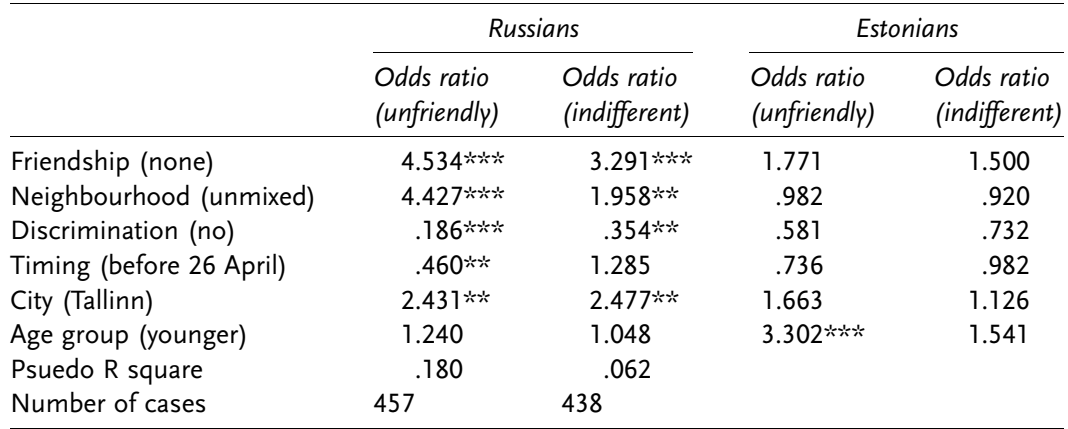

Note: Reference category dependent variable $=$ friendly

$* * *$ Effect significant at $p<.001$

$* *$ Effect significant at $p<.05$

*Effect significant at $p<.10$

Source: Own calculation based on TIES 
fourfold. The odds of viewing interethnic relations indifferently as opposed to friendly, also increases by three times for those having no Estonian friends. This lends support to the contact thesis. The Russian model provides further support for the contact thesis with regard to neighbourhood composition. Living in an ethnically unmixed neighbourhood makes it four times more likely that the respondent will view interethnic relations as unfriendly, and twice as likely that they will view interethnic relations indifferently as opposed to friendly. Those Russians who have never experienced discrimination are less likely to view interethnic relations as unfriendly or indifferent. In addition, Russian respondents living in Tallinn are two and a half times more likely to view interethnic relations as unfriendly or indifferent, as opposed to friendly. Finally, being interviewed before 26 April decreases the odds of viewing interethnic relations as unfriendly. Among Estonians, the only variable that was significant in the likelihood ratio test was age. Being in the younger age group increases the likelihood of viewing interethnic relations as unfriendly by three times.

\subsubsection{Model 2: Change in interethnic relations}

The second model estimates the impact of the predictors on the likelihood that relations between ethnic groups have become less friendly or remained the same as opposed to more friendly in the last five years. For both Russians and Estonians, discrimination, city and the timing of the interview are all significant predictors of responses to this question. In addition, neighbourhood composition is also significant for Russian respondents. For both groups, being interviewed before the crisis

Table 8.2 Multinomial logistic regression model 2

\begin{tabular}{|c|c|c|c|c|}
\hline & \multicolumn{2}{|c|}{ Russians } & \multicolumn{2}{|c|}{ Estonians } \\
\hline & $\begin{array}{l}\text { Odds ratio } \\
\text { (less friendly) }\end{array}$ & $\begin{array}{l}\text { Odds ratio } \\
\text { (same) }\end{array}$ & $\begin{array}{l}\text { Odds ratio } \\
\text { (less friendly) }\end{array}$ & $\begin{array}{l}\text { Odds ratio } \\
\text { (same) }\end{array}$ \\
\hline Friendship (none) & 1.847 & 1.507 & 1.371 & .942 \\
\hline Neighbourhood (unmixed) & $3.011 * *$ & $2.414 * *$ & 1.338 & 1.372 \\
\hline Discrimination (no) & .667 & $1.831 *$ & .957 & $1.749 *$ \\
\hline Timing (before 26 April) & $.378 * *$ & 1.227 & $.229 * * *$ & .491 \\
\hline City (Tallinn) & $2.116 * *$ & 1.151 & $2.378 * *$ & .616 \\
\hline Age Group (younger) & .591 & .792 & 1.326 & .920 \\
\hline Psuedo $\mathrm{R}$ square & .177 & .154 & & \\
\hline Number of cases & 456 & 437 & & \\
\hline
\end{tabular}

Note: Reference category dependent variable $=$ more friendly

$* * *$ Effect significant at $p<.001$

$* *$ Effect significant at $p<.05$

*Effect significant at $p<.10$

Source: Own calculation based on TIES 
decreases the odds of viewing interethnic relations as less friendly as opposed to more friendly. In addition, living in Tallinn increases the likelihood of viewing interethnic relations as less friendly as opposed to more friendly by two times for both Russians and Estonians. For Russians, living in an ethnically unmixed neighbourhood increases the likelihood that respondents would view interethnic relations as being less friendly or the same, providing some support for the contact thesis. However, in this model friendship was not significant for either ethnic group.

\subsubsection{Model 3: Perception of cultural threat}

The third model estimates the impact of the predictors on the likelihood that living together with people of different backgrounds will be viewed as threatening or indifferent to one's own culture, as opposed to enriching. Those Russians with no Estonian friends are almost twice as likely to view living together with other cultures as threatening as opposed to enriching. Having no Estonian friends also increases the odds of being indifferent toward living together with people of different backgrounds. While friendship was not significant for Estonians, living in an unmixed neighbourhood decreases the odds of viewing different cultures as threatening, and living in Tallinn decreases the likelihood of viewing other cultures as indifferent as opposed to friendly. This evidence does not support the contact thesis. For ethnic Estonians, living together with people of other ethnic backgrounds increases the probability that they will view other cultures as threatening.

Table 8.3 Multinomial logistic regression model 3

\begin{tabular}{lccccc}
\hline & \multicolumn{2}{c}{ Russians } & & \multicolumn{2}{c}{ Estonians } \\
\cline { 2 - 3 } \cline { 5 - 6 } & $\begin{array}{l}\text { Odds ratio } \\
\text { (threatening) }\end{array}$ & $\begin{array}{c}\text { Odds ratio } \\
\text { (indifferent) }\end{array}$ & & $\begin{array}{l}\text { Odds ratio } \\
\text { (threatening) }\end{array}$ & $\begin{array}{c}\text { Odds ratio } \\
\text { (indifferent) }\end{array}$ \\
\hline Friendship (none) & $1.817 *$ & $1.742 * * *$ & & .968 & .747 \\
Neighbourhood (unmixed) & .704 & .986 & & $.561 * *$ & .925 \\
Discrimination (no) & .687 & 1.326 & & .736 & .973 \\
Timing (before 26 April) & 1.934 & $.560 * *$ & & .702 & .778 \\
City (Tallinn) & 1.554 & 1.032 & & .708 & $.363 * *$ \\
Age group (younger) & 1.817 & .909 & & 1.574 & 1.741 \\
Psuedo R square & .068 & .087 & & & \\
Number of cases & 455 & 438 & & & \\
\hline
\end{tabular}

Note: Reference category dependent variable = enriching

$* * *$ Effect significant at $p<.001$

$* *$ Effect significant at $p<.05$

*Effect significant at $p<.10$

Source: Own calculation based on TIES 


\subsubsection{Model 4: Feelings of warmth toward other ethnic group}

The final model estimates the impact of the predictors on the odds of viewing the out-group coolly or neutrally as opposed to warmly. For Russians, the predictors were estimated for how warmly they feel toward ethnic Estonians, while for Estonians, the predicators were estimated for how warmly they feel toward Russians living in Estonia. Having friends within the other ethnic group was significant for both Russians and Estonians. For Russians, having no Estonian friends increases, by almost four times, the odds of feeling coolly towards ethnic Estonians as opposed to warmly. For Estonians, having no Russian friends increases the odds of feeling coolly as opposed to warmly toward Russians by more than two and a half times. Having no friends among the out-group also increases the likelihood of feeling neutral, as opposed to warmly, toward the out-group for both Estonians and Russians. Neighbourhood composition was also significant for Estonians with results similar to those in the third model. For Estonians, living in an ethnically unmixed neighbourhood decreases the likelihood of viewing interethnic relations as cool. This is also the only model in which experiences of discrimination affect Estonian respondents. Never experiencing discrimination decreases the odds of viewing the out-group coolly as opposed to warmly. It also decreases the likelihood of feeling neutral, as opposed to warmly, toward Russians. Finally, the timing of the interview had a significant impact on how Russians view Estonians with puzzling results. The results of the analysis show that Russians interviewed before the crisis were two and a half times more likely to view Estonians coolly as opposed to warmly.

Table 8.4 Multinomial logistic regression model 4

\begin{tabular}{lccccc}
\hline & \multicolumn{2}{c}{ Russians } & & \multicolumn{2}{c}{ Estonians } \\
\cline { 2 - 3 } & $\begin{array}{l}\text { Odds ratio } \\
\text { (cool) }\end{array}$ & $\begin{array}{l}\text { Odds ratio } \\
\text { (neutral) }\end{array}$ & & $\begin{array}{l}\text { Odds ratio } \\
\text { (cool) }\end{array}$ & $\begin{array}{c}\text { Odds ratio } \\
\text { (neutral) }\end{array}$ \\
\hline Friendship (none) & $3.901 * * *$ & $1.705 * *$ & & $2.622 * *$ & 1.097 \\
Neighbourhood (unmixed) & 1.569 & 1.370 & & $.380 * *$ & .810 \\
Discrimination (no) & .489 & .758 & & $.453 * *$ & $.658 *$ \\
Timing (before 26 April) & $2.572 * *$ & 1.218 & & .854 & 1.361 \\
City (Tallinn) & 1.625 & 1.357 & & 1.675 & 1.464 \\
Age group (younger) & 1.502 & 1.204 & & 1.430 & .825 \\
Psuedo R square & .070 & .072 & & & \\
Number of cases & 455 & 437 & & & \\
\hline
\end{tabular}

Note: Reference category dependent variable $=$ warm

$* * *$ Effect significant at $p<.001$

$* *$ Effect significant at $p<.05$

*Effect significant at $p<.10$

Source: Own calculation based on TIES 


\subsection{Conclusion}

The four indicators of interethnic relations measure slightly different aspects of the phenomenon. The first indicator measures the overall evaluation of interethnic relations; the second, how interethnic relations have changed over the last five years; the third, whether living with other ethnic groups is perceived as threatening to one's own culture; and the fourth, how warmly respondents feel toward members of the other ethnic group. Interethnic contact (friendship and neighbourhood composition), having experienced discrimination and the timing of the interview (before or after the Bronze Soldier crisis) do influence responses among Estonians and Russians across these four models. The fact that the four indicators of interethnic relations measure different aspects of interethnic relations gives us a more nuanced look at how these variables influence relations between Estonians and Russians.

Having friends who are members of the out-group does increase the odds of viewing interethnic relations favourably among both Russian and Estonian respondents. Friendship was significant for Russian respondents in models one, three and four. However, it was only significant for Estonians in the fourth model. There are two possible explanations for this. First, several studies have noted that Estonians are increasingly irritated by the different cultural practices of ethnic Russians, and that Estonians in general feel that their culture has been threatened by the Russification policies of the Soviet period (Grenoble 2003; Petersoo 2007). Integration Monitoring in 2005 found that Estonians are increasingly disturbed by the different cultural practices of Russians. 80 per cent of Estonians are disturbed by the fact that Russians do not know Estonian; 78 per cent consider their way of life and thinking to be different from those of Russians; and 59 per cent of Estonians are disturbed by the different behaviour and lifestyle of Russians (Vetik et al. 2006). Consequently, whether or not having Russian friends influences perceptions of cultural threat would depend on the nature of those friendships. If Estonians are speaking Russian with their Russian friends, then there is little reason to believe that these friendships would reduce fears about cultural threat. A second possible explanation is that while respondents may have indicated having Russian friends, these contacts may not be 'close' contacts, but may consist of colleagues or be more akin to 'acquaintances'.

Living in ethnically unmixed neighbourhoods also appears to have opposite affects for ethnic Russians and ethnic Estonians. For Russians, living in ethnically unmixed neighbourhoods increases the odds of viewing interethnic relations negatively in models one and two. This supports the contact thesis that even generalised contact has some effect on establishing more positive attitudes toward interethnic relations. 
However, in the Estonian case, living in ethnically unmixed neighbourhoods decreases the odds of viewing interethnic relations negatively in models three and four. Ellison and Powers (I994) argue that casual everyday contact may have different effects for each group when relations are hierarchically structured. Among black Americans, for example, unintentional casual contact may increase anxiety because of the hierarchical nature of interethnic relations. Although the situation has been reversed since independence, most Estonians have the perception that Russians enjoyed a privileged position in Estonian society during the Soviet period. The prevalence of the Russian language in their own neighbourhood may therefore be viewed as threatening by ethnic Estonians. This may especially be true in Kohtla-Järve, where it would be much more difficult for Estonians to avoid generalised interethnic contact with Russians, owing to the demographic situation.

Having no experiences with discrimination on the basis of ethnicity did decrease the likelihood of viewing interethnic relations negatively for Russians in model one and for Estonians in model four. The most likely explanation for why discrimination was not more significant is that over 70 per cent of both Russian and Estonian respondents reported never having experienced discrimination. Consequently, the skewed nature of the sample with regard to this variable most likely underestimates its effect.

Some support is found for the impact of the Bronze Soldier crisis on views of interethnic relations. In models one, two and three, being interviewed before the crisis decreased the odds of Russians viewing interethnic relations negatively. This supports arguments regarding the negative impact of the crisis on interethnic relations. However, in model four, being interviewed before the crisis increases the odds that Russians would feel coolly toward Estonians. One possible explanation for this is that respondents did not feel comfortable indicating negative feelings toward Estonians after the Bronze Soldier crisis given its highly politicised nature. Another possible explanation is that the discussions surrounding the removal of the statue before the crisis had a great deal of influence on attitudes toward interethnic relations among Russians. For ethnic Estonians, being interviewed before the crisis decreases the odds of viewing interethnic relations negatively only in model three. It may be that the Bronze Soldier crisis has had a greater impact on the attitudes of Russian youth than Estonian youth.

Finally, demographic factors such as city and age group were significant in some models. However, they do not explain away the significance of other variables. Age group is only significant for Estonians in model one, with the younger age group being more likely to view interethnic relations as 'unfriendly'. Living in Tallinn increases the odds of viewing interethnic relations as unfriendly for Russians in model one 
and for seeing a worsening of relations between ethnic groups for both Russians and Estonians in model two. This most likely has to do with controversies leading up to the Bronze Soldier crisis, as well as the differences in the demographic situation of the two cities.

The results of the analysis point to interesting avenues for future research. They suggest that contact through friendship may have a larger influence on the attitudes of Russians than Estonians. In addition, living in ethnically unmixed neighbourhoods has contradictory effects for each group. Qualitative interviews with respondents would provide information about the nature of friendships more generally within each city, in order to draw out a more conclusive interpretation of the contact thesis in this case. Finally, re-interviewing respondents now, three years after the Bronze Soldier crisis, may lead to different findings about the impact of the crisis on interethnic attitudes.

\section{Notes}

I 'Russia indignant by destruction of Bronze Soldier in Tallinn', Tass 27 April 2007; 'Scores hurt, more than 600 detained as more riots rock Estonia', Agence France Presse 28 April 2007.

2 New Baltic Barometer, Center for the Study of Public Policy, University of Aberdeen, available at www.abdn.ac.uk/cspp/catalog2_o.shtml.

\section{References}

Aalto, P. (2003), 'Revisiting the security/identity puzzle in Russo-Estonian relations', Journal of Peace Research 40 (5): 573-591.

Aasland, A. \& T. Flotten (200I), 'Ethnicity and social exclusion in Estonia and Latvia', Europe-Asia Studies 53 (7): I033-I049.

Allport, G. (I954), The nature of prejudice. Reading: Addison Wesley.

Amir, Y. (I976), 'The role of intergroup contact in change of prejudice and race relations' in P.A. Katz (ed.), Towards the elimination of racism, 245-280. New York: Pergamon.

Aronson E. \& S. Patnoe. (I997), The jigsaw classroom. New York: Longman.

Barrington, L.W. (I997), 'Nation and nationalism: The misuse of key concepts in political science', PS: Political Science and Politics 30 (4): 712-716.

Belobrovtsev, V. (2008), 'Kuidas me kaotasime integratsiooni', Vikerkaar 23 (4-5): I2I-I28.

Brosig, M. (ed.) (2006), Human rights in Europe: A fragmented regime? Frankfurt: Peter Lang.

Brubaker, R. (I996), Nationalism reframed: Nationhood and the national question in the new Europe. Cambridge: Cambridge University Press.

Brubaker, R. (2004), Ethnicity without groups. Cambridge: Harvard University Press.

Bugajski, J. (2004), Cold peace: Russia's new imperialism. Westport: Praeger.

Chin, J. \& R. Kaiser (I996), Russians as the new minority: Ethnicity and nationalism in the Soviet successor states. Boulder: Westview Press.

Commercio, M. (2004), Exit and voice in the near abroad: The Russian minority in Kyrgystan, Kazakhstan, and Latvia. PhD dissertation, University of Pennsylvania. 
Connor, W. (1994), 'A nation is a nation, is a state, is an ethnic group, is a...' in W. Connor (ed.), Ethnonationalism: The quest for understanding, 90-II7. Princeton: Princeton University Press.

Cooley, A. (2003), 'Western conditions and domestic choices: The influence of external actors on the post-communist transition', in A. Karatnycky, A. Motyl \& A. Schnetzer (eds.), Nations in transit, 25-38. New York: Freedom House.

Csergo, Z. (2007), Talk of the nation: Language and conflict in Romania and Slovakia. Ithaca: Cornell University Press.

Ehala, M. (2009), 'The Bronze Soldier: Identity threat and maintenance in Estonian society', Journal of Baltic Studies 40 (I): I39-158.

Ellison, C. \& D. Powers (1994), 'The Contact Hypothesis and Racial Attitudes among Black Americans', Social Science Quarterly 75 (2): 385-400.

Galbreath, D.J. (2005), Nation-building and minority politics in post-socialist states: Interests, influences and identities in Estonia and Latvia. Stuttgart: Ibidem-Verlag.

Galezis, N. (2000), The effects of EU conditionality on citizenship policies and protection of national minorities in the Baltic states, EUI. Working Paper RSC No. 2000/68, Badia Fiesolana, San Domenico (FI).

Gardiner, S. (1972), 'Complexity training and prejudice reduction', Journal of Applied Social Psychology 2: 326-342.

Hallik, K. \& V. Pettai. (2002), 'Understanding processes of ethnic control: Segmentation, dependency, and co-optation in post-communist Estonia', Nations and Nationalism 8 (4): 505-529.

Hallik, K., J. Kruusvall, I. Pettai, M. Pavelson, I. Proos \& R. Vetik (2002), Integration of Estonian society: Monitoring 2002, Tallinn: Institute of International and Social Studies.

Hastings, A. (1997), The construction of nationhood: Ethnicity, religion and nationalism. Cambridge: Cambridge University Press.

Hays, B. \& L. Dowds (2006), 'Social contact, cultural marginality or economic self-interest? Attitudes towards immigrants in Northern Ireland', Journal of Ethnic and Migration Studies 32 (3): 455-476.

Hewstone, M. \& R. Brown (eds.) (1986), Contact and conflict in intergroup encounters. Oxford: Blackwell.

Jackman, M.R. \& M. Crane (I986), “Some of my best friends are black": Interracial friendship and whites' racial attitudes', Public Opinion Quarterly 50: 459-486.

Kelley, J. (2004), Ethnic politics in Europe. Princeton: Princeton University Press.

King, C. \& N.J. Melvin (1999/2000), 'Diaspora politics: Ethnic linkages, foreign policy and security in Eurasia', International Security 24 (3): 108-г 8.

Kolstoe, P. (I995), Russians in the former Soviet republics. Bloomington: Indiana University Press.

Kolstoe, P. (ed.) (2002), National integration and violent conflict in post-Soviet societies: The cases of Estonia and Moldova. Lanham: Rowman \& Littlefield.

Korts, K. (2009), 'Interethnic attitudes and contacts between ethnic groups in Estonia', Journal of Baltic Studies 40 (I): I2I-I37.

Laitin, D. (1998), Identity in formation: The Russian-speaking populations in the near abroad. Ithaca: Cornell University Press.

Lauristin, M. \& R. Vetik (2000), Integration of Estonian society: Monitoring 2000. Tallinn: Integration Foundation.

Lauristin, M. \& T. Vihalemm (1997), 'Changing value systems: Civilisational shift and local differences', in M. Lauristin \& P. Vihalemm (eds.), Return to the Western world: Cultural and political perspectives on the Estonian post-communist transition, 243-263. Tartu: Tartu University Press.

Lobjakas, A. (2008), 'Huntington ja kartulikoored', Vikerkaar 23 (4-5): I28-I34. 
Lustick, I. (I979), 'Stability in deeply divided societies: Consociationalism versus control', World Politics 3I (3): 325-44.

Lustick, I. (I980), Arabs in the Jewish state: Israel's control of a national minority. Austin: University of Texas Press.

Made, V. (2003), 'Estonia and Europe: A common identity or an identity crisis?', in M. Lehti \& D.J. Smith (eds.), Post-cold war identity politics: Northern and Baltic experiences, I83-I98. London: Frank Cass.

Melvin, N. (1995), Russians beyond Russia: The politics of national identity. London: The Royal Institute for International Affairs.

Petersoo, P. (2007), 'Reconsidering otherness: Constructing Estonian identity', Nations and Nationalism I3 (I): II7-I33.

Pettigrew, T.F. (I997a), 'Generalized intergroup contact effects on prejudice’, Perspectives on Social Psychology Bulletin 23: I73-185.

Pettigrew, T.F. (I997b), 'The affective component of prejudice: Empirical support for the new view', in S.A. Tuch \& J.K. Martin (eds.), Racial attitudes in the 199os: Continuity and change, 76-90. Westport: Praeger.

Pettigrew, T.F. (1998), 'Intergroup contact theory', Annual Review of Psychology 49: 65-68.

Pettigrew, T.F. \& R.W. Meertens (I995), 'Subtle and blatant prejudice in Western Europe', European Journal of Social Psychology 25: 57-75.

Pettigrew, T.F. \& L.R. Tropp (2006), 'A meta-analytic test of intergroup contact theory', Journal of Personality and Social Psychology 90: 75I-783.

Schulze, J.L. (20I0), 'Estonia caught between East and West: EU conditionality, Russia's activism and minority inclusion', Nationalities Papers.

Sigelman, L. \& S. Welch (I993), 'The contact hypothesis revisited: Interracial contact and positive racial attitudes', Social Forces 7I: 78I-95.

Simonsen, S.G. (200I), 'Compatriot games: Explaining the "diaspora linkage” in Russia's military withdrawal from the Baltic states', Europe-Asia Studies 53 (5): 77I-792.

Smith, C.B. (1994), 'Back and to the future: The intergroup contact hypothesis revisited', Social Inquiry 64: 438-55.

Smith, G. (1996), 'The ethnic democracy thesis and the citizenship question in Estonia and Latvia', Nationalities Papers 24 (2): 199-216.

Smith, G. (1999), 'Transnational politics and the Russian diaspora', Ethnic and Racial Studies $22(3):$ 500-523.

Smith, K.E. (200I), 'Western actors and the promotion of democracy', in J. Zielonka \& A. Pravda (eds.), Democratic consolidation in Eastern Europe, Volume 2: International and transnational factors, 3I-57. Oxford: Oxford University Press.

Stephan C.W. \& W.G. Stephan (I984), 'The role of ignorance in intergroup relations', in N. Miller \& M.B. Brewer (eds.), Groups in contact: The psychology of desegregation, 229255. Orlando: Academic.

Weldon, D.E., D.E. Carlson, A.K. Rissman, L. Slobbodin \& H.C. Triandis (I975), 'A laboratory test of effects of culture assimilator training', Journal of Personality and Social Psychology 32: 300-310.

Williams, R.M. Jr. (I947), The reduction of intergroup tensions. New York: Social Science Research Council.

Wilner, D., M, Rosabelle, P. Walkley \& S.W. Cook (1955), Human relations in interracial housing: A study of the contact hypothesis. Minneapolis: University of Minnesota Press.

Vachudova, M.A. (2005), Europe Undivided: Democracy, leverage \& integration after communism. Oxford: Oxford University Press.

Vetik, R. (2008), 'Etniline domineerimine Eestis', in P. Petersoo \& Tamm, M. (eds.), Monumentaalne konflikt: mälu, poliitika ja identiteet ta"napa"eva Eestis, II2-26. Tallinn: Varrak. 
Vetik, R., K. Hallik, J. Kruusvall, M. Pavelson, I. Pettai \& I. Proos (2006), Integration of Estonian society: Monitoring 2005, Tallinn: Institute of International and Social Studies. 


\title{
9 Gender role attitudes
}

\author{
Leeni Hansson
}

\subsection{Introduction}

The studies on gender-related social processes have pointed to an inequality in the distribution of resources and opportunities between men and women, both in the Western and in Eastern European countries (Hanson \& Wells-Dang 2006). On the one hand, opportunities and choices for men and women depend on the gender ideology and labour market policies of the country. On the other hand, they also depend on prevailing currents in the gender role attitudes of the society and in the individual's attitudes (Barber \& Axinn I998). The studies carried out in Estonia in the last decade, for instance the Gender Equality Monitoring carried out in 2005 (Soolise võrdõiguslikkuse ... 2005), have shown that two ethnic and linguistic groups - Russian speakers with an immigrant background and native Estonians - held somewhat different attitudes towards gender roles. In many aspects, the gender role attitudes of Russians seem to be more traditional than the attitudes of native Estonians. However, to date there has been no systematic analysis of whether second-generation immigrants share the attitudes of their parents' generation, or to what extent support for more traditional gender roles come from structural or cultural factors.

A number of studies, which have analysed the changes in gender role attitudes in Western countries, have revealed that along with a rapid increase of female employment, the gender systems have also changed and the traditional male breadwinner family model of the I950s has been replaced by a model of gender equality (Hirdman I99I). Accordingly, in these countries the gender role attitudes are also changing, the changes being most noticeable in the Nordic countries (Grönroos \& Lorenzen 2003; Lück 2005). Compared to Western countries, the former socialist countries have followed a different path in terms of gender issues. In the Soviet period, these countries were characterised by a discrepancy between the official gender ideology and the everyday gendered practices. In practical terms, it meant that full female employment coexisted with traditional gender roles and unequal division of household tasks in the domestic sphere. Furthermore, while in Western countries the I990s were characterised by an increasing 
support of egalitarian gender roles, in the post-socialist countries, the political and economic reforms of the I990s evoke a shift towards more traditional attitudes (Narusk \& Kandolin I997; Rotkirch \& Temkina I997; Motiejunaite 2005).

Attitudes are cultural and part of the general system of values. According to Alice Eagly and Shelly Chaiken (I993), attitudes are expressed by evaluating a particular role or behaviour with some degree of favour or disfavour. Values and attitudes are shaped by socialisation within a certain cultural context. Empirical research suggests that parents socialise their children according to their cultural beliefs, values, attitudes and behaviours (Romero, Cuellar \& Roberts 2000). Thus, it can be hypothesised that individuals who have been socialised in different cultural environments could differ in their attitudes towards the roles and responsibilities of men and women.

Research literature suggests that compared to the dominant population, immigrant population groups are often characterised by more traditional gender role attitudes. In turn, traditional attitudes influence a wide range of behaviours, including work, education and family life. Harald Bauder (2006: 7I0) calls attitudes 'contributing factors of ethnic differences in the labour market'. Recent studies have revealed that compared to native Estonians, the Russian population with an immigrant background has a rather disadvantaged position in the labour market. The share of Russian speakers in high-income population groups is also relatively small (see Vöörmann \& Helemäe in this volume). Unfortunately, few empirical studies have touched the effects of attitudes in the immigrants' disadvantaged labour market situation. Using the data of the Russian Second Generation Survey, this study aims to examine the gender role attitudes among second-generation Russians in Estonia. Two types of attitude scales are used: attitudes towards women's roles in the public sphere and attitudes towards gender roles in the domestic sphere. Native Estonians are used as a reference group. The sample consists of young people aged I8-35 - the age at which the choices among role alternatives may influence not only the present situation but also subsequent decisions in the coming years.

\subsection{Theoretical approaches}

\subsubsection{Attitudes towards gender roles}

Gender role attitudes are opinions and beliefs about which roles men or women should fulfil in families, work life and in the society overall. In the first half of the twentieth century, Europeans shared a traditional understanding that men and women should fulfil distinct roles - the breadwinner's role being a natural role for a man, whereas the 
caregiver's role was considered the best option for a woman (Riley 2003). Researchers usually differentiate between 'traditional' attitudes, which refer to the attitudes held by the majority of people in Western countries in the I950s and 'modern' or 'egalitarian' ones that oppose the traditional attitudes and stress gender equality (Barber \& Axinn I998).

There is evidence that in the countries characterised by a turn towards egalitarian gender role attitudes, e.g. the Nordic countries, the changes towards more egalitarian attitudes have proceeded more quickly for women than for men (Baxter \& Kane I995; Bryant 2003). Several studies have shown that besides gender, egalitarian gender role attitudes relate to youth and a higher level of education, while older age and a lower educational level predict more support for traditional gender roles (ibid.). Religiosity is also considered to be a predictor of traditional gender role attitudes (Diehl, Koenig \& Ruckdeschel 2009).

Joop van der Plight and Nanne De Vries (I998) have come up with categories to distinguish between different functions of attitudes, such as an instrumental function, an ego-defensive function, a social assimilative function, etc. One of the main topics in the discussions on attitudes has been the relationship between gender role attitudes and gendered behaviours. For instance, a woman may support quite traditional attitudes and feel that, in general, mothers of pre-school age children should not work, but she herself may choose a career woman's path. On the other hand, women who believe that mothers of small children should stay at home, but who would like to have a career, are very likely to postpone marriage and the transition to parenthood due to conflicting role expectations. Although the research on attitudes-behaviours links has given contradictory results, it is generally assumed that attitudes - although not always directly linked to behaviour - still play a significant role in marriage and reproductive patterns (Barber \& Axinn I998), as well as in maintaining gender inequalities in the labour market (Vella I994).

Gender behaviour in the domestic sphere, such as the division of household tasks between the spouses or cohabiting partners and decision-making in the family, are related by many researchers to resources available to the spouses or partners (Treas I993). Traditionally, women had fewer resources and, accordingly, it was considered fair that the wife took a greater share of the housework than the husband did. However, empirical research has shown that an increase in women's resources, such as better education or full-time employment, does not necessarily lead to a more egalitarian division of tasks and responsibilities in the family. Thus, gender behaviour seems to be influenced not only by individual factors but also by cultural norms (Diehl 2009). 
The majority of studies that deal with ethnic differences in gender role attitudes focus on comparisons between countries (Baxter \& Kane I995; Treas \& Widmer 2000; Inglehart \& Norris 2003; Safiro, Himelein \& Best 2003; Apparala, Reifman \& Munsch 2003; Evertsson \& Nermo 2004; Motiejunaite \& Kravchenko 2008; Knudsen \& Wærness 2008). Country-specific differences in gender role attitudes are mostly explained by macro-level factors, such as dominant gender ideologies, gender-related policies, state religion and religiosity of the population, historical background, etc. In the cross-country comparison, the researchers usually assume that the members of a society share common attitudes and values. However, the secondary analysis of the I990-I993 World Value Survey data reveals that in those countries in which it was possible to discern ethnic characteristics for different population groups, ethnic differences within a country were statistically significant and frequently more significant than the differences between countries (Silver \& Dowley 2000). The findings of the analysis by Silver and Dowley (ibid.) show that Estonia was among the countries where ethnic differences in the values, i.e. differences in the values of Estonians and Russians, were significant.

Empirical research on variation in gender role attitudes between ethnic groups and within a country is so far limited to a few studies (see e. g. Pinto \& Coltrane 2009; Diehl et al. 2009). These surveys were undertaken in Western countries where the share of immigrant population was relatively large. The results of the studies suggest that more traditional gender role attitudes of immigrant women often result in low work orientation and, accordingly, they deprive themselves of many career choices, including access to high-salaried occupations usually dominated by males (Bauder 2006). There is also evidence that employers find it easier to underpay female employees whose work orientation is low (Ashwin 2002).

\subsubsection{The Soviet gender system}

It is necessary to understand that young people of both ethnic groups in Estonia were socialised by parents whose normative framework, in which they had taken decisions regarding employment and family roles, differed from the situation of today. Thus, one could expect that the socialisation of young people in both ethnic groups might have had some elements of Soviet gender ideology. In order to understand current gender issues better, let us start with an overview of the Soviet gender system.

In the Soviet Union, the male breadwinner family model, characteristic of the majority of Western countries until the end of the I950s, was seriously challenged. Gender equity was presented as official ideology 
and female education and labour force participation was facilitated by widely available childcare services. As a result, compared to Western countries, female employment rates were remarkably high. Some researchers (e.g. Rotkirch \& Temkina I997) have characterised the Soviet gender system as the system of the 'working mother', with the emphasis on the latter word. In spite of official gender ideology and a high female employment rate, the Soviet gender system was characterised not only by strict separation of female and male spheres and vertical and horizontal segregation on the labour market, but also by the biological essentialist approach to women (Liljeström I992; Narusk I992). Accordingly, the state policies protected motherhood, rather than parenthood in general (Zdravomyslova 2004). The official gender ideology encouraged gender equality in the public sphere but left the traditional gender roles in the domestic sphere untouched. Studies have revealed that although women's relative workload at home was significantly higher than that of men's, women mostly accepted the double burden and considered it natural (Narusk I992). Thus, the private/domestic sphere traditionally assigned to women remained the women's domain also under Soviet rule (Temkina \& Zdravomyslova 2003).

Researchers focusing on Soviet gender ideology (e.g. ibid.; Temkina $\&$ Rotkirch 2002) have characterised the Soviet gender system as a system comprised of different gender contracts. Temkina and Zdravomyslova (2003) define a gender contract as a compromise made about the gender division of labour, at work and in the family. According to the official contract, Soviet women were supposed to participate in the labour force and combine full time employment with motherhood and a family. As mentioned, the combination of work and family related roles was facilitated by childcare support, including maternity leave and benefits (see Narusk I992 for a detailed description of Soviet family politics).

Temkina and Rotkirch (2002) have shown that besides the 'official' gender contract, there also existed the so-called 'everyday' contracts, which were sustained through the individuals' behaviour, relationships and attitudes. As the definition of an 'everyday' contract involves both behaviours and attitudes, Motiejunaite and Kravchenko (2008) added the term 'normative contract' to describe mainly the attitudes towards the roles of men and women. Thus, while speaking of Soviet gender contracts, we can differentiate between the 'official', 'normative' and 'everyday' gender contracts. Zdravomyslova (2004) has described the late-Soviet gender order as hypocritical, characterised by a discrepancy between the official gender contract supported by the state ideology and the 'shadow' contracts that characterised everyday life. 


\subsubsection{Post-Soviet gender contracts}

In Estonia, as in other post-Soviet countries, the political and economic reforms of the I990s brought about fundamental changes in the labour market and in the status hierarchy of economic sectors and occupations. The changes were less favourable for Russians, who mostly worked in the economic sector during the Soviet period. These sectors lost their importance in the course of market reforms. One of the major changes for women was the abolishment of the work obligation. If under the official Soviet gender contract women were obliged to work, then in the I990s Estonian women obtained the right not to work. As a result, in the early I990s the researchers noticed a surprising trend in Estonia. Instead of desires for greater gender equality, the early i990s were characterised by the trends of re-traditionalisation - the revival of traditional gender role attitudes and ideas of 'natural' roles of men and women (Narusk \& Kandolin I997). The backward trend in terms of gender equality was explained, first, as a reaction to the former hypocritical gender ideology of the Soviet regime. For many women, the right not to work and the right to become a stay-at-home mother seemed to be an important aspect of 'normality' (Motiejunaite 2005). The housewife's role and emphasis on femininity were perceived by many young women as elements of the Western value system and lifestyle. Trends of re-traditionalisation were supported by the public discourse of idealised motherhood and attempts to recreate the national identity based on the traditional pre-war family model of the i930s (Narusk I997).

However, the period of a 'renaissance' of traditional values turned out to be short-lived, as the majority of Estonian women had only a theoretical choice between different roles (Narusk \& Kandolin I997). First, the economic situation of families made the choice between paid employment and full time housewifery impossible, as in the majority of families the incomes of both spouses or partners were badly needed. Second, the well-educated women in Estonia were mostly committed to their jobs and wanted to continue in active employment not only for financial reasons but also for self-realisation. Third, closer contacts with the Western world, and especially with the Nordic countries, introduced a more liberal approach to gender roles and more egalitarian models of gender relations both in the public as well as in the private sphere. Accordingly, the share of women who actually chose the role of a stayat-home mother and housewife was relatively small and the fears of the return of the male breadwinner family model had no solid ground in Estonia.

In the late I990s, new trends were noticeable in gender role attitudes. In the post-Soviet period, the former official gender contract of the working mother continued to dominate in practice, but instead of 
the emphasis being on the 'working mother', the emphasis was shifted to the 'working mother' (Temkina \& Zdravomyslova 2003). Furthermore, Temkina and Zdravomyslova (ibid.) suggest that in the post-Soviet period the gender contract related to female employment was split into different subcontracts, including the subcontracts of the work-oriented career woman, and that of a part-timer or a stay-at-home mother.

In 2004, the Gender Equality Law Act was adopted by the Estonian Parliament. In Estonia, gender equality is legally guaranteed not only by the Gender Equality Law Act but also by other labour and family policy. However, in spite of the new acts that aimed to facilitate gender equality, the Estonian labour market is still characterised by significant vertical and horizontal gender segregation. Compared to other countries of the European Union, Estonia is also characterised by a relatively high gender pay gap. For example, in 2006, the pay gap between men and women (25 per cent) was the highest among European Union member states (Equality between ... 2008). The pay differences are usually explained by factors like education, ethnicity, language skills, working time, contract type, region, occupation and sector. However, empirical research has revealed that traditional gender roles and stereotypes, i.e. images of 'proper' male and female roles can also be an obstacle for labour market outcomes and a path to lower-paid 'female' jobs for women.

Unlike the Soviet gender ideology, Estonian family policies and the policy measures of today are aimed at facilitating the reconciliation of work and family related roles and support working parents and not just working mothers, as was the case in the Soviet period. In recent years, the ideas of involved fatherhood have been growing in Estonia and young fathers are more involved in parenting and household chores than their fathers' generation (Pajumets 2007). It should be stressed that Estonian family policies are universal, i.e. not related to ethnicity, immigration histories or citizenship status.

Recent studies carried out in Estonia, e.g. the Gender Equality Monitoring carried out in 2005 , have revealed that the responses of the representatives of different ethnic groups to the gender equality issues have varied. For example, Russians are more supportive towards traditional gender roles than native Estonians (Soolise võrdõiguslikkuse... 2005). The above-mentioned study covered the population aged I5-74, and there was no data that would allow us to differentiate between the attitudes of first- or second-generation immigrants. Russian second-generation immigrants and native Estonian youth were brought up in the same society by parents whose gender role attitudes had been developed under the Soviet rule and according to the Soviet gender ideology. As we know, primary socialisation takes place in the family, followed by 
socialisation that takes place in the school system. Young Estonians were socialised in a cultural environment that, according to several cultural dimensions (see Hofstede I980), was closer to Nordic countries, which were characterised by less traditional gender ideology than that of the former Soviet Union or today's Russia. Accordingly, it can be hypothesised that the gender role attitudes of second-generation Russians could be based on somewhat different cultural values than the attitudes of native Estonians. On the other hand, the second-generation immigrants born in Estonia have much in common with young Estonians. Their language skills are better than the skills of their parents' generation, they can follow the Estonian media, many of them have Estonian workmates, neighbours or friends. Accordingly, one could expect that the differences in gender role attitudes between second-generation Russians and native Estonians could be smaller than the findings of general population surveys have shown.

Based on the above-mentioned theoretical assumptions and findings of previous studies, the intention of the present study is to find out to what extent gender role attitudes of second-generation Russians differ from the attitudes of native Estonians, and what are the main factors that influence the development of attitudes. As previously mentioned, the gender ideology of the Soviet past, which was mostly focused on gender equality in the public sphere - leaving the domestic/private sphere mainly as the women's domain - has influenced the socialisation processes in both Estonian and Russian families. Among secondgeneration immigrants, ethnic ties and identities might have been maintained, primarily, in the family circle. Accordingly, our first task was to find out whether the ethnic differences in the attitudes towards gender roles in the public sphere were less significant than differences in the attitudes towards family-related gender roles. Secondly, the results of previous studies suggest that in the countries characterised by a turn to less traditional gender roles, the changes have proceeded more quickly for women and for younger and better educated population groups (Baxter \& Kane I995; Bryant 2003). For this reason, we are interested in the role of gender, age and education in the formation of more egalitarian attitudes towards gender roles. Third, empirical research has indicated (see e.g. Pinto \& Coltrane 2009) that, generally, the more traditional gender role attitudes of the representatives of immigrants and minority groups are more often influenced by cultural norms and values, whereas those of the dominant group are more often influenced by structural factors. Accordingly, using the Russian Second Generation Survey data we tried to find out whether cultural and structural factors had different effects on the gender role attitudes of young Russians, when compared to young Estonians. 


\subsection{Variables and methods}

The Russian Second Generation Survey instrument contained some suitable indicators that measured attitudes regarding women's roles in the public sphere. In addition, several items measured both the actual division of household tasks and attitudes regarding the division of tasks and responsibilities in the family. Accordingly, two measures were developed to investigate the differences in gender role attitudes of young Russians and Estonians. The first measure was constructed for assessing attitudes towards women's roles in the public sphere, and the second one for assessing attitudes towards gender roles in the private/domestic sphere.

The measure for assessing attitudes towards women's roles in the public sphere was constructed using the responses to the following three statements: I) 'Women should not go to work when there are small children in the family'; 2) 'It goes against nature when women in leading positions are given authority over men'; 3) 'Study and higher education are less important for women than for men'. A Likert-style five-point scale, ranging from I (strongly agree) to 5 (strongly disagree), was employed. In constructing the measure, the values of the responses were summed and reversed, so that higher scores represented preferences of more traditional gender roles, and lower scores preferences of least traditional roles. The scale ranged from 3, indicating the least traditional attitudes, to 15 , indicating the most traditional attitudes.

On the behavioural level, five items, characterising the division of household tasks between the spouses or cohabiting partners, measured gender equality in the private sphere, i.e. division of housework. Respondents were presented with the following question: 'In your household, who generally takes care of the following tasks ...?' There were five tasks listed: I) taking care of children; 2) doing the routine household chores; 3) preparing the daily meal; 4) taking care of financial/administrative matters; 5) earning money. The response options were: mostly the respondent; mostly the partner; mostly the spouses or partners equally, mostly a third person. The division of household tasks was labelled 'traditional' if the female partner was responsible for the household tasks usually referred to as typical women's tasks (items I-3), and the male partner was responsible for typical men's tasks (items 45). The equal division of tasks, i.e. tasks shared by the spouses or partners, was labelled as 'non-traditional'. Immediately following the question about the division of tasks, respondents were asked how satisfied they were with the division of housework in the family. The responses were coded from I (fully satisfied) to 5 (fully dissatisfied).

The attitudes towards gender roles in the domestic/private sphere were measured through the responses to the statements similar to the 
statements used for measuring actual division of tasks in the family. The respondents were asked how the household tasks should be divided in an imaginary family consisting of a mother, father and children. The attitudes were labelled as traditional or non-traditional, using the same logics as in case of actual division of tasks, i.e. in the items I- 3 the responses 'mother should' and in the items 4-5 'father should' represented traditional attitudes (coded I), and 'both spouses equally' represented non-traditional attitudes (coded I). The scores were summed when constructing the scale for the attitudes towards gender roles in the private/domestic sphere.

Based on the literature and findings of previous empirical research, three sets of independent variables were selected for use in the analyses. In the first set, there were individual characteristics like ethnicity (Russian, Estonian), gender (male, female) and age (18-25, 26-35). In the second set of independent variables, there was the respondent's educational level (basic, general secondary, vocational secondary, tertiary level) and career advancement (better than expected, as expected, worse than expected). In the third set, their economic situation (can manage well, can manage, has problems) and place of residence (capital city, north-eastern Estonian industrial city) were used.

Variations in gender role attitudes in both spheres were assessed using descriptive statistics and General Linear Models (GLM) analyses. To determine the influence of independent variables on the gender role attitudes of Russians and Estonians, GLM analysis was also conducted separately for both ethnic groups. Missing data were excluded listwise for each analysis, resulting in differences in the degrees of freedom.

\subsection{Results}

A closer look at the family behaviour of young people of two ethnic groups in Estonia revealed that the patterns of partnership formation of second-generation Russians were quite similar to those of young Estonians. In both groups, partners were mostly found through ties based on studies and through work-related or friendship-based networks. However, the fact that 58 per cent of Russians aged I8-35 were officially married to their partner suggests that second-generation Russians seemed to follow relatively more traditional marriage patterns than Estonians. Among Estonians, aged I8-35, the share of respondents who were married to their partner was about 30 per cent, the rest being in non-marital cohabiting unions. Vöörmann and Helemäe (in the present volume) have revealed that compared to Estonian women, the percentage of housewives and mothers on parental leave is somewhat greater among Russian women. 
According to official statistics, Russian-Estonian mixed marriages are not common in Estonia. The last census, carried out in 2000, puts the share of Estonian-Russian couples at only 4 per cent of all married couples, the share being quite similar among cohabiting couples.

\subsubsection{Attitudes towards women's role in the public sphere}

Young people's attitudes towards women's roles in the public sphere were assessed by asking the respondents whether they agreed or disagreed with the statements listed in Table 9.I. Table 9.I displays the share of respondents who reported answers of 'strongly agreed' or 'agreed' with the statements. The results show the attitudes of young people seem to be quite traditional concerning the statement about employment of mothers of small children. The majority of respondents in both ethnic groups were of the opinion that mothers should not work. For ease of interpretation, it should be noted that in the survey, the age of the child was not specified. According to the Estonian Parental Benefit Act, it is possible for a mother or a father to stay at home until the child is I.5 years old, and for that period the stay-at-home parent is paid Ioo per cent of her/his average salary of the previous year. Although the policy measure is parent-centred, until now parental leave has mostly been used by mothers. The share of fathers who have used parental leave is about 5 per cent. It is possible to imagine, then, that it was the leave covered by this parental benefit that the majority of respondents had in mind when suggesting that mothers of small children should to stay at home, and not the revival of the traditional male breadwinner family model.

In the responses to the statements concerning women holding leading positions, young Russians seemed to be less traditional than young Estonians. The responses to the statements concerning the importance of higher education for men and women gave the opposite result: the

Table 9.1 Agreement with statements concerning women's roles in the public sphere (in \%)

\begin{tabular}{|c|c|c|c|c|}
\hline & \multicolumn{2}{|c|}{ Russians } & \multicolumn{2}{|c|}{ Estonians } \\
\hline & Male & Female & Male & Female \\
\hline $\begin{array}{l}\text { 'Women should not go to work when there are } \\
\text { small children in the family' }\end{array}$ & 82 & 76 & 81 & 76 \\
\hline $\begin{array}{l}\text { 'It's not natural when women in leading positions } \\
\text { are given authority over men' }\end{array}$ & 15 & 12 & 24 & 18 \\
\hline $\begin{array}{l}\text { 'Studying and higher education are less important } \\
\text { for women than for men' }\end{array}$ & 14 & 8 & 2 & 4 \\
\hline
\end{tabular}

Source: Own calculation based on TIES 
share of supporters of the statement that higher education was less important for women than for men was greater among young Russians.

In general, with the exception of the first statement concerning employment of mothers with small children, which was supported by the majority of both Russians and Estonians, the share of respondents who supported outdated statements 2 and 3 was relatively smaller in both ethnic groups. Thus, as was expected, the attitudes of second-generation Russians towards women's roles in the public sphere were mostly nontraditional and rather similar to those of native Estonians.

\subsubsection{Actual division of household tasks}

Previous studies have revealed that the principles of equity of opportunities in the public sphere are accepted more easily than the equity of responsibilities of men and women in the domestic sphere (Narusk \& Kandolin I997). Both in the Soviet period, as well as in the post-Soviet period, women who were employed full-time continued to fulfil their 'feminine' roles - tasks and responsibilities related to housekeeping and childcare.

In the present study, in the analysis of actual division of household tasks and responsibilities, it was possible to differentiate between two groups of respondents - everyday practices in the division of tasks in the families with children and in the households of childless couples. Table 9.2 presents descriptive statistics concerning the actual division of domestic tasks and attitudes.

Table 9.2 shows that compared to the families with children, in both ethnic groups household tasks were more equally shared by the spouses or cohabiting partners without children. In the families with children, where the amount of housework is usually bigger than in the childless households, the equal share of tasks seemed to diminish. In the

Table 9.2 Actual division of household tasks in two types of households (in \%)

\begin{tabular}{lccccc}
\hline Household tasks & \multicolumn{3}{c}{ Household tasks shared equally } \\
\cline { 2 - 3 } & \multicolumn{2}{c}{ with children } & & without children \\
\cline { 2 - 3 } \cline { 5 - 6 } & Russians & Estonians & & Russians & Estonians \\
\hline Looking after children & 24 & 29 & & NA & NA \\
Routine household chores & 26 & 24 & & 46 & 48 \\
Daily meals & 21 & 17 & & 39 & 26 \\
Financial and administrative matters & 40 & 40 & & 49 & 56 \\
Earning money & 36 & 40 & & 55 & 74 \\
Satisfied with the division of tasks & 72 & 74 & & 88 & 90 \\
\hline
\end{tabular}

Source: Own calculation based on TIES 
families where the tasks were not shared equally, women mostly took care of the traditional 'female' tasks and men were responsible for earning money. Ethnic differences were most noticeable concerning traditional 'male' tasks like earning money, particularly in childless households. Among Russians, an equal share of financial responsibilities was even less common than among Estonian couples.

Further analysis showed that although in the majority of families household tasks were not shared equally, both Russians and Estonians seemed to be satisfied with the situation as it was. However, the survey results showed that in the childless households where the division of household tasks and responsibilities was more equal, the share of respondents who were satisfied with the situation was somewhat greater than among respondents with children.

\subsubsection{Attitudes towards gender roles in the domestic sphere}

The respondents who were not living with a permanent partner, and could not answer the questions concerning the actual division of household tasks in the family, as well as the respondents with no children, were asked to report their attitudes about how household tasks should be shared by the spouses in imaginary families with a mother, a father and children. Although there were no significant ethnic differences in actual division of domestic tasks, especially in the families with children, Table 9.3 shows that ethnic differences in the attitudes towards gender roles in the domestic sphere were significant. The share of respondents supporting a traditional division of domestic tasks on the attitude level was greater among young Russians than among Estonians.

Ethnic differences were especially noticeable in attitudes concerning a father's role in the family. Among second-generation Russians, and among Russian men in particular, traditional attitudes towards the division of household tasks seemed to be more widespread than among young Estonians. Thus, the traditional male breadwinner family model

Table 9.3 Attitudes towards the division of household tasks in imaginary families with children, support of the traditional division of tasks (in \%)

\begin{tabular}{lcccccc}
\hline Household tasks & \multicolumn{2}{c}{ Russians } & & \multicolumn{2}{c}{ Estonians } \\
\cline { 2 - 3 } & Male & Female & & Male & Female \\
\hline Looking after children (mother's task) & 42 & 25 & & 27 & 17 \\
Routine household chores (mother's task) & 30 & 33 & & 22 & 23 \\
Daily meals (mother's task) & 50 & 56 & & 54 & 47 \\
Financial and administrative matters (father's task) & 57 & 40 & & 46 & 33 \\
Earning money (father's task) & 63 & 52 & & 48 & 34 \\
\hline
\end{tabular}

Source: Own calculation based on TIES 
seems to be an ideal family model for many second-generation Russians in Estonia.

\subsubsection{Attitude scales and individual characteristics}

Further analysis was based on two gender role attitude scales. As mentioned, the scale 'women's role in the public sphere' was constructed as a three-item scale and the scale 'gender roles in the domestic/private sphere' as a five-item scale. The results of the GLM analyses on both scales are presented in Table 9.4. Since we were interested in ethnic differences in gender role attitudes, ethnicity was entered as an independent variable in all three models.

The variation in the attitudes towards women's roles in the public sphere can be explained, first of all, by gender and education, which were statistically significant at the $\mathrm{p}<$.ooI level. The fact that women have less traditional attitudes than men is hardly surprising. The effect of education confirms the results of previous studies that found that better educated women - in our case those with university-level education - have more egalitarian attitudes towards gender roles, especially towards women's roles in the public sphere. The research literature usually suggests that youth is a significant determinant of less traditional gender role attitudes. However, as the table shows, in our case the effect of age was insignificant in both attitude scales. This can be explained by the characteristics of the survey sample. While speaking of

Table 9.4 Summary of GLM results on two attitude scales, F-value and significance

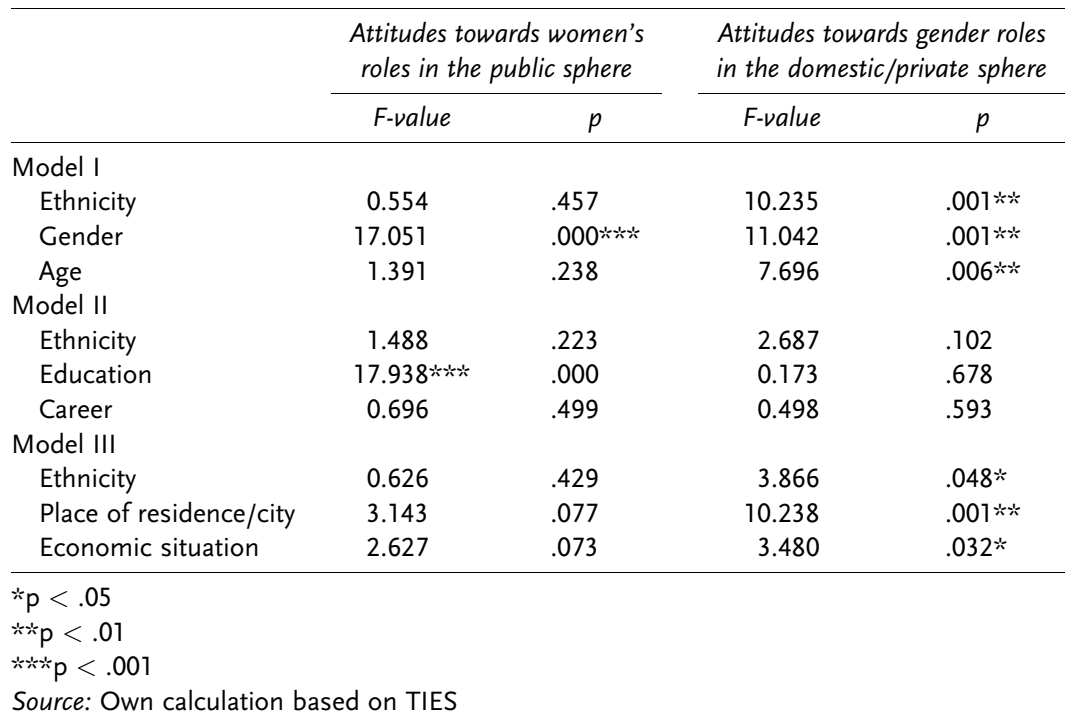


the effect of age, researchers usually compare younger age groups, i.e. those under 35, and older ones, i.e. the age group $35^{+}$. In our case, the survey sample consisted of respondents aged i8-35, which most studies define as the younger age group. Thus, we could say that there were no differences in the attitudes towards women's roles in the public sphere between two subgroups of young people. Furthermore, as the table shows, ethnic differences in the attitudes towards women's roles in the public sphere were insignificant.

The attitudes towards gender roles in the private/domestic sphere were less uniform. Traditional or non-traditional attitudes were determined by several factors. As the second column of Table 9.4 shows, there were statistically significant differences based on gender, ethnicity and age. The effect of ethnicity, which was not significant in the attitudes towards women's roles in the public sphere, turned out to be almost as significant as the effect of gender in relation to attitudes towards gender roles in the private sphere. The effect of age was also significant. However, the effect of age was somewhat surprising, as the attitudes of those aged I8-25 were more traditional than the attitudes of the age group 26-35. Among the structural characteristics, which were not significant in terms of attitudes towards the public sphere, the place of residence and the economic situation, turned out to be significant in relation to attitudes towards gender roles in the private sphere. Estonian men living in the capital city Tallinn were considerably more traditional in their attitudes towards gender roles in the private sphere than those living in Kohtla-Järve, a smaller city in eastern Estonia.

The result of the analysis showed that the main effect of education on the gender role attitudes in the private sphere was statistically insignificant. The result was unexpected, since education was significant in the women's role in the public sphere scale. This also contradicts the result of the previous studies.

In summary, the study revealed that ethnic differences in the attitudes towards gender roles in the public sphere were less significant than differences in the attitudes towards gender roles in the private/domestic sphere. The second research question concerning the role of gender and education showed that as expected, gender was significant in both attitude scales, with women holding more egalitarian attitudes than men do in both spheres. The educational level was significant only in relation to attitudes towards gender roles in the public sphere, and insignificant in relation to attitudes towards gender roles in the private sphere. 


\subsubsection{Determinants of attitudes in two ethnic groups}

In the next step of the analysis, we aimed to find out what characteristics might be influential in the formation of attitudes towards gender roles in both ethnic groups. GLM analyses were performed on both ethnic groups using two sets of independent variables. The results of the analysis are presented in Table 9.5.

As seen in Table 9.5, the attitudes of second-generation Russians concerning gender roles, both in the public and private sphere, are mostly determined by gender. Among Russians, men seem to be more supportive towards traditional gender roles than women are. The attitudes of native Estonians are influenced by different factors. Besides gender, attitudes towards women's roles in the public sphere were determined also by education, career advancement and the economic situation. Attitudes towards gender roles in the private sphere were, besides gender, determined by the place of residence and the economic situation.

As seen in Table 9.5, structural factors had no significant effect on the gender role attitudes of the group of Russians, whereas the attitudes of Estonians were significantly related to structural factors. Thus, our study confirms the results of previous studies that structural factors play a more significant role in the gender role attitudes of the native population than in the attitudes of second-generation immigrants.

Table 9.5 Determinants of attitudes towards gender roles in the public and private sphere by ethnicity, F-values and significance

\begin{tabular}{|c|c|c|c|c|}
\hline & \multicolumn{2}{|c|}{$\begin{array}{l}\text { Attitudes towards women's } \\
\text { roles in the public sphere }\end{array}$} & \multicolumn{2}{|c|}{$\begin{array}{l}\text { Attitudes towards gender roles } \\
\text { in the domestic/private sphere }\end{array}$} \\
\hline & Russians & Estonians & Russians & Estonians \\
\hline \multicolumn{5}{|l|}{ Model I } \\
\hline Gender & $4.942 \%$ & $3.922 \%$ & $4.868 *$ & $4.243 *$ \\
\hline Age & 0.511 & 0.138 & 1.025 & 2.809 \\
\hline Education & 2.323 & $11.373 * \kappa_{*}$ & 0.152 & 0.426 \\
\hline \multicolumn{5}{|l|}{ Model II } \\
\hline Place of residence/city & 0.137 & .542 & 2.990 & $3.644 \%$ \\
\hline Career & 0.148 & $5.689 \% *$ & 1.081 & 0.560 \\
\hline Economic situation & 1.232 & $3.335 \%$ & 0.115 & $4.926 \%$ \\
\hline
\end{tabular}

\footnotetext{
$* \mathrm{p}<.05$

$* * p<.01$

**** $p<.001$

Source: Own calculation based on TIES
} 


\subsection{Conclusion}

The experiences of Western European countries show that understanding gender equality as a concept and principle takes time. This chapter has addressed attitudes towards gender roles in two main ethnic groups in Estonia: second-generation Russians and native Estonians. I have examined the similarities and differences of gender role attitudes, and attempted to analyse the extent to which the differences can be attributed to individual or structural factors.

When comparing gender role attitudes in two attitudinal dimensions among second-generation Russians and native Estonians, it is difficult to find a general pattern. The analysis reveals that second-generation Russians, like native Estonians, have relatively liberal attitudes towards women's roles in the public sphere. The only highly traditional element in the attitude scale was the support of both young Russians and young Estonians for the idea that mothers with young children should not work and stay at home. Unfortunately, the survey did not specify the age of the child under question or the period for how long a mother was expected to stay at home. Accordingly, it was not possible to specify to what extent the responses to the statements were related to attitudes, and to what extent they were related to the highly generous Estonian parental benefit system introduced in 2004 .

The study also shows that, concerning the labour market and public sphere in general, we can speak of a certain equalisation of attitudes among young people with a different ethnic background but the trend of equalisation has yet to touch attitudes concerning the domestic sphere. Moreover, the findings suggest a rather stable support of traditional gender roles in the family - a father's main role still linked to economic issues and that of a mother's to care and motherhood. The findings of the study demonstrate that in spite of relatively small ethnic differences in the actual division of household tasks and responsibilities, there were significant differences in the attitudes on how these tasks should be divided in the ideal case. In both ethnic groups, the socalled 'female tasks' were mostly meant for the mother, whereas the 'male tasks', i.e. tasks related to the financial side of family life, were meant for father. The traditional attitudes, especially concerning support towards the father's role as a breadwinner were more noticeable among Russians, especially among Russian men.

Estonia is one of the post-socialist countries and according to the retraditionalisation thesis, a shift towards more traditional gender roles was predicted in the early I990s. Today we can say that due to democratisation, debates about gender equality and the influence of trends characteristic of Western countries, the return of the male breadwinner family model has not taken place. However, the study reveals that in the 
attitudes of second-generation Russians some signs of longing for the traditional family model and traditional gender roles in the family are still noticeable. In the case of Russians, it is not correct to classify these signs as re-traditionalisation, as in the Soviet Union the male breadwinner model never existed. The more traditional attitudes of Russians towards gender roles in the domestic sphere are similar to the attitudes of native Estonians in the early I990s. While the turn towards family related values among Estonians in the I990s was mostly explained as a reaction to the former Soviet gender contract, the current support for traditional family roles by second-generation Russians could be a reaction to their disadvantaged position in the labour market.

Some researchers (e.g. Bauder 2006) have pointed to the links between immigrants' traditional gender role attitudes and their low success in competing for better positions in the labour market. In the present study, it was not possible to define these links, however, it can be said that more traditional attitudes definitely do not facilitate improvement of the position. Furthermore, the study reveals that Estonian women, especially women with a university-level education, expressed the most egalitarian gender role attitudes, and Russian men expressed the most traditional ones, with Estonian men and Russian women falling in the middle. As previously mentioned, the share of ethnically mixed marriages - usually seen as an indicator of integration - is rather small in Estonia. Thus, there is a possibility that through partner choice and marital behaviour significant differences in the attitudes towards the role of men and women in the family might also play a certain role in the integration processes in Estonia.

\section{References}

Apparala, M.L., A. Reifman \& J. Munch (2003), 'Cross-national comparison of attitudes towards fathers' and mothers' participation in household tasks and childcare', Sex Roles 48 (5/6): $189-203$.

Ashwin, S. (2002), 'The influence of Soviet gender order on employment behaviour in contemporary Russia', Sociological Research 4I: 2I-37.

Barber, J.S. \& W.G. Axinn (1998), 'Gender role attitudes and marriage among young women', The Sociological Quarterly 39 (I): II-3I.

Bauder, H. (2006), 'Origin, employment status and attitudes towards work: Immigrants in Vancouver, Canada', Work, Employment and Society 20 (4): 709-729.

Baxter, J. \& E.W. Kane (1995), 'Dependence and independence: A cross-national analysis of gender inequality and gender attitudes', Gender and Society 9: 193-215.

Bryant, A.N. (2003), 'Changes in attitudes towards women's roles: Predicting gender role traditionalism among college students', Sex Roles 48 (3-4): I3I-I42.

Diehl, C., M. Koenig \& K. Ruckdeschel (2009), Religiosity and gender equality comparing natives and Muslim immigrants in Germany', Ethnic and Racial Studies 32 (2): 278301. 
Eagly, A.H. \& S.C. Chaiken (I993), The psychology of attitudes. Belmont: Wadsworth.

Equality between women and men - 2008, Report from the Commission to the Council, the European Parliament, the European Economic and Social Committee and the Committee of the Regions. Brussels: Commission of the European Communities.

Evertsson, M. \& M. Nermo (2004), 'Dependence within families and the division of labor: Comparing Sweden and the United States', Journal of Marriage and Family 66: 1272I286.

Grönroos, M. \& E. Lorenzen (2003), 'Statistics on gender equality in the Nordic countries: A survey of the status 2002'. Oslo: NIKK.

Hanson, S. \& G. Wells-Dang (2006), 'Gender and attitudes about opportunities in Eastern and Western Europe', European Sociological Review 22 (I): I7-33.

Hirdman, Y. (I99I), 'The gender system', in T. Andreasen, A. Borchorst, D. Dahlerup, E. Lous \& H. Rimmen Nielsen (eds.), Moving on, I87-207. Aarhus: Aarhus University Press.

Hofstede, G. (1980). Cultural consequences: International differences in work-related values. Beverly Hills: Sage.

Inglehart, R. \& P. Norris (2003), The rising tide: Gender equality and cultural change around the world. Cambridge: Cambridge University Press.

Knudsen, K. \& K. Wærness (2008), 'National context and spouses' housework in 34 countries', European Sociological Review 24 (I): 97-II3.

Liljeström, M. (I995), Emanciperade till underordning: Det sovjetiska könssystements uppkomst och diskursiva reproduktion. Turku: Åbo Akademi University Press.

Lück, D. (2005), 'Cross-national comparison of gender role attitudes and their impact on women's life course', GLOBALIFE-Working Paper 67. Bamberg: Bamberg University.

Motiejunaite, A. (2005), 'Labour markets in the Baltic states during economic transition: A gender perspective', in V. Henningsen (ed.), Changes, challenges and chances: Conclusions and perspectives in Baltic Sea area studies, 225-251. Berlin: Berliner Wiss.Verlag.

Motiejunaite, A. \& Z. Kravchenko (2008), 'Family policy, employment and gender-role attitudes: A comparative analysis of Russia and Sweden', Journal of European Social Policy I8: 38-49.

Narusk, A. (I992), 'Parenthood, partnership and family in Estonia', in U. Björnberg (ed.), European parents in the 199os: Contradictions and comparisons, I55-I70. New Brunswick and London: Transaction Publishing.

Narusk, A. (1997), 'Perception of social problems and the 'real' life', in M. Taljunaite (ed.), Everyday life in the Baltic states, 9-24. Vilnius: Lithuanian Institute of Philosophy and Sociology.

Narusk, A. \& I. Kandolin (I997), 'Social well-being and gender: Post-Soviet Estonia and welfare state Finland', Scandinavian Journal of Social Welfare 6: I27-136.

Pajumets, M. (2007), 'One should not exaggerate with daddying: Parental discourses about ignoring the paternity leave benefit', Ariadne's Clew: Estonian Journal of Gender Studies: $49-64$.

Pinto, K.M. \& S. Coltrane (2009), 'Division of labour in Mexican origin and Anglo families: Structure and culture', Sex Roles 60: 482-495.

Riley, S.C.E. (2003), 'The management of the traditional male role: A discourse analysis of the constructions and functions of provision', Journal of Gender Studies I2 (2): 99-II3.

Romero, A.J., I. Cuellar \& R.E. Roberts (2000), 'Ethnocultural variables and attitudes towards cultural socialization of children', Journal of Community Psychology 28 (I): 7989.

Rotkirch, A. \& A. Temkina (I996), 'What does the (Russian) woman want? Women psychoanalysts talk', in A. Rotkirch \& E. Haavio-Mannila (eds.), Women's voices in Russia today, 49-70. Aldershot: Dartmouth Publishers. 
Rotkirch, A. \& A. Temkina (I997), 'Soviet gender contracts and their shift in contemporary Russia', Finnish Journal of Russian and Eastern European Studies - Idäntutkimus 2: 6-24.

Rudd, E. C. (2000), 'Reconceptualizing gender in post-socialist transformation', Gender and Society I4 (4): 517-539.

Shafiro, M.V., M. J. Himelein \& D.L. Best (2003), 'Ukrainian and US American females: Differences in individualism/collectivism and gender attitudes', Journal of CrossCultural Psychology 34 (3): 297-303.

Silver, B.D. \& K.M. Dowley (2000), 'Measuring political culture in multiethnic societies: Re-aggregating the World Values Survey', Comparative Political Studies 33 (4): 517-550.

Soolise võrdõiguslikkuse monitooring. (2005), (Gender Equality Monitoring Research report) Tallinn: Institute of International and Social Studies.

Temkina, A. \& A. Rotkirch (2002), 'Sovetskie gendernye kontrakty i ih transformatsiia v sovremennoi Rossii (Soviet gender contracts and their changes in contemporary Russia)', Sotsiologicheskie issledovaniia II: 4-15. Moscow: Institut nauchnoi informatsii po obshchestvennym naukam.

Temkina, A. \& E. Zdravomyslova (2003), 'Gender studies in post-Soviet society: Western frames and cultural differences', Studies in East European Thoughts 55: 51-6I.

Treas, J. (1993), 'Money in the bank: Transaction costs and the economic organization of marriage', American Sociological Review 58: 723-734.

Treas, J. \& E.D. Widmer (2000), 'Married women's employment over the life course: Attitudes in cross-national perspective', Social Forces 78 (4): I409-I436.

Van der Plight, J. \& N. K. de Vries (1998), 'Belief importance in expectancy-value models of attitudes', Journal of Applied Social Psychology 28: I339-I354.

Vella, F. (I994), 'Gender roles and human capital investments: The relationship between traditional attitudes and female labour market performance', Economica 6I: I9I-2II.

Zdravomyslova, E. (2004), 'Family life in Russia: Hypocrisy and passion', keynote paper presented at the $5 \mathrm{I}^{\text {st }}$ International Conference of ICCFR, Tallinn, I3-I6 June 2004. 


\title{
10 Sense of belonging to Estonia
}

\author{
Gerli Nimmerfeldt
}

\subsection{Introduction}

This chapter will address one aspect of identificational integration by exploring the formation of a sense of belonging to the host country and its society among second-generation Russians in Estonia, based on the connection and emotional attachment to the host country and feelings of being part of the society. The innovation of the chapter is in providing an additional operationalisation of identificational integration, which differs from traditional approaches applied in empirical studies.

The studies of identificational integration of immigrants and their descendants based either on the linear or segmented assimilation theory or on their elaborations, have mostly focused on ethnic self-identification and the processes by which it is retained or rejected (Gans I979; Alba I990; Waters I990; Esser 2004; Heckamm \& Schnapper 2003; Portes \& Rumbaut I996, 200I). In the European context, for some immigrant groups, the religious identity, instead of ethnicity or together with it, is seen as one of the major indicators of identificational integration (Buijs \& Rath 2006; Foner \& Alba 2008). Another aspect often included in these studies is national identity formation, where the identificational integration is assumed to lead to the creation of a shared national identity, which requires certain commonalities, such as a shared language and core cultural values (Heckmann 2003). Besides looking at ethnic and national identifications, one can notice the rising interest in local collective identities, mainly at the level of residence city, as a possible source for the feeling of belongingness among the second generation (Kasinitz, Mollenkopf \& Waters 2002; Groenewold 2008; Schneider \& Stojčić 2008).

The most common definition of identificational integration in recent studies departs from the one proposed by Heckmann and his colleagues (Heckmann \& Schnapper 2003: 10; Bosswick \& Heckmann 2006: IO). They understand identificational integration as membership in a host society at a subjective level, indicated by the formation of feelings of belonging to and identifying with different groups in society, particularly ethnic, regional, local and national groups. Operationalisation of the identificational integration remains, in most cases, at the level of 
categorical identity measurement, giving information about self-categorisation into different groups in society. Since the focus is mainly set on ethnic and national groups, the result is often an evaluation of integration at the identity level through classification of immigrants and their descendants according to whether they identify only with their ethnic group, the titular group or feel affiliated with both. Thus, at the national level, identification with the majority group is measured by asking about the sense of belonging to the titular group of the respective host society.

However, a previous study based on quantitative and qualitative data on second-generation Russians in Estonia demonstrated that the national identity category labelled 'Estonian' is mainly understood as a reference to ethnicity and much less to the other aspects expected to be connected to identification at the national level. This is why the part of identificational integration that involves the formation of a sense of belonging to the host country and society cannot be measured by using self-identification with the pre-determined category of national identity labelled as the titular group in society, at least not in the context of Estonia (Nimmerfeldt 2009).

This chapter posits an enhanced approach to identificational integration, based on an understanding that in addition to one's self-identification with society's different groups, the formation of attachment to the host country and society should also be examined as indicators of the sense of belonging at the national level. The measurement of identificational integration proposed here puts greater emphasis on the sense of belonging, based on feelings of being at home in their country of residence and feelings of being accepted and being part of its society. Both aspects of belonging are crucial for social cohesion in society and, at a more personal level, for the psychological well-being of the second generation.

The aim of this chapter is to examine the possible objective and subjective level factors that influence the sense of belonging to Estonia. First, the choice of two sets of hypothetical factors related to both country and culture of origin and to host country, is explained referring to literature and previous studies conducted on Russians in Estonia. Next, a binary logistic regression analysis is carried out in order to estimate the impact on the formation of a strong sense of belonging of the following factors: citizenship status, close relations with Estonians, experienced and perceived discrimination, perceived threat to cultural identity, transnational ties and activities, emotional connectedness to the kin state and the strength of ethnic identity. Additionally, the impact of these factors is examined for the parental background and country-specific human capital, as well as personal socio-demographical characteristics and indicators of the level of structural integration and acculturation. 


\subsection{Theoretical framework}

Mark Thomson and Maurice Crul's (2007: 1034) introduction to their Journal of Ethnic and Migration Studies special issue on the second generation in Europe admits that in both the United States and Europe, discussion about the second generation so far has been dominated by indicators of structural integration, i.e. their position in education and the labour market. Another frequently targeted dimension of integration is the acculturation process, which is seen as one of the premises for structural integration. The fact that the emphasis is mainly on structural integration and acculturation processes stems, largely, from the theoretical frameworks employed for conceptualising integration, by which socio-economical mobility is considered to be of major importance in adaptation processes.

This chapter demonstrates that studying the integration of immigrants in society by only looking at their belonging to the host society through formal and legal bonds and participation in its core institutions means that an important part of the adaptation processes is left out of focus. Because formally being a part of society does not always mean being a full member of that society, there are several informal and symbolical barriers to being recognised and accepted as true and full members. However, the feeling of belonging - the feeling of being at home and being accepted by and part of society - is important in the respect of unity in society, as well as at a more personal level, for the psychological well-being of immigrants and their descendants.

In the case of the latter, it is too often assumed that the bare fact of being born and growing up in the country and going through the socialisation processes in the society is enough to create attachment and a sense of belonging to the host country and its society. Only major shocks in society caused by riots among immigrants' descendants (Britain in 200I, Paris in 2005, Estonia in 2007 and Copenhagen in 2008) bring the subject of belonging into the spotlight in public discourse and into the minds of politicians. At this point, an urgent need for promoting community cohesion becomes clear to everybody. These kinds of riots are then followed by stressing the importance of a common identity shared by all residents as a solution for the lack of social unity. Estonia is no exception. The reaction of the Estonian government to the riots in April 2007 was similar to the one in Britain, where it was stated that they need to 'foster social unity by rehabilitating the importance of being British' (Home Office 2005, quoted in Uberoi 2007:I42). In the light of reassessment of the approach toward integration that took place in society after the events related to the removal of the Bronze Soldier statue, the need for a shared sense of national identity among all residents in Estonia was stated explicitly as one of the 
main aims of the new integration strategy. According to Estonian Integration Strategy 2008-20I3, the ultimate goal of integration in Estonia is a 'culturally diverse society with a strong Estonian state identity'; further on in the text the objective is specified: 'to support the shared feeling of belonging in Estonian society among all permanent residents through sharing common values and knowledge of the national language' (EIS 2008: 3).

No one doubts that at least on some level social unity and cohesion are necessary for a society to operate and many claim that cultural diversity is a heavy challenge to achieving that unity. What is meant by social unity? It is a reciprocal attachment: individuals and groups comprising a society should feel attached to each other and attached to the society (polity) that they all comprise. Attachment, in turn, cannot be cultivated without feelings of security and belonging. To become attached to a society, a person needs to feel welcomed and respected as a part of the whole. Based on these feelings, the sense of belonging will be developed and reflected in the desire to consider and call the place home (Uberoi 2007: I44).

Previous research has demonstrated that a sense of belonging plays an important role in a positive self-image but also in the formation of positive attitudes towards others and building trust towards them (Arredondo I984, quoted in Chow 2007: 512). Attachment to the country and society at the national level also increases political interest and involvement, including voter turnout (Huddy \& Khatib 2007: 65).

One of the psychological challenges faced by immigrants is the feeling of not belonging anywhere. As Roy F. Baumeister and Mark R. Leary (I995) claim, the need to belong, that is, to form and maintain social attachments is a fundamental human need. They illustrate that belonging has multiple and strong effects on emotional patterns and cognitive processes. Furthermore, a great deal of human behaviour, emotion and thought is caused by this fundamental interpersonal motive and a lack of attachments is linked to a variety of ill effects on health, adjustment and well-being.

While first-generation immigrants might preserve the attachment to their country of origin and hold on to interpersonal relationships formed in the homeland, for the second generation, this alternative for creating social bonds and, thus, the needed sense of belonging through attachment to their country of origin is often not feasible or desirable. Therefore, the danger of not belonging to any country and the feeling of being in-between the host country and their parents' country of origin might be even more relevant for immigrants' descendants.

If there is an ethnic community of credible size in the host country that is coherent enough to provide the second generation with the sense of belonging and social, economical and psychological support, then the 
danger of belonging nowhere and the following sense of insecurity and identity crises are diminished. It has been argued that Russians do not form a coherent ethnic community in Estonia. Instead, the Russian community in Estonia is considered too heterogeneous and fragmented, missing a uniting minority identity (Vihalemm \& Masso 2003; Laitin I998; Kolstø I995; Vihalemm \& Kalmus 2009). Therefore, in the case of second-generation Russians in Estonia, the feeling of belonging nowhere could be anticipated as a relevant challenge, making the feeling of belonging to the wider society psychologically even more important.

\subsection{Operationalisation of the sense of belonging}

In accordance with the traditional operationalisation of identificational integration, identity is explored via self-categorisation in the TIES survey. Identification with different groups is measured by asking a question about the intensity of feelings of belonging simultaneously to a variety of identity categories. Thus, at the national level, identification with the majority group is measured by asking for a youth's sense of belonging to the titular group of the respective host society. The underlying assumption here is that feeling of belonging to a national identity category reflects the sense of belonging to the host society and country. Previous analysis of TIES data showed that second-generation Russians mostly do not identify themselves with the category labelled as the titular group (45 per cent of respondents reported no feelings at all of belonging to that category). A follow-up qualitative study revealed that the reason for this was the fact that the national identity category, in essence, really denotes ethnic identity in the context of Estonia. Consequently, the part of identificational integration that involves the formation of a sense of belonging to the host country and society cannot be measured by using self-identification with a pre-determined category of national identity labelled as the titular group in society (Nimmerfeldt 2009).

Next, the additional instrument used for measuring the sense of belonging to Estonia among second-generation Russians is presented. The instrument emphasises the emotional attachment and connection considered an important basis for social unity in society. The sense of belonging to a host country and its society is measured by a block of seven statements on different aspects of connectedness to Estonia. First, the statements cover the emotional attachment to the country of residence indicated by the intention to stay and consider it the homeland, plus a more direct statement about loving the country. Second, the block includes statements on the feeling of being part of society and 
being accepted as its member. The third aspect measures the feelings of closeness with the majority group in society.

During the adaptation process of the TIES survey instrument into the Estonian context, a set of statements on the aforementioned three aspects was formulated. A pilot survey for testing identity questions including statements on the connection to Estonia was carried out among 98 Russian students at Tallinn University. Based on the factor analysis of the pilot study results the following seven statements were chosen for inclusion in the final survey instrument:

a) 'I love Estonia'

b) 'I feel that I am part of Estonian society'

c) 'I consider Estonia my homeland'

d) 'I would gladly leave Estonia and settle elsewhere'

e) 'I am proud of the achievements of Estonians'

f) 'I have nothing in common with Estonians'

g) 'I feel unwelcome in this country'.

The respondents' level of agreement is specified on a typical five-level Likert scale, from 'strongly agree' to 'strongly disagree'. Based on these seven statements, a new variable is composed for measuring the strength of the sense of belonging to Estonia. ${ }^{\mathrm{I}}$ The result is an index with values from 7 to 35, which are collapsed together into four categories indicating the sense of belonging from very weak to very strong. ${ }^{2}$ The four categories are further collapsed into two and the resulting dichotomous variable is used in further analysis as a dependent variable, aiming to explore the possible sources for the formation of a stronger sense of belongingness to Estonia.

According to this composed variable, i2 per cent of Russian respondents feel a very strong and 42 per cent a strong connection to Estonia, while 35 per cent feel weakly connected and II per cent very weakly connected. The next sections of this chapter will review the literature and previous empirical studies in order to pose a hypothesis about what objective and subjective level factors might have an impact on the formation of a stronger sense of belonging and then to test these by a logistic regression analysis.

\subsection{What influences the sense of belonging?}

In the literature, several factors are pointed out that are related either to a wider social and political context, to a more immediate local environment, a social network and a family or to personal socio-demographic characteristics, presumably having an impact on integration processes in general or more specifically on identificational integration and 
psychological adaptation. Second, the identity formation of immigrants is considered to be influenced by factors related to both their country of residence and its society, as well as by their country of origin and their identification with an ethnic group. Next, an overview of the factors expected to be relevant for the formation of a sense of belonging to a host country and its society is drawn both from literature and from previous empirical studies, including the qualitative study conducted with second-generation Russians.

\subsubsection{Citizenship}

One principal basis for solidarity and social unity is citizenship. Citizenship denotes membership to a political and geographic community and it encompasses legal status, rights, political and other types of participation, as well as a sense of belonging (Bloemraad, Korteweg \& Yurdakul 2008: 153). Therefore, many believe that formal membership is followed by the sense of belonging to that community. Parsons argues that a shared sense of citizenship must be sufficiently powerful to override the divisive potential of ethnic group allegiances and, thus, could serve as a way to prevent ethnic conflict and marginalisation (quoted in Kivisto 2004: 29I). Civic incorporation, together with accompanying civic identity, is seen as one solution to ethnically and culturally diverse societies, also by multicultural theorists such as Charles Taylor (1992), Will Kymlicka (1995) and Bhikhu Parekh (2000). They emphasise civic assimilation instead of structural assimilation, which is almost automatically followed by cultural and identificational assimilation. They claim that civic incorporation through citizenship as an overarching mode of identity might provide a sufficient basis for common culture and, thus, societal cohesion (Kivisto 2004: 293).

The immigrants' readiness to become naturalised has traditionally been used as a measure of their sense of belonging to the host society (Chow 2007: 513). Acquisition of citizenship is supposed to encourage individuals to internalise national norms and values, as well as allow them to mix with the general population (Schnapper, Krief \& Peignard 2003: I6). On the other hand, behind the decision not to acquire citizenship are reasons like continuing identification with the country of origin, its culture, language and religion, as well as the preservation or development of a sense of national pride. In addition, more practical reasons are given, such as legal bonds and pressures from the country of origin. Last, but not least, this disinterest is also considered a reaction to the rejection experienced by immigrants and their descendants in host countries (Kurthen I995: 932).

Recent studies conducted in Estonia provide some proof that emotional attachment to Estonia is stronger among Russians with Estonian 
citizenship, compared to those without any citizenship or with Russian citizenship. Using a survey question about the sense of belonging to the Estonian people in the constitutional sense, Marju Lauristin (2008) demonstrates that among Estonian citizens the feeling of belonging to the Estonian people is much stronger compared to people with undetermined citizenship and Russian citizens.

At the same time, the follow-up interviews done with Russian youths who are born and have lived their whole life in Estonia revealed that by the second generation the fact that they needed to go through the naturalisation process is sometimes perceived as insulting. Consequently, a component variable is used for further analysis, one that differentiates within the Estonian citizens' category according to the way Estonian citizenship has been acquired - either by birth or through a naturalisation process $^{3}$.

\subsubsection{Discrimination}

One of the challenges confronting the second generation is that of the hostile social environment in host countries. Experiences and perceptions of discrimination and hostility on the part of majority group in society have been one of the most common factors anticipated and empirically proved to have a major impact on an immigrant's identity construction. The relationship has usually been demonstrated to be negative: leading to reactive differentiation from the majority and distancing from mainstream values, norms and institutions. This kind of distancing is considered to be accompanied either by a strengthening in ethnic identification, which leads to segregation, or identification with an opponent subculture (Rumbaut I994; Portes \& Rumbaut I996, 200I; Berry, Phinney, Sam \& Vedder 2006). Accordingly, we expect those who have experienced discrimination and/or who perceive their ethnic group as being discriminated against to be less likely to feel a strong sense of belonging to a host country and its society.

Experiences of discrimination are measured through two questions: I) whether the respondent has ever experienced hostility or unfair treatment on the basis of ethnicity, either as a child or later in life; 2) whether the respondent has ever been offended because of their ethnicity. For measuring perceived discrimination, there is a question about how often, according to the respondent, Russians experience hostility or unfair treatment because of their ethnicity or descent in Estonia.

\subsubsection{Perceived threat on cultural identity}

Next, we expect the sense of belonging to a host country and its society to be affected by the perception of policies, public discourse and 
majority attitudes in respect to minority integration in Estonia. The hypothesis anticipates the sense of belonging to be less strong among second-generation Russian youths who perceive assimilative pressure from the part of state and the majority group in society, compared to those who do not perceive a threat to their cultural identity through assimilation. The hypothesis about the impact of a perceived threat of assimilation stems from the reactive identity approach. This seeks to explain the dialectics of assimilation and confrontation in identity construction processes and was first elaborated for the studies of public opinion towards EU integration (Vetik, Nimmerfeldt \& Taru 2006). It was later refined for studying the interethnic relations and integration processes of second-generation Russians in Estonia (Vetik 2006; Nimmerfeldt 2006).

The theoretical basis for the definition and operationalisation of the concept of reactive identity is based, on one hand, on the semiotic ideas of Lotman (I999, 200I) and Benveniste (2003) and, on the other hand, on the social identity theory (Tajfel I98I; Tajfel \& Turner I979) and Jenkins' (2004) social-psychological approach to identity, as well as on sociological research on reactive ethnicity conducted by Portes and Rumbaut (I996, 200I).

In the reactive identity approach, the concept of identity is understood as subjectivity formed in the process of constructing an 'us-them' relationship. The concept is defined as a boundary between 'us' and 'them', constructed in a dialogue with the 'other' based on two processes: identification with the 'other' and differentiation from the 'other'. Both processes are part of identity construction. An imbalance between these two processes in the self-other relationship will be perceived by people as assimilative or separative pressure, resulting in the emergence of a reactive counter identity, i.e. confrontation with the 'other'. Reactive identity emerges in situations where individuals perceive either dominance of identification with the 'other', i.e. assimilative pressure or dominance of differentiation from the 'other', i.e. separative pressure (Vetik, Nimmerfeldt \& Taru 2006: I08I-I083). Reactive identity represents a counter reaction to these kinds of imbalances and is expressed in confrontation with the 'other' and will result in an even stronger boundary between 'us' and 'them'.

For testing the hypothesis about the assimilative pressure and reaction to it, in the form of a weaker sense of belonging, we used a composed variable based on four statements about the perception of a threat on cultural identity:

a) 'Learning Estonian makes one distant from Russian culture'

b) 'Maintaining Russian culture in Estonia is at risk'

c) 'I don't feel any pressure to give up Russian culture and replace it with Estonian'

d) 'There is room for a variety of languages and cultures in Estonia'. 
The level of agreement was specified using a five-level Likert scale (from strongly agree to strongly disagree). Based on these four survey items, an aggregated variable is computed. ${ }^{4}$

\subsubsection{Interethnic relations}

The fact that interethnic relations are considered to play a role in the formation of attachment to the host country and its society stems from the so-called 'contact hypothesis'. According to this, close and continuous contact with out-group members promotes positive and tolerant attitudes toward that group (see Schulze in this volume). Previous studies done in Estonia support this hypothesis and have clearly demonstrated that personal close contacts (at the level of family or friends) are the most important factors affecting the attitudes towards the other group (Valk \& Karu I997; Korts 2009; Korts \& Vihalemm 2008; Schulze 2008). Hence, the hypothesis for analysis is that Russian youths who have Estonians among their circle of friends in general and, specifically, among their three best friends feel a stronger sense of belonging to the society, compared to second-generation Russians who have no close contacts with Estonians.

\subsubsection{Transnational ties and feeling connected to the country of origin}

Widening access to transportation and digital communications technologies has transformed the relationship between space and place, so that travel and mobility are no longer prerequisites for engaging with and being influenced by the world views and opinions of people in geographically distant locations (Haller \& Landolt 2005: II83). As a result, novel possibilities for global, multi-local and transnational modes of membership and types of identities arise. Increasingly, aspects of social life take place across borders, even as the political and cultural salience of nation-state boundaries remains clear. Several studies have shown that migrant families orient significant aspects of their lives around their country of origin by keeping in touch with family members, relatives and friends who live there. They travel as tourists and send or receive remittances. Additionally, they follow the media of their country of origin and they engage in transnational collective action, religious, civic and political institutions (Guarnizo, Portes \& Haller 2003; Haller \& Landolt 2005). These kinds of transnational actions have led many people, including migration scholars and policymakers, to assume that the integration of immigrants and their descendants has failed. Instead of integrating into the host society, migrants are believed to prefer living in a sort of transnational social space in which the language, culture and social contacts of their homeland are cherished (Lucassen 2005: 
I66). Thus, to this extent, transnational ties challenge the conventional notions about the assimilation of immigrants into host countries.

Most scholars of transnational migration today recognise that many contemporary migrants and their offspring maintain various kinds of ties to their homelands while also becoming incorporated into the countries where they have settled (Levitt \& Jaworsky 2007: 130). An increasing number of migrants are orienting their lives to two or even more societies; they develop transnational communities and consciousness (Castles 2002: II46). The mobility and belonging to more than one place is now seen as complementary instead of being contradictory. Sustained ties with two or more countries are regarded as an integral, and potentially beneficial, part of the migratory experience (Gustafson 2005: 8), instead of being an anomaly.

Because of Russia's proximity to Estonia, it is assumed that transnational activities like these are frequent among Russians. Many of them have family members and relatives living there and many travel there frequently either for work or business. However, whether visits and staying in the country of origin increase or decrease the sense of belonging to the host country and its society depends on the nature of the experiences had while there. Positive experiences of a sense of belonging with ethnic peers, and of being accepted as a member of a group while staying there, might strengthen the ethnic identity and weaken the sense of attachment to the host country. This is especially so if such positive experiences in the country of origin are collated with negative experiences of inacceptance, hostility and discrimination in the host country. At the same time, visiting the country of origin might be a catalyst for a revaluation of circumstances in the current residence country. This might occur via a comparison of living conditions, political, economical and social environments. It may also highlight the cultural similarities with the majority in the host country and differences with the members of one's ethnic group living in the country of origin. During the follow-up interviews conducted with second-generation Russians, several interviewees expressed their disappointment and dislike of the living conditions and social-political arrangements in Russia, and most of them felt that they are also culturally different from Russians in Russia. Some mentioned being treated like outsiders, some even like traitors. Consequently, we can hypothesise the association between transnational ties and the sense of belonging to the host country to be in either direction.

Two measures of personal experiences of visiting Russia are used: frequency of visiting Russia in the past five years and time spent in Russia altogether during these visits. Additionally, we use the following different media channels as an indicator of whether the respondent lives in a Russian or an Estonian communication field. Media 
consumption is measured by a composed variable, which is based on two questions asking about how often the Russian and Estonian language TV stations are followed. Emotional attachment and the feeling of connection to Russia are measured by three items indicating diasporic identity aspects: the intention to move to Russia; considering Russia the homeland; and the strength of feeling a connection to Russia.

\subsubsection{Ethnic identity}

In mainstream integration and assimilation theories, immigrants' identificational integration is generally considered to be related to ethnic and national self-identifications. The process is referred to as a decline in ethnic identities and loyalties accompanied by a growing identification with the majority group and the host state among the descendants of immigrants. Such an identificational assimilation is expressed by the change in the nature of ethnic identity, which turns to an optional, familial, leisure time form of symbolic ethnicity (Gans I979; Alba I990; Waters I990). This decline in ethnic identity is considered to be followed by the formation of a self-image as an unhyphenated or hyphenated member of the host society. Thus, by adding a constructed index of the strength of ethnic identity into the regression model, we will test the hypothesis of these theories about whether the weak ethnic identity is supplemented by a strong sense of belonging to the host country and its society.

The strength of ethnic identity is measured through five statements about ethnic pride, attachment and commitment to one's ethnic group and its common cultural practices:

a) 'Being a Russian is an important part of myself'

b) 'I see myself as a real Russian'

c) 'When somebody says something bad about Russians I feel personally offended'

d) 'I often wish to conceal the fact that I am a Russian'

e) 'It is important to me to know Russian history, culture, customs and traditions'.

Based on these five statements, an index is composed for further analysis. $^{5}$

\subsubsection{Parental background}

It has been argued that identificational assimilation is shaped, largely, by family context and demonstrated the effect of parental ethnic socialisation, social status and parent-child relationships (Rumbaut 1994). Our data allows us to test the impact of social status (highest completed 
educational level and occupational group held at the respondents' age of fifteen) and the more country-specific human and social capital of parents (proficiency in Estonian and citizenship status). The hypothesis for this part is stated as: Russians with parents of higher social status and country-specific capital are more likely to feel a stronger sense of belonging to Estonia and its society. In addition, the parents' descent is taken into account as well, with the objective of checking whether second-generation youths with one parent born in the host country feel a stronger connection to Estonia compared to youths with both parents born outside the country.

\subsubsection{Socio-demographic characteristics}

Mainstream integration theories assume the relevance of several sociodemographic characteristics for the formation of a sense of belonging. Including personal characteristics like the respondent's titular language proficiency, highest level of education completed, employment status and occupational group into the analysis tests the hypothesis drawn from classic theories about the acculturation and integration into the main structures of society being followed more or less automatically by a formation of the sense of belonging.

Some previous studies done on the second generation have suggested that self-identification is a gendered process (Rumbaut I994) and that is why the respondents' gender is also included among other personal characteristics. Last, but not least, age as a categorical variable (I8-25 years old and 26-35 years old) is included in the model as a control variable.

The city of residence is included into that block to test the general hypothesis about the contextual impact on identity formation. Previous research has proved the city of residence to be significantly related to the identification processes (see Porter \& Rumbaut 200I; Schneider \& Stojčić 2008; Nimmerfeldt 2008a). Based on the concentration of Russians in Ida-Virumaa cities, including Kohtla-Järve, compared to the situation in Tallinn (see Sokolova in this volume), we can assume that the city of residence has either a direct or an indirect effect on the attachment of second-generation Russians to Estonia and Estonians. Since in Tallinn the minority-majority patterns are more strongly established because of the demographical situation, while in Kohtla-Järve the ethnic differences are not as pronounced in everyday life, the city of residence might have an indirect effect on the sense of belonging through other hypothesised factors like discrimination, the strength of ethnic identity and the perceived threat on cultural identity. On the other hand, because of the geographical proximity of Kohtla-Järve to Russia, the city of residence might also be associated to the feelings of connection 
through the transnational activities and ties to Russia. However, a direct impact of the location on the connectedness might also be expected. A previous qualitative study has unveiled shocking facts about the sense of belonging to Estonia among Russian inhabitants in this region. In the focus group conducted in Narva, some participants drew a clear distinction between 'their' city (and Ida-Virumaa in more general) and the rest of Estonia, especially Tallinn, pronouncing point-blank that 'Narva is not Estonia'. In response to the moderator's question specifying what then comprises Estonia, the respondents said that 'Estonia is out there, in Tallinn and elsewhere’ (Vetik \& Nimmerfeldt 2008a).

\subsection{Results of the analysis}

In order to explore to what extent the possible factors expected, either on the basis of theories or the results of previous empirical studies, have an effect on the formation of the sense of belonging in the case of second-generation Russians, a two-step logistic regression analysis was carried out. The binary logistic regression model (Appendix IO.I) run in the first step includes variables measuring the citizenship status, experienced and perceived discrimination, perceived threat on cultural identity, close interethnic relations, transnational activity, emotional attachment to Russia and the strength of ethnic identity. The analysis looks at the odds of feeling a strong connection compared to a feeling of weakly belonging to Estonia.

The results of the analysis prove only two of the factors - the perceived assimilative pressure and aspects of diasporic identity - to be significantly associated with the formation of a strong sense of belonging to Estonia among second-generation Russians.

Considering all the possible factors, the perception of threat on one's cultural identity has the greatest impact on the chances of feeling a strong belonging to a host country and its society. The chances of feeling strongly connected to Estonia are 8.83 times greater for those second-generation Russians who do not perceive a threat on their cultural identity, compared to those who do perceive this kind of a threat. Although remarkably less (2.96 times) yet still significant, the odds of a strong sense of belongingness increased in the cases of respondents who had not perceived any assimilative pressure, compared to those who have perceived a threat on their cultural identity.

Second, the diasporic identity - considering Russia the homeland and intending to go to live in Russia - significantly lowers the odds of feeling a sense of belonging to Estonia. For respondents who certainly do not intend to move to Russia in the future, the odds of feeling strongly connected to Estonia are 2.32 times higher compared to those 
who maybe or certainly consider moving to Russia. An even stronger association is shown between the sense of belonging to Estonia and considering Russia the homeland. The odds of feeling strongly connected to Estonia are 3.33 times higher for those respondents who do not consider Russia their homeland compared to those who do.

In the case of emotional attachment to a parent's country of origin, we cannot claim causality based on our survey data because the identification with Russia could also be a reaction to the lack of sense of belonging to Estonia. Concerning the effect of a perceived threat on cultural identity, we can rely on the reactive identity approach and explain the result by referring to policies and public discourse. Since regaining independence, discourse in Estonia has been dominated by legal restorationism and this has transferred further into the integration policies with an emphasis on 'Estonian cultural predominance' (Pettai \& Hallik 2002). Previous studies also indicate that Russians perceive the Estonian integration policy as forced 'assimilation' (Vetik 2006, 2008), which expects them to adapt to a society dominated by Estonian language and culture. Estonia's language policy is regarded as a threat to the survival of the Russian language in Estonia (see Vetik in this volume), and the ongoing school reform is seen not as an attempt to equalise the opportunities for everyone in society but rather, as a threat to the Russian youth's cultural identity (Saar 2008; Proos 2006).

However, the included result of no significant impact of other factors on the odds of having a strong sense of belonging is no less important than the affirmative results. First, the logistic regression analysis shows us that second-generation Russians' citizenship status or the way Estonian citizenship has been acquired plays no significant role. Previous studies focusing on the integration of Russians in Estonia have also proved that citizenship status is more of a pragmatic choice and not directly dependent on a person's civic identity. Based on the data of Integration Monitoring, Lauristin (2008) argues that acquiring Estonian citizenship is not related to political or civic identification but is, instead, a sort of social investment. At the same time, the results of Integration Monitoring also show that the emotional attachment to Estonia is not determined by the citizenship status alone: 66 per cent of Russians with Estonian citizenship consider Estonia to be their homeland, but I4 per cent consider their homeland to be Russia (20 per cent consider both Russia and Estonia as homelands), while 48 per cent of people with undetermined citizenship and 20 per cent of respondents with Russian citizenship also consider Estonia their homeland (ibid.). Similar results indicating that citizenship status and belonging to one's homeland do not overlap were shown by previous monitoring on integration in Estonia (Hallik 2006). 
Furthermore, it is not possible to interpret the undetermined citizenship status, in terms of choice, as not being related to a host state in the context of Estonia. Former empirical studies have proven that there are several reasons for Russians' stateless status. First, the strict requirements of the citizenship policy, mainly the Estonian language exam, hinder the naturalisation process. According to recent survey results, nine out of ten Estonian and Russian respondents considered the inability to learn Estonian one of the main reasons why there are still so many people without Estonian citizenship living in Estonia (Nimmerfeldt 2008b). A qualitative study among individuals with undetermined citizenship conducted in Tallinn and cities in Ida-Virumaa indicated that besides a lack of knowledge of the Estonian language, the more practical aspects related to everyday life are equally important arguments for retaining an ambiguous legal status. On one hand, it is easier for immigrants without Estonian citizenship to travel to Russia compared to Estonian citizens; on the other hand, the lack of Estonian citizenship often poses no problems for living in Estonia (Vetik \& Nimmerfeldt 2008b). The survey results of Integration Monitoring 2008 support these conclusions: 72 per cent of Russian respondents state that the facility of travelling to Russia is one of the reasons why Russian speakers do not seek Estonian citizenship; and 75 per cent think that the cause can also be found in the fact that being without citizenship does not hinder their lives in Estonia.

When it comes to discrimination, our results indicate that having experienced unfair treatment or being offended on the basis of ethnic origin does not decrease the odds of feeling a strong belonging to Estonia. Similarly, the perceived discrimination of Russians in Estonia does not prove to have an effect on the odds of Russian youth feeling that they belong to Estonia, when all other variables are taken into account. The most probable reason for such results might be in the few frequencies of reported discrimination experiences because of ethnicity among Russian respondents: 3 per cent said they had experienced hostility or unfair treatment because of their ethnicity regularly; and 9 per cent occasionally. Only I per cent has been offended on the basis of their ethnic origin regularly and 7 per cent occasionally. Although most of the respondents report never having experienced hostility personally, they do perceive the level of discrimination against Russians in Estonian society to be high. According to half of all respondents, Russians experience frequent hostility or unfair treatment, regularly or occasionally and only I3 per cent think it never happens. In addition, Integration Monitorings have indicated that the perception of discrimination at the group level is much higher than in personal experiences.

The analysis does not support the 'contact hypothesis'. Having Estonians among current friends in general, or among three best 
friends in a narrower sense, plays no significant role in the probability of feeling a strong sense of belonging to Estonia. Here, one of the explanations might lie in the fact that the questions used for measuring interethnic relations do not reflect the contacts between two groups in the best way, the first question being too general and the second too narrow. Another explanation for interethnic contacts appearing not to be associated with feelings of belonging might be the shortage of close contacts between the two groups, which leads to a situation where attitudes are formed based on perceptions held by a person's ethnic peers.

According to the TIES survey data, 38 per cent of Russian respondents reported to have no ethnic Estonians among their current friends, 29 per cent had only very few and 25 per cent reported some friends to be Estonians. Therefore, only 6 per cent of Russians interviewed have many Estonian friends and 2 per cent said that most of their friends are Estonians. Previous research has also revealed that interethnic contacts among Estonians and Russians in Estonia are relatively sparse and mainly rather sporadic, involving occasional contacts in shops, on the street or on public transport. The few relationships reported between the two groups generally remain instrumental, work and study related (Korts 2009: I27; Korts \& Vihalemm 2008: I). It may be the case that contacts with colleagues or fellow students were reported as friendships, which ordinarily is hypothesised to increase the sense of belonging, but in fact does not translate into close bonds between the two groups.

Descriptive data from the TIES survey show that second-generation Russians seldom report having ethnic Estonians among three best friends - among 72 per cent of respondents none of the three best friends is Estonian. Due to a lack of close personal contacts, the sense of belonging to Estonia and among Estonians is more likely to be affected by the overall public discourse, reflected by the media or prevalent among the personal circle. Külliki Korts (2009: 135) has shown in her recent study on Russian youth that the widespread perception (or fear) of a lack of respect from the majority group is of crucial significance to intergroup relations and attitudes towards the 'other'. This is not based on personal experiences but rather, taken directly from public discourse or based on attitudes held by peers and family members.

Based on the TIES survey data, 4I per cent of Russians interviewed have never been to Russia, 23 per cent have been there once and I 6 per cent twice during the last five years. More frequent visits are much less represented. The visits to Russia are mostly of short duration, lasting between one and three weeks, and with the aim of visiting family or taking a holiday there. According to logistic regression analysis, the frequency of visits has no impact on second-generation Russians' feeling 
of belonging to their country of residence. Similarly, the time spent in Russia does not play a role.

There is also no support for the implicit hypothesis of many integration theories, which assume weak ethnic identity predicts a strong sense of belonging to the host country and its society, instead of a strong identification with one's ethnic group. Variation in the strength of ethnic pride and attachment is not reflected in the different levels of the sense of belonging to Estonia. This indicates that feelings of not being part of the society are not necessarily accompanied by a stronger border drawn between one's ethnic group and the majority. In other words, feelings of belonging to both the ethnic group and to the host society are not mutually exclusive. Whether the feeling of not belonging to either really means that there is a feeling of belonging nowhere and what the other possible groups are which serve as substitute sources for feelings of belonging is a task for further analysis.

None of the hypotheses related to the respondents' parental background found support: for Russian youths with both parents born outside of Estonia, the odds of feeling a strong sense of belonging to Estonia did not decrease compared to youths with one parent born in Estonia; the odds are also not increased by the parents' higher social status and country-specific human capital.

Among personal socio-demographic characteristics, only the respondent's age has some significant impact on the sense of belonging to Estonia - specifically, for those who belong to a younger age group (I825). Their chances of feeling strongly connected are 2.5 times fewer, compared to Russian youths aged 26-35 (Appendix IO.I). However, the indicators of acculturation (proficiency in Estonian) and structural integration (educational level, employment status and occupational group) do not explain the formation of a sense of belonging to Estonia. The process is neither gendered, nor locally context-based at the city level. Besides, adding parental and personal background variables into the regression model does not reduce the strong effects of perceiving a threat on cultural identity and feeling emotionally attached to Russia (Appendix IO.I).

\subsection{Conclusion}

The focus of this chapter has been on one aspect of identificational integration: the sense of belonging to a host country and its society, with an aim to demonstrate why it is an important aspect of identificational integration of the second generation. Conceptually, the formation of a sense of belonging could be connected to different groups in society, including ethnic, religious, regional, local, national, transnational and 
supranational groups. Instead of looking at all possible bases available for identification and relevant for second-generation Russians in Estonia, this chapter examined the sense of belonging at the national level. The purpose was to present an additional way to approach the identificational integration and to present an operationalisation that, instead of looking at self-identification with different identity categories, emphasises emotional attachment to the host country and society, indicated by the feelings of being at home and part of the society. Thirdly, based on both the TIES survey data and the qualitative follow-up study, this chapter explored the possible sources and obstacles for the formation of the sense of belonging to Estonia among second-generation Russians. The impact of several objective and subjective level factors was tested by carrying out a two-step logistic regression analysis.

The analysis proves only two of the factors - the perceived assimilative pressure and the aspects of diasporic identity - to be significantly associated with the formation of a strong sense of belonging to Estonia. Taking all the possible theoretical, personal and parental background factors into account, the greatest impact on the chances of feeling a strong sense of belonging to Estonia relates to a lack of perception of threat on the cultural identity. Second, the diasporic identity - considering Russia as the homeland and having the intention to return to Russia - significantly lowers the odds of feeling a sense of belonging in Estonia.

Thus, the main conclusion is that the principal obstacle for a shared sense of belonging among second-generation Russians is the perceived assimilative pressure from the side of the state and the majority group. The emphasis put on protecting Estonian culture in integration policies and the exclusive nature of the national identity prove to transform into a kind of reactive identity among Russian youths, as indicated by the weak sense of belonging to Estonia. In the case of emotional attachment to Russia, we cannot state the direction of the revealed association based on our survey data. The stronger identification with Russia might be a reaction to the lack of sense of belonging to Estonia; however, it could also be a hindrance for the formation of a stronger connection to Estonia.

Both in literature and policy discourse, identificational integration is assumed to lead to the creation of a shared national identity, which requires certain commonalities, such as a shared language and core cultural values. Some consider it to happen at the expense of declining ethnic identities and changing affiliation from country of origin to the host country. Others see it as irrespective of personal identifications with other different groups in society, including the ethnic origin group, and despite retained allegiances and connection to the country of origin. The results of the analysis presented in this chapter tend to support the 
second approach, as the strength of identification with one's ethnic group turned out not to decrease the chances of forming a strong sense of belonging to Estonia. This result indicates that feelings of belonging to both one's ethnic group and to the host society are not mutually exclusive.

However, as yet it is not possible to conclude whether the stronger diasporic identity, which goes together with a weaker sense of belonging to Estonia, is part of a reactive identity, expressing the stronger border drawn between 'us' and 'them'. More thorough qualitative studies in the future could provide an answer. Another question to be addressed by future studies is whether the combination of feelings of neither belonging to the host country and its society, nor to one's ethnic group or country of origin really means that there is a feeling of belonging nowhere, or whether there are other possible groups which serve as substitute sources for feelings of belonging.

\section{Notes}

I For composing the index all the statements were recoded in a way that the smallest value indicates the weakest identification and scale for three items (d, $f$ and $g$ ) were reversed. Cronbach's Alpha $=.830$.

2 The initial sum index was collapsed into four categories as follows: 7-I9 $=\mathrm{I}$ (very weak); $20-25=2$ (weak) 26-3I $=3$ (strong); $32-35=4$ (very strong).

3 Due to the small size of the group with citizenship from countries other than Russia (2.6 per cent), they will be excluded from further analysis.

4 For computing an index the initially measured scales were recoded into three categories and scales of two first statements were reversed. Reliability statistics (Cronbach's Alpha) for the four items is .682. Summing the values of these four variables gives a new variable with values ranging from 4 to I2. For further analysis these will be collapsed into four categories as follows: I) 'Not at all' (those who got the lowest score of 4 and do not perceive any threat on cultural identity); 2) Rather not (scores 5-6); 3) Rather yes (scores 7-9); and 4) Yes (those who got scores I0-I2 and perceive threat on cultural identity according at least to three statements).

5 For composing the index, all the statements were recoded so that the smallest value indicates the weakest identification and scale of one item ('I often wish to conceal the fact that I am a Russian') was reversed. Cronbach's Alpha $=.673$. The initial sum index with values from 5 to 25 was collapsed into four categories indicating the strength of ethnic identity to be either very weak, weak, strong or very strong.

\section{References}

Alba, R. (1990), Ethnic identity: The transformation of white America. New Haven: Yale University Press.

Arredondo, P.M. (1984), 'Identity themes for immigrant young adults', Adolescence I9 (76): $977-993$. 
Baumeister, R.F. \& M.R. Leary (I995), 'The need to belong: Desire for interpersonal attachments as a fundamental human motivation', Psychological Bulletin II7 (3): 497529.

Benveniste, E. (2003), 'Subjectivity in language', in P. de Guy, J. Evans \& P. Redman (eds.), Identity: A reader, 39-43. London: Sage Publications.

Berry, J.W., J.S. Phinney, D.L. Sam \& P. Vedder (2006), 'Immigrant youth: Acculturation, identity, and adaptation', Applied Psychology: An International Review 55 (3): 303-332.

Bloemraad, I., A. Korteweg \& G. Yurdakul (2008), 'Citizenship and immigration: Multiculturalism, assimilation, and challenges to the nation-state', Annual Review of Sociology 34: I53-I79.

Bosswick, W. \& F. Heckmann (2006), 'Integration of migrants: Contribution of local and regional authorities'. Dublin: European Foundation of the Improvement of Living and Working Conditions.

Buijs, F.J. \& J. Rath (2006), 'Muslims in Europe: The state of research'. IMISCOE Working Papers. www.imiscoe.org/publications/workingpapers/documents/ MuslimsinEurope-Thestateofresearch.pdf. Accessed 4 April 2009.

Castles, S. (2002), 'Migration and community formation under conditions of globalization', The International Migration Review 36 (4): II43-II68.

Chow, H.P. (2007), 'Sense of belonging and life satisfaction among Hong Kong adolescent immigrants in Canada', Journal of Ethnic and Migration Studies 33 (3): 5II-52O.

EIS 2008, 'Estonian integration strategy 2008-2013'. www.rahvastikuminister.ee/public/ Loimumiskava_2008_20I3_ENG.pdf. Accessed 23 March 2009.

Esser, H. (2004), 'Does the 'new' immigration require a 'new' theory of intergenerational integration?', International Migration Review 38 (3): II26-II59.

Foner, N. \& R. Alba (2008), 'Immigrant religion in the US and Western Europe: Bridge or barrier to inclusion?', International Migration Review 42 (2): 360-392.

Gans, H.J. (I979), 'Symbolic ethnicity: The future of ethnic groups and cultures in America', Ethnic and Racial Studies 2 (I): I-2O.

Groenewold, G. (2008), 'Identities and intercultural relations', in M. Crul \& L. Heering (eds.), The position of the Turkish and Moroccan second generation in Amsterdam and Rotterdam, I05-I28. IMISCOE Research Series. Amsterdam: Amsterdam University Press.

Guarnizo, L.E., A. Portes \& W. Haller (2003), 'Assimilation and transnationalism: Determinants of transnational political action among contemporary migrants', The American Journal of Sociology IO8 (6): I2II-I248.

Gustafson, P. (2005), 'International migration and national belonging in the Swedish debate on dual citizenship', Acta Sociologica 48 (I): 5-19.

Haller, W. \& P. Landolt (2005), 'The transnational dimensions of identity formation: Adult children of immigrants in Miami', Ethnic and Racial Studies 28 (6): II82-I2I4.

Hallik, K. (2006), 'Kodakondsus ja poliitiline kaasatus (Citizenship and political incorporation)', in Integratsiooni Monitooring 2005 (Integration Monitoring 2005), 60-78. Tallinn: IISS. www.meis.ee/pictures/terve_aruanne.pdf. Accessed 7 May 2009.

Heckmann, F. \& D. Schnapper (2003), 'Introduction', in F. Heckman \& D. Schnapper (eds.), The integration of immigrants in European societies: National differences and trends of convergence, 9-I4. Stuttgart: Lucius and Lucius.

Heckmann, F. (2003), 'From ethnic nation to universalistic immigrant integration: Germany', in F. Heckmann \& D. Schnapper (eds.), The integration of immigrants in European societies: National differences and trends of convergence, 45-78. Stuttgart: Lucius \& Lucius.

Huddy \& N. Khatib (2007), 'American patriotism, national identity, and political involvement', American Journal of Political Science 5I (I): 63-77.

Jenkins, R. (2004), Social identity. London and New York: Routledge. 
Kasinitz, P., J. Mollenkopf \& M.C. Waters (2002), 'Becoming American/becoming New Yorkers: Immigrants incorporation in a majority-minority city', International Migration Review 36 (4): 1020-1036.

Kivisto, P. (2004) 'Inclusion: Parsons and beyond', Acta Sociologica 47 (3): 29I-297.

Kolstø, P. (1995), Russians in the former Soviet republics. London: Hurst and Company.

Korts, K. \& T. Vihalemm (2008), 'Rahvustevahelised suhted, kontaktid ja meie-tunne (Interethnic relations, contacts and us-feeling)', in Integratsiooni Monitooring 2008. Aruanne (Integration of Estonian Society, Monitoring 2008. Report). Tallinn: www.rahvastikuminister.ee/index.php?id=I205I. Accessed I8 February 2009 .

Korts, K. (2009), 'Inter-ethnic attitudes and contacts between ethnic groups in Estonia', Journal of Baltic Studies 40 (I): I2I-I37.

Kurthen, H. (1995), 'Germany at the crossroads: National identity and the challenges of immigration', International Migration Review 29 (4): 914-938.

Kymlicka, W. (1995), Multicultural citizenship: A liberal theory of minority rights. New York: Oxford University Press.

Laitin, D. (1998), Identity in formation: The Russian-speaking population in the near abroad. Ithaca: Cornell University Press.

Lauristin, M. (2008), 'Kodanikud ja mittekodanikud: Venekeelse elanikkonna erinevad kategooriad ja lõimumistendentsid (Citizens and non-citizens: Different categories and integration patterns among Russian-speaking population)', in Integratsiooni Monitooring 2008. Aruanne (Integration of Estonian Society, Monitoring 2008. Report). Tallinn: www.rahvastikuminister.ee/index.php?id=I205I. Accessed I8 February 2009 .

Levitt, P. \& N.B. Jaworsky, (2007), 'Transnational migration studies: Past developments and future trends', Annual Review of Sociology 33: 129-156.

Lotman J. (200I), Kultuur ja plahvatus. Tallinn: Varrak.

Lotman, J. (1999), Semiosfäärist. Tallinn: Vagabund.

Lucassen, L. (2005), The immigrant threat: The integration of old and new migrants in Western Europe since i850. Urbana and Chicago: University of Illinois Press.

Nimmerfeldt, G. (2006), 'Identity and social-psychological adaptation strategies: Theoretical framework for and operationalisation of reactive identity approach. Qualitative analysis of identity formation processes of Russians born in Estonia'. MA dissertation. University of Tallinn.

Nimmerfeldt, G. (2008a), 'Collective identities of Russian and Estonian youth', in 'Integration of second-generation Russians in Estonia': Country report on TIES survey in Estonia, I07-I32. TLÜ RASI, available at www.tiesproject.eu.

Nimmerfeldt, G. (2008b), 'Kodakondsus' (Citizenship), in Integratsiooni Monitooring 2008. Aruanne (Integration of Estonian Society, Monitoring 2008. Report). Tallinn: www. rahvastikuminister.ee/?id=I205I. Accessed I8 February 2009.

Nimmerfeldt, G. (2009), 'Identificational integration of second-generation Russians in Estonia', Studies of Transition States and Societies I (I): 25-35.

Parekh, B. (2000), Rethinking multiculturalism: Cultural diversity and political theory. London: Macmillan.

Pettai, V. \& K. Hallik (2002), 'Understanding processes of ethnic control: Segmentation, dependency and co-optation in post-communist Estonia', Nations and Nationalism 8 (4): 505-529.

Portes, A. \& M. Zhou (I993), 'The new second generation: Segmented assimilation and its variants', Annals of the American Academy of Political and Social Science 530: 74-96.

Portes, A. \& R.G. Rumbaut (I996), Immigrant America: A portrait. 2nd ed. Berkeley: University of California Press.

Portes, A. \& R.G. Rumbaut (200I), Legacies: The story of the immigrant second generation. Berkeley: University of California Press. 
Proos, I. (2006), 'Eestivenelaste keeleoskus ja suhtumine 2007. aasta gümnaasiumireformi (Estonian Russians' language proficiency and attitudes towards the school reform of year 2007)', in Integratsiooni Monitooring 2005 (Integration Monitoring 2005), 20-32. Tallinn: IISS. www.meis.ee/pictures/terve_aruanne.pdf. Accessed 20 May 2009.

Rumbaut. R.G. (I994), 'The crucible within: Ethnic identity, self-esteem, and segmented assimilation among children of immigrants', International Migration Review 28 (4): 748-794.

Saar, E. (2008), 'Haridus' (Education), in Integratsiooni Monitoring 2008. Aruanne (Integration of Estonian Society, Monitoring 2008. Report). Tallinn: www.rahvastikuminister.ee/?id=I2051. Accessed i9 April 2009.

Schnapper, D., P. Krief \& E. Peignard (2003), 'French immigration and integration policy: A complex combination', in F. Heckman \& D. Schnapper (eds.), The integration of immigrants in European societies: National differences and trends of convergence, I544. Stuttgart: Lucius and Lucius.

Schneider, J. \& S. Stojčić (2008), 'Second generation identities: First comparative results from TIES', presentation held at TIES Academic Conference, Amsterdam, II-I3 December 2008, available at www.tiesproject.eu.

Schulze, J. (2008), 'Social relations', in 'Integration of second generation Russians in Estonia: Country report on TIES survey in Estonia', I07-I32. TLÜ RASI, available at www.tiesproject.eu.

Tajfel, H. \& J. Turner (I979), 'An integrative theory of intergroup conflict', in S. Worchel \& W.G. Austin (eds.), The social psychology of intergroup relations, 33-48. Pacific Grove: CA/Brooks/Cole.

Tajfel, H. (I98I), Human groups and social categories: Studies in social psychology. London: Cambridge University Press.

Taylor, C. (I992), Multiculturalism and 'the politics of recognition'. Princeton: Princeton University Press.

Thomson, M. \& M. Crul (2007), 'The second generation in Europe and the United States: How is the transatlantic debate relevant for further research on the European second generation?', Journal of Ethnic and Migration Studies 33 (7): 1025-I04I.

Uberoi, V. (2007), 'Social unity in Britain', Journal of Ethnic and Migration Studies 33 (I): I4I-I57.

Valk, A. \& K. Karu (I997), 'Millel põhinevad eestlaste hoiakud teiste rahvuste suhtes? (What is the basis for ethnic attitudes of Estonians?)', in P. Järve (ed.), Vene noored Eestis: Sotsioloogiline mosaiik (Russian youth in Estonia: Sociological mosaic), I7I-I80. Tallinn: Project VERA and Avita.

Waters, M. (I990), Ethnic options: Choosing identities in America. Berkeley. University of California Press.

Vetik, R. \& G. Nimmerfeldt (2008a), 'Riigiidentiteet: Eestlaste ja venelaste võrdlus (State identity: Comparison of Estonians and Russians)'. Uurimisraport (Research report). Tallinn: IISS/the State Chancellery.

Vetik, R. \& G. Nimmerfeldt (2008b), 'Lihtsustatud korras kodakondsuse taotlemisest lastele (Acquiring the Estonian citizenship summarily for minors)'. Uurimisprojekti 'Kodakondsuseta laste vanemad' raport (Report on research project 'Parents of children with undetermined citizenship status'). Tallinn: IISS/The State Chancellery.

Vetik, R. (2006), 'Suur ühiskond (Great society)', in Projekti 'Demokraatia ja rahvuslikud huvid. Eesti ühiskond 2005' raport (Project report 'Democracy and national interests. Estonian society in 2005'), I7-35. Tallinn: Avatud Eesti Fond.

Vetik, R. 2008, 'Etniline domineerimine Eestis (Ethnic domination in Estonia)', in M. Tamm \& P. Petersoo (eds), Monumentaalne konflikt: Mälu, poliitika ja identiteet 
tänapäeva Eestis. (Monumental conflict: Memory, politics and identity in contemporary Estonia), II2-I26. Tallinn: Varrak.

Vetik, R., G. Nimmerfeldt \& M. Taru (2006), 'Reactive identity versus the EU integration', Journal of Common Market Studies 44 (5): I077-IIoO.

Vihalemm, T. \& A. Masso (2003), 'Identity dynamics of Russian speakers of Estonia in the transition period', Journal of Baltic Studies 34 (I): 92-II6.

Vihalemm, T. \& V. Kalmus (2009), 'Cultural differentiations of the Russian minority', Journal of Baltic Studies 40 (I): 95-II9. 
Appendix 10.1 Sense of belonging to Estonia strongly or very strongly, odd ratios $\left(\operatorname{Exp}\left(b_{i}\right)\right)$, logistic regression models

\begin{tabular}{|c|c|c|}
\hline & Model 1 & Model 2 \\
\hline \multicolumn{3}{|c|}{ 1. Citizenship status (reference group: Estonian citizenship by birth) } \\
\hline No citizenship & .642 & .662 \\
\hline Russian citizenship & 1.040 & 1.757 \\
\hline Estonian citizenship by naturalisation & 1.071 & 1.001 \\
\hline \multicolumn{3}{|l|}{ 2. Discrimination } \\
\hline \multicolumn{3}{|c|}{$\begin{array}{l}\text { Experienced hostility/unfair treatment (reference group: Having } \\
\text { experienced) }\end{array}$} \\
\hline Never experienced & .741 & .595 \\
\hline \multicolumn{3}{|c|}{ Being offended (reference group: Having experienced) } \\
\hline Never experienced & 1.549 & 1.747 \\
\hline \multicolumn{3}{|c|}{ Perceived discrimination against Russians (reference group: Frequently) } \\
\hline Never & 1.815 & 2.511 \\
\hline Rarely & 1.848 & 2.446 \\
\hline Occasionally & 1.472 & 1.635 \\
\hline \multicolumn{3}{|c|}{ 3. Perceived threat on cultural identity (reference group: Yes) } \\
\hline Not at all & $8.545 * * *$ & $8.829 * * * *$ \\
\hline Rather not & $3.163 * *$ & $2.961 *$ \\
\hline Rather yes & 1.405 & 1.469 \\
\hline \multicolumn{3}{|l|}{ 4. Interethnic relations } \\
\hline \multicolumn{3}{|c|}{ Ethnicity of current friends (reference group: Several) } \\
\hline None & .635 & .719 \\
\hline Few & 1.019 & 1.227 \\
\hline \multicolumn{3}{|c|}{ Ethnicity of best three friends (reference group: One or more } \\
\hline \multicolumn{3}{|l|}{ Estonian) } \\
\hline None & .727 & .688 \\
\hline \multicolumn{3}{|l|}{ 5. Transnational ties and attachment to Russia } \\
\hline \multicolumn{3}{|c|}{ Visiting Russia past five years (reference group: Three or more times) } \\
\hline Never & .726 & 738 \\
\hline Once & .646 & .711 \\
\hline Twice & .833 & 1.046 \\
\hline \multicolumn{3}{|c|}{ Time spent in Russia (reference group: Month or more) } \\
\hline Less than one month & 1.483 & 1.945 \\
\hline \multicolumn{3}{|c|}{ Watching TV stations (reference group: Russian language only) } \\
\hline Russian and Estonian languages & 1.675 & 1.115 \\
\hline Mostly Russian, a little Estonian & 1.357 & 1.370 \\
\hline \multicolumn{3}{|c|}{ Intention to live in Russia (reference group: Maybe or certainly yes) } \\
\hline Certainly not & $2.168 * *$ & $2.322 *$ \\
\hline \multicolumn{3}{|c|}{ Considering Russia the homeland (reference group: Yes) } \\
\hline No & $3.065 \%$ & $3.328 *$ \\
\hline Don't know & 1.155 & 1.313 \\
\hline \multicolumn{3}{|c|}{$\begin{array}{l}\text { Feeling connected to Russia (reference group: Strongly or very } \\
\text { strongly) }\end{array}$} \\
\hline Not at all or very weakly & .509 & .456 \\
\hline Weakly & .590 & .567 \\
\hline Moderately & .788 & .664 \\
\hline
\end{tabular}


Appendix 10.1 continued

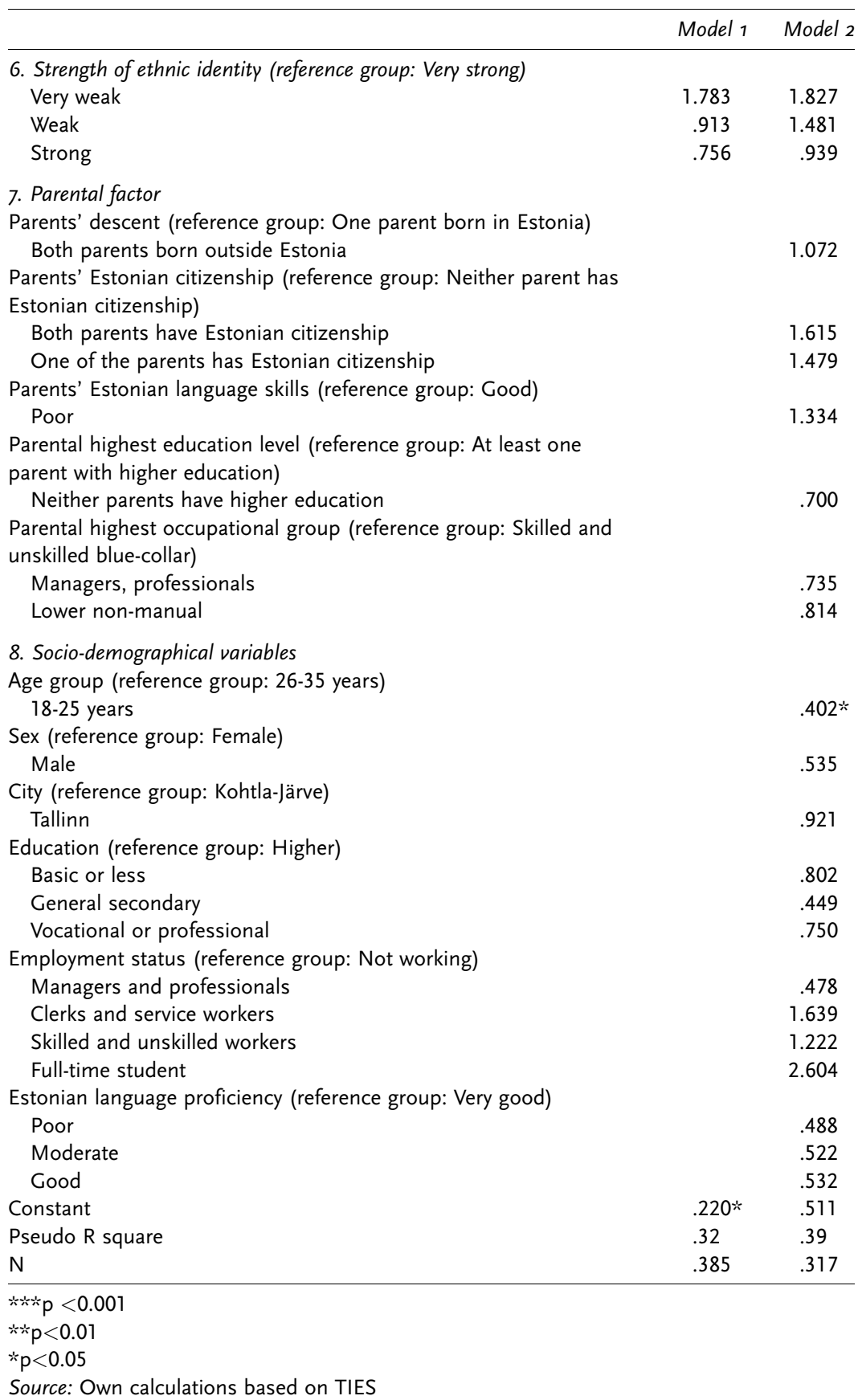




\title{
11 Conclusions
}

\author{
Raivo Vetik and Jelena Helemäe
}

The analysis in this volume indicates that the main issues compounding the Russian second generation's integration are as follows: their segregation from the Estonian language society, which has its historical background in the policies and social processes of the former Soviet Union; disparity compared to their native peers, both in terms of social and economic opportunities, which is mostly the result of the new institutions established by the Estonian state after regaining independence; and reactivity of young Russians towards these policies, which has a potential to escalate, in certain conditions, into a large-scale conflict.

Soviet policy in Estonia could be characterised as a socialist type of modernisation of Estonian society. The ethnic segmentation, which emerged in that context, was in many ways the by-product of the bureaucratic command economy. Ethnic segmentation has emerged not only in the economic sphere, but also in education (two parallel school systems), the regional sphere (Ida-Virumaa and Tallinn versus the rest of Estonia), the neighbourhood (apartment houses were built either by pan-Soviet enterprises or by local authorities) and social networks (which were enterprise-centred). Besides ethnic segmentation, the Soviet period is also characterised by the Russians' privileged status in many spheres of social and political life and the Estonians' high level of threat perception regarding the rapidly growing share of migrant population and Russification policies, accompanying the demographic changes. These are important factors also in the context of the current integration issue in Estonia, mainly as the reasons behind the Estonians' comparatively high ethnocentric attitudes, which in many ways can be regarded as a reaction to the fear and injustice experienced during the Soviet period.

After the restoration of independence, the Estonian political elite chose a nation-state model based on the legal continuity principle, in order to overcome the Soviet legacy and build up a new type of society and state, as well as in the context of internal power struggle. This principle, as such, is merely a legal notion, but the social and political consequences of its implementation carry very strong ethnic connotations. Since this legal model became the basis of many new social and political institutions, that strongly influence the cohesion of the society, it 
gave rise to an emergence of ethnic based status hierarchies (for example, by large-scale lack of Estonian citizenship among Russians). The issue of national integration has therefore been strongly politicised during the recent decades. Many Russians perceive the institutions that were established in the framework of the new nation-state model as discriminating towards their group. At the same time, their protest against the model, as well as their political mobilisation as a whole, has remained rather modest. Here we can refer to a major difference between Estonia and most Western European societies facing the integration challenge - the native majority group has been much more mobilised and internally consolidated during the last decades, compared to the migrant group, which has remained politically fragmented during the whole post-Soviet period (Pettai \& Hallik 2002).

The politicisation of ethnic relations and the consequent threat perceptions place different collective memories and identities at the centre of the integration issue in Estonia. One dramatic finding of this volume reveals that almost half of Russian youths consider their attachment to Estonia to be weak or very weak, as a result of a number of negative social and political processes discussed in this volume. A discursive mechanism in public opinion that contributes to such dispositions is the fact that the terms 'nationality' and 'ethnic group' are not differentiated for Estonians and Russians, which means that the category 'Estonian nation' is ethnically overloaded for both of them. For example, our analysis reveals that only 6 per cent of second-generation Russians feel that they strongly belong and I per cent that they very strongly belong to the category 'Estonians'. A similar result for the whole population in the Integration Monitoring 2008 reveals that among the Russian respondents, only i4 per cent feel they belong to the category 'Estonians'. This indicates that in Estonia this category is perceived, primarily, in ethnic terms. However, this does not mean that the strength of the ethnic identity of the Russian second generation is a good predictor for the level of their attachment to Estonia. Our analysis reveals that variation in the strength of ethnic pride among Russians is not related to their different levels of sense of belonging to Estonia, which indicates that feelings of belonging to the Russian ethnic group and Estonia are not mutually exclusive.

Analysis carried out in this volume reveals that the main factor that influences the Russians' feeling of belonging to Estonia is the extent of their sense of threat in respect of preserving their cultural uniqueness. This indicates that perceiving the Estonian state's ethnopolicy in terms of assimilation significantly weakens their sense of belonging to Estonia. The effect of the perceived threat on cultural identity is explained in the volume using the concept of reactive identity. This concept presumes that many Russians react to perceived assimilative pressures by creating 
particularly strong boundaries between themselves and the Estonian state. In extreme cases, such a reaction results in opposing whatever the Estonian state is undertaking, including those policies aimed at improving the position of minorities in society (Vetik 2008a).

The importance of the phenomenon of reactive identity in shaping the sense of belonging of Russian youth is shown, among other things, by the fact that all other tested factors, which, according to theory could have also been of importance, were in fact not. For example, having Estonian friends does not change the likelihood of feeling a belonging to Estonia. Neither do the different measures of transnationalism - the frequency of visits or time spent in Russia - have an impact on their feeling of belonging in Estonia. In addition, the respondents' parental background is not important either in this regard: for young Russians with only one parent born outside Estonia, the odds of feeling a belonging in Estonia are not increased compared to those with two parents born outside Estonia; the odds are also not increased by the parents' higher social status and their country-specific human capital. However, this volume reveals that the respondent's age does have an important impact on the sense of belonging to Estonia among young Russians. Those in the age group I8-25 years in the sample feel less connected to Estonia, compared to the group of 26-35 year olds. This is probably because young people are, as a rule, more emotional, which channels into their higher reactivity.

The key role of the issues of identificational integration in this study does not mean that the problems related to second-generation Russians' structural integration are secondary. Estonia's important particularity, compared to most other integration states, is the fact that the creation of a new nation-state model occurred simultaneously with the transition to a market economy and the establishment of the respective institutions. The model of market economy chosen in Estonia in the I990s is one of the most liberal among other transition states. One can argue that a certain parallelism exists between the neoliberal economic model and a nation-state model with an ethnic connotation (Vetik 2007). These models are interrelated in such a way that both have created premises for the emergence of strongly stratified different status groups in the society. As a result, both have weakened the cohesiveness of the society and presume group-targeted integration policies to extenuate the emerged social consequences.

Thus, the implementation of neoliberal, as well as ethnic nation-state ideology, has created a new kind of opportunity structure in Estonian society, contributing to the emergence of a new type of economic and ethnic inequality. This raises the question, to what extent does the socio-economic stratification converge with the ethnic division lines and to what extent do these division lines amplify the stratification? The 
analyses in this volume confirm that such an overlap in Estonia is remarkable. While in most other immigration countries there are tendencies of convergence between natives and second-generation immigrants regarding structural integration, compared to their parents (Thomson \& Crul 2007), in Estonia the dynamics are reversed. This indicates that young Russians have had limited opportunities to achieve the same parity of socio-economic status as their parents had in the Soviet period, compared to native Estonians. However, public debate in Estonia on these matters is characterised by a legitimisation of the occurred socioeconomic disparity through construing a black-and-white world view, where those disagreeing with neoliberalism are labelled coveters of 'Soviet times'. In that discourse, the convergence of ethnic characteristic and economic disparity is not viewed as a problem, as it is not regarded to be an impact of nationalising policies, but simply as the functioning of the market economy (Vetik 2007).

The analysis of the labour market integration in this volume highlights the existence of clear structural inequalities between second-generation Russians and their Estonian counterparts. Russians have lower chances of obtaining a high occupational position or earning a high income. It is argued in this volume that neither the widely used human capital theory, nor its extension in the form of the country-specific human capital thesis, offer an adequate explanation for the ethnic inequalities in Estonia. Human capital does matter but only to a certain extent. The same applies to the explanation along the concept of social reproduction: parental educational resources appeared to be of particular importance for the youngsters' labour market success but still not powerful enough to bridge the ethnic gap.

This would not be a surprising result if the Estonian case were not substantially different from the typical ones in Western Europe, in terms of underlying assumptions. As chapter four of this volume emphasises, in Western literature the lower labour market success of second-generation immigrants is often explained by poor parental resources. This is not necessarily the case in Estonia, as the immigrant population first generation in Estonia is highly different from the average non-European, poorly educated first-generation immigrants in Western Europe. The educational level of the first-generation Russians was even somewhat higher compared to Estonians; the share of managers and professionals among them was almost the same as among Estonians. Thus, an important feature of the current state of affairs with the structural integration of second-generation Russians is revealed in the education chapter: as ethnic disparities between them and their Estonian counterparts are now deeper compared with their parents' generation during the Soviet period, such new inequalities can be regarded as outcomes of developments of the post-Soviet period. 
This volume suggests that it is the new institutional setting that has had a negative impact on the second generation's educational attainment, by decreasing their possibilities to obtain higher education. Instead of a gradual change in the education system, after I99I the government chose to launch a quick transition towards teaching in higher education institutions only in the Estonian language. At the same time, the quality of Estonian language instruction at Russian secondary schools was rather poor. Although there are no legal restrictions on access to any levels of education for immigrants in Estonia, higher education opportunities for people not proficient in Estonian are limited.

It may further be suggested that the poor quality of Estonian language instruction at secondary schools, coupled with the strict (and frequently changed) language requirements stated by the Language Law, created an opportunity structure for second-generation Russians in which their fluency in Estonian (a kind of country-specific human capital) largely depends on parental (cultural, social and financial) resources. At the same time, as this volume reveals, investment in such country-specific human capital is crucial for second-generation Russians to achieve higher occupational positions and belong to the higher wage-earners group in the Estonian labour market. First, very good Estonian language writing skills significantly raise the probability of labour market success, both in terms of income and occupational position. In addition, Russians who have studied in Estonian language schools also have an advantage compared to Russians who have never studied in Estonian language, and their chances of attaining high occupational positions are also higher.

The following question can be posed: if the intergenerational transmission of resources is of such crucial importance for second-generation Russians, why have the results presented in this volume not revealed the decisive impact of parental resources on the Russians' success? Instead, it has been revealed that the way social reproduction of inequalities presents itself in Estonia varies by the specific area of integration. When it comes to education, it is important for second-generation Russians to have highly educated parents: they need to have parents with higher education and high occupational position to improve their chances of attaining higher education. The educational success of young Estonians also depends on the parental occupational group, but the impact is weaker. As to the achievement of a high occupational position, a direct effect of parental resources was found in this volume only for Estonians - higher parental education provides labour market advantages for the Estonian youth despite their own educational level, while there is no such effect for Russians. Thus, second-generation Russians gain less from an advantageous parental background than natives. One possible answer to the above question is that we might not 
be aware of the meaning of the importance of parental resources for children's success (what matters and what does not matter in the case of the so-called 'old' education - whether it is just human capital or a social one).

The next question is: what are the concrete mechanisms that shape the revealed ethnic inequalities? First, what might influence the educational choices of young Russians? Following Esser's line of argumentation, it is suggested in this volume that differential returns on educational investments might reduce the perception of education usefulness and success expectations of the following generation. This situation is a result of both generic and ethnic stratification processes, influenced by the Soviet past and structured by both the generic and targeted integration policies of the Estonian state. However, how it is linked to the institutional level needs to be studied in future.

Thus, considering the institutions, established by the Estonian state, that impact the society's integration, an instrumental dimension can be distinguished on one hand and an ideological one on the other. If the goal of the education system, in the instrumental sense, is to be the equaliser of opportunities for all members of society, then the specific form of education reform chosen in the context of the ethnically connoted Estonian nation-state model (i.e. not a gradual bottom-up but a fast top-down reform regarding the language of instruction) has, as a whole, created an ethnic disparity as well. Therefore, policies implemented in the framework of the Estonian nation-state model place issues of education and the labour market in a somewhat different context compared to states which follow a more liberal model. This is also the reason why standard theories, which explain ethnic disparity in the labour market and the education system elsewhere in Europe, may not apply in the Estonian case.

The current volume indicates that the social integration of Estonian and Russian youths (the frequency and nature of the contact) is weak. This confirms the results of earlier studies about Estonian society as a whole, which demonstrate that especially the extra-vocational interaction networks are extremely centred around one's own ethnicity (Korts \& Vihalemm 2008). In the context of an ethnically connoted nation-state, Estonians and Russians do not consider themselves as subjects with equal status. Therefore, it can be presumed that the impact of the frequency and nature of their contacts on the integration processes is different, compared with the contacts in liberal society. Our analysis reveals that having friends who are members of the out-group increases the odds of viewing interethnic relations favourably among Russians, but not among Estonians. However, ethnically more heterogeneous friendship networks do not help second-generation Russians attain a higher occupational position. Furthermore, living in ethnically unmixed 
neighbourhoods appears to have the opposite effects for ethnic Russians and ethnic Estonians. For Russians, living in ethnically unmixed neighbourhoods increased the odds of viewing interethnic relations negatively. For Estonians the same situation decreased the odds of holding negative views. Therefore, if, in the context of the liberal model, contacts between groups with equal status contribute, as a rule, to the improvement of other integration indicators as well, this might not be the case in the context of the ethnic nation-state model (Stepick, Grenier, Castro \& Dunn 2003). Thus, in Estonian circumstances, contacts are mainly a personal matter. As close as contacts might become, they are unable to circumvent the ethnic hierarchy reproduced in the public sphere.

It can be presumed that status hierarchy is also one of the factors behind the low level of intermarriage and high level of neighbourhood segregation between Estonians and Russians. The main patterns of current ethnic segregation on the residential level in Estonia can be traced back to the migration and housing policies of the Soviet period, which facilitated the formation of these specific housing relations, allocation and distribution practices, the construction and aesthetic qualities of the residential structures, the social composition of residents in neighbourhoods and the spatial separation of ethnicities. Current housing types in Estonia reveal a certain persistency of cultural models that characterise different ethnic groups and link the first and second generations by repeated housing behaviour patterns. More Russians continue living in flats, often in circumstances of higher density, and more Estonians continue living in family houses. However, differently from patterns known in Western cities, and especially the United States, Estonian ethnic minorities present mixed groups of residents without high concentrations of low capacities in the neighbourhood.

One feature of ethnic segmentation in Estonian society is the low level of intermarriage between Estonians and Russians. The reasons behind that are related to the other aspects of ethnic segmentation, as well as to differences in the understanding of gender roles between Estonians and Russians. Our volume reveals that while in the labour market and public sphere, in general, we can speak of a certain equalisation of attitudes among young people with a different ethnic background, the trend of equalisation has yet to touch the attitudes in the private sphere. The findings in this volume show a higher support for traditional gender roles in the family among Russians. The findings also demonstrate that in spite of relatively small ethnic differences in the actual division of household tasks and responsibilities, there are significant differences in the attitudes on how these tasks should be divided in the ideal case. The traditional attitudes, especially concerning 
support towards the father's role as a breadwinner, are more noticeable among Russians, and particularly among Russian men.

The analyses of the current volume confirm that, in the context of the ethnically connoted nation-state, the integrative potential of several aspects of the second-generation Russians' adaptation process become weaker. Therefore, in assessing the success of their integration, it is necessary to differentiate facets related to utility and attachment. Our volume reveals that, young Russians, for example, learn Estonian for pragmatic reasons, but this will not promote their identificational integration (see also Vihalemm 2008). Hence, on the one hand, Estonian is learned because the skill of speaking Estonian is considered useful in the labour market. On the other hand, in the framework of the ethnically connoted nation-state, state policies targeted to improve Estonian skills are perceived as coercion from above. This provokes a negative counter reaction, transforming Estonian language studies into an activity of bare instrumental significance.

The lack of cohesion between the instrumental and identificational aspects of the integration process of second-generation Russians emerges, in addition to language skills, in several other spheres. For example, our volume has revealed that citizenship status, or the way Estonian citizenship is acquired by young Russians, plays no significant role in their sense of belonging to Estonia. Thus, Estonian citizenship status is more of a pragmatic choice and a type of social investment, than the measure of a person's civic identity (see also Lauristin 2008). It can be assumed that the implementation of the principle of legal continuity in citizenship policy at the beginning of the I990s, on which the Estonian nation-state model was based, is interpreted by many Russians as the state signalling 'you are strangers and do not belong here'. As a result, their emotional attachment to Estonia only relates to personal matters like family and home but not to public sphere factors like citizenship status. Previous qualitative research strongly confirms such a result (Vetik \& Nimmerfeldt 2008).

In conclusion, it can be implied that the Russians' second-generation ethnic segmentation and status inequality described in this volume create a fertile ground for ethnic conflict. As Russia attempts to restore its impact on the former Soviet room by intervening in matters of neighbouring states and Estonian political parties are utilising this matter in their power struggle for gaining votes, there is a real prospect that such processes could escalate into a large-scale ethnic confrontation, something well illustrated by the Bronze Soldier crisis of April 2007. In the framework of the ethnically connoted nation state-model, the practical steps of integration policy have been reduced, so far, mainly to the instrumental aspects of integration. This is expressed, for example, in the Russians' large-scale lack of citizenship and in the fact that the main 
activities in that sphere are information campaigns about the advantage of possessing Estonian citizenship, as well as changing the event of receiving the citizenship certificate into a festive occasion (Vetik 2008b). Although one can hope for certain positive results from these kinds of activities, such measures fail to touch the core of the citizenship issue in Estonia. Thus, real progress in handling the issues of ethnic segmentation, disparity and reactivity in Estonian society described in this volume presumes taking a broader approach and implementing more substantial measures and is not reduced to the targeted integration policies only. One can suppose that the crucial factor with regard to the direction of further development of the integration issue in Estonia has to do with the capability of the political system to create a framework for a more equitable interethnic relationship. This would decrease alienation of young Russians from the Estonian state and promote cooperative and mutually trustful dispositions both among minority and among majority populations.

\section{References}

Korts, K. \& T. Vihalemm (2008), 'Rahvustevahelised suhted, kontaktid ja meie-tunne (Interethnic relations, contacts and us-feeling)', in Integratsiooni Monitooring 2008. Aruanne (Integration of Estonian Society, Monitoring 2008. Report), I07-II6. Tallinn: www.rahvastikuminister.ee/index.php?id=I2051. Accessed 6 April 2009.

Lauristin, M. (2008), 'Kodanikud ja mittekodanikud: Venekeelse elanikkonna erinevad kategooriad ja lõimumistendentsid (Citizens and non-citizens: Different categories and integration patterns among Russian-speaking population)', in Integratsiooni Monitooring 2008. Aruanne (Integration of Estonian Society, Monitoring 2008. Report), I42-I63. Tallinn: www.rahvastikuminister.ee/index.php?id=I205I. Accessed 8 April 2009.

Pettai, V. \& K. Hallik (2002). 'Understanding process of ethnic "control”: Segmentation, dependency and co-optation in post-communist Estonia', Nations and Nationalism 8 (4): 505-529.

Stepick, A., G. Grenier, M. Castro \& M. Dunn (2003), This land is our land: Immigrants and power in Miami. Berkeley: University of California Press.

Thomson, M. \& M. Crul (2007), 'The second generation in Europe and the United States: How is the transatlantic debate relevant for further research on the European second generation', Journal of Ethnic and Migration Studies 33 (7): I025-IO4I.

Vetik, R. (2007), 'Suur ühiskond (Great society)', in R. Vetik (ed.), Kahe vabaduse piiril (On the border of two freedoms). Tallinn: K Print.

Vetik, R. (2008a), 'Riigiidentiteet ja ühiskonna avaliku sfääri sidusus (State identity and the cohesiveness of society's public sphere)', in Integratsiooni Monitooring 2008. Aruanne (Integration of Estonian Society, Monitoring 2008. Report), I64-I79 Tallinn: www.rahvastikuminister.ee/?id=I2051. Accessed 5 April 2009.

Vetik, R. (2008b), 'Vaade mittekodaniku hinge (Exploring the soul of non-citizen)', Delfi. www.delfi.ee/news/paevauudised/arvamus/article.php?id=20250355.

Accessed 4 November 2008. 
Vetik, R. \& G. Nimmerfeldt (2008), 'Riigiidentiteet: Eestlaste ja venelaste võrdlus (State identity: Comparison of Estonians and Russians)'. Uurimisraport (Research report). Tallin: IISS/The State Chancellery.

Vihalemm, T. (2008), 'Keeleoskus ja hoiakud (Language proficiency and attitudes)', in Integratsiooni monitooring 2008. Aruanne (Integration of Estonian Society, Monitoring 2008. Report), 7I-80. Tallinn: www.rahvastikuminister.ee/?id=I205I.Accessed 8 April 2009 . 


\section{Appendix}

\section{The organisational and methodological background of the survey on second-generation Russians in Estonia}

Empirical analyses presented in this volume are based on the Russian Second Generation Survey in Estonia, a sub-project of 'The Integration of the European Second Generation' (TIES). This larger international comparison, initiated by the Institute for Migration and Ethnic Studies (IMES) at the University of Amsterdam, began in 2005. At the beginning of 2006, the Institute of International and Social Studies (IISS) at Tallinn University became an associated member of TIES. The survey design followed, as far as possible, the concepts, definitions, indicators and questionnaire modules of the larger TIES project. From January to December 2006, a team comprising six researchers from different departments of IISS $^{2}$ worked on adapting the TIES survey as an instrument apt for the Estonian situation and the new target group. The questionnaire for Russian youth was translated into Russian during September and October 2006 and a pilot study was conducted in October and November of that year.

IISS also participated in developing the common questionnaire of the TIES group from January to August 2006. In addition, members of the research team participated in conferences coordinated by TIES, benefiting from both the knowledge of the methodological challenges that fellow TIES participants faced in the field as well as solutions that were implemented.

Finance for participation in the development of a common questionnaire, and its adaptation for Russian youth in January to August 2006, was provided by the Chancellery of the Republic of Estonia. The survey implementation in Estonia was financed by a grant from Tallinn University Research Council. As the fieldwork turned out to consume more time and resources than expected, extra funding for finishing the survey was supplied by the City Government of Tallinn and the Chancellery of the Republic of Estonia. Funding for cleaning up and processing the database and the analysis carried out for writing up the country report came from the Estonian Science Foundation Grant No. 
Table 12.1 Description of sample

\begin{tabular}{lccccccc}
\hline & \multicolumn{2}{c}{ Tallinn } & & \multicolumn{2}{c}{ Kohtla-Järve } & & Jõhvi \\
\cline { 2 - 3 } & Estonians & Russians & & Estonians & Russians & & Estonians \\
\hline $\begin{array}{l}\text { Target number } \\
\begin{array}{c}\text { of respondents } \\
\text { Interviewed respondents }\end{array}\end{array}$ & 250 & 250 & & 250 & 250 & NA \\
\hline
\end{tabular}

Source: Own calculation based on TIES

7720 'Integration of Second Generation Russians in Estonia', (grant holder Prof. Raivo Vetik).

The fieldwork began in January 2007 and concluded in March 2008 (altogether almost fourteen months, although it should be noted that the fieldwork was postponed for a couple of months following the Bronze Soldier riots at the end of April 2007). The fieldwork was implemented by the survey bureau OÜ Faktum \& Ariko in close consultation and cooperation with the research team at IISS.

The method used for survey data collection was face-to-face interviews at the respondents' homes. Interviews were held in respondents' mother tongue. Altogether 43 interviewers, both Estonians and Russians, were specially trained on the project's aims and methods so that they could conduct the interviews. In total, I, ০oo interviews (488 with Estonian youth and 512 with Russian youth) were conducted in Tallinn and in two cities in Ida-Virumaa. A third city (Jõhvi) was included because of the difficulties of finding Estonian respondents from the eligible age group in Kohtla-Järve. Jõhvi is very close to Kohtla-Järve and, in fact, in Soviet times it was a part of Kohtla-Järve.

Data entry was undertaken by OÜ Faktum \& Ariko in April 2008 using the QPS data processing programme. The logistic control of data was executed with SPSS. Two databases in SPSS format, one for the Estonian sample and another for the Russian sample, were handed over to IISS on 30 April 2008. These databases were cleaned up, synchronised and merged into one dataset and the conjoint database was translated into English from May to July 2008.

\section{Notes}

I The Appendix originates from the country report on the TIES survey in Estonia that is available at www.tiesproject.eu.

2 Rein Vöörmann, Jelena Helemäe and Ellu Saar from the Department of Social Stratification; Leeni Hansson from the Department of Family Sociology; Raivo Vetik and Gerli Nimmerfeldt from the Department of Ethno-Sociology and Politics. 


\section{List of contributors}

Raivo Vetik, Coordinator of the TIES project in Estonia; Senior Researcher, Institute of International and Social Studies; Professor of Comparative Politics, Institute of Government, Tallinn University, Tallinn, Estonia raivo.vetik@iiss.ee

Jelena Helemäe, Senior Researcher, Institute of International and Social Studies, Tallinn University, Tallinn, Estonia jelena.helemae@iiss.ee

Ellu Saar, Senior Researcher, Institute of International and Social Studies, Tallinn University, Tallinn, Estonia ellu.saar@iiss.ee

Rein Vöörmann, Senior Researcher, Institute of International and Social Studies, Tallinn University, Tallinn, Estonia rein.voormann@iiss.ee

Leeni Hansson, Senior Researcher, Institute of International and Social Studies, Tallinn University, Tallinn, Estonia hansson@iiss.ee

Liis Ojamäe, Researcher, Institute of International and Social Studies, Tallinn University, Tallinn, Estonia liis.ojamae@tlu.ee

Kristina Lindemann, Researcher, Institute of International and Social Studies, Tallinn University, Tallinn, Estonia kristina.lindemann@iiss.ee

Katrin Paadam, Professor and Chair of Business Sociology, Department of Public Economy, Tallinn University of Technology, Tallinn, Estonia katrin.paadam@tseba.ttu.ee 
Gerli Nimmerfeldt, Researcher, Institute of International and Social Studies, Tallinn University, Tallinn, Estonia gerli@iiss.ee

Jennie Schulze, Assistant Professor of Political Science, Duquesne University, Pittsburg, Pennsylvania, United States schulzej@duq.edu

Nastja Sokolova, Project Manager, Narva Museum, Narva, Estonia sokolova@narvamuuseum.ee 
Other IMISCOE titles

\section{IMISCOE Research}

Rinus Penninx, Maria Berger, Karen Kraal, Eds.

The Dynamics of International Migration and Settlement in Europe: A

State of the Art

2006 (ISBN 9789053568668 )

(originally appearing in IMISCOE Joint Studies)

Leo Lucassen, David Feldman, Jochen Oltmer, Eds.

Paths of Integration: Migrants in Western Europe (1880-2004)

2006 (ISBN 9789053568835 )

Rainer Bauböck, Eva Ersbøll, Kees Groenendijk, Harald Waldrauch, Eds. Acquisition and Loss of Nationality: Policies and Trends in 15 European

Countries, Volume 1: Comparative Analyses

2006 (ISBN 9789053569207 )

Rainer Bauböck, Eva Ersbøll, Kees Groenendijk, Harald Waldrauch, Eds. Acquisition and Loss of Nationality: Policies and Trends in 15 European Countries, Volume 2: Country Analyses

2006 (ISBN 978905356 92I 4)

Rainer Bauböck, Bernhard Perchinig, Wiebke Sievers, Eds.

Citizenship Policies in the New Europe

2007 (ISBN 978905356922 I)

Veit Bader

Secularism or Democracy? Associational Governance of Religious Diversity 2007 (ISBN 978905356999 3)

Holger Kolb, Henrik Egbert, Eds.

Migrants and Markets: Perspectives from Economics and the Other

Social Sciences

2008 (ISNB 9789053566848 )

Ralph Grillo, Ed.

The Family in Question: Immigrant and Ethnic Minorities in

Multicultural Europe

2008 (ISBN 978905356869 9) 
Corrado Bonifazi, Marek Okólski, Jeannette Schoorl, Patrick Simon, Eds. International Migration in Europe: New Trends and New Methods of Analysis 2008 (ISBN 978905356894 I)

Maurice Crul, Liesbeth Heering, Eds.

The Position of the Turkish and Moroccan Second Generation in Amsterdam and Rotterdam: The TIES Study in the Netherlands 2008 (ISBN 978908964 06I I)

Marlou Schrover, Joanne van der Leun, Leo Lucassen, Chris Quispel, Eds. Illegal Migration and Gender in a Global and Historical Perspective 2008 (ISBN 978908964047 5)

Gianluca P. Parolin

Citizenship in the Arab World: Kin, Religion and Nation-State 2009 (ISBN 978908964045 I)

Rainer Bauböck, Bernhard Perchinig, Wiebke Sievers, Eds. Citizenship Policies in the New Europe: Expanded and Updated Edition 2009 (ISBN 978908964 I08 3)

Cédric Audebert, Mohamed Kamel Doraï, Eds.

Migration in a Globalised World: New Research Issues and Prospects 20IO (ISBN 978908964 I57I)

Richard Black, Godfried Engbersen, Marek Okólski, Cristina Pantîru, Eds. A Continent Moving West? EU Enlargement and Labour Migration from Central and Eastern Europe 20I0 (ISBN $978908964 \mathrm{I}_{5} 64$ )

Charles Westin, José Bastos, Janine Dahinden, Pedro Góis, Eds. Identity Processes and Dynamics in Multi-Ethnic Europe 2010 (ISBN 9789089640468 )

Rainer Bauböck, Thomas Faist, Eds.

Diaspora and Transnationalism: Concepts, Theories and Methods 20IO (ISBN 978908964238 7)

Liza Mügge

Beyond Dutch Borders: Transnational Politics among Colonial Migrants, Guest Workers and the Second Generation 20I0 (ISBN 9789089642448 ) 
Peter Scholten

Dutch Research-Policy Dialogues in Comparative Perspective 2OII (ISBN 9789089642844 )

Blanca Garcés-Mascareñas

State Regulation of Labour Migration in Malaysia and Spain: Markets, Citizenship and Rights

2OII (ISBN 9789089642868 )

Albert Kraler, Eleonore Kofman, Martin Kohli, Camille Schmoll, Eds. Gender, Generations and the Family in International Migration 2OII (ISBN 978908964285I)

\section{IMISCOE Reports}

Rainer Bauböck, Ed.

Migration and Citizenship: Legal Status, Rights and Political Participation 2006 (ISBN 978905356888 o)

Michael Jandl, Ed.

Innovative Concepts for Alternative Migration Policies: Ten Innovative Approaches to the Challenges of Migration in the 21st Century 2007 (ISBN 978905356990 o)

Jeroen Doomernik, Michael Jandl, Eds.

Modes of Migration Regulation and Control in Europe 2008 (ISBN 978905356689 3)

Michael Jandl, Christina Hollomey, Sandra Gendera, Anna Stepien, Veronika Bilger

Migration and Irregular Work In Austria: A Case Study of the Structure and Dynamics of Irregular Foreign Employment in Europe at the Beginning of the $21^{\text {st }}$ Century 2008 (ISBN 9789089640536 )

Heinz Fassmann, Ursula Reeger, Wiebke Sievers, Eds. Statistics and Reality: Concepts and Measurements of Migration in Europe 2009 (ISBN 9789089640529 )

Karen Kraal, Judith Roosblad, John Wrench, Eds.

Equal Opportunities and Ethnic Inequality in European Labour Markets: Discrimination, Gender and Policies of Diversity 2009 (ISBN 978908964 I26 7) 
Tiziana Caponio, Maren Borkert, Eds.

The Local Dimension of Migration Policymaking

20I0 (ISBN 9789089642325 )

\section{IMISCOE Dissertations}

Panos Arion Hatziprokopiou

Globalisation, Migration and Socio-Economic Change in Contemporary

Greece: Processes of Social Incorporation of Balkan Immigrants in Thessaloniki 2006 (ISBN 9789053568736 )

Floris Vermeulen

The Immigrant Organising Process: Turkish Organisations in Amsterdam and Berlin and Surinamese Organisations in Amsterdam, 1960-2000 2006 (ISBN 978905356875 ㅇ)

Anastasia Christou

Narratives of Place, Culture and Identity: Second-Generation

Greek-Americans Return 'Home'

2006 (ISBN 978905356878 I)

Katja Rušinović

Dynamic Entrepreneurship: First and Second-Generation Immigrant Entrepreneurs in Dutch Cities

2006 (ISBN 9789053569726 )

Ilse van Liempt

Navigating Borders: Inside Perspectives on the Process of Human Smuggling into the Netherlands

2007 (ISBN 9789053569306 )

Myriam Cherti

Paradoxes of Social Capital: A Multi-Generational Study of Moroccans in London

2008 (ISBN 978905356032 7)

Marc Helbling

Practising Citizenship and Heterogeneous Nationhood: Naturalisations in Swiss Municipalities

2008 (ISBN 978908964034 5) 
Jérôme Jamin

L'imaginaire du complot: Discours d'extrême droite en France et aux Etats-Unis

2009 (ISBN 978908964048 2)

Inge Van Nieuwenhuyze

Getting by in Europe's Urban Labour Markets: Senegambian Migrants'

Strategies for Survival, Documentation and Mobility

2009 (ISBN 9789089640505 )

Nayla Moukarbel

Sri Lankan Housemaids in Lebanon: A Case of 'Symbolic Violence' and 'Every Day Forms of Resistance'

2009 (ISBN 978908964 O5I 2)

John Davies

'My Name Is Not Natasha': How Albanian Women in France Use

Trafficking to Overcome Social Exclusion (1998-2001)

2009 (ISBN 978905356707 4)

Dennis Broeders

Breaking Down Anonymity: Digital Surveillance of Irregular Migrants in Germany and the Netherlands

2009 (ISBN 978908964 I59 5)

Arjen Leerkes

Illegal Residence and Public Safety in the Netherlands

2009 (ISBN 978908964049 9)

Jennifer Leigh McGarrigle

Understanding Processes of Ethnic Concentration and Dispersal:

South Asian Residential Preferences in Glasgow

2009 (ISBN 978905356 67I 8)

João Sardinha

Immigrant Associations, Integration and Identity: Angolan, Brazilian

and Eastern European Communities in Portugal

2009 (ISBN 9789089640369 )

Elaine Bauer

The Creolisation of London Kinship: Mixed African-Caribbean and White British Extended Families, 1950-2003

20I0 (ISBN 978908964235 6) 
Nahikari Irastorza

Born Entrepreneurs? Immigrant Self-Employment in Spain

20I0 (ISBN 978908964243 I)

Marta Kindler

A Risky Business? Ukrainian Migrant Women in Warsaw's Domestic Work Sector

2OII (ISBN 978908964 3278)

IMISCOE Textbooks

Marco Martiniello, Jan Rath, Eds.

Selected Studies in International Migration and Immigrant Incorporation 20I0 (ISBN 978908964 I60I) 
Second-generation Russians face two major integration challenges in the Estonian cities of Tallinn and Kohtla-Järve. They are segregated from an Estonian language society, mostly due to the policies and social processes of the former Soviet Union. And, compared to their peers, they encounter emerging disparity in social and economic opportunities. Such inequality comes largely as the result of newly formed, post-independence institutions, and it incites protest among young Russians. With a looming potential to escalate into large-scale conflict, as exemplified by the Bronze Soldier crisis in April 2007, it is crucial to learn more about this dissatisfaction and the generation in whom it is found. As the second country report of The Integration of the European Second Generation project known as TIES, this volume sheds light on how various factors can impact integration and how actors use socio-economic and cultural resources in their adaptation process in Estonia - and beyond.

Raivo Vetik and Jelena Helemäe are both senior researchers at Tallinn University, Institute of International and Social Studies, Estonia.

"For the first time such extensive empirical material is presented about the controversial social - and political consequences of the post-independence minority policies in Estonia. A good study of how ethnicity affects social equality."

Dr. Priit Järve, Non-Resident Senior Research Associate European Centre for Minority Issues, Flensburg, Germany

"This book is a vivid account of the experiences of Russian youth in overcoming integration barriers in various dimensions of social life in Estonia. It is recommended to all those interested in ethnic and migration studies."

Irena Kogan, Project Director The Mannheim Centre for European Social Research, Germany

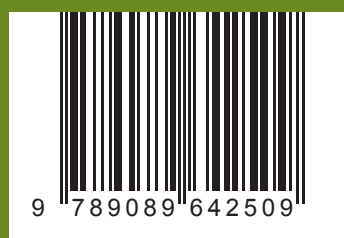

ISBN 9789089642509 